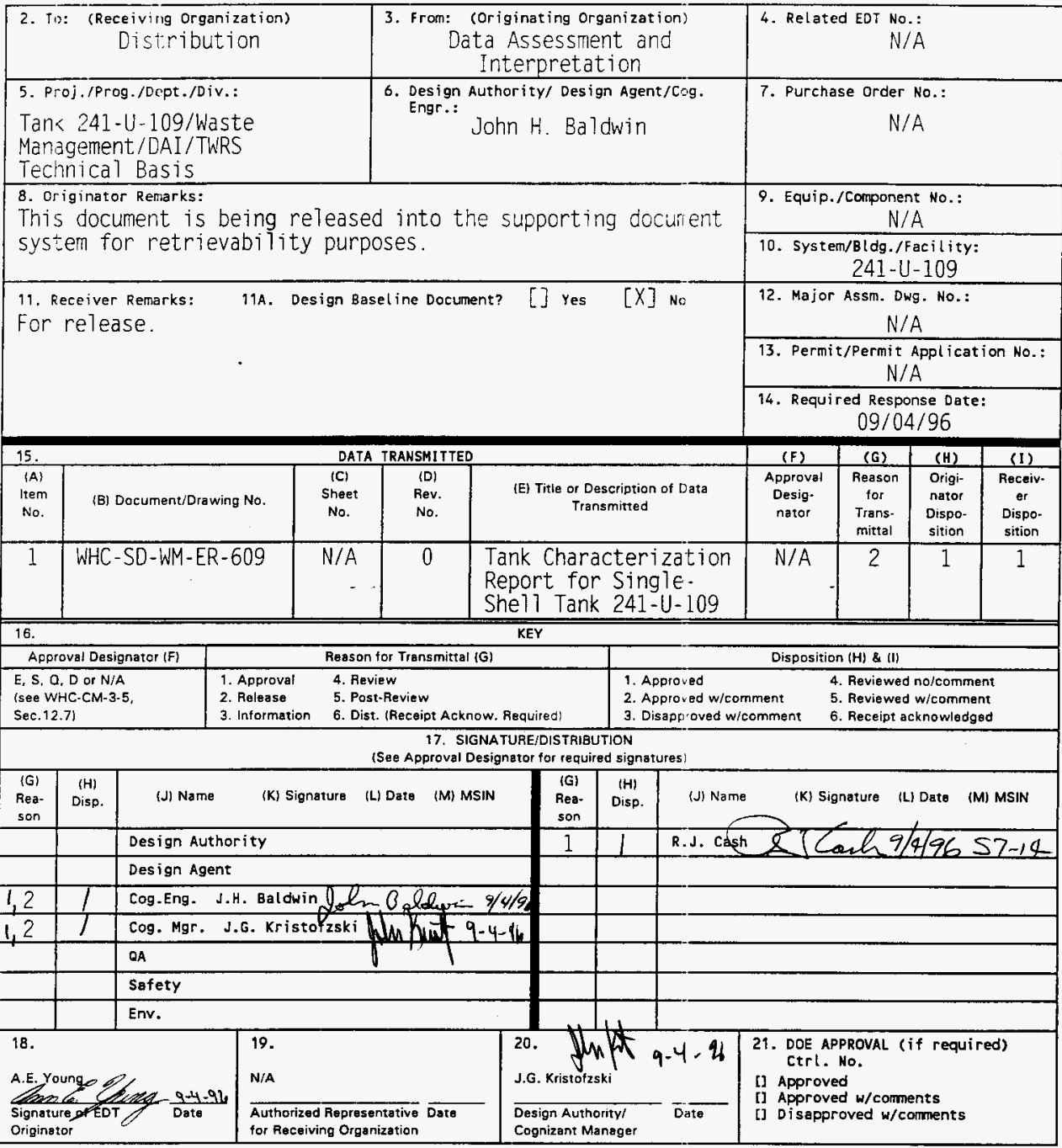

BD-7400-172-2(05/96) GEF097 


\title{
Tank Characterization Report for Single-Shell Tank 241-U-109
}

\author{
John $\mathrm{H}$. Baldwin
}

Westinghouse Hanford Company, Richland, WA 99352

U.S. Department of Energy Contract DE-AC06-87RL.10930

$\begin{array}{lll}\text { EDT/ECN: } & \text { EDT-617522 } & \text { UC: } 2070 \\ \text { Org Code: } & 79400 & \text { Charge Code: N4G4D } \\ \text { B\&R Code: } & \text { EW } 3120074 & \text { Tota1 Pages: } 154\end{array}$

Key Words: Tank Characterization Report, TCR. Single-She11, SST, Tank 241-U-109. Tank U-109, U-109. U Farm. M-44-09.

Abstract: This document summarizes the information on the historical uses, present status, and the sampling and analysis results of waste stored in tank 241-U-109. This report supports the requirements of TriParty Agreement Mi lestone M-44-09.

TRADEMARK DISCLAIMER. Reference herein to any specific comercial product, process, or service by trade name, trademark, manufacturer, or otherwise, does not necessarily constitute or imply its endorsement, recommendation, or favoring by the United States Goverrment or any agency thereof or i ts contractors or subcontractors.

Printed in the United States of America. To obtain copies of this document, contact: WHC/BCS Document Control Services, P.O. Box 1970, Mailstop H6-08, Richland WA 99352, Phone (509) 372-2420; Fax (509) 376-4989.
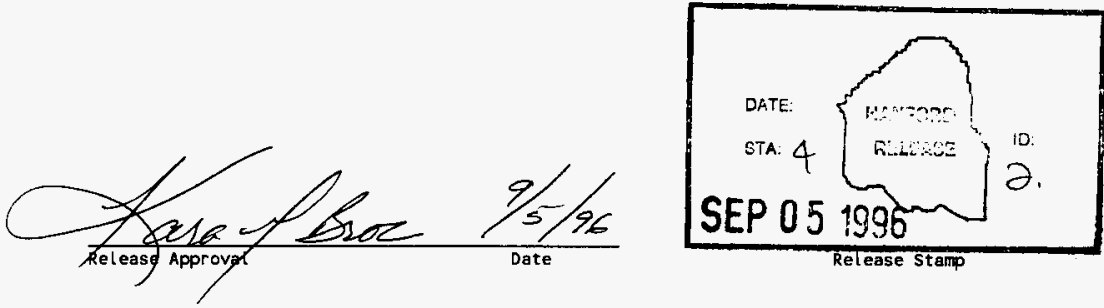

\section{Approved for Public Release}




\title{
Tank Characterization Report for Single-Shell Tank 241-U-109
}

\author{
J. H. Baldwin
}

Westinghouse Hanford Company

R. H. Stephens

Los Alamos Technical Associates

Date Published

September 1996

Prepared for the U.S. Department of Energy

Assistant Secretary for Environmental Management

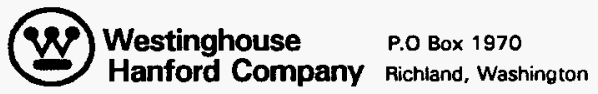

Management and Operations Contractor for the

U.S. Department of Energy under Contrect DE-AC06-87RL10930

Approved for public release; distribution is unlimited 


\section{EXECUTIVE SUMMARY}

This characterization report summarizes the available information on the historical uses, current status, and sampling and analysis results of waste contained in underground storage tank 241-U-109. This report supports the requirements of the Hanford Federal Facility Agreement and Consent Order, Milestone M-44-09 (Ecology et al. 1996).

Tank 241-U-109 is one of 12 single-shell tanks located in the Hanford Site 200 West Area U Tank Farm. It is the third in a cascade series of three tanks beginning with tanks 241-U-107 and -108. Tank 241-U-109 went into service in March 1949 by receiving metal waste from the bismuth phosphate process, and was full by the third quarter of 1949 . Most of this waste was removed by the second quarter of 1955 as part of uranium recovery operations, leaving only a heel. In the last two quarters of 1956, reduction-oxidation (REDOX) supernatant waste was received. Additional transfers of supernatant waste into and out of the tank occurred over the next several years. In the last quarter of 1975, tank 241-U-109 received 242-S Evaporator bottoms waste. Between the first quarter of 1976 and the second quarter of 1977 , residual liquor was both received and pumped out of the tank. Tank 241-U-109 was deactivated in March 1978 and partially interim-isolated in December 1982.

A description of tank 241-U-109 and its status are presented in Table ES-1, and a plan view schematic and profile are provided in Figure ES-1. The tank has an operating capacity of $2,010 \mathrm{~kL}(530 \mathrm{kgal})$, and presently contains an estimated $1,753 \mathrm{~kL}$ (463 kgal) of 
non-complexed waste. Of this total volume, $72 \mathrm{~kL}$ (19 kgal) are estimated to be supernatant, $182 \mathrm{~kL}$ (48 kgal) are estimated to be sludge, and 1,499 kL (396 kgal) are predicted to be saltcake. The sludge and saltcake contain an estimated $617 \mathrm{~kL}(163 \mathrm{kgal})$ of drainable interstitial liquid (Hanlon 1996). 
Table ES-1. Description and Status of Tank 241-U-109.

\begin{tabular}{|c|c|}
\hline \multicolumn{2}{|l|}{ 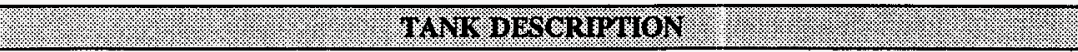 } \\
\hline Type & Single-shell \\
\hline Constructed & $1943-1944$ \\
\hline In-service & March 1949 \\
\hline Diameter & $22.9 \mathrm{~m}(75.0 \mathrm{ft})$ \\
\hline Operating depth & $5.2 \mathrm{~m}(17 \mathrm{ft})$ \\
\hline Capacity & $2,010 \mathrm{~kL}(530 \mathrm{kgal})$ \\
\hline Bottom shape & Dish \\
\hline Ventilation & Passive \\
\hline (.) & (1. \\
\hline Waste classification & Non-complexed \\
\hline Total waste volume & $1,753 \mathrm{~kL}(463 \mathrm{kgal})$ \\
\hline Sludge volume & $182 \mathrm{~kL}$ (48 kgal) \\
\hline Saltcake volume & $1,499 \mathrm{~kL}(396 \mathrm{kgal})$ \\
\hline Supernatant volume & $72 \mathrm{~kL}(19 \mathrm{kgal})$ \\
\hline Waste surface level (June 23, 1996) & $449 \mathrm{~cm}$ (176.7 in.) \\
\hline Temperature (July 1987 to June 1996) & $5.8^{\circ} \mathrm{C}\left(60.5^{\circ} \mathrm{F}\right)$ to $36^{\circ} \mathrm{C}\left(96^{\circ} \mathrm{F}\right)$ \\
\hline Integrity & Sound \\
\hline Watch List & Flammable gases \\
\hline 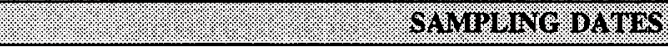 & 2. \\
\hline Vapor sampling & August 1995 \\
\hline $\begin{array}{l}\text { Push mode core samples and tank headspace } \\
\text { flammability }\end{array}$ & December 1995 to January 1996 \\
\hline 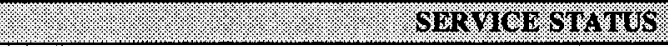 & 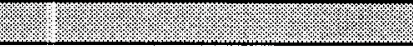 \\
\hline Deactivated & March 1978 \\
\hline Partially interim isolated & December 1982 \\
\hline
\end{tabular}


Figure ES-1. Profile of Tank 241-U-109.

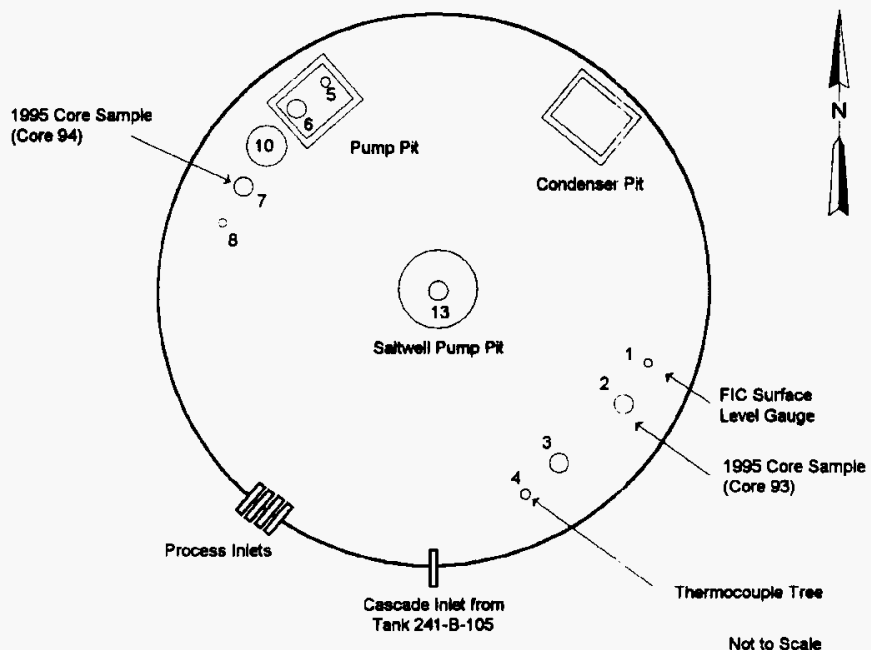

Not to Scale

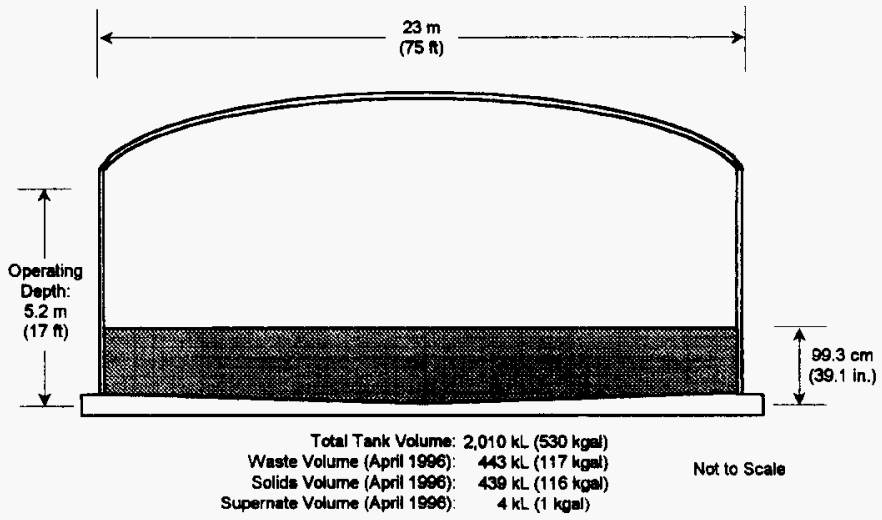


This report summarizes the collection and analysis of three push mode core samples using a rotary core truck, which were acquired in December 1995 and January 1996, and reported in the Final Report for Tank 241-U-109, Rotary and Push Mode Cores 123, 124, and 128 (Baldwin 1996a). Cores 123, 124, and 128 were obtained from risers 2, 19, and 7, respectively. The sampling event was performed to satisfy the requirements listed in the Tank Safety Screening Data Quality Objective (Dukelow et al. 1995), the Data Quality Objective to Support Resolution of the Organic Complexant Safety Issue (Turner et al. 1995), the Test Plan for Samples From Hanford Waste Tanks 241-BY-103, BY-104, BY-105, BY-106, $B Y-108, B Y-110, T Y-103, U-105, U-107, U-108$, and $U-109$ (Meacham 1995), and the Historical Model Evaluation Data Requirements (Simpson and McCain 1995). The sampling and analyses were performed in accordance with the Tank 241-U-109 Push Core Sampling and Analysis Plan (Baldwin 1996b). This report also summarizes the results from the August 1995 vapor sampling event. The headspace gas and vapor samples were collected and analyzed to satisfy Data Quality Objectives for Generic In-Tank Health and Safety Vapors Resolution (Osborne et al. 1995).

The safety screening data quality objective (DQO) requires analyses for fuel content using differential scanning calorimetry (DSC), weight percent water by thermogravimetric analysis (TGA), total alpha activity through alpha proportional counting, and bulk density measurement by centrifugation. The safety screening DQO also requires a determination of the flammability of the tank headspace gases. To satisfy this requirement, vapor samples were taken before core sampling, and the flammability was measured as a percentage of the lower flammability limit (LFL) using a combustible gas meter. The organic complexant 
safety DQO and the organic safety test plan also require analyses for fuel content and weight percent water, as well as analyses for total organic carbon (TOC) to evaluate its contribution to the total fuel content. The historical model evaluation DQO requires analyses for several analytes, including the key analytes sodium, aluminum, chromium, carbonate, nitrate, and weight percent water. Finally, the headspace vapor samples were collected and analyzed to characterize the vapors present in the tank headspace and to support safety evaluations and tank farm operations.

To evaluate tank safety, comparisons were made between the analytical results and the decision criteria thresholds defined in the safety screening and organic complexant safety DQOs, and the organic safety test plan. All results given below for DSC and TOC are on a dry weight basis. No exothermic reactions with a change in enthalpy greater than $301.9 \mathrm{~J} / \mathrm{g}$ were observed in any of the samples, as compared with the safety screening and organic complexant safety DQO decision criteria threshold of $480 \mathrm{~J} / \mathrm{g}$, and the organic safety test plan decision threshold of $1,200 \mathrm{~J} / \mathrm{g}$. Although one of the one-sided 95 percent confidence interval on the mean upper limits was $493.4 \mathrm{~J} / \mathrm{g}$, this was attributed to variability in the data (Baldwin 1996a). All TOC results were below the decision thresholds of $30,000 \mu \mathrm{g} \mathrm{C} / \mathrm{g}$ for the organic complexant safety DQO and $45,000 \mu \mathrm{g} \mathrm{C} / \mathrm{g}$ for the organic safety test plan. The overall mean result was $4,720 \mu \mathrm{g} \mathrm{C} / \mathrm{g}$, the highest segment sample mean was $15,400 \mu \mathrm{g} \mathrm{C} / \mathrm{g}$, and the largest upper limit to one-sided 95 percent confidence interval on the mean was $18,600 \mu \mathrm{g} \mathrm{C} / \mathrm{g}$. All total alpha activity values were at least two orders of magnitude below their safety screening thresholds. The highest sample mean for total alpha activity was $0.150 \mu \mathrm{Ci} / \mathrm{g}$, the overall mean was $0.0371 \mu \mathrm{Ci} / \mathrm{g}$, and the largest 95 percent confidence 
interval upper limit was $0.156 \mu \mathrm{Ci} / \mathrm{g}$. Finally, although tank $241-\mathrm{U}-109$ is on the Flammable Gas Watch List, the concentration of flammable gases in the tank headspace was measured at a maximum of 5 percent of the LFL, well below the decision threshold of 25 percent of the LFL.

The estimated tank heat load based on the analytical results of ${ }^{137} \mathrm{Cs}$ and ${ }^{89 / 90} \mathrm{Sr}$ was $1,880 \mathrm{~W}$ $(6,420 \mathrm{Btu} / \mathrm{hr}$ ). Additional predictions include the Historical Tank Content Estimate (HTCE) of $4,120 \mathrm{~W}(14,100 \mathrm{Btu} / \mathrm{hr})$, and the estimate by Kummerer (1994) of $1,720 \mathrm{~W}$ $(5,865 \mathrm{Btu} / \mathrm{hr})$. All three estimates were below the $11,700 \mathrm{~W}(40,000 \mathrm{Btu} / \mathrm{hr})$ high-heat threshold (Bergmann 1991). The most recent tank temperature information available indicated that between July 1987 and June 1996 , the mean temperature was $26.8{ }^{\circ} \mathrm{C}$ $\left(80.3^{\circ} \mathrm{F}\right)$, with a minimum of $15.8^{\circ} \mathrm{C}\left(60.5^{\circ} \mathrm{F}\right)$, and a maximum of $36^{\circ} \mathrm{C}\left(96^{\circ} \mathrm{F}\right)$. Since the tank exhibits an upper temperature limit, it is concluded that any heat generated from radioactive sources throughout the year is dissipated.

Based on the comparison of the analytical results to the decision criteria thresholds of the safety screening and organic complexant safety DQOs and the organic safety test plan, the tank is considered safe.

The historical model evaluation DQO (Simpson and McCain 1995) attempts to verify the presence of a particular waste type by identifying several key analytes in the tank waste and then comparing their concentrations to predicted levels. Two waste types were expected to be present in tank 241-U-109 in substantial quantities: SMMS2 saltslurry and SMMS1 
saltcake. The results of this comparison indicated that the key analytes met the criterion of $\geq 10$ percent of the concentration level predicted in the historical DQO. The results indicate that the predicted waste types are present.

Hydrostatic head fluid (HHF) was used during the core sampling operations. Evaluation of the tracer indicated significant contamination (over 50 percent) occurred in segment 3 of core 124. Thus, all drainable liquid data and the solids weight percent water result from this segment were considered unusable and were not factored into calculation of the overall tank means, or used in any other evaluations. Intrusion by HHF was also noted in segment 5 of core 128. However, because this intrusion was not considered significant and the weight percent water data were corrected, the data were used for this segment.

A number of observations can be made concerning this tank.

1. Although tank 241-U-109 is on the Flammable Gas Watch List, the flammable gas concentration in the headspace is well below the threshold and is not a cause for concern.

2. The metal waste heel has a level of uranium that exceeds the value predicted from the transfer history.

3. The aluminum in the waste is mostly soluble in water. This agrees with the process history. 
Table ES-2 provides concentration and inventory estimates for the most prevalent analytes, based on the 1995/1996 core sampling analyses.

Table ES-2. Chemical Data Summary for Tank 241-U-109.1

\begin{tabular}{|c|c|c|c|}
\hline 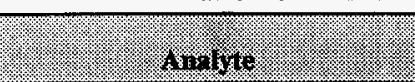 & Pritall iledin & 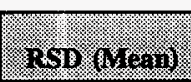 & $\begin{array}{l}\text { Projected } \\
\text { Inverion }\end{array}$ \\
\hline MITALS & (2) & (V. & (1) \\
\hline Aluminum & 19,700 & 32.6 & 57,700 \\
\hline Chromium & 3,690 & 14.1 & $10, \overline{800}$ \\
\hline Sodium & $2.21 \mathrm{E}+05$ & 3.0 & $6.47 \mathrm{E}+05$ \\
\hline Mrons: & gigg & 18 & $\sqrt{1}=8$ \\
\hline Nitrate & $3.08 \mathrm{E}+05$ & 12.8 & $9.02 E+05$ \\
\hline FFDTONUTOWES & Profog & 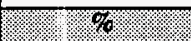 & (1): \\
\hline Total alpha & 0.0371 & 20.9 & 109 \\
\hline Total beta & 126 & 12.1 & $3.69 \mathrm{E}+05$ \\
\hline${ }^{137} \mathrm{Cs}$ & 112 & 9.8 & $3.28 \mathrm{E}+05$ \\
\hline${ }^{90} \mathrm{Sr}$ & 6.89 & 15.4 & 20,200 \\
\hline CARBOT & 48 Ch: & (2.) & 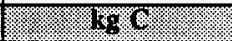 \\
\hline Total inorganic carbon & 7,550 & 12.0 & 22,100 \\
\hline Total organic carbon & 3,600 & 7.8 & 10,500 \\
\hline PTIYSTCAI PROPARTIES & 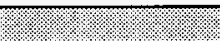 & 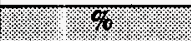 & (16g \\
\hline Weight percent water & 23.7 & 13.6 & $6.94 \mathrm{E}+05$ \\
\hline Density $(\mathrm{g} / \mathrm{mL})$ & 1.67 & 1.6 & $n / a$ \\
\hline
\end{tabular}

Notes:

$\mathfrak{n} / \mathbf{a}=$ not applicable

'Baldwin 1996a)

${ }^{2}$ The projected inventory is based on an estimated waste volume of $1,753 \mathrm{~kL}$ (463 kgal)

(Hanlon 1996) and a density of $1.67 \mathrm{~g} / \mathrm{mL}$. 
WHC-SD-WM-ER-609 Rev. 0

This page intentionally left blank. 


\section{CONTENTS}

1.0 INTRODUCTION $\ldots \ldots \ldots \ldots \ldots \ldots \ldots \ldots \ldots \ldots \ldots \ldots \ldots \ldots \ldots \ldots \ldots .1$

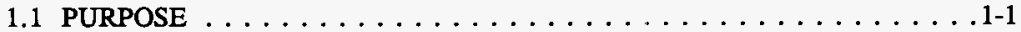

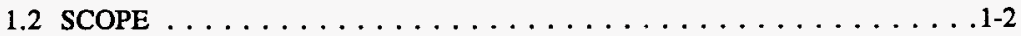

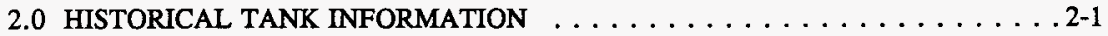

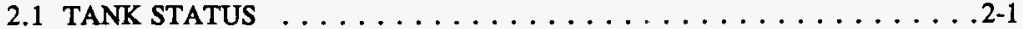

2.2 TANK DESIGN AND BACKGROUND $\ldots \ldots \ldots \ldots \ldots \ldots \ldots \ldots .2$

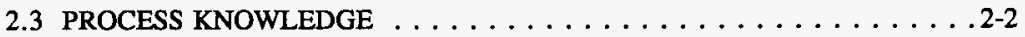

2.3.1 Waste Transfer History . . . . . . . . . . . . 2-6

2.3.2 Historical Estimation of Tank Contents . . . . . . . 2-6

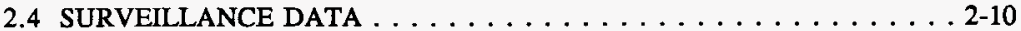

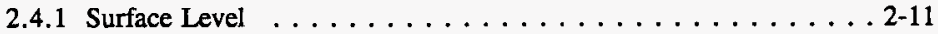

2.4.2 Internal Tank Temperatures . . . . . . . . . . . 2-11

2.4.3 Tank 241-U-109 Photographs . . . . . . . . . . . . 2-14

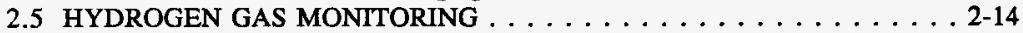

3.0 TANK SAMPLING OVERVIEW $\ldots \ldots \ldots \ldots \ldots \ldots \ldots \ldots \ldots \ldots \ldots \ldots \ldots$ 3-1

3.1 DESCRIPTION OF SAMPLING EVENT $\ldots \ldots \ldots \ldots \ldots \ldots \ldots \ldots .2$

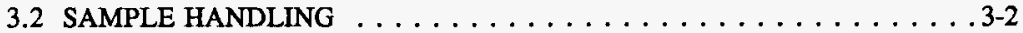

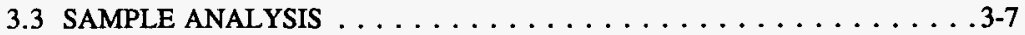

3.4 DESCRIPTION OF THE VAPOR SAMPLING EVENT (1995) $\ldots \ldots \ldots 3-15$

3.5 DESCRIPTION OF HISTORICAL SAMPLING EVENT . . . . . . . 3-15

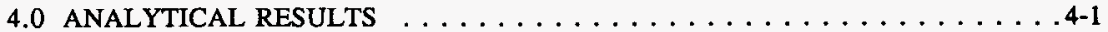

4.1 DATA PRESENTATION $\ldots \ldots \ldots \ldots \ldots \ldots \ldots \ldots \ldots$. . $\ldots \ldots \ldots$

4.1.1 Chemical Data Summary . . . . . . . . . . . . . 4-1

4.1.2 Physical Data Summary . . . . . . . . . . . . . 4-2

4.1.3 Headspace Flammability Screening Results . . . . . . . . . . 4-4

4.1.4 Hydrostatic Head Fluid Contamination Check . . . . . . . . . 4-6

4.2 DATA SUMMARY OF 1995 VAPOR SAMPLING . . . . . . . . . 4-6

5.0 INTERPRETATION OF CHARACTERIZATION RESULTS $\ldots \ldots \ldots \ldots \ldots$ 5-1

5.1 ASSESSMENT OF SAMPLING AND ANALYTICAL RESULTS $\ldots \ldots 5-1$

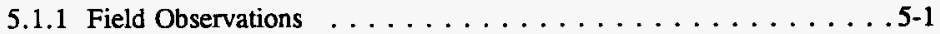

5.1 .2 Quality Control Assessment . . . . . . . . . . . 5-1

5.1.3 Data Consistency Checks ... . . . . . . . . . . . 5-2

5.2 COMPARISON OF HISTORICAL WITH ANALYTICAL RESULTS $\ldots$. 5-3

5.3 TANK WASTE PROFILE $\ldots \ldots \ldots \ldots \ldots \ldots \ldots \ldots \ldots$ 


\section{CONTENTS (Continued)}

5.4 COMPARISON OF TRANSFER HISTORY WITH ANALYTICAL RESULTS $\ldots \ldots \ldots \ldots \ldots \ldots \ldots \ldots$

5.5 EVALUATION OF PROGRAM REQUIREMENTS $\ldots \ldots \ldots \ldots \ldots$ 5-6

5.5 .1 Safety Evaluation $\ldots \ldots \ldots \ldots \ldots \ldots \ldots \ldots \ldots$

5.5.2 Historical Model Evaluation . . . . . . . . . . 5-11

6.0 CONCLUSIONS AND RECOMMENDATIONS $\ldots \ldots \ldots \ldots \ldots \ldots$ 6-1

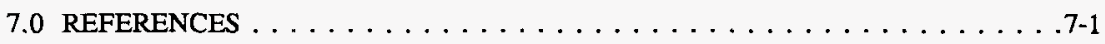

\section{APPENDIXES}

A ANALYTICAL RESULTS FROM 1995/1996 CORE SAMPLING

OF SINGLE-SHELL TANK $241-\mathrm{U}-109 \ldots \ldots \ldots \ldots \ldots \ldots \ldots \ldots$ A-1

B ANALYTICAL RESULTS OF HYDROSTATIC HEAD FLUID

CONTAMINATION CHECK FOR SINGLE-SHELL TANK $241-U-109 \ldots \ldots$ B-1

C ANALYTICAL RESULTS FROM HISTORICAL SAMPLING

EVENTS FOR SINGLE-SHELL TANK $241-U-109 \ldots \ldots \ldots \ldots \ldots \ldots$ C-1 


\section{LIST OF FIGURES}

2-1. Riser Configuration for Tank 241-U-109. . . . . . . . . . . 2-4

2-2. Tank 241-U-109 Cross-Section. . . . . . . . . . . . . 2-5

2-3. Tank Layer Model for Tank 241-U-109. . . . . . . . . . . . . . 2-8

2-4. Tank 241-U-109 Level History. . . . . . . . . . . . . . . . 2-12

2-5. Tank 241-U-109 Weekly High Temperature Plot. . . . . . . . . . . . 2-13

2-6. Tank 241-U-109 1988 Photographic Montage. . . . . . . . . . . . . . . 2-15

\section{LIST OF TABLES}

2-1. Estimated Tank Contents $\ldots \ldots \ldots \ldots \ldots \ldots \ldots \ldots \ldots \ldots \ldots \ldots \ldots \ldots$ 2-1

2-2. Tank 241-U-109 Risers $\ldots \ldots \ldots \ldots \ldots \ldots \ldots \ldots \ldots \ldots \ldots . . \ldots \ldots$

2-3. Summary of Tank $241-\mathrm{U}-109$ Waste Received History $\ldots \ldots \ldots \ldots \ldots$. . . . . .

2-4. Tank 241-U-109 Historical Tank Content Estimate. . . . . . . . . . . . . . 2-9

3-1. Integrated Data Quality Objective Requirements for Tank 241-U-109 . . . . . . 3-2

3-2. Subsampling Scheme and Sample Description . . . . . . . . . 3-3

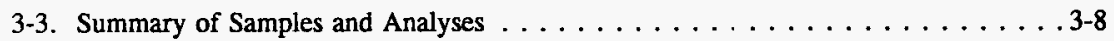

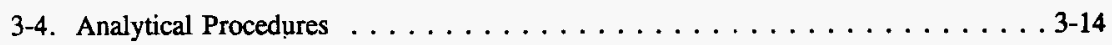

4-1. Analytical Data Presentation Tables . . . . . . . . . . . . 4-1

4-2. Chemical Data Summary for Tank $241-U-109 \ldots \ldots \ldots \ldots$. . . . . . . .

4-3. Exothermic DSC Results and 95 Percent Confidence Interval Upper Limits . . . . 4-5

4-4. Summary Results of Samples to Characterize the Headspace

of Tank 241-U-109 on August $10,1995 \ldots \ldots \ldots \ldots \ldots \ldots \ldots$ 
WHC-SD-WM-ER-609 Rev. 0

\section{LIST OF TABLES (Continued)}

5-1. Comparison of Total Beta Activity with the Sum of ${ }^{89 / 90} \mathrm{Sr}$ and ${ }^{137} \mathrm{Cs}$ Activities . . . 5-3

5-2. Comparison of HTCE with 1995/1996 Analytical Results

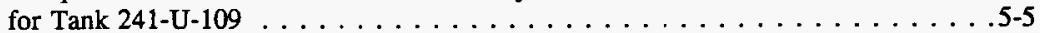

5-3. Decision Variables and Criteria for the Safety Screening and Organic Complexant Safety Data Quality Objectives

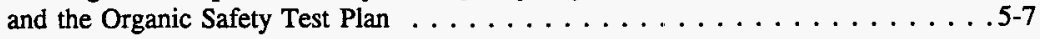

5-4. Comparison of DSC Analytical Results with TOC Energy Equivalents (Dry Weight Basis) $\ldots \ldots \ldots \ldots \ldots \ldots$. . . . . . .

5-5. Tank 241-U-109 Estimated Heat Load . . . . . . . . . . . . . . 5-11 


\section{LIST OF TERMS}

\begin{tabular}{ll} 
ANOVA & analysis of variance \\
Btu/hr & British thermal units per hour \\
Ci & curies \\
Ci/L & curies per liter \\
cm & centimeters \\
CWR1 & REDOX cladding waste \\
DL & drainable liquid \\
DQO & data quality objective \\
DSC & differential scanning calorimetry \\
ft & feet \\
g & grams \\
g/mL & grams per milliliter \\
GEA & gamma energy analysis \\
HDW & Hanford Defined Waste \\
HHF & hydrostatic head fluid \\
HTCE & Historical Tank Content Estimate \\
in. & inches \\
IC & ion chromatography \\
ICP & inductively coupled plasma spectroscopy \\
J/g & joules per gram \\
kg & kilograms \\
kg C & kilograms of carbon \\
kgal & kilogallons \\
kL & kiloliters \\
LFL & lower flammability limit \\
m & meters \\
M & moles per liter \\
MW & metal waste \\
mR/hr & milliroentgens per hour \\
PNNL & Pacific Northwest National Laboratory \\
REDOX & reduction-oxidation \\
QA & quality assurance \\
QC & quality control \\
RPD & relative percent difference \\
RSD & relative standard deviation \\
SACS & Surveillance Analysis Computer System \\
SAP & sampling and analysis plan \\
SHMS & Standard Hydrogen Monitoring System \\
SMMS1 & saltcake \\
SMMS2 & saltslurry \\
TC & thermocouple \\
TGA & thermogravimetric analysis \\
& \\
\hline
\end{tabular}




\section{LIST OF TERMS (Continued)}

TIC

TLM

TOC

$\mathrm{W}$

WHC

WSTRS

wt\%

${ }^{\circ} \mathrm{C}$

${ }^{\circ} \mathrm{F}$

$\mu \mathrm{g} \mathrm{C} / \mathrm{g}$

$\mu \mathrm{g} \mathrm{C} / \mathrm{mL}$

$\mu \mathrm{Ci} / \mathrm{g}$

$\mu \mathrm{Ci} / \mathrm{L}$

$\mu \mathrm{Ci} / \mathrm{mL}$

$\mu \mathrm{g} / \mathrm{g}$

$\mu \mathrm{g} / \mathrm{mL}$

$\Delta \mathrm{H}$ total inorganic carbon

Tank Layer Model

total organic carbon

watts

Westinghouse Hanford Company

Waste Status and Transaction Record Summary

weight percent

degrees Celsius

degrees Fahrenheit

micrograms carbon per gram

micrograms carbon per milliliter

microcuries per gram

microcuries per liter

microcuries per milliliter

micrograms per gram

micrograms per milliliter

enthalpy change 


\subsection{INTRODUCTION}

This tank characterization report presents an overview of single-shell tank 241-U-109 and its waste contents. It provides estimated concentrations and inventories for the waste components based on the latest sampling and analysis activities, in combination with background tank information. The characterization of tank $241-U-109$ is based on the results of three push-mode core samples using a rotary core truck, taken in December 1995 and January 1996. The sampling and analysis event was performed to support the Tank Safety Screening Data Quality Objective (Dukelow et al. 1995), Data Quality Objective to Support Resolution of the Organic Complexant Safety Issue (Turner et al.1995), Historical Model Evaluation Data Requirements (Simpson and McCain 1995), Data Quality Objectives for Generic In-Tank Health and Safety Vapors Resolution (Osborne et al. 1995), and the Test Plan for Samples From Hanford Waste Tanks 241-BY-103, BY-104, BY-105, BY-106, $B Y-108, B Y-110, T Y-103, U-105, U-107, U-108$, and $U-109$ (Meacham 1995). The integrated requirements for analyses and decision criteria thresholds for the three DQOs and the test plan can be found in Tank 241-U-109 Push Core Sampling and Analysis Plan (Baldwin 1996b).

Tank 241-U-109 was removed from service in 1978 and partially interim-isolated in 1982. Consequently, the composition of the waste should not change appreciably until pretreatment and retrieval activities commence. The analyte concentrations reported in this document reflect the best available estimates of the current tank contents based on the analytical data and historical models. This report supports the requirements of the Hanford Federal Facility Agreement and Consent Order, Milestone M-44-09 (Ecology et al. 1996).

\subsection{PURPOSE}

The purpose of this report is to summarize the information about the use and contents of tank 241-U-109. Where possible, this information will be used to assess issues associated with safety, operations, environmental, and process development activities. This report also serves as a reference point for more detailed information concerning tank $241-U-109$. 


\subsection{SCOPE}

In accordance with the requirements specified in Baldwin (1996b), the following analyses were performed: DSC to evaluate fuel level and energetics; TGA to determine moisture content; total alpha activity analysis to evaluate criticality potential; inductively coupled plasma spectroscopy (ICP) for lithium, aluminum, chromium, sodium, and other selected metals; ion chromatography (IC) for bromide, nitrate, and other selected anions; persulfate and acid coulometry for TOC and total inorganic carbon (TIC); gamma energy analysis (GEA) for ${ }^{137} \mathrm{Cs}$; uranium by laser fluorimetry; total beta; total alpha activity; ${ }^{89 / 90} \mathrm{Sr}$; and bulk density. In addition to these analyses conducted on the core samples, the tank headspace was sampled for the presence of flammable gases in accordance with the safety screening DQO. This was especially important for tank $241-U-109$ because it is on the Flammable Gas Watch List.

Prior to the sampling event discussed in this report, vapor samples were taken from the headspace of tank 241-U-109. These samples were analyzed for permanent gases using gas chromatography/thermal conductivity detection, for total non-methane hydrocarbons using cryogenic preconcentration followed by gas chromatography/flame ionization detection, and for volatile organic analytes using cryogenic preconcentration followed by gas chromatography/mass spectrometry. 


\subsection{HISTORICAL TANK INFORMATION}

This section describes tank 241-U-109 based on historical information. The first part details the current condition of the tank. This is followed by discussions of the tank design, transfer history, and process sources that contributed to the tank waste, including an estimate of the current contents based on the process history. Events that may be related to tank safety issues, such as potentially hazardous tank contents or off-normal operating temperatures, are included. The final part summarizes available surveillance data for the tank. Solid and liquid level data are used to determine tank integrity (leaks) and to provide clues to internal activity in the solid layers of the tank. Temperature data are provided to evaluate the heat generating characteristics of the waste.

\subsection{TANK STATUS}

As of March 31, 1996, tank 241-U-109 contained an estimated 1,753 kL (463 kgal) of waste classified as non-complexed (Hanlon 1996). Liquid and solid waste volumes are estimated using a level measurement gauge. The solid waste volume was last updated on November 13, 1977. The amounts of various waste phases in the tank are presented in Table 2-1.

Table 2-1. Estimated Tank Contents.

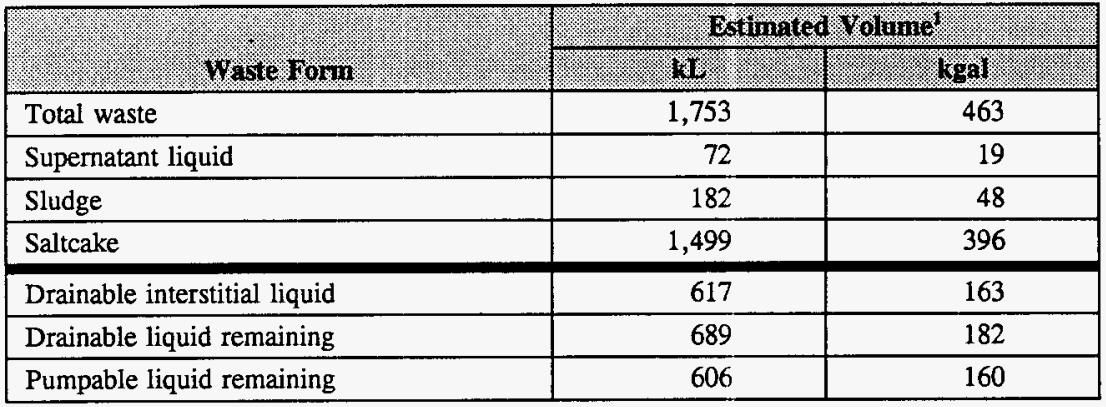

Note:

'For definitions and calculation methods, refer to Appendix C of Hanlon (1996). 
Tank 241-U-109 is out of service, as are all single-shell tanks, and is categorized as sound. The tank is on the Flammable Gas Watch List. The tank is passively ventilated. All monitoring systems were in compliance with documented standards as of March 31, 1996 (Hanlon 1996).

\subsection{TANK DESIGN AND BACKGROUND}

The 241-U Tank Farm was constructed during 1943 and 1944 in the 200 West Area. The farm contains twelve 100 -series tanks and four 200 -series tanks. The 100 -series tanks have a capacity of $2,010 \mathrm{~kL}(530 \mathrm{kgal})$, a diameter of $22.9 \mathrm{~m}(75.0 \mathrm{ft})$, and an operating depth of

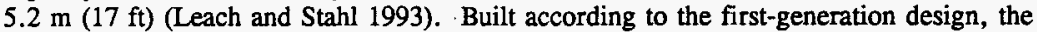
241-U Tank Farm was designed for nonboiling waste with a maximum fluid temperature of $104^{\circ} \mathrm{C}\left(220^{\circ} \mathrm{F}\right)$. A cascade overflow line $7.5 \mathrm{~cm}(3 \mathrm{in}$.) in diameter connects $241-\mathrm{U}-109$ as the third in a cascade series of three tanks, beginning with tanks 241-U-107 and -108. Each tank in the cascade series is set $1 \mathrm{ft}$ lower in elevation from the preceding tank. The cascade overflow height is approximately $4.9 \mathrm{~m}$ (16 ft) from the tank bottom and $610 \mathrm{~mm}(2 \mathrm{ft}$ ) below the top of the steel liner.

The tank has a dished bottom with a $1.2 \mathrm{~m}$ (4 ft) radius knuckle. Tank 241-U-109 was designed with a primary mild steel liner (ASTM A283 Grade C) and a concrete dome with various risers. The tank is set on a reinforced concrete foundation. The tank and foundation were waterproofed by a coating of tar covered by a three-ply, asphalt-impregnated waterproofing fabric. The waterproofing was protected by welded wire-reinforced gunite. Two coats of primer were sprayed on all exposed interior tank surfaces (Rogers and Daniels 1944). The tank ceiling dome was covered with three applications of magnesium zinc fluorosilicate wash. Lead flashing was used to protect the joint where the steel liner meets the concrete dome. Asbestos gaskets were used to seal the risers in the tank dome. This tank was covered with approximately $2.1 \mathrm{~m}(7 \mathrm{ft})$ of overburden.

Tank 241-U-109 has 14 risers according to the drawings and engineering change notices. The risers range in diameter from $10.2 \mathrm{~cm}$ (4 in.) to $1.1 \mathrm{~m}$ (42 in.). Table $2-2$ shows numbers, diameters, and descriptions of the risers and the nozzles. A plan view that depicts the riser configuration is shown as Figure 2-1. Risers 10 and $19,10.2 \mathrm{~cm}$ (4 in.) in diameter, and risers 2 and $7,30.5 \mathrm{~cm}$ (12 in.) in diameter, are available for use (Lipnicki 1995). A tank cross-section showing the approximate waste level, along with a schematic of the tank equipment, is shown in Figure 2-2.

\subsection{PROCESS KNOWLEDGE}

Section 2.3.1 and Table 2-3 present the major transfers in which tank 241-U-109 received waste. Section 2.3 .2 presents an estimate of the tank contents. 
Table 2-2. Tank 241-U-109 Risers. ${ }^{1,2,3}$

\begin{tabular}{|c|c|c|}
\hline $\begin{array}{l}\text { Riser: } \\
\text { Number }\end{array}$ & $\begin{array}{l}\text { Divmeter: } \\
\text { (inil: }\end{array}$ & Bescription and Cominents. \\
\hline 1 & 4 & Thermocouple tree [Bench mark CEO-37531 12/11/86] \\
\hline 2 & 12 & Blind flange \\
\hline 3 & 12 & Sluice nozzle, weather covered \\
\hline 4 & 4 & Recirculation line dip legs, weather covered \\
\hline 5 & 4 & Recirculation line dip legs, weather covered \\
\hline 6 & 12 & Sluice nozzle, weather covered \\
\hline 7 & 12 & B-222 observation port \\
\hline 8 & 4 & ENRAF $^{\text {Surface level gauge }}$ \\
\hline 9 & 4 & B-436 liquid observation well [Bench mark CEO-37531 12/11/86] \\
\hline 10 & 4 & $\begin{array}{l}\text { Breather filter [Standard hydrogen monitor system/breather filter } \\
\text { ECN-W369-021 } 1 / 23 / 95 \text { ] }\end{array}$ \\
\hline 12 & 4 & Saltwell transfer line from tank $241-\mathrm{U}-112$ connected \\
\hline 13 & 12 & Distributor jet \\
\hline 18 & 42 & Sludge pump, weather covered \\
\hline 19 & 4 & Sludge measurement port \\
\hline $\begin{array}{l}\text { Nozzle: } \\
\text { Number } \\
\end{array}$ & $\begin{array}{l}\text { Diameter: } \\
\text { (in) }\end{array}$ & 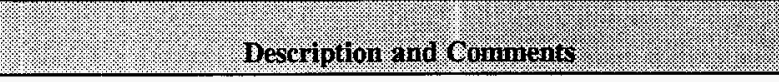 \\
\hline N1 & 3 & Spare, capped \\
\hline N2 & 3 & Spare, capped \\
\hline N3 & 3 & Spare, capped \\
\hline N4 & 3 & Spare, capped \\
\hline N5 & 3 & Inlet overfiow from tank $241-\mathrm{U}-108$ \\
\hline
\end{tabular}

Notes:

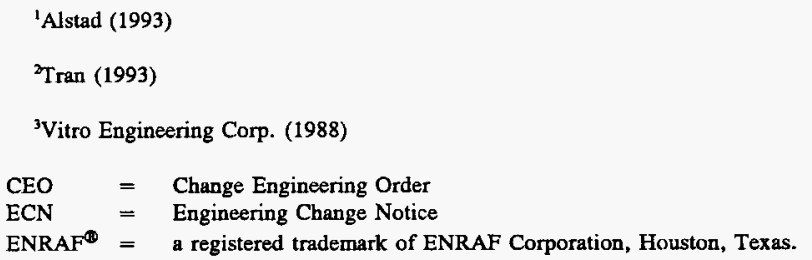


Figure 2-1. Riser Configuration for Tank 241-U-109.

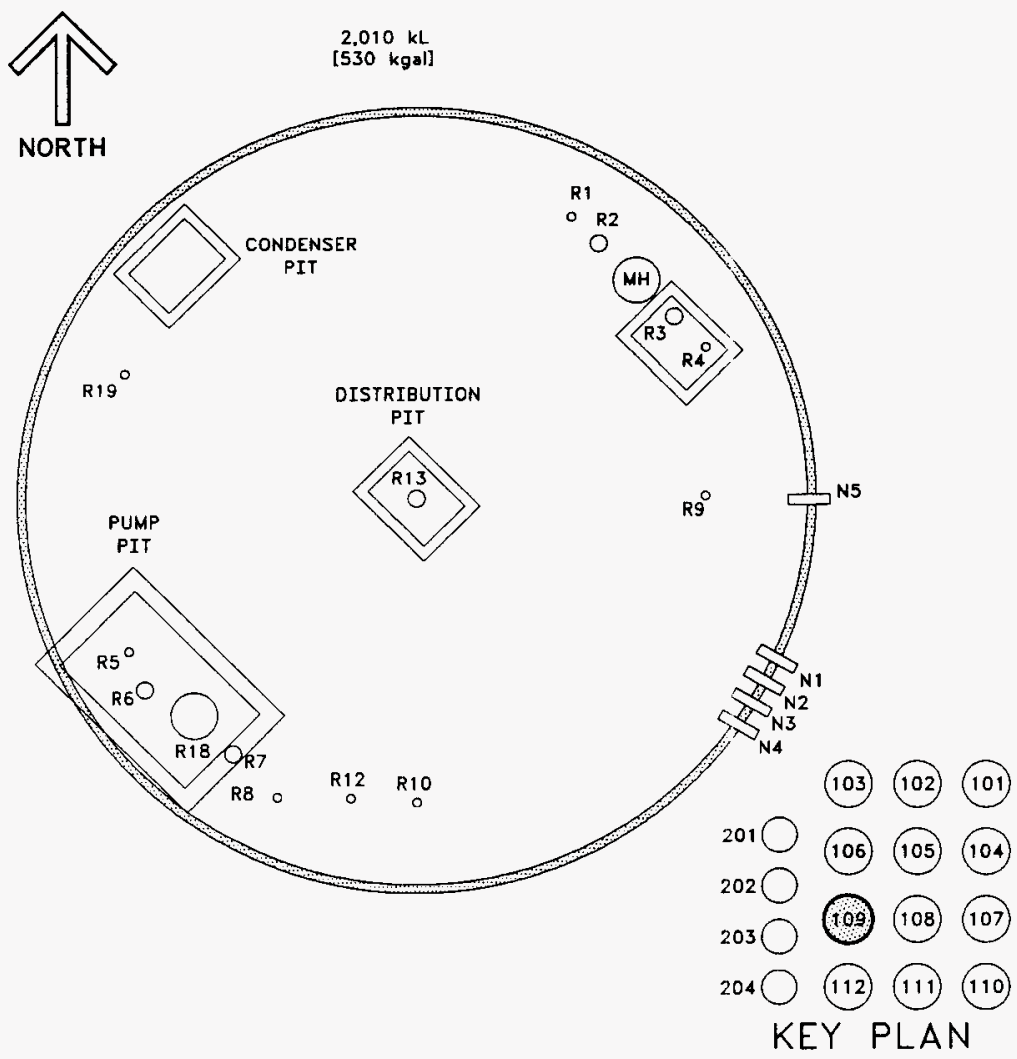


Figure 2-2. Tank 241-U-109 Cross-Section.

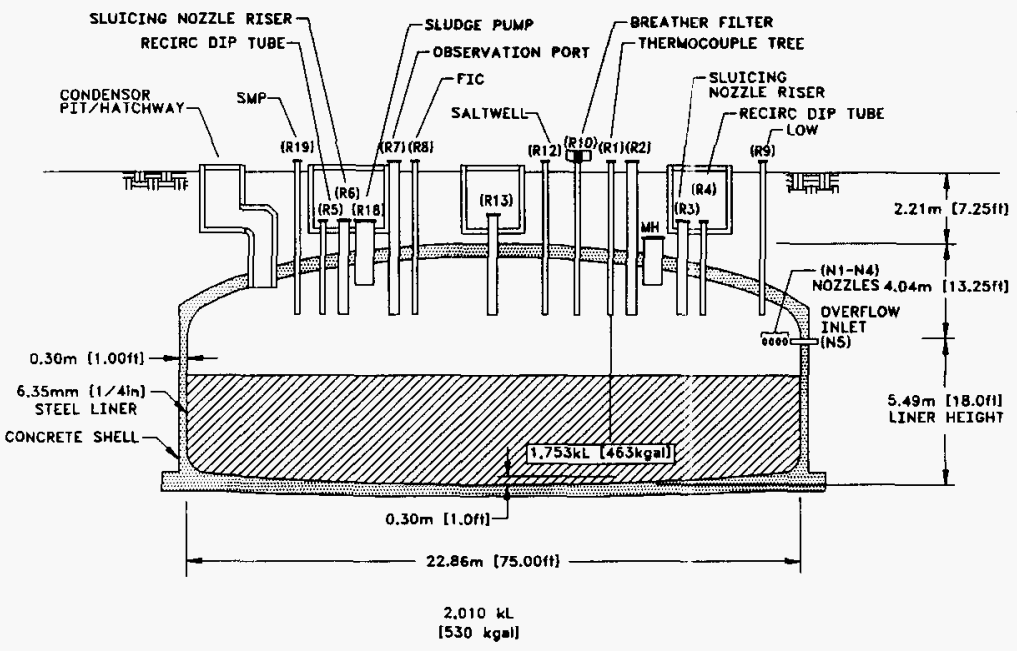




\subsubsection{Waste Transfer History}

Tank 241-U-109 first received metal waste (MW1) from tank 241-U-108 via the cascade line in March 1949, and was full by the third quarter of 1949.

No transfers occurred from the third quarter of 1949 until the second quarter of 1953 , when waste began to be removed for uranium recovery. This removal concluded in the third quarter of 1954, at which time 241-U-109 again received metal waste (MW2) cascaded from 241-U-108. The cascade ended in the fourth quarter of 1954. In the first and second quarters of 1955 , the waste in tank $241-\mathrm{U}-109$ was removed for uranium recovery. The heel remaining in the tank was jet-sluiced in the second quarter of 1956.

In the third and fourth quarters of 1956, tank 241-U-109 received REDOX supernate waste from tank 241-U-110. Aside from occasional additions of water from the 241-U-301 catch tank, no transfers occurred until the first and second quarters of 1969, when waste was sent to tank 241-TX-118. In the fourth quarter of 1969, supernate was received from 241-U-107. No further transfers occurred until the first quarter of 1974, when waste was sent to tank 241-S-110.

From the fourth quarter of 1974 until the third quarter of 1975, small amounts of supernate were received from tank $241-\mathrm{U}-112$. In the fourth quarter of 1975, tank 241-U-109 received 242-S Evaporator bottoms from tank 241-S-102. In the first quarter of 1976 and the second quarter of 1977, residual liquor was sent to tanks 241-S-102 and 241-SY-102, respectively. In the first quarter of 1977 , residual liquor was received from tank 241-S-102.

Tank 241-U-109 was deactivated in the first quarter of 1978, and partially interim-isolated in 1982.

\subsubsection{Historical Estimation of Tank Contents}

The following is an estimate of the contents for tank 241-U-109 based on historical transfer data. The historical data used for the estimate are the Waste Status and Transaction Record Summary for the Southwest Quadrant (WSTRS) (Agnew et al. 1996b), and the Hanford Tank Chemical and Radionuclide Inventories: HDW Model Rev. 3 (Agnew et al. 1996a). The Hanford Defined Waste (HDW) Model Rev. 3 document contains the HDW list, the Tank Layer Model (TLM), and the HTCE. The HTCE predictions have not been validated, and thus should be used with caution.

The WSTRS is a compilation of available waste transfer and volume status data. The HDW provides the assumed typical compositions for Hanford wastes types. In most cases, the available data are incomplete, reducing the reliability of the transfer data and the derived modeling results. The TLM uses the WSTRS data to model the waste deposition processes and, using additional data from the HDW (that may introduce more errors), generates an estimate of the tank contents. Thus, these model predictions are considered estimates that require further evaluation using analytical data. 
Table 2-3. Summary of Tank 241-U-109 Waste Received History. ${ }^{1,2}$

\begin{tabular}{|c|c|c|c|c|}
\hline & (3) & 箖 1110 & DEthming & Whster 6010 \\
\hline Thanderoginec & Whste Iypo Tecery & Petiod & The & Kg: \\
\hline 241-U-108 cascade & $\begin{array}{l}\text { Metal waste from } \\
\mathrm{BiPO}_{4} \text { process }\end{array}$ & 1949 & 2,006 & 530 \\
\hline 241-U-108 cascade & $\begin{array}{l}\text { Metal waste from } \\
\mathrm{BiPO}_{4} \text { process }\end{array}$ & $\overline{1954}$ & 1,688 & 446 \\
\hline $241-U-110$ & REDOX supernate & 1956 & 1,552 & 410 \\
\hline $241-U-107$ & Supernate & 1969 & 958 & 253 \\
\hline $241-\mathrm{U}-112$ & Supernate & $1974-1975$ & 106 & 28 \\
\hline $241-S-102$ & Evaporator bottoms & 1975 & 1,332 & 352 \\
\hline $241-S-102$ & Residual liquor & $19 \overline{77}$ & 466 & 123 \\
\hline
\end{tabular}

Notes:

${ }^{1}$ Waste volumes and types are best estimates based on historical data.

${ }^{2}$ Agnew et al. (Baldwin 1996b)

${ }^{3}$ See Figure 2-4 for complete transfer history.

Based on the TLM, tank 241-U-109 contains four layers of waste, not including the supernate. Listed from last deposit into the tank to the first deposit, these are $685 \mathrm{~kL}$ (181 $\mathrm{kgal})$ of SMMS2, $814 \mathrm{~kL}$ (215 kgal) of SSMS1, $91 \mathrm{~kL}(24 \mathrm{kgal})$ of REDOX cladding waste (CWRl), and $91 \mathrm{~kL}$ (24 kgal) of metal waste (MW). A graphical representation of the estimated waste types and volumes for these layers can be seen in Figure 2-3. The waste types in Figure 2-3 in parentheses "( )" are unknowns that are believed to be the indicated waste type.

The MW (bottom waste layer) should contain, from highest concentration above one weight percent, the following major constituents: uranium, hydroxide, sodium, carbonate, and phosphate. Constituents contained in this layer above a tenth of a weight percent are: sulfate, iron, nitrate, and calcium. The CRW1 layer should contain, from highest concentration above one weight percent, the following constituents: hydroxide, aluminum, sodium, nitrite, uranium, nitrate, and lead. Constituents contained in this layer above a tenth of a weight percent are: iron, carbonate, and calcium. The SMMS1 and SMMS2 layers may be difficult to distinguish and have similar inventories. Both SMMS1 and SMMS2 should contain, from highest concentration above one weight percent, the following major constituents: nitrate, sodium, hydroxide, nitrite, aluminum, carbonate, and sulfate. Constituents contained in these waste types above a tenth of a weight percent are: phosphate, chromium and calcium. Table 2-4 presents the historical tank content estimate for tank 241-U-109. 
Figure 2-3. Tank Layer Model for Tank 241-U-109.

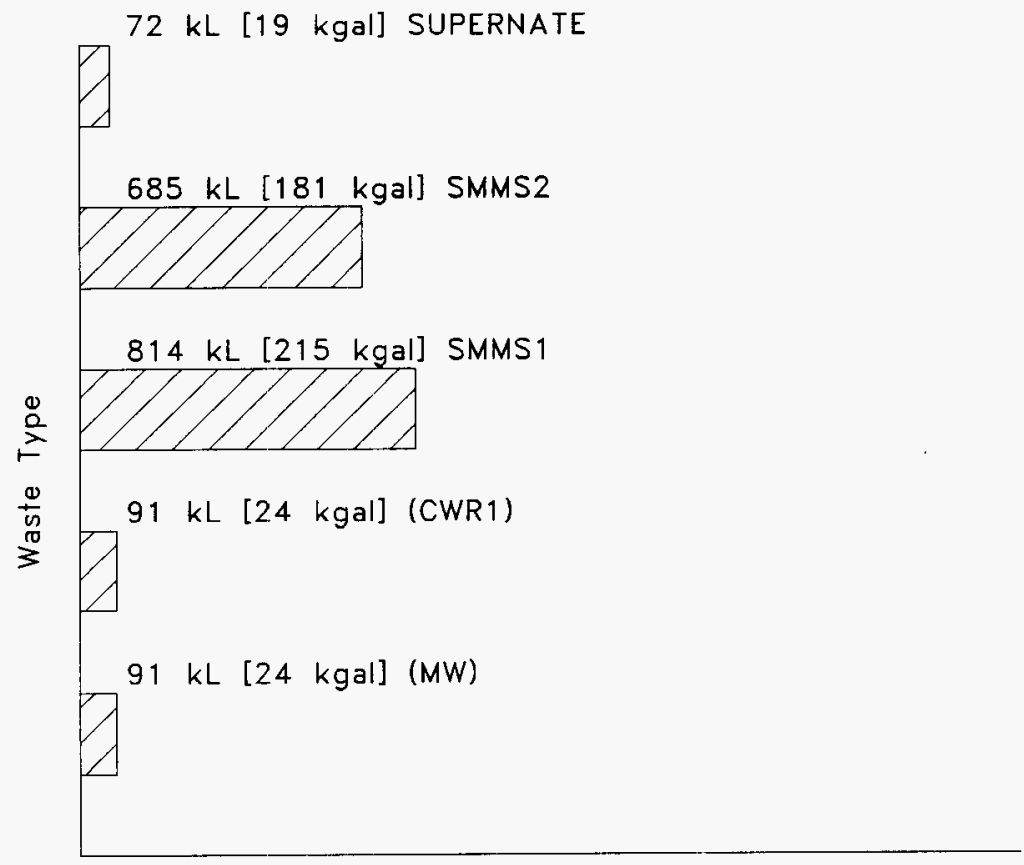

Waste Volume 
Table 2-4. Tank 241-U-109 Historical Tank Content Estimate. ${ }^{1,2}$ (2 sheets)

\begin{tabular}{|c|c|c|c|}
\hline \multirow{2}{*}{\multicolumn{4}{|c|}{ 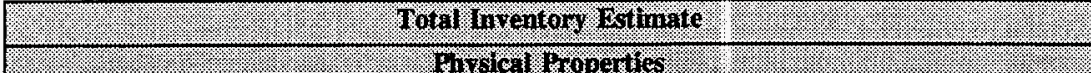 }} \\
\hline & & & \\
\hline Total solid waste & \multicolumn{3}{|c|}{$3.00 \mathrm{E}+06 \mathrm{~kg}(463 \mathrm{kgal})$} \\
\hline Heat load & \multicolumn{3}{|c|}{$4,120 \mathrm{~W}(14,100 \mathrm{Btu} / \mathrm{hr})$} \\
\hline Bulk density & \multicolumn{3}{|l|}{$1.71(\mathrm{~g} / \mathrm{mL})$} \\
\hline Water wt\% & \multicolumn{3}{|l|}{27.3} \\
\hline $\begin{array}{l}\text { TOC } \\
\text { wt\% Carbon (wet) }\end{array}$ & \multicolumn{3}{|l|}{1.02} \\
\hline Chemicri Gonstutients : & M. & 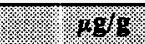 & 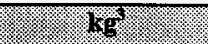 \\
\hline $\mathrm{Na}^{+}$ & 14.2 & $1.91 \mathrm{E}+05$ & $5.74 \mathrm{E}+05$ \\
\hline$\overline{\mathrm{Al}^{3+}}$ & 2.42 & 38,200 & $1.15 \mathrm{E}+05$ \\
\hline $\mathrm{Fe}^{3+}($ total Fe $)$ & 0.0234 & 764 & 2,290 \\
\hline $\mathrm{Cr}^{3+}$ & 0.0690 & 2,090 & 6,290 \\
\hline $\mathrm{Bi}^{3+}$ & 0.00128 & 156 & 468 \\
\hline $\mathrm{La}^{3+}$ & $3.77 \mathrm{E}-05$ & 3.05 & 9.17 \\
\hline $\mathrm{Hg}^{2+}$ & $2.21 \mathrm{E}-04$ & 25.9 & 77.7 \\
\hline $\mathrm{Zr}$ (as $\left.\mathrm{ZrO}(\mathrm{OH})_{2}\right)$ & $8.76 \mathrm{E}-04$ & 46.7 & 140 \\
\hline$\overline{\mathrm{Pb}^{2+}}$ & 0.00720 & 871 & 2,620 \\
\hline $\mathrm{Ni}^{2+}$ & 0.00754 & 258 & 776 \\
\hline $\mathrm{Sr}^{2+}$ & $1.26 \mathrm{E}-05$ & 0.642 & 1.93 \\
\hline $\mathrm{Mn}^{4+}$ & 0.00476 & 153 & 458 \\
\hline $\mathrm{Ca}^{2+}$ & 0.0503 & 1,180 & 3,530 \\
\hline $\mathrm{K}^{+}$ & 0.0641 & 1,460 & 4,390 \\
\hline$\overline{\mathrm{OH}^{-}}$ & 10.9 & $1.08 \mathrm{E}+05$ & $3.25 \mathrm{E}+05$ \\
\hline $\mathrm{NO}_{3}{ }^{-}$ & 5.87 & $2.13 \mathrm{E}+05$ & $6.38 \mathrm{E}+05$ \\
\hline $\mathrm{NO}_{2}^{-}$ & 2.81 & 75,400 & $2.26 \mathrm{E}+05$ \\
\hline $\mathrm{CO}_{3}{ }^{2-}$ & 0.640 & 22,400 & 67,300 \\
\hline $\mathrm{PO}_{4}{ }^{3-}$ & 0.122 & 6,770 & 20,300 \\
\hline $\mathrm{SO}_{4}^{2-}$ & 0.291 & 16,300 & 48,900 \\
\hline $\mathrm{Si}\left(\right.$ as $\left.\mathrm{SiO}_{3}{ }^{2}\right)$ & 0.0968 & 1,590 & 4,770 \\
\hline$\overline{F^{-}}$ & 0.0721 & 800 & 2,400 \\
\hline$\overline{\mathrm{Cl}^{-}}$ & 0.239 & 4,940 & 14,800 \\
\hline
\end{tabular}


WHC-SD-WM-ER-609 Rev. 0

Table 2-4. Tank 241-U-109 Historical Tank Content Estimate. ${ }^{1,2}$ (2 sheets)

\begin{tabular}{|c|c|c|c|}
\hline Gherical Constituent & (2) & (2) & 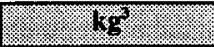 \\
\hline Citrate $^{3-}$ & 0.0382 & 4,213 & 12,600 \\
\hline EDTA $^{4}$ & 0.0226 & 3,800 & 11,400 \\
\hline HEDTA $^{3-}$ & 0.0421 & 6,730 & 20,200 \\
\hline glycolate & 0.131 & 5,740 & 17,200 \\
\hline acetate $^{-}$ & 0.0101 & 347 & 1,040 \\
\hline oxalate ${ }^{2-}$ & $3.22 \mathrm{E}-05$ & 1.66 & 4.97 \\
\hline$\overline{\mathrm{DBP}}$ & 0.0239 & 3,720 & 11,200 \\
\hline Butanol & 0.0239 & 1,040 & 3,110 \\
\hline $\mathrm{NH}_{3}$ & 0.0652 & 647 & 1,940 \\
\hline $\mathrm{Fe}(\mathrm{CN})_{6}{ }^{4}$ & 0 & 0 & 0 \\
\hline Radiological Constituents & CWL & (4018: & (1) \\
\hline $\mathrm{Pu}$ & -- & 0.134 & $6.78(\mathrm{~kg})$ \\
\hline $\mathrm{U}$ & $0.127(\underline{M})$ & $17,700(\mu \mathrm{g} / \mathrm{g})$ & $53,000(\mathrm{~kg})$ \\
\hline Cs & 0.286 & 167 & $5.01 \mathrm{E}+05$ \\
\hline Sr & 0.15 & 87.7 & $2.63 \mathrm{E}+05$ \\
\hline
\end{tabular}

Notes:

'Agnew et al. (Baldwin 1996a)

2The HTCE predictions have not been validated and should be used with caution.

${ }^{3}$ Small differences appear to exist among the inventories in this column and the inventories calculated from the two sets of concentrations. These differences are being evaluated.

\subsection{SURVEILLANCE DATA}

Tank 241-U-109 surveillance includes surface level measurements (liquid and solid) and temperature monitoring inside the tank (waste and vapor space). The data provide the basis for determining tank integrity.

Liquid level measurements may indicate if there is a major leak from a tank. Solid surface level measurements provide an indication of physical changes and consistency of the solid layers. Tank 241-U-109 has one liquid observation well, in riser 9, used to measure interstitial liquid levels. Four drywells located around the perimeter of the tank monitor 
change in radiation due to possible waste leakage. None of the drywells show increased radiation levels above background.

\subsubsection{Surface Level}

The surface level of the waste is monitored with an ENRAF ${ }^{\circ}$ surface level measurement system through riser 8 . The allowable deviations from the tank $241-\mathrm{U}-109$ baseline of $4.18 \mathrm{~m}(164.6 \mathrm{in}$.) are a $7.5 \mathrm{~cm}$ (3 in.) increase and a $2.5 \mathrm{~cm}(1 \mathrm{in}$.) decrease in two weeks. On June 23, 1996, the surface level from the automatic ENRAF ${ }^{\circledR}$ system was $4.49 \mathrm{~m}$ (176.7 in.). On February 6, 1996, the surface level reading from the automatic ENRAF system increased from $4.17 \mathrm{~m}$ (164.3 in.) to $4.48 \mathrm{~m}$ (176.4 in.). This exceeded the increase criterion. There was no logical explanation for the increase, and the surface level has remained steady since that time. A graph of the tank volume history is presented in Figure 2-4.

\subsubsection{Internal Tank Temperatures}

Tank 241-U-109 has a thermocouple (TC) tree located in riser 1, with 11 TCs to monitor the waste temperature. Elevations are available for all TCs. Tank 241-U-109 is on the Flammable Gas Watch List and has a weekly temperature reading requirement. Plots of the individual TC readings can be found in the U Tank Farm supporting document for the HTCE (Brevick et al. 1994).

Temperature data, obtained from the Surveillance Analysis Computer System (SACS) (WHC 1996), were recorded from July 1987 through June 1996. Data were available for all $11 \mathrm{TCs}$. The mean temperature of the SACS data is $26.8^{\circ} \mathrm{C}\left(80.3^{\circ} \mathrm{F}\right)$, with a minimum of $15.8^{\circ} \mathrm{C}\left(60.5^{\circ} \mathrm{F}\right)$ and a maximum of $36^{\circ} \mathrm{C}\left(96^{\circ} \mathrm{F}\right)$. The mean temperature of the SACS data over the last year (June 1995 through June 1996) is $27.3^{\circ} \mathrm{C}\left(81.2^{\circ} \mathrm{F}\right.$ ), with a minimum of $19^{\circ} \mathrm{C}\left(66.2^{\circ} \mathrm{F}\right)$ and a maximum of $31.3^{\circ} \mathrm{C}\left(88.3^{\circ} \mathrm{F}\right)$. On June 23,1996 , the low temperature recorded was $22.1^{\circ} \mathrm{C}\left(71.78^{\circ} \mathrm{F}\right)$ on $\mathrm{TC} 10$ (located in the vapor space). The high temperature recorded was $29^{\circ} \mathrm{C}\left(84.2^{\circ} \mathrm{F}\right)$ on TC 2 (located in the waste). The graph of the weekly high temperatures is provided in Figure 2-5. 
Figure 2-4. Tank 241-U-109 Level History.

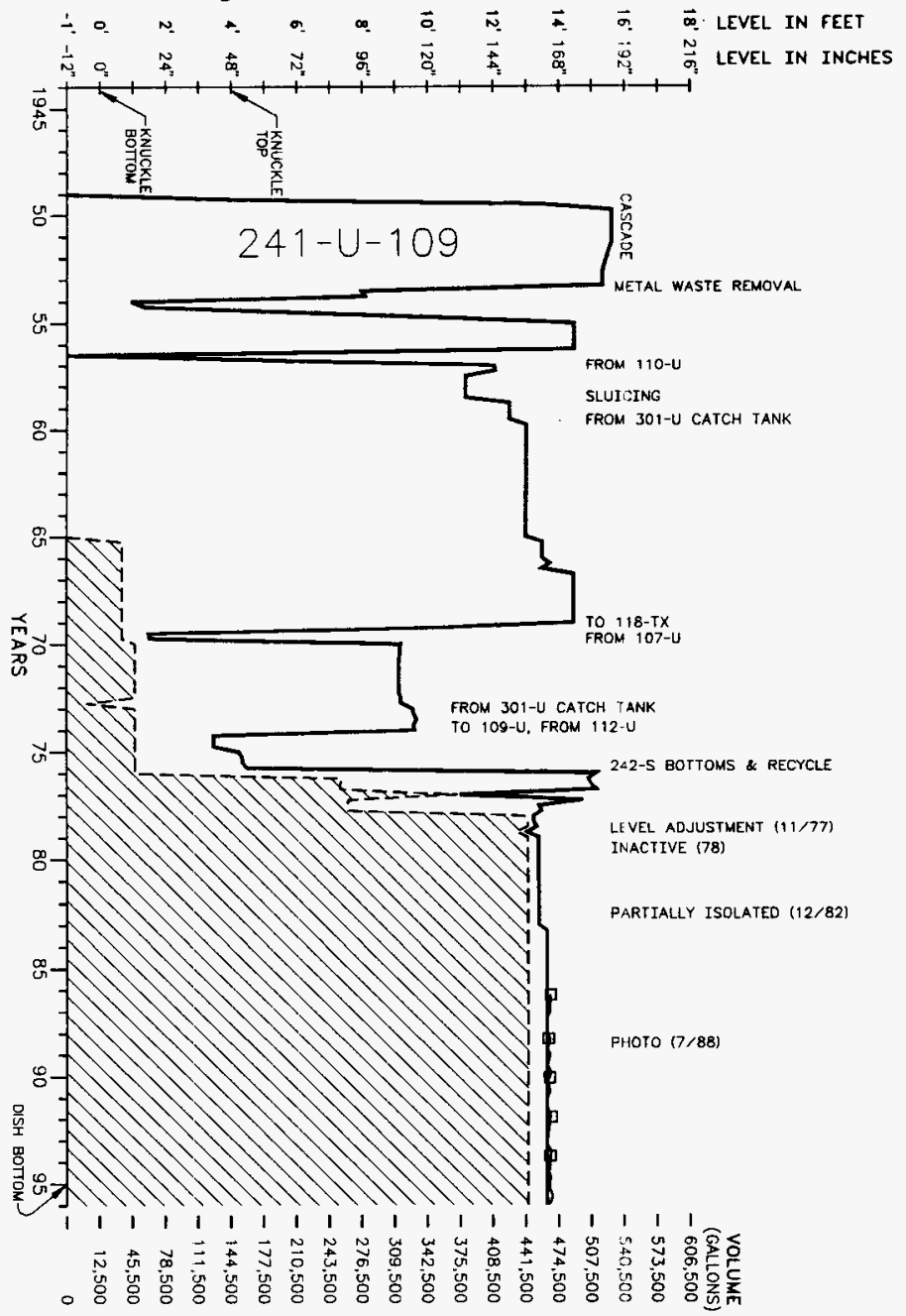


Figure 2-5. Tank 241-U-109 Weekly High Temperature Plot.

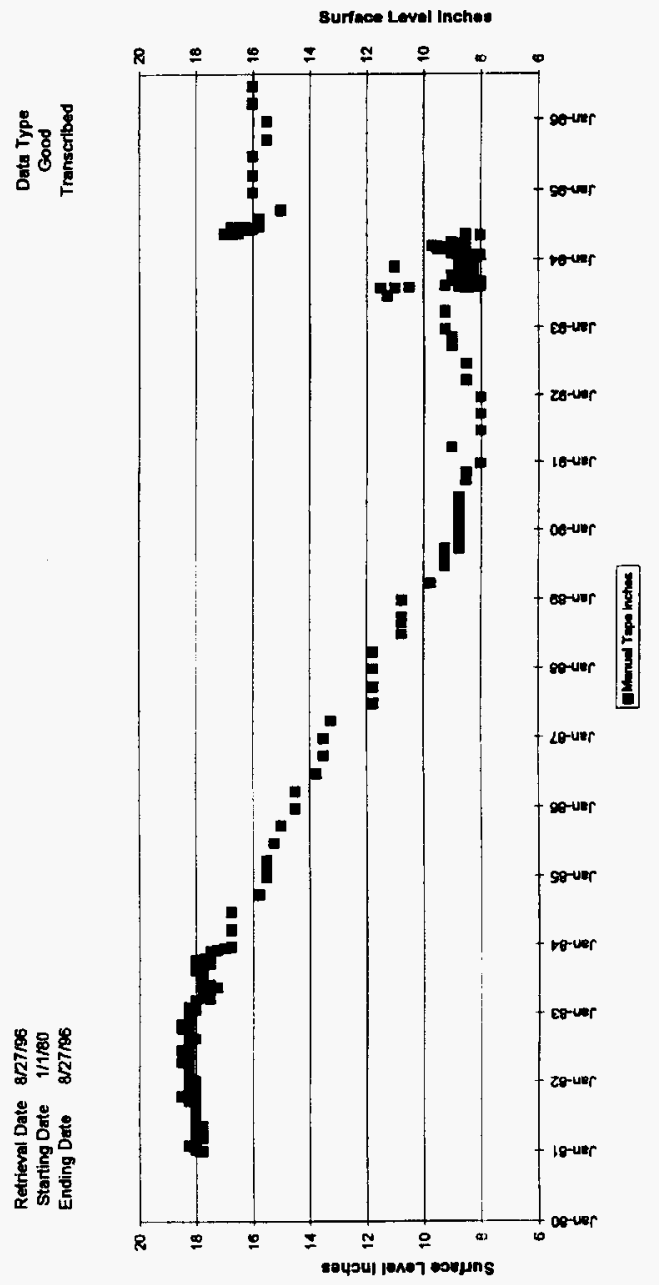




\subsubsection{Tank 241-U-109 Photographs}

The 1988 photographic montage of the tank 241-U-109 interior shows the waste surface to be a mixture of solids and liquids, with what appears to be an orange-colored saltcake floating on top of the liquid. The volume of waste in the tank, 1,753 kL (463 kgal), has not changed since the photographs were taken; therefore, the photographic montage (Figure 2-6) could still represent the current appearance of the tank waste.

\subsection{HYDROGEN GAS MONITORING}

Tank 241-U-109 is equipped with standard hydrogen monitoring system (SHMS) cabinets. The SHMS data, vapor grab sample analysis data, and sniff data collected for tank 241-U-109 between July 1995 and February 1996 are reported in Brown (1996). 


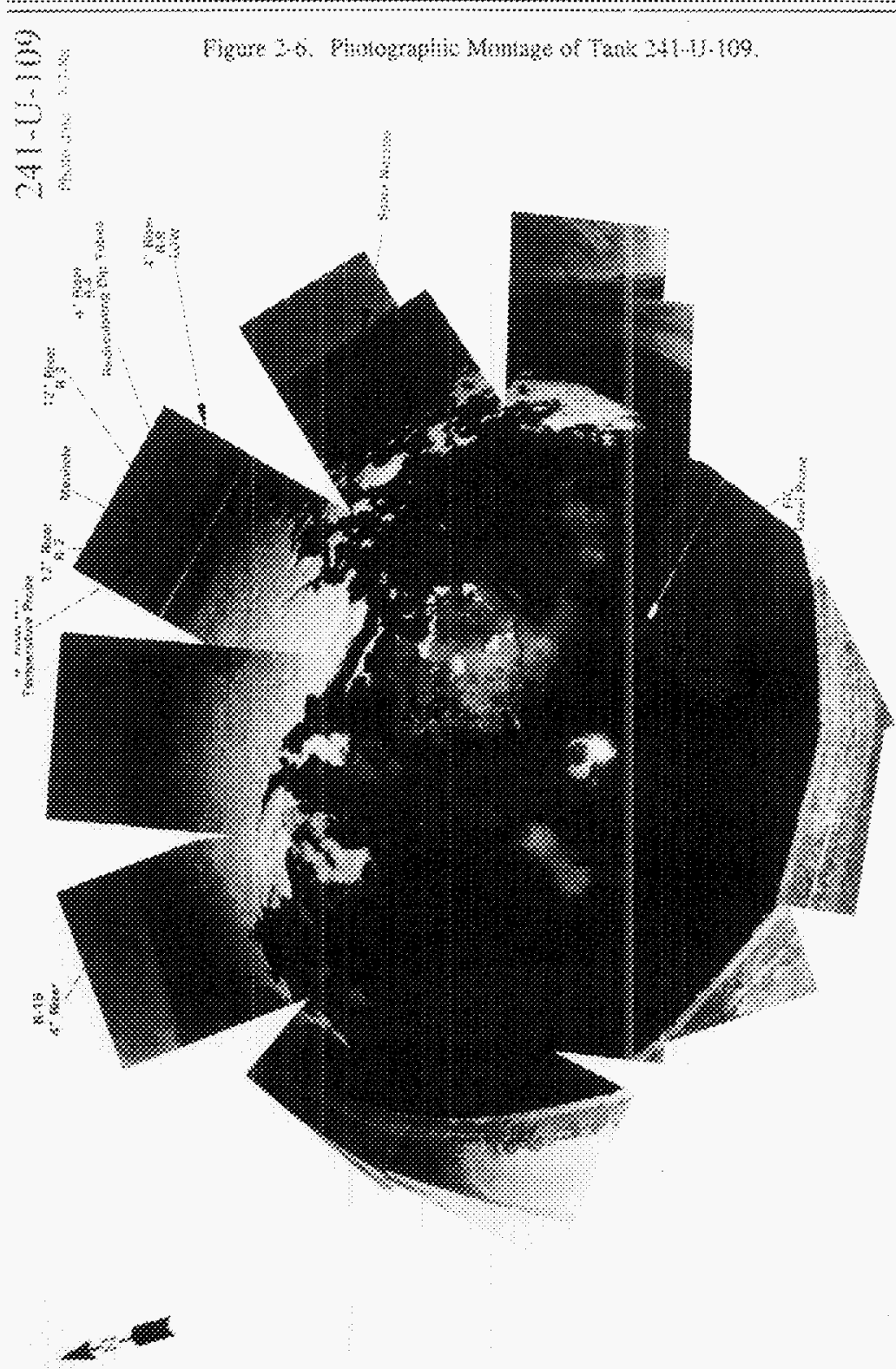




\subsection{TANK SAMPLING OVERVIEW}

This section describes the December 1995 and January 1996 sampling and analysis events for tank 241-U-109. Three push-mode core samples using a rotary core truck were taken to satisfy the requirements of the safety screening DQO (Dukelow et al. 1995), the organic complexant safety DQO (Turner et al. 1995), the organic safety test plan (Meacham 1995), and the historical model evaluation DQO (Simpson and McCain 1995). The sampling and analysis were performed in accordance with the sampling and analysis plan (SAP) (Baldwin 1996b). Further discussions of the sampling and analysis procedures can be found in the Tank Characterization Reference Guide (DeLorenzo et al. 1994).

Table 3-1 summarizes the sampling mode, applicable DQOs, and sampling and analysis requirements for the 1995/1996 sampling event.

\subsection{DESCRIPTION OF SAMPLING EVENT}

Three push-mode core samples (using a rotary core truck) were collected from tank 241-U-109 between December 20, 1995 and January 19, 1996 . Cores 123, 124, and 128 were obtained from risers 2,19 , and 7 , respectively. Water was used to wash the drill string during sampling operations. A tracer (lithium bromide) was added to the wash water to gauge contamination of the segments by the wash water. A field blank and a wash-water HHF blank were also obtained. All samples were received and extruded at the Westinghouse Hanford Company 222-S Laboratory in accordance with the SAP (Baldwin 1996b).

In addition, the tank headspace vapors were measured for flammable gas concentration as required by the safety screening $D Q O$.

\subsection{SAMPLE HANDLING}

Cores 123,124 , and 128 were received by the Westinghouse Hanford Company 222-S Laboratory between December 21, 1995 and January 22, 1996. These cores were extruded between January 2 and January 26, 1996.

Only segment 3 of core 124 contained drainable liquid (DL). The remaining segments of the three cores were full of saltcake-like solids with slightly different textures. Sample recovery was variable, depending on the particular segment. No separable organic layer was observed in any of the segments. One field blank and one wash-water HHF blank were delivered to the 222-S Laboratory with core 124. All three cores were subsampled at the whole-segment, half-segment, or third-segment level for analysis, depending on the amount of material recovered and the appearance of the extruded segments. Core composites were formed in accordance with the historical model evaluation DQO. 
Table 3-1. Integrated Data Quality Objective Requirements for Tank 241-U-109. ${ }^{1}$

\begin{tabular}{|c|c|c|c|}
\hline Manping & 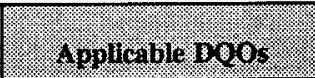 & pequinguris & 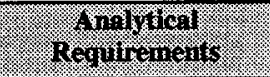 \\
\hline \multirow[t]{3}{*}{$\begin{array}{l}\text { Push-mode } \\
\text { core sampling } \\
\text { (December } \\
\text { 1995/January } \\
\text { 1996) }\end{array}$} & $\begin{array}{l}\text { Safety screening } \\
\text { (Dukelow et al. 1995) }\end{array}$ & \multirow[t]{3}{*}{$\begin{array}{l}\text { Core samples from a } \\
\text { minimum of two risers } \\
\text { separated radially to } \\
\text { the maximum extent } \\
\text { possible. } \\
\text { Flammability taken in } \\
\text { tank headspace. }\end{array}$} & $\begin{array}{l}\text { - Energetics } \\
\text { - Moisture content } \\
\text { - Total alpha activity } \\
\text { - Bulk density } \\
\text { - Headspace gas } \\
\text { flammability }\end{array}$ \\
\hline & $\begin{array}{l}\text { Organic complexant safety } \\
\text { (Turner et al. 1995) }\end{array}$ & & $\begin{array}{l}\text { - Energetics } \\
\text { - Moisture content } \\
\text { - TOC }\end{array}$ \\
\hline & $\begin{array}{l}\text { Historical model } \\
\text { evaluation } \\
\text { (Simpson and McCain } \\
1995 \text { ) }\end{array}$ & & $\begin{array}{l}\text { - Energetics } \\
\text { - Moisture content } \\
\text { - }{ }^{137} \mathrm{Cs} \\
\text { - TIC } \\
\text { - Metais } \\
\text { - Anions } \\
\text { - Total alpha activity } \\
\text { - Bulk density } \\
\text { - TOC } \\
\text { - Uranium } \\
\text { - Total beta } \\
\text { - }{ }^{29 / 90} \mathrm{Sr}^{2}\end{array}$ \\
\hline & $\begin{array}{l}\text { Organic safety test plan } \\
\text { (Meacham 1995) }\end{array}$ & & $\begin{array}{l}\text { - Energetics } \\
\text { - Moisture content } \\
\text { - TOC }\end{array}$ \\
\hline
\end{tabular}

Notes:

${ }^{1}$ (Baldwin 1996b)

${ }^{2}$ Secondary requirements.

Table 3-2 presents the subsampling scheme, the amount of sample recovered, the dose rates, and a description of the sample visual characteristics. 
Table 3-2. Subsampling Scheme and Sample Description ${ }^{1}$. (4 sheets)

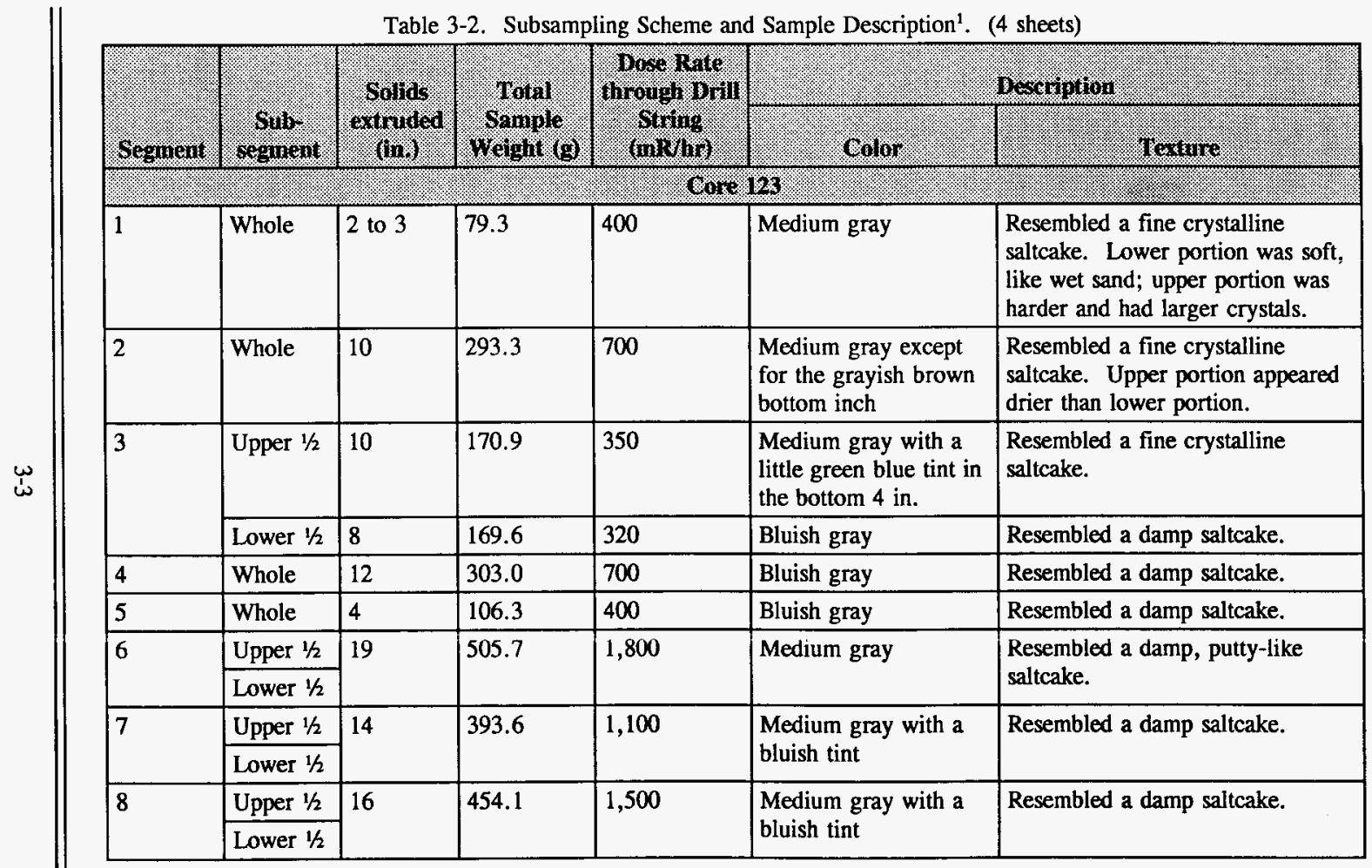


Table 3-2. Subsampling Scheme and Sample Description' ${ }^{1}$ (4 sheets)

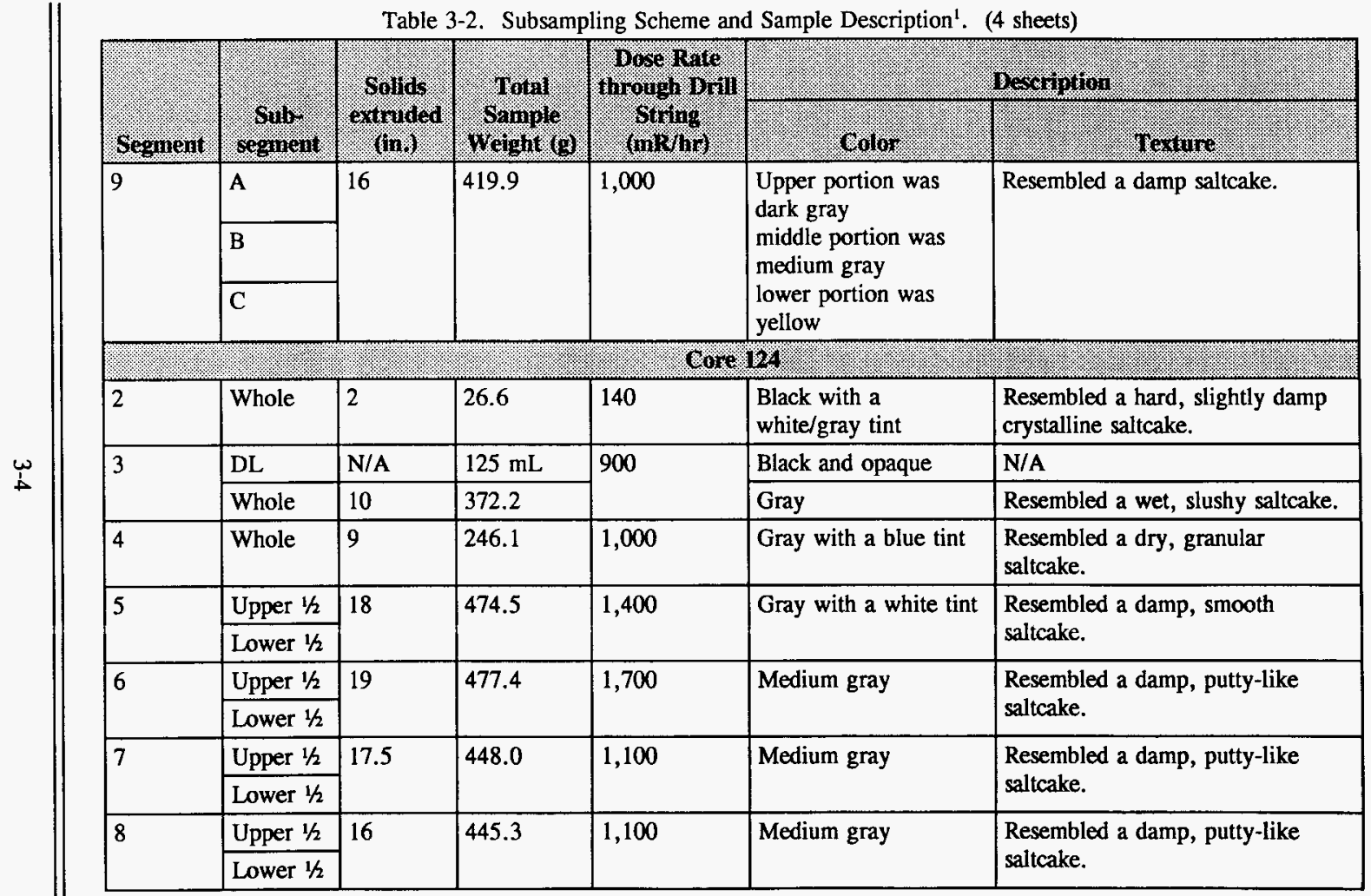


Table 3-2. Subsampling Scheme and Sample Description ${ }^{1}$. (4 sheets)

\begin{tabular}{|c|c|c|c|c|c|c|}
\hline (8) & 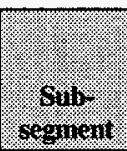 & $\begin{array}{l}\text { Sollds } \\
\text { erimiad } \\
\text { (in) }\end{array}$ & 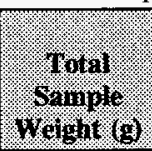 & $\begin{array}{l}\text { Dose Rato } \\
\text { through bril } \\
\text { siring } \\
(\mathrm{muhh})\end{array}$ & $8010 \%$ & 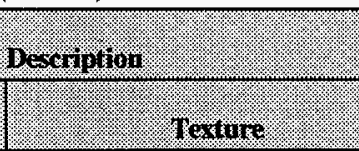 \\
\hline \multirow[t]{2}{*}{9} & Upper $1 / 2$ & \multirow[t]{2}{*}{12} & \multirow[t]{2}{*}{249.5} & \multirow[t]{2}{*}{700} & Black & Resembled a smooth saltcake. \\
\hline & Lower $1 / 2$ & & & & Gray & $\begin{array}{l}\text { Resembled a slightly pitted } \\
\text { saltcake. }\end{array}$ \\
\hline $\begin{array}{l}\text { Field } \\
\text { blank }\end{array}$ & $n / a$ & $n / a$ & $\overline{---}$ & $<0.5$ & \multicolumn{2}{|c|}{ Clear liquid. No solids. No liner liquid. } \\
\hline HHF & $n / a$ & $n / a$ & -- & $<0.5$ & \multicolumn{2}{|l|}{ N/A } \\
\hline \multicolumn{7}{|c|}{ ( } \\
\hline 1 & Whole & 3 & 70.4 & 250 & Medium gray & Wet, crumbly saltcake \\
\hline 2 & Whole & 6 & 143.9 & 300 & $\begin{array}{l}\text { Medium gray with a } \\
\text { bluish tint }\end{array}$ & Resembled a saltcake. \\
\hline 3 & Whole & 10 & 216.1 & 800 & $\begin{array}{l}\text { Medium gray with a } \\
\text { bluish tint }\end{array}$ & Resembled a damp saltcake. \\
\hline \multirow[t]{2}{*}{4} & Upper $1 / 2$ & \multirow[t]{2}{*}{14} & \multirow[t]{2}{*}{314.4} & \multirow[t]{2}{*}{1,500} & \multirow[t]{2}{*}{ Dark gray } & \multirow[t]{2}{*}{ Resembled a wet saltcake. } \\
\hline & Lower $1 / 2$ & & & & & \\
\hline 5 & Whole & 7 & 175.0 & 1,000 & Dark gray & Resembled a saltcake. \\
\hline \multirow[t]{2}{*}{6} & Upper $1 / 2$ & \multirow[t]{2}{*}{16} & \multirow[t]{2}{*}{381.4} & \multirow[t]{2}{*}{1,000} & \multirow[t]{2}{*}{ Dark gray } & \multirow[t]{2}{*}{ Resembled a wet saltcake. } \\
\hline & Lower $1 / 2$ & & & & & \\
\hline \multirow[t]{2}{*}{7} & Upper $1 / 2$ & \multirow[t]{2}{*}{18} & \multirow[t]{2}{*}{403.2} & \multirow[t]{2}{*}{1,000} & \multirow[t]{2}{*}{ Dark gray } & \multirow[t]{2}{*}{ Resembled a damp saltcake. } \\
\hline & Lower $1 / 2$ & & & & & \\
\hline
\end{tabular}




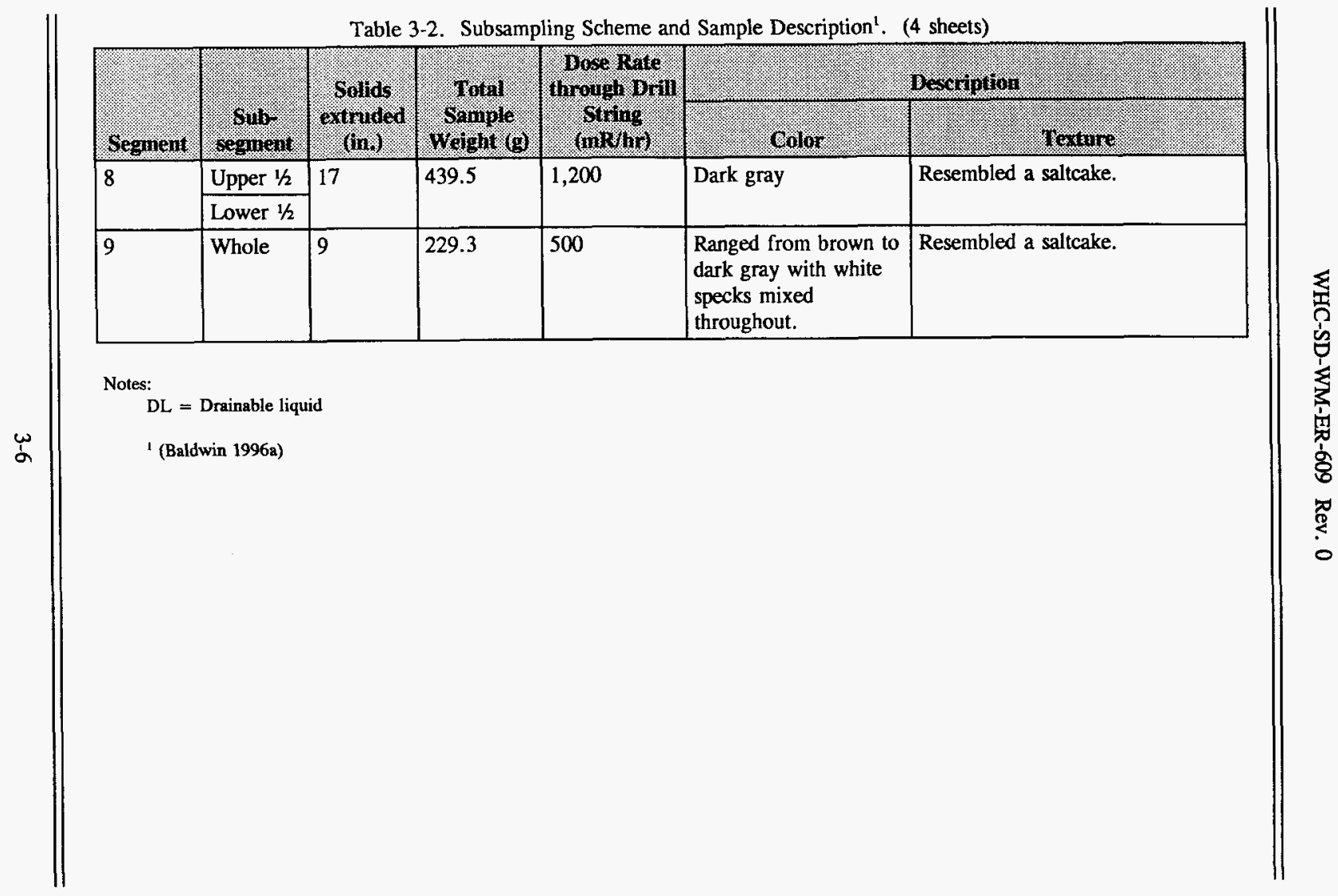




\subsection{SAMPLE ANALYSIS}

As noted in Table 3-1, the safety screening DQO required analyses for thermal properties by DSC, moisture by TGA, fissile content by total alpha analysis, and bulk density (specific gravity for the drainable liquid sample). In addition to the core samples, the flammability of the tank headspace was measured before core sampling.

Bromide analysis by IC and lithium analysis by ICP were required by the SAP to determine the amount of HHF contamination in the samples. Nitrate and several metals were also reported as a result of the IC and ICP analyses, in order to satisfy the requirements of the historical model evaluation DQO.

The historical model key analytes were confirmed to be present, and therefore the DQO required secondary analyses on selected subsegments and core composites. These were in addition to the key analytes aluminum, chromium, sodium, nitrate, TIC, and weight percent water, and the other primary analytes DSC and ${ }^{137} \mathrm{Cs}$. The IC analyses for nitrate were performed on each selected solid subsegment and core composite after preparation by a water leach, as required by the historical model evaluation DQO. For all ICP analyses, the solid subsegments and core composites were prepared using a potassium hydroxide fusion digestion in a zirconium crucible. The drainable liquid sample from segment 3 of core 124 was diluted with acid before ICP analysis. An ICP analysis for aluminum, chromium, and sodium was also performed on a water-leached aliquot from each of the core composite samples, and on the segments that were selected for the secondary historical analyses as most representative of their waste type based on the key analyte analysis (Baldwin 1996a). Additional analytes required by the historical model evaluation DQO included bismuth, calcium, iron, manganese, nickel, phosphorus, silicon, and uranium. Secondary analytes included TOC, total alpha activity, bulk density, total beta, ${ }^{89 / 90} \mathrm{Sr}$, as well as uranium analyzed by laser fluorimetry.

The organic complexant safety DQO and the organic safety test plan also required DSC, TOC, and weight percent water as primary analyses.

Laboratory control checks included, where appropriate, laboratory control standards, matrix spikes, duplicate analyses, and blanks. An assessment of the quality control (QC) procedures and data is presented in Section 5.1.2 of this report.

All reported analyses were performed in accordance with approved laboratory procedures. A list of the sample numbers and applicable analyses is presented in Table 3-3. Table 3-4 displays the analytical procedures by title and number. No deviations or modifications were noted by the laboratory. 
Table 3-3. Summary of Samples and Analyses.. ${ }^{1}$ (6 sheets)

\begin{tabular}{|c|c|c|c|}
\hline Core & Siqunent & $\begin{array}{l}\text { Segrnein } \\
\text { portion: }\end{array}$ & Analyses. \\
\hline \multirow[t]{8}{*}{123} & 1 & Whole & $\begin{array}{l}\text { DSC, TGA, TIC, TOC } \\
\text { Bulk Density } \\
\text { IC } \\
\text { ICP (Fusion), Alpha, GEA }\end{array}$ \\
\hline & 2 & Whole & $\begin{array}{l}\text { DSC, TGA, TIC, TOC } \\
\text { Bulk Density } \\
\text { IC } \\
\text { ICP (Fusion), Alpha, GEA }\end{array}$ \\
\hline & \multirow[t]{2}{*}{3} & Upper $1 / 2$ & $\begin{array}{l}\text { DSC, TGA, TIC, TOC } \\
\text { Bulk Density } \\
\text { IC } \\
\text { ICP (Fusion), Alpha, GEA }\end{array}$ \\
\hline & & Lower $1 / 2$ & $\begin{array}{l}\text { DSC, TGA, TIC, TOC } \\
\text { Bulk Density } \\
\text { IC } \\
\text { ICP (Fusion), Alpha, GEA }\end{array}$ \\
\hline & 4 & Whole & $\begin{array}{l}\text { DSC, TGA, TIC, TOC } \\
\text { Bulk Density } \\
\text { IC } \\
\text { ICP (Fusion), Alpha, GEA, U, }{ }^{89 / 90} \mathrm{Sr} \text {, Beta } \\
\text { ICP (Acid Digest) }\end{array}$ \\
\hline & 5 & Whole & $\begin{array}{l}\text { DSC, TGA, TIC, TOC } \\
\text { Bulk Density } \\
\text { IC } \\
\text { ICP (Fusion), Alpha, GEA }\end{array}$ \\
\hline & \multirow[t]{2}{*}{6} & Upper $1 / 2$ & $\begin{array}{l}\text { TGA, TIC, TOC } \\
\text { Bulk Density } \\
\text { IC } \\
\text { ICP (Fusion), GEA }\end{array}$ \\
\hline & & Lower $1 / 2$ & $\begin{array}{l}\text { Bulk Density } \\
\text { DSC, TGA, TIC, TOC } \\
\text { IC } \\
\text { ICP (Fusion), Alpha, GEA, Beta, U, }{ }^{89 / 90} \mathrm{Sr} \\
\text { ICP (Acid Digest) }\end{array}$ \\
\hline
\end{tabular}


Table 3-3. Summary of Samples and Analyses. ${ }^{1}$ (6 sheets)

\begin{tabular}{|c|c|c|c|}
\hline Core & Segriera & $\begin{array}{l}\text { Segment } \\
\text { Toution }\end{array}$ & Arralyses \\
\hline \multirow[t]{8}{*}{123} & \multirow[t]{2}{*}{7} & Upper $1 / 2$ & $\begin{array}{l}\text { TGA, TIC, TOC } \\
\text { Bulk Density } \\
\text { IC } \\
\text { ICP (Fusion), GEA }\end{array}$ \\
\hline & & Lower $1 / 2$ & $\begin{array}{l}\text { Bulk Density } \\
\text { TGA, DSC, TIC, TOC } \\
\text { IC } \\
\text { ICP (Fusion), Alpha, GEA }\end{array}$ \\
\hline & \multirow[t]{2}{*}{8} & Upper $1 / 2$ & $\begin{array}{l}\text { DSC, TGA, TIC, TOC } \\
\text { Bulk Density } \\
\text { IC } \\
\text { ICP (Fusion), GEA }\end{array}$ \\
\hline & & Lower $1 / 2$ & $\begin{array}{l}\text { Bulk Density } \\
\text { TGA, DSC, TIC, TOC } \\
\text { IC } \\
\text { ICP (Fusion), Alpha, GEA }\end{array}$ \\
\hline & \multirow[t]{3}{*}{9} & A & $\begin{array}{l}\text { DSC, TGA, TIC, TOC } \\
\text { Bulk Density } \\
\text { IC } \\
\text { ICP (Fusion), GEA }\end{array}$ \\
\hline & & $\bar{B}$ & $\begin{array}{l}\text { Bulk Density } \\
\text { TGA, DSC, TIC, TOC } \\
\text { IC } \\
\text { ICP (Fusion), GEA }\end{array}$ \\
\hline & & $\bar{C}$ & $\begin{array}{l}\text { Bulk Density } \\
\text { TGA, DSC, TIC, TOC } \\
\text { IC } \\
\text { ICP (Fusion), GEA, Alpha }\end{array}$ \\
\hline & \multicolumn{2}{|c|}{ Composite } & $\begin{array}{l}\text { Bulk Density } \\
\text { DSC, TGA, TIC, TOC } \\
\text { ICP (Fusion), GEA, Alpha, Beta, U, }{ }^{89 / 90} \mathrm{Sr} \\
\text { IC } \\
\text { ICP (Acid Digest) }\end{array}$ \\
\hline
\end{tabular}


Table 3-3. Summary of Samples and Analyses. ${ }^{1}$ (6 sheets)

\begin{tabular}{|c|c|c|c|}
\hline (cone & segmint & 601010 & Hnalyos \\
\hline \multirow[t]{10}{*}{124} & 2 & Whole & $\begin{array}{l}\text { DSC, TGA, TIC, TOC } \\
\text { ICP (Fusion), GEA, Alpha } \\
\text { IC }\end{array}$ \\
\hline & \multirow[t]{2}{*}{3} & $\overline{D L}$ & $\begin{array}{l}\text { DSC, SpG, TGA, TOC, ICP (Acid Dilution), } \\
\text { IC, Alpha }\end{array}$ \\
\hline & & Whole & $\begin{array}{l}\text { Bulk Density } \\
\text { TGA, DSC, TIC, TOC } \\
\text { ICP (Fusion), GEA, Alpha, Beta, U, }{ }^{89 / 90} \mathrm{Sr} \\
\text { ICP (Acid Digest) }\end{array}$ \\
\hline & 4 & Whole & $\begin{array}{l}\text { Bulk Density } \\
\text { DSC, TGA, TIC, TOC } \\
\text { ICP (Fusion), GEA, Alpha } \\
\text { IC }\end{array}$ \\
\hline & \multirow[t]{2}{*}{5} & Upper $1 / 2$ & $\begin{array}{l}\text { Bulk Density } \\
\text { TGA, DSC, TIC, TOC } \\
\text { ICP (Fusion), GEA, Alpha } \\
\text { IC }\end{array}$ \\
\hline & & Lower $1 / 2$ & $\begin{array}{l}\text { Bulk Density } \\
\text { TGA, DSC, TIC, TOC } \\
\text { ICP (Fusion), GEA, Alpha } \\
\text { IC }\end{array}$ \\
\hline & \multirow[t]{2}{*}{6} & Upper $1 / 2$ & $\begin{array}{l}\text { Bulk Density } \\
\text { TGA, DSC, TIC, TOC } \\
\text { ICP (Fusion), GEA, Alpha } \\
\text { IC }\end{array}$ \\
\hline & & Lower $1 / 2$ & $\begin{array}{l}\text { Bulk Density } \\
\text { TGA, DSC, TIC, TOC } \\
\text { ICP (Fusion), GEA, Alpha } \\
\text { IC }\end{array}$ \\
\hline & \multirow[t]{2}{*}{7} & Upper $1 / 2$ & $\begin{array}{l}\text { Bulk Density } \\
\text { TGA, TIC, TOC } \\
\text { ICP (Fusion), GEA, Alpha } \\
\text { IC }\end{array}$ \\
\hline & & Lower $1 / 2$ & $\begin{array}{l}\text { Bulk Density } \\
\text { TGA, DSC, TIC, TOC } \\
\text { ICP (Fusion), GEA, Alpha } \\
\text { IC }\end{array}$ \\
\hline
\end{tabular}


Table 3-3. Summary of Samples and Analyses. ${ }^{1}$ ( 6 sheets)

\begin{tabular}{|c|c|c|c|}
\hline Orre & Germingt & 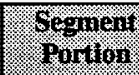 & 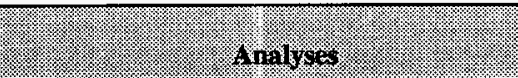 \\
\hline \multirow[t]{9}{*}{124} & \multirow[t]{2}{*}{8} & Upper $1 / 2$ & $\begin{array}{l}\text { Bulk Density } \\
\text { TGA, TIC, TOC } \\
\text { ICP (Fusion), GEA, Alpha, Beta, U, }{ }^{89 / 90} \mathrm{Sr} \\
\text { IC } \\
\text { ICP (Acid Digest) }\end{array}$ \\
\hline & & Lower $1 / 2$ & $\begin{array}{l}\text { Bulk Density } \\
\text { TGA, DSC, TIC, TOC } \\
\text { ICP (Fusion), GEA, Alpha } \\
\text { IC }\end{array}$ \\
\hline & \multirow[t]{2}{*}{9} & Upper $1 / 2$ & $\begin{array}{l}\text { Bulk Density } \\
\text { TGA, DSC, TIC, TOC } \\
\text { ICP (Fusion), GEA, Alpha } \\
\text { IC }\end{array}$ \\
\hline & & Lower $1 / 2$ & $\begin{array}{l}\text { Bulk Density } \\
\text { TGA, DSC, TIC, TOC } \\
\text { ICP (Fusion), GEA, Alpha } \\
\text { IC }\end{array}$ \\
\hline & \multicolumn{2}{|c|}{ Field Blank } & $\begin{array}{l}\text { DSC, SpG, TGA, TOC, ICP } \\
\text { (Acid Dilution), IC, Alpha }\end{array}$ \\
\hline & \multicolumn{2}{|l|}{ HHF } & Lithium, IC \\
\hline & \multicolumn{2}{|l|}{ Composite } & $\begin{array}{l}\text { Bulk Density } \\
\text { DSC, TGA, TIC, TOC } \\
\text { ICP (Fusion), GEA, Alpha, Beta, U, }{ }^{8990} \mathrm{Sr} \\
\text { IC } \\
\text { ICP (Acid Digest) }\end{array}$ \\
\hline & 1 & Whole & $\begin{array}{l}\text { Bulk Density } \\
\text { TGA, DSC, TIC, TOC } \\
\text { ICP (Fusion), GEA, Alpha } \\
\text { IC }\end{array}$ \\
\hline & 2 & Whole & $\begin{array}{l}\text { Bulk Density } \\
\text { TGA, DSC TIC, TOC } \\
\text { ICP (Fusion), GEA, Alpha, Beta, U, }{ }^{89 / 90} \mathrm{Sr} \\
\text { IC } \\
\text { ICP (Acid Digest) }\end{array}$ \\
\hline
\end{tabular}


WHC-SD-WM-ER-609 Rev. 0

Table 3-3. Summary of Samples and Analyses. ${ }^{1}$ (6 sheets)

\begin{tabular}{|c|c|c|c|}
\hline Core & Scomenin & $\begin{array}{l}\text { Segrinent } \\
\text { gontion }\end{array}$ & (1) \\
\hline \multirow[t]{8}{*}{128} & 3 & Whole & $\begin{array}{l}\text { Bulk Density } \\
\text { TGA, DSC, TIC, TOC } \\
\text { ICP (Fusion), GEA, Alpha } \\
\text { IC }\end{array}$ \\
\hline & \multirow[t]{2}{*}{$\overline{4}$} & Upper $1 / 2$ & $\begin{array}{l}\text { Bulk Density } \\
\text { TGA, DSC, TIC, TOC } \\
\text { ICP (Fusion), GEA, Alpha } \\
\text { IC }\end{array}$ \\
\hline & & Lower $1 / 2$ & $\begin{array}{l}\text { Bulk Density } \\
\text { TGA, DSC, TIC, TOC } \\
\text { ICP (Fusion), GEA, Alpha } \\
\text { IC }\end{array}$ \\
\hline & 5 & Whole & $\begin{array}{l}\text { Bulk Density } \\
\text { TGA, DSC, TIC, TOC } \\
\text { ICP (Fusion), GEA, Alpha } \\
\text { IC }\end{array}$ \\
\hline & \multirow[t]{2}{*}{6} & Upper $1 / 2$ & $\begin{array}{l}\text { Bulk Density } \\
\text { TGA, TIC, TOC } \\
\text { ICP (Fusion), GEA, Alpha } \\
\text { IC }\end{array}$ \\
\hline & & Lower $1 / 2$ & $\begin{array}{l}\text { Bulk Density } \\
\text { TGA, DSC, TIC, TOC } \\
\text { ICP (Fusion), GEA, Alpha } \\
\text { IC }\end{array}$ \\
\hline & \multirow[t]{2}{*}{7} & Upper $1 / 2$ & $\begin{array}{l}\text { Bulk Density } \\
\text { TGA, TIC, TOC } \\
\text { ICP (Fusion), GEA, Alpha, Beta, U, }{ }^{89190} \mathrm{Sr} \\
\text { IC } \\
\text { ICP (Acid Digest) }\end{array}$ \\
\hline & & Lower $1 / 2$ & $\begin{array}{l}\text { Bulk Density } \\
\text { TGA, DSC, TIC, TOC } \\
\text { ICP (Fusion), GEA, Alpha } \\
\text { IC }\end{array}$ \\
\hline
\end{tabular}


Table 3-3. Summary of Samples and Analyses. ${ }^{1}$ (6 sheets)

\begin{tabular}{|c|c|c|c|}
\hline Core & Sofrinent & Sequnention & Amilyer \\
\hline \multirow[t]{4}{*}{128} & \multirow[t]{2}{*}{8} & Upper $1 / 2$ & $\begin{array}{l}\text { Bulk Density } \\
\text { TGA, TIC, TOC } \\
\text { ICP (Fusion), GEA, Alpha } \\
\text { IC }\end{array}$ \\
\hline & & Lower $1 / 2$ & $\begin{array}{l}\text { Bulk Density } \\
\text { TGA, DSC, TIC, TOC } \\
\text { ICP (Fusion), GEA, Alpha } \\
\text { IC }\end{array}$ \\
\hline & 9 & Whole & $\begin{array}{l}\text { Bulk Density } \\
\text { TGA, DSC, TIC, TOC } \\
\text { ICP (Fusion), GEA, Alpha } \\
\text { IC }\end{array}$ \\
\hline & \multicolumn{2}{|l|}{ Composite } & $\begin{array}{l}\text { Bulk Density } \\
\text { TGA, DSC, TIC, TOC } \\
\text { ICP (Fusion), GEA, Alpha, Beta, U, Sr } \\
\text { IC } \\
\text { ICP (Acid Digest) }\end{array}$ \\
\hline $\begin{array}{l}\text { Vapor } \\
\text { Tests }\end{array}$ & \multicolumn{2}{|c|}{ Tank Headspace } & $\begin{array}{l}\text { Combustible gas meter readings for flammable } \\
\text { gas }\end{array}$ \\
\hline
\end{tabular}

Notes:

1 (Baldwin 1996a) 
Table 3-4. Analytical Procedures. ${ }^{1}$

\begin{tabular}{|c|c|c|c|}
\hline Wnassis & 6151 Wum & Weporatror Grocedur & 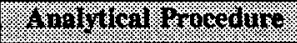 \\
\hline Energetics by DSC & $\begin{array}{l}\text { Mettler } \\
\text { Perkin-Elmer }\end{array}$ & $\mathbf{N} / \mathbf{A}$ & $\begin{array}{l}\text { LA-514-113, Rev. C-1 } \\
\text { LA-514-114, Rev. C-1 }\end{array}$ \\
\hline $\begin{array}{l}\text { Percent water by } \\
\text { TGA }\end{array}$ & $\begin{array}{l}\text { Mettler }^{\mathrm{TM}} \\
\text { Perkin-Elmer }^{\mathrm{TM}}\end{array}$ & N/A & $\begin{array}{l}\text { LA-560-112, Rev. B-1 } \\
\text { LA-514-114, Rev. C-1 }\end{array}$ \\
\hline $\begin{array}{l}\text { Total alpha } \\
\text { activity }\end{array}$ & $\begin{array}{l}\text { Alpha } \\
\text { proportional } \\
\text { counter }\end{array}$ & $\begin{array}{l}\text { Fusion digest on solid } \\
\text { samples, LA-549-141, } \\
\text { Rev. E-0 \& F-0; Direct } \\
\text { on liquid samples }\end{array}$ & LA-508-101, Rev. D-2 \\
\hline Solid bulk density & N/A & N/A & LO-160-103, Rev. B-0 \\
\hline $\begin{array}{l}\text { Liquid specific } \\
\text { gravity }\end{array}$ & N/A & $\mathrm{N} / \mathrm{A}$ & LA-510-112, Rev, C-3 \\
\hline ICP & $\begin{array}{l}\text { Inductively } \\
\text { coupled plasma } \\
\text { spectrometer }\end{array}$ & $\begin{array}{l}\text { LA-549-141, Rev. F-0 } \\
\text { LA-505-159, Rev. D-0 }\end{array}$ & LA-505-151, Rev. D-3 \\
\hline $\mathrm{IC}$ & $\begin{array}{l}\text { Ion } \\
\text { chromatograph }\end{array}$ & $\begin{array}{l}\text { LA-504-101, Revs. } \\
\text { D-0, E-0 }\end{array}$ & LA-533-105, Rev. D-1 \\
\hline TIC & Coulometry & $\mathrm{N} / \mathrm{A}$ & LA-342-100, Rev. C, D \\
\hline TOC & Direct Persulfate & $\mathrm{N} / \mathrm{A}$ & LA-342-100, Rev. C, D \\
\hline${ }^{137} \mathrm{Cs}$ & $\begin{array}{l}\text { Gamma detector } \\
\text { spectrometer }\end{array}$ & $\begin{array}{l}\text { LA-549-141, Revs. } \\
\text { D-0, E-0 }\end{array}$ & LA-548-121, Rev. D-1 \\
\hline${ }^{89 / 90} \mathrm{Sr}$ & $\begin{array}{l}\text { Separation and } \\
\text { counting }\end{array}$ & $\begin{array}{l}\text { LA-549-141, Revs. } \\
\text { D-0, E-0 }\end{array}$ & LA-220-101, Rev. D-0 \\
\hline Total beta & $\begin{array}{l}\text { Separation and } \\
\text { counting }\end{array}$ & $\mathrm{N} / \mathrm{A}$ & LA-508-101, Rev. D-2 \\
\hline Uranium & $\begin{array}{l}\text { Laser } \\
\text { fluorimetry }\end{array}$ & $\begin{array}{l}\text { LA-549-141, Revs. } \\
\text { D-0, E-0 }\end{array}$ & LA-925-009, Rev. A-1 \\
\hline Flammable gas & $\begin{array}{l}\text { Combustible gas } \\
\text { meter }\end{array}$ & N/A & $\begin{array}{l}\text { WHC-IP-030, IH } 1.4 \\
\text { and IH } 2.1\end{array}$ \\
\hline
\end{tabular}

Notes:

Mettler $^{\mathrm{TM}}$ is a registered trademark of Mettler Electronics, Anaheim, California.

Perkin-Elmer ${ }^{\mathrm{TM}}$ is a registered trademark of Perkins Research and Manufacturing Company, Inc., Canoga Park, California.

${ }^{1}$ (Baldwin 1996a) 


\subsection{DESCRIPTION OF THE VAPOR SAMPLING EVENT (1995)}

The tank headspace was vapor-sampled in accordance with Data Quality Objectives for Generic In-Tank Health and Safety Vapors Resolution (Osborne et al. 1995). This DQO directed the collection and analysis of headspace vapor samples to help determine the potential risks of fugitive emissions to tank farm workers. The results have been reported in Headspace Vapor Characterization of Hanford Waste Tank 241-U-109 Results from Samples Collected on August 10, 1995 (Evans et al. 1996). The summarized results are found in Section 4.2.

\subsection{DESCRIPTION OF HISTORICAL SAMPLING EVENT}

Before the 1995/1996 sampling, tank 241-U-109 was last sampled in December 1975 . Since that time, the tank contents have changed substantially due to waste transfers into and out of the tank (see Section 2.3.1). Therefore, the results from the historical sampling event discussed below are not representative of the current tank contents. The data from this sampling event have been included in this report for information only.

A sample was received on November 12, 1975, and analyzed on December 15, 1975. The sample was noted as consisting of small white crystals intermixed with a coarse gray granular material. A description of the technique or procedure used to obtain the sample, and information concerning the sampled riser or sample depth, were not available (Horton 1975a).

Waste analyses were made by dissolving the sample in water. The sample fraction that was not water-soluble was dissolved in $\mathrm{HCl}$. Solids insoluble in water or $\mathrm{HCl}$ were fused with $\mathrm{KOH}$, with the melt then dissolved in concentrated $\mathrm{HCl}$ and diluted with water. Analytical results are in Table C-1 of Appendix C for the supernatant liquid, and Table C-2 for the solids. These analytical results were duplicated in an internal budget report published by Horton (1975b). 
WHC-SD-WM-ER-609 Rev. 0

This page intentionally left blank. 


\subsection{ANALYTICAL RESULTS}

Section 4.0 presents a summary of the analytical results for the December 1995 and January 1996 sampling event. The sampling and analysis parameters governing this event were integrated by, and described in, the SAP (Baldwin 1996b). Extrusion and analysis of the core samples were performed at the Westinghouse Hanford Company 222-S Laboratory.

Data locations for this tank characterization report are displayed in Table 4-1.

Table 4-1. Analytical Data Presentation Tables.

\begin{tabular}{|c|c|}
\hline 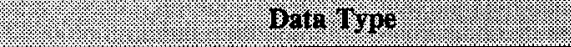 & Houlater hocation \\
\hline Chemical data summary & Table 4-2 \\
\hline Exothermic DSC data summary & Table 4-3 \\
\hline Comprehensive analytical data & Appendix A \\
\hline Hydrostatic head fluid contamination check data & Appendix B \\
\hline 1975 historical sampling data & Appendix C \\
\hline
\end{tabular}

\subsection{DATA PRESENTATION}

The analytical results from the 1995/1996 sampling of tank 241-U-109 were reported in Final Report for Tank 241-U-109, Rotary and Push Mode Cores 123, 124, and 128 (Baldwin 1996a) and have been summarized in Section 4.1. Sections 4.1.1, 4.1.2, 4.1.3, and 4.1.4 present the chemical data, the physical data, the headspace flammability results, and the HHF contamination check results, respectively.

\subsubsection{Chemical Data Summary}

Table 4-2 presents the mean concentration estimates and inventories for the solids results. Data from the three core samples were combined to derive overall means for all analytes except DSC, which does not require calculation of a mean. All information contained in Table 4-2 was taken from the Appendix A tables.

The overall mean presented in Table 4-2 was calculated by first averaging the individual primary and duplicate results for each subsegment to obtain a subsegment mean. The DSC, TGA, TIC, and TOC analyses each had several triplicate runs conducted, and these were averaged into the calculation of the particular subsegment means. The subsegment means 
within a given segment were then averaged to obtain a segment mean, the segment means within a given core were averaged to obtain a core mean, and finally, the three core means were averaged to derive the overall tank mean. Not all of these steps are necessary for each analyte or for each subsegment, but the procedure to be followed is the same. The overall mean and projected inventories listed in Table 4-2 were considered either detected or nondetected $(<)$ values. When fifty percent or more of the individual primary and duplicate measurements had detected results, the overall mean was reported as a detected value. Conversely, when greater than half of the individual primary and duplicate measurements had nondetected results, the overall mean was reported as a nondetected value. The implication associated with nondetected numbers as quantitative observations results in the mean concentrations and inventory estimates being biased. The magnitude of the bias is unknown.

The third column displays the relative standard deviation (RSD) of the mean, defined as the standard deviation of the mean divided by the mean and multiplied by 100 . The RSDs were determined by using standard analysis of variance (ANOVA) statistical techniques (nested models), and were computed only for those analytes that had detected means.

The projected inventories listed in the fourth column were obtained by multiplying the overall mean by the total waste volume of $1,753 \mathrm{~kL}$ (463 kgal), the overall tank density of $1.67 \mathrm{~g} / \mathrm{mL}$, and the appropriate conversion factors.

Overall tank means and inventories for the drainable liquid sample were not included in Table 4-2 because of HHF contamination. The results are included in the Appendix A tables for information only.

\subsubsection{Physical Data Summary}

Thermal analyses and density measurements were performed on the tank 241-U-109 core samples to satisfy the requirements of the safety screening DQO (Dukelow et al. 1995). The organic complexant safety DQO (Tumer et al. 1995), the organic safety test plan (Meacham 1995) and historical model evaluation DQO (Simpson and McCain 1995) required thermal analyses only.

4.1.2.1 Thermogravimetric Analysis. During a TGA, the mass of a sample is measured while its temperature is increased at a constant rate. Nitrogen is passed over the sample during the heating to remove any released gases. Any decrease in the weight of a sample represents a loss of gaseous matter from the sample either through evaporation or through a reaction that forms gas phase products. The moisture content is estimated by assuming that all TGA sample weight loss up to a certain temperature (typically $150^{\circ} \mathrm{C}$ ) is due to water evaporation. TGA was performed on homogenized solid samples and directly on drainable liquids. 
WHC-SD-WM-ER-609 Rev. 0

Table 4-2. Chemical Data Summary for Tank 241-U-109.

\begin{tabular}{|c|c|c|c|}
\hline ( & 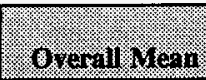 & (Mequ) & 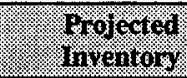 \\
\hline MLW W & 189 & $\%$ & $8 \%$ \\
\hline Aluminum & 19,700 & 32.6 & 57,700 \\
\hline Bismuth & $<2,110$ & $\mathrm{n} / \mathrm{a}$ & $<6,180$ \\
\hline Calcium & $<2,110$ & $\mathrm{n} / \mathrm{a}$ & $<6,180$ \\
\hline Chromium & 3,690 & 14.1 & 10,800 \\
\hline Iron & $<1,420$ & $\mathrm{n} / \mathrm{a}$ & $<4,160$ \\
\hline Manganese & $<216$ & $\mathrm{n} / \mathrm{a}$ & $<632$ \\
\hline Nickel & $<421$ & $\mathrm{n} / \mathrm{a}$ & $<1,230$ \\
\hline Phosphorus & $<8,000$ & $\mathrm{n} / \mathrm{a}$ & $<23,400$ \\
\hline Silicon & $<1,150$ & $\mathrm{n} / \mathrm{a}$ & $<3,370$ \\
\hline Sodium & $2.21 E+05$ & 3.0 & $6.47 \mathrm{E}+05$ \\
\hline Uranium & $<10,600$ & $\mathrm{n} / \mathrm{a}$ & $<31,000$ \\
\hline MUONS & 2. & \%. & . \\
\hline Nitrate & $3.08 E+05$ & 12.8 & $9.02 \mathrm{E}+05$ \\
\hline 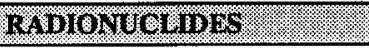 & 1640 & $\%$ & (2. \\
\hline Total alpha & 0.0371 & 20.9 & 109 \\
\hline Total beta & 126 & 12.1 & $3.69 E+05$ \\
\hline${ }^{137} \mathrm{Cs}$ & 112 & 9.8 & $3.28 \mathrm{E}+05$ \\
\hline${ }^{89 / 90} \mathrm{Sr}$ & 6.89 & 15.4 & 20,200 \\
\hline CAREO & 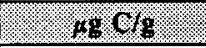 & $8.7 \%$ & 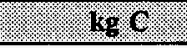 \\
\hline Total inorganic carbon & 7,550 & 12.0 & 22,100 \\
\hline Total organic carbon & 3,600 & 7.8 & 10,500 \\
\hline 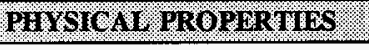 & 鄗 & 8. & 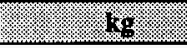 \\
\hline Weight percent water & 23.7 & 13.6 & $6.94 \mathrm{E}+05$ \\
\hline Density $(\mathrm{g} / \mathrm{mL})$ & 1.67 & 1.6 & $\mathrm{n} / \mathrm{a}$ \\
\hline
\end{tabular}

Notes:

$$
\begin{aligned}
& \mathbf{n} / \mathbf{a}=\text { not applicable. } \\
& { }^{1} \text { (Baldwin 1996a) }
\end{aligned}
$$


The TGA results for tank 241-U-109 are presented in Appendix A, Table A-25. Again, the weight loss was attributed to the evaporation of water. The overall weight percent water mean estimate for the solids was 27.7 percent. Several of the individual samples were below the organic complexant DQO decision threshold of 17 weight percent water. Because the minimum exothermic energy necessary to support a propagating reaction is a change in enthalpy of $480 \mathrm{~J} / \mathrm{g}$ (Turner et al. 1995), and because none of the sample results exhibited an exothermic reaction of this magnitude, the low weight percent water values were not a concern.

4.1.2.2 Differential Scanning Calorimetry. During a DSC analysis, heat absorbed or emitted by a substance is measured while the temperature of the substance is increased at a constant rate. While the substance is being heated, nitrogen is passed over the waste material to remove any gases being released. The onset temperature for an endothermic (characterized by or causing the absorption of heat) or an exothermic (characterized by or causing the release of heat) event is determined graphically. The DSC results (wet basis) are presented in Appendix A, Table A-26. The peak temperature and maximum enthalpy changes are given for each sample.

Table 4-3 lists all of the samples that had one or more exothermic reactions recorded. As can be seen, none of the samples exceeded the safety screening and organic complexant safety DQO decision threshold of $480 \mathrm{~J} / \mathrm{g}$, or the organic safety test plan decision threshold of $1,200 \mathrm{~J} / \mathrm{g}$. The highest individual sample result was $301.9 \mathrm{~J} / \mathrm{g}$ (dry weight). The highest one-sided 95 percent confidence interval upper limit on the mean was $493.4 \mathrm{~J} / \mathrm{g}$ (dry weight), slightly above the safety screening and organic complexant safety DQO decision threshold. However, this result was attributed to variability in the data (Baldwin 1996a).

4.1.2.3 Density. Density measurements were performed on all solids subsegments. The subsegment level results ranged from a high of $1.97 \mathrm{~g} / \mathrm{mL}$ from quarter segment $\mathrm{C}$ of segment 9 , core 123 , to a low of $1.24 \mathrm{~g} / \mathrm{mL}$ from the upper half of segment 3 , core 123 . The average density for the tank was $1.67 \mathrm{~g} / \mathrm{mL}$. This compares with a composite average of $1.75 \mathrm{~g} / \mathrm{mL}$. The results are presented in Appendix A, Table A-27.

\subsubsection{Headspace Flammability Screening Results}

As required by the safety screening DQO (Dukelow et al. 1995) and requested in the SAP (Baldwin 1996b), the tank headspace was sampled and analyzed for the presence of flammable gases before core sampling. This was especially crucial considering that tank 241-U-109 is on the Flammable Gas Watch List. The analytical results showed a maximum of 5 percent of the LFL, well below the 25 percent decision threshold. 


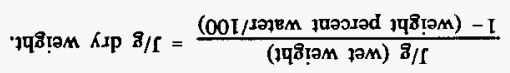

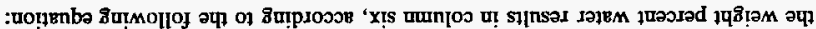

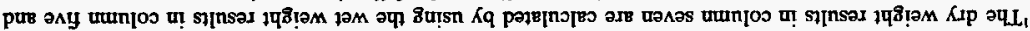

:sอ10N

\begin{tabular}{|c|c|c|c|c|c|c|c|}
\hline \multirow[b]{3}{*}{$\nabla^{\circ} 9 S I$} & \multirow[b]{3}{*}{8.09} & $\varepsilon 0 L$ & \multirow[b]{3}{*}{$20^{\circ} I \varepsilon$} & 0580 & $\varepsilon$ & \multirow[b]{3}{*}{$y_{1}$ гомот } & \multirow[b]{3}{*}{$8: 8 Z 1$} \\
\hline & & $\tau \cdot \tau I I$ & & $0 \nabla^{\circ} \angle L$ & $\tau$ & & \\
\hline & & 0 & & 0 & $\mathrm{I}$ & & \\
\hline \multirow[b]{2}{*}{$\tau \cdot \varepsilon \neq I$} & \multirow[b]{2}{*}{$8^{\circ} 2 \mathcal{E} I$} & $\nabla^{*} \nabla \varepsilon I$ & \multirow[b]{2}{*}{$\angle S O D$} & $06.6 \mathrm{~L}$ & 2 & \multirow[b]{2}{*}{$z_{1}$ IวMOT } & \multirow[b]{2}{*}{$L: 8 Z \mathrm{ZI}$} \\
\hline & & $I^{\circ} I E I$ & & $06 \angle L$ & I & & \\
\hline \multirow[b]{2}{*}{$9.8 \mathrm{ZI}$} & \multirow[b]{2}{*}{ 8.EII } & I9II & \multirow[b]{2}{*}{$I \mathcal{E}^{\cdot} \mathcal{E E}$} & $0 t^{\circ} \angle L$ & 2 & \multirow[b]{2}{*}{$z / \mathrm{I}$ Іамот } & \multirow[b]{2}{*}{$9: 8 \mathrm{ZI}$} \\
\hline & & DIII & & $O E \div L$ & I & & \\
\hline \multirow[b]{2}{*}{$\varepsilon \cdot I t$} & \multirow[b]{2}{*}{$S \angle I$} & $\pm Z^{\prime} I Z$ & \multirow[b]{2}{*}{$29^{\circ} \angle 2$} & $08^{\circ} \varepsilon I$ & $z$ & \multirow[b]{2}{*}{ วГочM } & \multirow[b]{2}{*}{$5: 8 Z \mathrm{I}$} \\
\hline & & $O L^{\circ} \mathcal{E} I$ & & 0068 & I & & \\
\hline \multirow[b]{2}{*}{$t \varepsilon 6 t$} & \multirow[b]{2}{*}{ 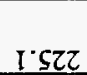 } & $9.28 \mathrm{I}$ & \multirow[b]{2}{*}{$L 99 t$} & $O \varepsilon^{\circ} \angle 6$ & $z$ & \multirow[b]{2}{*}{$2 / 1$ IәMOI } & \multirow[b]{2}{*}{$7: 82 I$} \\
\hline & & $9 \div 92$ & & $9 \cdot z \neq I$ & I & & \\
\hline \multirow[b]{3}{*}{$8^{\cdot} \mathcal{E} t$} & \multirow[b]{3}{*}{$\varepsilon L I$} & $8^{\circ} 0 \varepsilon$ & \multirow[b]{3}{*}{$\mathrm{I} 0^{\circ} \mathrm{OE}$} & OS'IZ & $\varepsilon$ & \multirow[b]{3}{*}{ ग०४М } & \multirow[b]{3}{*}{$\mathrm{I}: 8 \mathrm{ZI}$} \\
\hline & & $\tau \cdot I Z$ & & $08^{\circ}+I$ & 2 & & \\
\hline & & 0 & & 0 & I & & \\
\hline & & $L \cdot I S I$ & & $0 I \div 6$ & $z$ & & \\
\hline $6 \cdot 6 \angle I$ & t.9tI & $I^{\circ} I t I$ & $86^{\circ} S E$ & $0 \varepsilon: 06$ & $\mathrm{I}$ & $z / \mathrm{I}$ IOMOT & $9: \bullet z I$ \\
\hline & & $0<z$ & & $2 \cdot 26 I$ & $z$ & & \\
\hline 9IE & $\nabla 192$ & $\angle Z S Z$ & 18.82 & 08I & I & $z / 1$ sədd $\Omega$ & $9: \diamond Z I$ \\
\hline & & $6.10 E$ & & $\varepsilon \angle E Z$ & $z$ & & \\
\hline$I^{\circ} L L \varepsilon$ & $8^{\circ} \angle 8 Z$ & $9 \cdot \varepsilon L Z$ & $I t^{\circ} I Z$ & SIZ & I & $z / 1$ IәMOI & $s: p z I$ \\
\hline & & $E: L S$ & & $O L ' S E$ & $z$ & & \\
\hline S8ZI & $6 \cdot \mathcal{E} t$ & S.OE & $\angle 9^{\circ} \angle \mathcal{E}$ & $00.6 \mathrm{I}$ & I & $\forall$ & $6: E Z I$ \\
\hline & & $8 \angle L$ & & 06.25 & $\varepsilon$ & & \\
\hline & & I.OEL & & $05^{\circ} 88$ & $z$ & & \\
\hline$\tau \angle D I$ & EOI & IOI & $86^{\circ} I \mathcal{E}$ & $0<89$ & I & $y_{1}$ Iәмот & 9:EZI \\
\hline $3.1 \%$ \% & 811 & 8 & (2) & Wo & 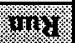 & $10010 \%$ & 10110\% \\
\hline$(6,14,901)$ & 19314 & /19. & 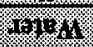 & (.) 10 & & & $3.10 \%$ \\
\hline (1) & (14. & $4 \%$ & 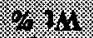 & 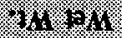 & & & \\
\hline 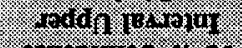 & 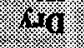 & 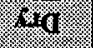 & 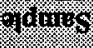 & & & & \\
\hline 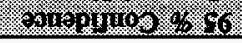 & & & & & & & \\
\hline
\end{tabular}

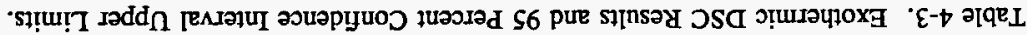




\subsubsection{Hydrostatic Head Fluid Contamination Check}

Hydrostatic head fluid was used as wash water during the 1995/1996 core sampling event for tank 241-U-109. Lithium bromide was added to the HHF as a tracer, and its presence in the core samples would indicate contamination by the HHF. Because HHF is essentially water, the significance of any contamination is the possibility of a bias in the weight percent water analytical results and in the analytical results for all other analytes. This check, through analyses for lithium and bromide, was prescribed by the SAP (Baldwin 1996b). The analytical results for lithium and bromide were not included in Table 4-2 because they are not constituents of the tank waste. The tabulated results are reported in Appendix B.

Bromide was detected in the solids and drainable liquid samples of core 124 , segment 3 , and in the solids results from core 128, segment 5 . However, lithium was not detected in either of these two segments (or in any others). The absence of lithium has been observed in other sampling events and is believed to be due to the precipitation of non-soluble lithium salts. Using HHF correction calculations for bromide, it was found that over 50 percent $^{1}$ of the water present in the solids and drainable liquid portions of core 124, segment 3 were from HHF. Based on this evidence (along with the higher weight percent water measured for this segment), and the fact that this was the only segment to have drainable liquid, these weight percent water results were not considered valid, and were not utilized in the overall mean estimates or any other evaluations. A close examination of the core 124, segment 3 solids data for detected analytes (such as aluminum, sodium, total alpha activity, TOC, and especially density), does not reveal any obvious discrepancies with the analytical results from neighboring segments (see Appendix A tables). Therefore, all solids data (except weight percent water) from this segment were retained. The core 124, segment 3 drainable liquid result is reported in the Appendix A tables for information only. The HHF correction calculations for core 128 , segment 5 yielded a weight percent water result of 27.62 , compared with the analytical result of 35.02 percent. Since this was less than a 50 percent difference ( 21 percent), all data from this segment were retained, and the corrected percent water value of 27.62 was utilized in all data evaluations (Baldwin 1996a).

\subsection{DATA SUMMARY OF 1995 VAPOR SAMPLING}

Vapor samples taken from the headspace of the waste storage tank 241-U-109 were obtained to characterize the vapors present in the tank headspace, and to support safety evaluations and tank farm operations. The results include air concentrations of selected inorganic and organic analytes and grouped compounds from samples obtained by Westinghouse Hanford Company and provided for analysis to the Pacific Northwest National Laboratory (PNNL).

'If greater than 50 percent of the water present is from HHF, then the sample must be considered suspect (Winkelman 1996). 
Analyses were performed by the vapor analytical laboratory at PNNL. A summary of the inorganic analytes, permanent gases, and total non-methane hydrocarbons is listed in Table 4-4.

Table 4-4. Summary Results of Samples to Characterize the Headspace of Tank 241-U-109 on August 10, 1995.

\begin{tabular}{|c|c|c|c|c|}
\hline (3.1.6\% & Singen & (2) & 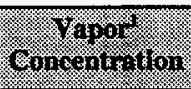 & 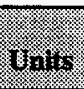 \\
\hline \multirow[t]{4}{*}{ Inorganic Analytes ${ }^{2}$} & \multirow[t]{4}{*}{ Sorbent traps } & $\mathrm{NH}_{3}$ & $577 \pm 20$ & ppmv \\
\hline & & $\mathrm{NO}_{2}$ & $\leq 0.06$ & ppmv \\
\hline & & NO & $\leq 0.06$ & ppmv \\
\hline & & $\mathrm{H}_{2} \mathrm{O}$ & $14.8 \pm 0.4$ & $\mathrm{mg} / \mathrm{L}$ \\
\hline \multirow[t]{5}{*}{ Permanent Gases } & \multirow{5}{*}{$\begin{array}{l}\text { SUMMA }^{\mathrm{TM}} \\
\text { canister }\end{array}$} & $\mathrm{CO}_{2}$ & $<25$ & ppmv \\
\hline & & $\mathrm{CO}$ & $<25$ & ppmv \\
\hline & & $\mathrm{CH}_{4}$ & $<25$ & ppmv \\
\hline & & $\mathrm{H}_{2}$ & 748 & ppmv \\
\hline & & $\mathrm{N}_{2} \mathrm{O}$ & 868 & ppmv \\
\hline $\begin{array}{l}\text { Total non-methane } \\
\text { hydrocarbons } \\
(\mathrm{TO}-12)\end{array}$ & $\begin{array}{l}\text { SUMMA }^{\mathrm{TM}} \\
\text { canister }\end{array}$ & Hydrocarbons & 9.25 & $\mathrm{mg} / \mathrm{m}^{3}$ \\
\hline \multirow{3}{*}{$\begin{array}{l}\text { Volatile organics } \\
\text { (TO-14) }\end{array}$} & \multirow{3}{*}{$\begin{array}{l}\text { SUMMA }^{\mathrm{TM}} \\
\text { canister }\end{array}$} & Methyl alcohol & 0.408 & ppmv \\
\hline & & Trichlorofluoromethane & 0.350 & ppmv \\
\hline & & Acetone & 0.223 & ppmv \\
\hline \multirow{3}{*}{$\begin{array}{l}\text { Semi-volatile } \\
\text { organics } \\
\text { (PNL-TVP-10) }\end{array}$} & \multirow[t]{3}{*}{ Sorbent traps } & $\begin{array}{l}\text { Ethane, 1-chloro-1, } \\
\text { 1-difluoro- }\end{array}$ & 0.733 & ppmv \\
\hline & & Ethanol & 0.432 & ppmv \\
\hline & & Trichlorofluoromethane & 0.330 & ppmv \\
\hline
\end{tabular}

Notes:

${ }^{1}$ Vapor concentrations were determined using sample-volume data provided by Westinghouse Hanford Company and are based on averaged data.

${ }^{2}$ Inorganic analyte concentrations are based on dry tank air at standard temperature and pressure. 
WHC-SD-WM-ER-609 Rev. 0

This page intentionally left blank. 


\subsection{INTERPRETATION OF CHARACTERIZATION RESULTS}

The purpose of this chapter is to discuss the overall quality and consistency of the current sampling results for tank 241-U-109, and to assess and compare these results against historical information and program requirements.

\subsection{ASSESSMENT OF SAMPLING AND ANALYTICAL RESULTS}

This section evaluates sampling and analysis factors that may impact interpretation of the data. These factors are used to assess the overall quality and consistency of the data and to identify any limitations in the use of the data.

\subsubsection{Field Observations}

The safety screening (Dukelow et al. 1995), organic complexant safety (Turner et al. 1995), and historical model evaluation (Simpson and McCain 1995) DQOs all required vertical profiles of the waste from at least two widely-spaced risers. This requirement was fulfilled, allowing a spatial examination of the analyte concentrations. Contamination of the core 124, segment 3 sample by HHF resulted in all drainable liquid data and the solids weight percent water data from this segment being excluded from the mean calculations and other evaluations. HHF intrusion of core 128, segment 5 resulted in the adjustment of the weight percent water value. No further anomalies that might limit the use of the data were noted.

\subsubsection{Quality Control Assessment}

The usual QC assessment includes an evaluation of the appropriate standard recoveries, matrix spike recoveries, duplicate analyses, and blanks that are performed in conjunction with the chemical analyses. All the pertinent QC tests were conducted on the 1995/1996 core samples, allowing a full assessment regarding the accuracy and precision of the data. As indicated in the SAP, the specific criteria for all QC checks were governed by the Hanford Analytical Services Quality Assurance Plan (DOE 1995). QC results outside these criteria are identified by superscripts in the Appendix A and Appendix B tables for all analytes. A summary of the QC results is presented below.

The standard and spike recovery results provide an estimate of the accuracy of the analysis. If a standard or spike recovery is above or below the given criterion, then the analytical results may be biased. All standard recoveries were within the defined criteria with the exception of one of nine total beta results, which was slightly above the limit. Total alpha activity had 6 of 39 matrix spikes below the criterion of 75 to 125 percent recovery. This was probably due to large sample sizes, which resulted in high amounts of solid material on the sample mount and possible self-shielding (Baldwin 1996a). TOC had just one of 18 
results outside of the limit. For sodium, half of the spike recoveries for the fusion-digestion results were below the criterion, and the three conducted on the acid-digested results were well above the criterion. These poor recoveries were probably due to the high dilutions required to measure the large sodium concentrations. The few spike recovery deviations for the remainder of the analytes were very minor.

Analytical precision is estimated by the relative percent difference (RPD), which is defined as the absolute value of the difference between the primary and duplicate samples, divided by their mean, times 100 . Total alpha activity had 16 of 39 RPDs above the criterion, probably due to low sample activities and possible self-shielding. Reruns were not requested because the largest sample mean was 250 times below the decision criteria threshold and the results were near the detection limit. Regardless, the spike recovery and RPD deviations for total alpha activity were not substantial enough to affect the criticality evaluation. Six of the 13 samples with exothermic reactions had RPDs above the criterion. This was not unusual given the small sample sizes and possible sample heterogeneity problems. Several other analytes displayed minor RPD deviations, likely due to sample concentrations near the detection limit that adversely impacted the reproducibility of the results. Finally, none of the samples exceeded the criteria for preparation blanks; thus, contamination was not a problem for any of the analytes.

In summary, practically all of the QC results were within the boundaries specified in DOE (1995). The few discrepancies noted should not impact either the validity or the use of the data.

\subsubsection{Data Consistency Checks}

The comparison of results from different analytical methods can help to assess the consistency and quality of the data. Close agreement between the two methods strengthens the credibility of both results, whereas poor agreement brings the reliability of the data into question. Sufficient anion data was not requested in the SAP for calculation of mass and charge balances. A comparison of the total beta activity with the activities of the individual beta emitters was made using the analytical mean composite level results for the total beta measurement, and the activities of ${ }^{89 / 90} \mathrm{Sr}$ and ${ }^{137} \mathrm{Cs}$ given in the Appendix $\mathrm{A}$ tables. The sum of the beta emitters was calculated as follows:

$$
\text { Sum of beta emitters }=\left(2 *{ }^{89 / 90} \mathrm{Sr}+{ }^{137} \mathrm{Cs}\right)
$$

Because ${ }^{89 / 90} \mathrm{Sr}$ is in equilibrium with its daughter product ${ }^{90} \mathrm{Y}$, the ${ }^{89 / 90} \mathrm{Sr}$ activity must be multiplied by 2 to account for all of the beta emitters. This comparison is shown in Table 5-1. The activities of the two methods compared well, yielding a ratio of 1.08 . 
Table 5-1. Comparison of Total Beta Activity with the Sum of ${ }^{89 / 90} \mathrm{Sr}$ and ${ }^{137} \mathrm{Cs}$ Activities.

\begin{tabular}{|c|c|c|}
\hline Amalee & Orerail Mean $(f$ Cyg) & 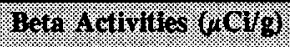 \\
\hline${ }^{89 / 90} \mathrm{Sr}$ & 9.70 & 19.4 \\
\hline${ }^{137} \mathrm{Cs}$ & 122 & 122 \\
\hline \multicolumn{2}{|l|}{ Sum of beta emitters } & 141 \\
\hline \multicolumn{2}{|l|}{ Total beta activity } & 131 \\
\hline \multicolumn{2}{|l|}{ Ratio } & 1.08 \\
\hline
\end{tabular}

\subsection{COMPARISON OF HISTORICAL WITH ANALYTICAL RESULTS}

Before the 1995/1996 core sampling event, the most recent sampling of tank 241-U-109 took place in November 1975. Due to multiple transfers in the following years, no valid comparison between any the 1995/1996 and 1975 results is possible. The 1975 results are reported in Appendix C for information only.

\subsection{TANK WASTE PROFILE}

According to the estimate of Hanlon (1996), the $449 \mathrm{~cm}$ (176.7 in.) of waste in tank $241-\mathrm{U}-109$ consists of $72 \mathrm{~kL}$ (19 kgal) of supernatant covering $1,499 \mathrm{~kL}$ (396 kgal) of saltcake and $182 \mathrm{~kL}$ (48 kgal) of sludge. The saltcake and sludge layers include $617 \mathrm{~kL}$ (163 kgal) of drainable interstitial liquid. The TLM estimates were similar to those of Hanlon (1996), but divided the saltcake layer into roughly equal portions of saltslurry and saltcake, as well as dividing the bottom sludge layer into equal portions of CRW1 and MW (see Figure 2-3).

The photographic montage of the waste surface showed a mixture of solids and liquids, and possibly orange-colored saltcake floating on the liquid.

The visual descriptions of the samples indicated some variations in color between segments, with medium gray being predominate, but also with some blue, brown, white, yellow, or black. The texture varied from wet and slushy saltcake to dry and granular saltcake. The descriptions comparing the segments where the two saltcake layers would be expected were quite similar. The bottom segment from the three cores coincides with the two thin sludge layers predicted by the TLM (Agnew 1996a), and their visual descriptions did differ from the other segments, but were not consistent with each other. Based on all of the above information, the tank waste appears to be somewhat heterogeneous. 
Standard statistical ANOVA (analysis of variance) models were fit to the 1995/1996 core, segment, and subsegment data. The results from these models can be used to judge the vertical and horizontal variability in analyte concentrations. Nested random-effects ANOVA models were fit to the analytical data, provided that at least 50 percent of the individual primary and duplicate measurements were above detection limits.

The p-value, from the ANOVA models, is compared to a standard significance level $(\alpha=0.05$ ). If it is less than 0.05 , then the analyte means are significantly different from each other. However, if a $p$-value is greater than 0.05 , the analyte means are not significantly different from each other. In the following paragraphs, the $\mathrm{p}$-values are in parentheses.

Nine analytes had subsegment data from multiple core samples. The results of the ANOVA indicated that there were significant differences in the mean concentration between subsegments for all nine analytes (all p-values $<0.0001$ ).

Fifteen analytes had segment data from multiple core samples. The results from five of the analytes were based on an acid digestion and the results from the other 10 analytes were based on a fusion digestion of subsamples. Based on the acid digestion results, there were significant differences in the mean concentrations between segments for 4 of the 5 analytes [aluminum $(<0.001)$, chromium $(<0.001)$, total beta $(<0.001)$, and ${ }^{89 / 90} \mathrm{Sr}(<0.001)$ ]. For the fusion-digestion results, there were significant differences in mean concentrations between the segments for 4 of the 10 analytes [nitrate $(<0.001)$, TIC $(0.012)$, total alpha activity (0.006), and $\left.{ }^{137} \mathrm{Cs}(0.004)\right]$.

In addition, for the segment level data, there were no significant differences in the mean analyte concentration between the three core samples based on the acid-digestion results. For the fusion-digestion results, there were significant differences in mean concentration between the three core samples for chromium $(0.007)$ and weight percent water $(0.032)$.

An ANOVA model was also fit to concentration data on 16 analytes based on core composite samples. There were significant differences between the mean analyte concentrations, based on core composite samples, for 10 analytes [aluminum, acid-digestion (0.004); aluminum, fusion-digestion (0.025); chromium, fusion-digestion (0.003); sodium, fusion-digestion $(0.001)$; nitrate $(0.003)$; TOC $(0.040)$; weight percent water $(0.016)$; total beta $(0.001) ;{ }^{137} \mathrm{Cs}$ $(<0.001)$; and $\left.{ }^{89 / 30} \mathrm{Sr}(0.002)\right]$.

In summary, the Hanlon (1996) estimates, the TLM, the photo montage, the visual descriptions of the samples, and the statistical results all indicated a certain degree of vertical heterogeneity. The evidence for horizontal heterogeneity is less pronounced than that for vertical heterogeneity. Data from 31 analytes were evaluated. There were significant differences in mean concentrations between core samples for only 12 of the analytes (39 percent). In addition, the differences in the visual descriptions of the samples were less pronounced between cores than they were between segments. 


\subsection{COMPARISON OF TRANSFER HISTORY WITH ANALYTICAL RESULTS}

The HTCE (Agnew 1996a) estimates of the tank contents are compared with the analytical results from the 1995/1996 sampling event in Table 5-2. The HTCE values are generated using a combination of several data sources, as described in Section 2.3.2. Each of these data sources contains assumptions and/or other factors (such as transfers of an unknown waste type into the tank) that may impact the modeled concentrations presented in the HTCE. Since the HTCE values have not been validated, these comparisons are presented for information only. The results compared quite favorably given the uncertainties inherent in the HTCE values.

Table 5-2. Comparison of HTCE with 1995/1996 Analytical Results for Tank 241-U-109.

\begin{tabular}{|c|c|c|c|}
\hline Analyte & Model Estimate & 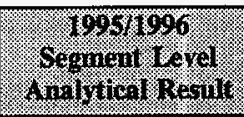 & 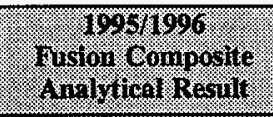 \\
\hline MUUA WS & . & (7) & 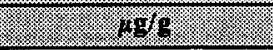 \\
\hline Aluminum & 38,200 & 19,700 & 19,700 \\
\hline Chromium & 2,090 & 3,690 & 3,590 \\
\hline Sodium & $1.91 \mathrm{E}+05$ & $2.21 \mathrm{E}+05$ & $2.27 \mathrm{E}+05$ \\
\hline ANIONS: & I9 & $108 / 8$ & 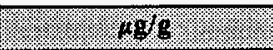 \\
\hline Nitrate & $2.13 \mathrm{E}+05$ & $3.08 \mathrm{E}+05$ & $3.31 \mathrm{E}+05$ \\
\hline RADIONUCIIOES & $1.101 \mathrm{~g}$ & 1948 & I G19 \\
\hline${ }^{137} \mathrm{Cs}$ & 167 & 112 & 122 \\
\hline${ }^{89190} \mathrm{Sr}$ & 87.7 & $6.89^{1}$ & 9.70 \\
\hline CARBOA & $12 \mathrm{gCg}$ & $7.1 .8 \mathrm{Clg}$ & \% \\
\hline Total inorganic carbon & 4,480 & 7,550 & 8,340 \\
\hline Total organic carbon & 10,200 & 3,600 & 3,780 \\
\hline \multicolumn{4}{|c|}{ TTYSTCAI PROPERTIES } \\
\hline Weight percent water & $27.3 \%$ & $23.7 \%$ & $25.3 \%$ \\
\hline Density & $1.71 \mathrm{~g} / \mathrm{mL}$ & $1.67 \mathrm{~g} / \mathrm{mL}$ & $1.75 \mathrm{~g} / \mathrm{mL}$ \\
\hline
\end{tabular}

Note:

${ }^{1}$ Results from two segments only, from each of the three cores. See Appendix A, Table A-20. 


\subsection{EVALUATION OF PROGRAM REQUIREMENTS}

The $1995 / 1996$ core sampling event was governed by three DQOs and a test plan. The safety screening DQO (Dukelow et al. 1995) lists requirements for examining the waste in each Hanford underground waste tank to identify safety problems, and to evaluate the tank for placement on a Watch List or to verify current Watch List status. Tank 241-U-109 is currently on the Flammable Gas Watch List. The organic complexant safety DQO (Tumer et al. 1995) addresses the possibility of an exothermic reaction between organic complexants and precipitated nitrate or nitrite salts. The organic safety test plan (Meacham 1995) examines the flammability potential of tanks containing entrained organic solvents. Finally, the historical model evaluation DQO (Simpson and McCain 1995) attempts to acquire information through selective tank sampling to quantify the errors associated with the predictions for the waste composition. These issues were integrated by the SAP (Baldwin 1996b) into a list of required analytical tests and their respective decision criteria thresholds.

Section 5.5 discusses the requirements of each DQO and the test plan, and compares the analytical data to their decision criteria thresholds. Section 5.5.1 discusses each safety issue as identified in the safety screening and organic complexant safety DQOs and the organic safety test plan, as well as evaluating the estimated tank heat load. Section 5.5.2 examines the historical model evaluation.

\subsubsection{Safety Evaluation}

The safety screening DQO requirement that vertical profiles of the waste be obtained from at least two widely-spaced risers was met. Of the five primary analyses required by this DQO, three have decision criteria thresholds which, if exceeded, could warrant further investigation to ensure tank safety. These three analyses include DSC to evaluate the fuel content, total alpha activity to determine the criticality potential, and a determination of the flammability of the gases in the tank headspace.

Regarding the organic complexant safety DQO, the optimum number of waste profiles required is based on information such as historical sampling or prior sampling activities. If specific information is not available, two vertical profiles will be obtained from widely-spaced risers. Tank 241-U-109 was evaluated in accordance with this DQO because the tank was identified as possibly containing $>3$ weight percent TOC by a review of waste transfer records (Turner et al. 1995). The primary analyses required by this DQO are DSC, TGA to determine the moisture content, and a TOC analysis to estimate its contribution to the total fuel content. Decision criteria thresholds were also established by the DQO for these analytes. 


\begin{tabular}{|c|c|c|c|}
\hline Т 1 T әप ग० \% $\mathrm{s}$ & 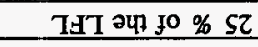 & 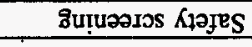 & 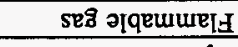 \\
\hline 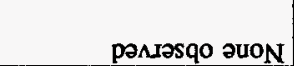 & 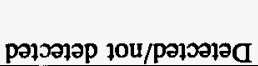 & 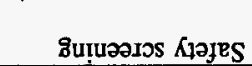 & 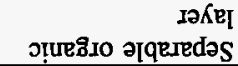 \\
\hline 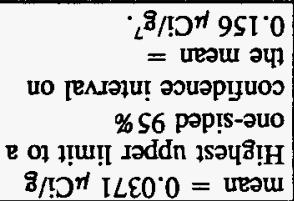 & $9^{8} / \mathrm{D}^{n}$ It & 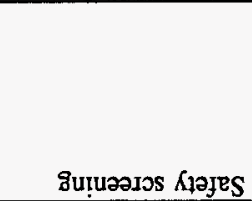 & 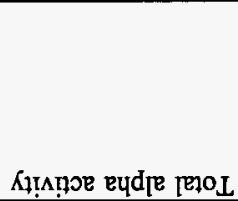 \\
\hline \multirow{2}{*}{$\begin{array}{l}s^{\%} 1 \mathrm{1M} 8 \mathcal{E}^{\circ} 9=\mathrm{MOI} \\
\%+\mathrm{M} L^{\circ} \varepsilon Z=\text { UEวW }\end{array}$} & 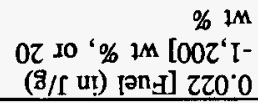 & 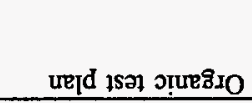 & \multirow{2}{*}{ 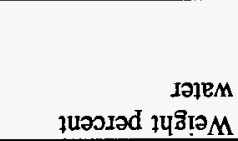 } \\
\hline & $\%$ IM LI & 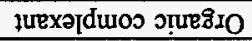 & \\
\hline \multirow{2}{*}{ 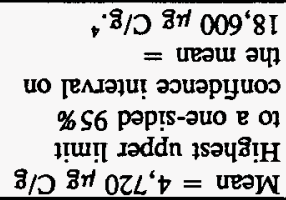 } & $8 / 08 n 000^{\prime} \mathrm{st}$ & 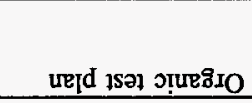 & \multirow[b]{2}{*}{ 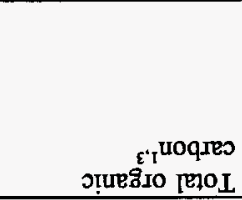 } \\
\hline & $8 / 2817000^{\circ} 0 \varepsilon$ & 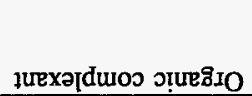 & \\
\hline \multirow{3}{*}{ 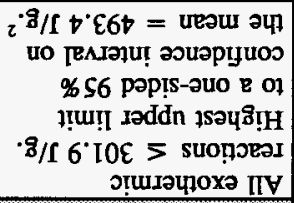 } & $8 / f 00 Z^{6} I$ & 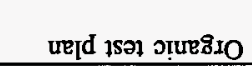 & \multirow[b]{3}{*}{ 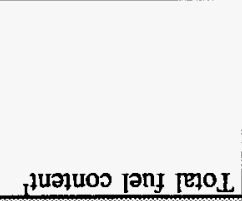 } \\
\hline & $3 / 1080$ & 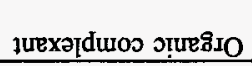 & \\
\hline & $3 / 1080$ & 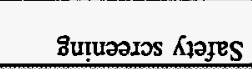 & \\
\hline HIIs) & 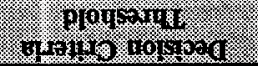 & 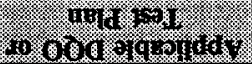 & 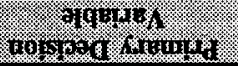 \\
\hline
\end{tabular}

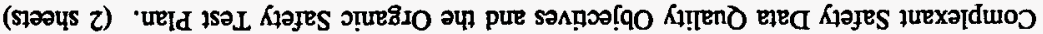

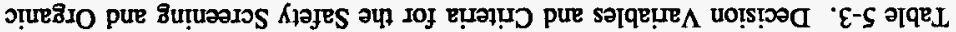

"นए[d

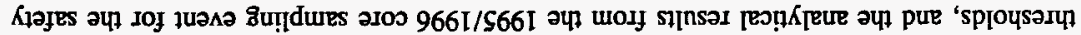

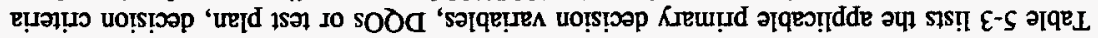

TOLL PUR 'YDL 'JSA әpniout

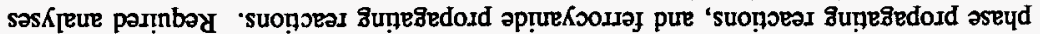

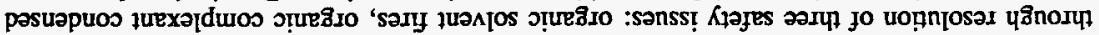

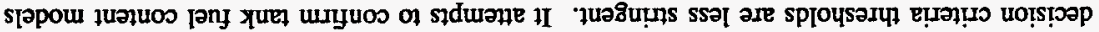

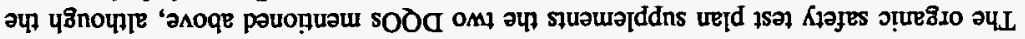


Table 5-3. Decision Variables and Criteria for the Safety Screening and Organic Complexant Safety Data Quality Objectives and the Organic Safety Test Plan. (2 sheets)

Notes:

'All decision criteria thresholds and analytical results are given as dry weight values.

${ }^{2}$ This is the only 95 percent confidence interval upper limit that exceded the decision threshold of $480 \mathrm{~J} / \mathrm{g}$. It was located in the lower half of core 128 , segment 4 . This value was most likely above the limit because of variability in the data (Baldwin 1996a).

${ }^{3}$ All decision criteria thresholds for TOC were based on the fuel value of sodium acetate.

This 95 percent confidence interval upper limit was obtained from subsegment $A$ of core 123, segment 9.

${ }^{5}$ This weight percent water result was the lowest sample mean measured, and was obtained from the upper half of core 123 , segment 3 .

${ }^{6}$ Although the actual decision criteria threshold listed in the DQO was $1 \mathrm{~g} / \mathrm{L}$, total alpha activity was reported in $\mu \mathrm{Ci} / \mathrm{g}$ rather than $\mathrm{g} / \mathrm{L}$. To convert the notification limit for total alpha into the same units as those used by the laboratory, it was assumed that all alpha decay originated from ${ }^{209} \mathrm{Pu}$. The SAP assumed a tank density of $1.5 \mathrm{~g} / \mathrm{mL}$, and using the specific activity of ${ }^{20} \mathrm{Pu}(0.0615 \mathrm{Ci} / \mathrm{g})$, the decision criteria threshold was converted to $41 \mu \mathrm{Ci} / \mathrm{g}$ using the equation below (Baldwin 1996b). This equation was also used to establish specific decision thresholds for each sample mean with a density greater than $1.5 \mathrm{~g} / \mathrm{mL}$, as directed by the SAP. The sample with the highest density, $1.97 \mathrm{~g} / \mathrm{mL}$, was quarter segment $C$ from core 123, segment 9 . This density was converted to a decision threshold of $31.2 \mu \mathrm{Ci} / \mathrm{g}$, representing the lowest threshold for any of the sludge samples. The conversion is presented below.

$$
\left[\frac{1 \mathrm{~g}}{L}\right]\left[\frac{1 \mathrm{~L}}{10^{3} \mathrm{~mL}}\right)\left(\frac{1}{\text { densiry }} \frac{\mathrm{mL}}{\mathrm{g}}\right]\left[\frac{0.0615 \mathrm{Ci}}{1 \mathrm{~g}}\right)\left(\frac{10^{6} \mu \mathrm{Ci}}{1 \mathrm{Ci}}\right)=\frac{61.5}{\text { density }} \frac{\mu \mathrm{Ci}}{\mathrm{g}} \text {. }
$$

This 95 percent confidence interval upper limit was obtained from core 128 , segment 1 .

The following DSC results are all given on a dry weight basis. Both the safety screening and organic complexant safety DQOs have established a decision criteria threshold of $480 \mathrm{~J} / \mathrm{g}$ for the DSC analyses, while the organic safety test plan established a decision threshold of $1,200 \mathrm{~J} / \mathrm{g}$. Exothermic reactions were noted in several of the samples, but they were all below the DQO thresholds (see Table 4-3). The single highest exothermic reaction showed a change in enthalpy of $301.9 \mathrm{~J} / \mathrm{g}$. One of the upper limits to a one-sided $95 \%$ confidence limit on the mean was greater than the decision threshold $(493.4 \mathrm{~J} / \mathrm{g}$ ), but this was attributed to variability in the data (Baldwin 1996a). 
The following TOC results are all given on a dry weight basis. The organic complexant safety DQO established the decision criteria threshold for TOC at $30,000 \mu \mathrm{g} \mathrm{C} / \mathrm{g}$, whereas the decision threshold for the organic safety test plan was $45,000 \mu \mathrm{g} \mathrm{C} / \mathrm{g}$. The mean TOC concentration was $4,720 \mu \mathrm{g} \mathrm{C} / \mathrm{g}$, the largest sample mean result was $15,400 \mu \mathrm{g} \mathrm{C} / \mathrm{g}$, and the highest upper limit to a one-sided 95 percent confidence interval on the mean for a single primary-duplicate pair was $18,600 \mu \mathrm{g} \mathrm{C} / \mathrm{g}$. All analytical results were thus far below the decision thresholds.

To investigate the relationship between DSC and the TOC content, the DSC dry weight results for those subsegments that had exothermic reactions are compared with the corresponding dry weight TOC results and the TOC energy equivalents in Table 5-4. This comparison may be biased since DSC reports net enthalpy change; if endotherms are present, they could mask the full extent of the actual exothermic reactions. The TOC data were converted to their energy equivalent using the following equation (Baldwin 1996b). The $632 \mathrm{~J} / \mathrm{g}$ value represents the energy equivalent of 5 weight percent TOC, based on a sodium acetate average energetics standard. Assuming that all of the TOC is present as sodium acetate may also bias this comparison.

$$
\text { Energy Equivalent }=w t \% \text { TOC }(\text { dry weight }) \frac{(632 \mathrm{~J} / \mathrm{g})}{5}
$$

Several of the sample means for weight percent water were below the organic complexant safety DQO decision threshold of 17 weight percent, the lowest sample mean being 6.38 weight percent. However, secondary analyses are only required if both the fuel and moisture decision limits are violated for a given subsegment. Because none of the DSC results showed exothermic reactions with a change in enthalpy greater than the decision threshold of $480 \mathrm{~J} / \mathrm{g}$, the low weight percent water values were not a concern. The weight percent water decision threshold for the organic safety test plan was 0.022 [Fuel (in $\mathrm{J} / \mathrm{g}$ ) $-1,200$ ] weight percent, or 20 weight percent. Since all fuel values were far below the decision threshold of $1,200 \mathrm{~J} / \mathrm{g}$ (the minimum amount of fuel that the test plan considers necessary to support a propagating reaction), the moisture content of the tank was not a factor.

The potential for criticality can be assessed from the total alpha activity data. The safety screening DQO decision criteria threshold is $1 \mathrm{~g} / \mathrm{L}$. Since the laboratory reported total alpha activity in units of $\mu \mathrm{Ci} / \mathrm{g}$, the $1 \mathrm{~g} / \mathrm{L}$ threshold was converted to $41 \mu \mathrm{Ci} / \mathrm{g}$, assuming a density of $1.5 \mathrm{~g} / \mathrm{mL}$ (Baldwin 1996b). If the analytical density for a particular sample mean exceeds $1.5 \mathrm{~g} / \mathrm{mL}$, then the threshold is adjusted according to the equation given in Table 5-3, Footnote 6 . Several of the sample densities were greater than $1.5 \mathrm{~g} / \mathrm{mL}$, the largest being $1.97 \mathrm{~g} / \mathrm{mL}$. This resulted in the lowest decision threshold being $31.2 \mu \mathrm{Ci} / \mathrm{g}$ for quarter segment $\mathrm{C}$ from core 123 , segment 9 . The overall tank mean was $0.0371 \mu \mathrm{Ci} / \mathrm{g}$, the highest sample mean was $0.150 \mu \mathrm{Ci} / \mathrm{g}$, and the highest upper limit to a one-sided 95 percent confidence interval on the mean was $0.156 \mu \mathrm{Ci} / \mathrm{g}$. Thus, all analytical and confidence interval results were well below their respective safety screening DQO decision criteria thresholds. 
Table 5-4. Comparison of DSC Analytical Results With TOC Energy Equivalents (Dry Weight Basis).

\begin{tabular}{|c|c|c|c|c|c|}
\hline Cores & & & 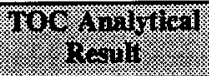 & $\begin{array}{l}\text { TEe Enerys' } \\
\text { grairalent }\end{array}$ & WSe ninition \\
\hline Sepment & Sinb-sezinent & Rin: & $15 \cdot 6$ & (1) 14 & (- \\
\hline \multirow[t]{3}{*}{$123: 6$} & \multirow[t]{3}{*}{ Lower $1 / 2$} & 1 & 6,000 & 75.8 & 101 \\
\hline & & 2 & 6,190 & 78.2 & 130.1 \\
\hline & & 3 & $-\cdots^{2}$ & $--^{2}$ & 77.8 \\
\hline \multirow[t]{2}{*}{$123: 9$} & \multirow[t]{2}{*}{$A$, top $1 / 4$} & 1 & 15,900 & 201 & 30.5 \\
\hline & & 2 & 14,800 & 187 & 57.3 \\
\hline \multirow[t]{2}{*}{$124: 5$} & \multirow[t]{2}{*}{ Lower $1 / 2$} & 1 & 5,850 & 73.9 & 273.6 \\
\hline & & 2 & 5,790 & 73.2 & 301.9 \\
\hline \multirow[t]{2}{*}{$124: 6$} & \multirow[t]{2}{*}{ Upper $1 / 2$} & 1 & 8,290 & 105 & 252.7 \\
\hline & & 2 & 7,630 & 96.4 & 270 \\
\hline \multirow[t]{2}{*}{$124: 6$} & \multirow[t]{2}{*}{ Lower $1 / 2$} & 1 & 9,480 & 120 & 141.1 \\
\hline & & 2 & 9,790 & 124 & 151.7 \\
\hline \multirow[t]{3}{*}{$128: 1$} & \multirow[t]{3}{*}{ Whole } & 1 & 7,220 & 91.3 & 0 \\
\hline & & 2 & $\overline{6,960}$ & 88.0 & 21.2 \\
\hline & & 3 & $--^{2}$ & $--^{2}$ & 30.8 \\
\hline \multirow[t]{2}{*}{$128: 4$} & \multirow[t]{2}{*}{ Lower $1 / 2$} & 1 & 12,800 & 162 & 267.6 \\
\hline & & 2 & 11,100 & 140 & 182.6 \\
\hline \multirow[t]{2}{*}{$128: 5$} & \multirow[t]{2}{*}{ Whole } & 1 & 5,900 & 74.6 & 13.70 \\
\hline & & 2 & 6,160 & 77.9 & 21.24 \\
\hline \multirow[t]{2}{*}{$128: 6$} & \multirow[t]{2}{*}{ Lower $1 / 2$} & 1 & 8,070 & 102 & 111.4 \\
\hline & & 2 & 7,710 & 97.5 & 116.1 \\
\hline \multirow[t]{2}{*}{$128: 7$} & \multirow[t]{2}{*}{ Lower $1 / 2$} & 1 & 9,660 & 122 & 131.1 \\
\hline & & 2 & 9,740 & 123 & 134.4 \\
\hline \multirow[t]{3}{*}{$128: 8$} & \multirow[t]{3}{*}{ Lower $1 / 2$} & 1 & 6,990 & 88.4 & 0 \\
\hline & & 2 & 7,420 & 93.8 & 112.2 \\
\hline & & 3 & $--^{2}$ & $--^{2}$ & 70.3 \\
\hline
\end{tabular}

Notes:

${ }^{1}$ The negative sign indicating an enthalpy change involving an exothermic reaction was not included because total energy in $\mathrm{J} / \mathrm{g}$ is being compared between the DSC and TOC results.

${ }^{2}$ Triplicate runs were not conducted on any of the TOC samples. 
The flammability of the gas in the tank headspace is an additional safety screening DQO consideration. The requirement is that any flammable gas present must be below 25 percent of the LFL. The analytical results showed a maximum of 5 percent of the LFL.

Another factor in assessing tank safety is the heat generation from radioactive decay and the resultant temperature increase of the waste. The 1995/1996 analytical results provided mean estimates for ${ }^{137} \mathrm{Cs}$ and ${ }^{89 / 90} \mathrm{Sr}$. Table 5-5 predicts the tank heat load to be $1,880 \mathrm{~W}$ $(6,420 \mathrm{Btu} / \mathrm{hr})$. The HTCE provided an estimate of $4,120 \mathrm{~W}(14,100 \mathrm{Btu} / \mathrm{hr})$, and Kummerer (1994) estimated $1,720 \mathrm{~W}(5,865 \mathrm{Btu} / \mathrm{hr})$ based on tank headspace temperatures. All of these estimates were well below the $11,700 \mathrm{~W}(40,000 \mathrm{Btu} / \mathrm{hr})$ design specification for single-shell tanks (Bergmann 1991). Since an upper temperature limit has been exhibited (Section 2.4.3), it may be concluded that any heat generated from radioactive sources throughout the year is dissipated.

Table 5-5. Tank 241-U-109 Estimated Heat Load. ${ }^{1}$

\begin{tabular}{|c|c|c|c|}
\hline Rarioninelide & 13010 & (1) & 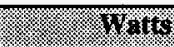 \\
\hline${ }^{137} \mathrm{Cs}$ & 122 & 3.57E+05 & 1,690 \\
\hline${ }^{89 / 90} \mathrm{Sr}$ & 9.70 & 28,400 & 190 \\
\hline Total & & $3.85 \mathrm{E}+05$ & 1,880 \\
\hline
\end{tabular}

Note:

'Because the composite level mean was higher than the segment level mean for both analytes, the composite analytical results were used in order to provide the most conservative estimate.

\subsubsection{Historical Model Evaluation}

The primary objective of the historical model evaluation DQO is to acquire adequate information through selective tank sampling to quantify the errors associated with predicting tank waste composition based on waste transaction history and waste type compositions (Simpson and McCain 1995).

The DQO identifies key waste components or key analytes for certain waste types, including SMMS2 saltslurry and SMMS1 saltcake. Tank 241-U-109 was selected for historical evaluation because it was expected to contain layers thick enough to provide entire segments composed of these two waste types (Agnew et al. 1996a). The first step in the evaluation is to compare the analytical results with DQO-defined concentration levels for the key analytes. This comparison indicates that the predicted waste type is in the tank and at the predicted location within the waste. If the analytical results are $\geq 10$ percent of the DQO levels (ratio of 0.1 or more), the waste type and layer identification are considered acceptable, and further analyses are requested (Simpson and McCain 1995). 
According to the TLM (Figure 2-3), segments 1 through 4 should be SMMS2 saltslurry and segments 5 through 8 should consist of SMMS1 saltcake. Segment 9 was predicted to be CWR1 and MW. The analytical results for the key analytes were compared to the historical model evaluation DQO-predicted concentrations for the SMMS2 saltslurry and SMMS1 saltcake waste types. The key analytes for these two waste types were sodium, aluminum, chromium (SMMS2 saltslurry only), carbonate, nitrate, and weight percent water. The comparisons were made on the segment level for all three cores, and the results indicate that all of the analytical results for the key analytes exceeded the 10 percent criterion specified in the $\mathrm{DQO}$, with the exception of the carbonate data from core 123 , segments 2,3 (upper 1/2), and 3 (lower 1/2). In general, however, it appears that the predicted waste types are present in the tank. 


\subsection{CONCLUSIONS AND RECOMMENDATIONS}

The waste in tank 241-U-109 was core-sampled in December 1995 and January 1996, and analyzed in accordance with the safety screening, organic complexant safety, and historical model evaluation DQOs and the organic safety test plan. The safety issues evaluated included energetics to determine the fuel content, TOC to determine its contribution to the total fuel content, weight percent water, total alpha activity to assess criticality, and flammable gas concentration. The SAP (Baldwin 1996b) required the laboratory to perform ICP and IC analyses for lithium and bromide to determine whether any samples were contaminated by HHF. Also, the historical model evaluation DQO required analyses of several additional analytes that will be used in an attempt to quantify the errors involved in predicting tank waste composition. All samples were analyzed at the Westinghouse Hanford Company 222-S Analytical Chemistry Laboratory. Vapor samples were taken from the headspace of the tank on August 10,1995 and analyzed to characterize the vapors present in the tank headspace according to the vapor sampling DQO.

Regarding the safety evaluation, comparisons were made between the analytical results and the decision criteria thresholds listed in the safety screening and organic complexant safety DQOs and the organic safety test plan. All of the following DSC and TOC values are given on a dry weight basis. No exothermic reactions with a change in enthalpy above $301.9 \mathrm{~J} / \mathrm{g}$ were observed in any of the samples, as compared with the safety screening and organic complexant safety DQOs decision criteria threshold of $480 \mathrm{~J} / \mathrm{g}$, and the organic safety test plan decision threshold of $1,200 \mathrm{~J} / \mathrm{g}$. Although the upper limit of the one-sided 95 percent confidence interval on the mean was $493.4 \mathrm{~J} / \mathrm{g}$, this was attributed to variability in the data (Baldwin 1996a).

The overall mean TOC result was $4,720 \mu \mathrm{g} \mathrm{C} / \mathrm{g}$, the highest sample mean was $15,400 \mu \mathrm{g} \mathrm{C} / \mathrm{g}$, and the highest one-sided 95 percent confidence interval upper limit on the mean was $18,600 \mu \mathrm{g} \mathrm{C} / \mathrm{g}$. All results were below the decision thresholds of $30,000 \mu \mathrm{g} \mathrm{C} / \mathrm{g}$ from the organic complexant safety $\mathrm{DQO}$ and $45,000 \mu \mathrm{g} \mathrm{C} / \mathrm{g}$ from the organic safety test plan. The weight percent water results were not critical from a safety viewpoint because neither the organic complexant $\mathrm{DQO}$ nor the organic safety test plan required a minimum percentage of water in the absence of exothermic reactions above the decision thresholds. No separable organic layer was detected in any of the samples. The highest sample mean for total alpha activity was $0.150 \mu \mathrm{Ci} / \mathrm{g}$, the highest one-sided 95 percent confidence interval upper limit on the mean was $0.156 \mu \mathrm{Ci} / \mathrm{g}$, and the overall mean was $0.0371 \mu \mathrm{Ci} / \mathrm{g}$. All total alpha activity values were at least two orders of magnitude below their safety screening thresholds. Vapor analysis showed all samples to be well below limits and do not indicate a safety concern. 
The flammability of the gas in the tank headspace is an additional safety screening DQO consideration. The decision threshold is that any flammable gas present must be below 25 percent of the LFL. This measurement was especially important considering that tank 241-U-109 is on the Flammable Gas Watch List. The analytical results showed a maximum of 5 percent of the LFL.

Based on analytical results, the estimated tank heat load was $1,880 \mathrm{~W}(6,420 \mathrm{Btu} / \mathrm{hr})$. The HTCE estimate of the tank heat load was $4,120 \mathrm{~W}(14,100 \mathrm{Btu} / \mathrm{hr})$, while the estimate based on the headspace temperature was $1,720 \mathrm{~W}(5,865 \mathrm{Btu} / \mathrm{hr})$. All three estimates were below the $11,700 \mathrm{~W}(40,000 \mathrm{Btu} / \mathrm{hr}$ ) high-heat threshold (Bergmann 1991). Since the tank exhibits an upper temperature limit, it is concluded that any heat generated from radioactive sources throughout the year is dissipated.

According to the criteria established in the safety screening and organic complexant DQOs and the organic safety test plan, the tank is considered safe.

The historical model evaluation DQO attempts to verify the presence of particular waste types by comparing the predicted concentrations of certain analytes with the analytical results. The results of these comparisons indicated that the tank does contain the predicted waste types.

Hydrostatic head fluid marked with a lithium bromide tracer was used during core sampling operations, and contamination of over 50 percent occurred in segment 3 of core 124 . Thus, the drainable liquid results and the solids weight percent water results from this segment were not used in any evaluations concerning this tank. Some HHF intrusion was also noted in segment 5 of core 128 . Because this contamination was less than 50 percent, the weight percent water results were corrected for the intrusion and used in all data evaluations.

A number of observations can be made concerning this tank:

1. Although tank 241-U-109 is on the Flammable Gas Watch List, the flammable gas concentration in the headspace is well below the threshold and is not a cause for concern.

2. The metal waste heel has a level of uranium that exceeds the value predicted from the transfer history.

3. The aluminum in the waste is mostly soluble in water. This agrees with the process history. 


\subsection{REFERENCES}

Agnew, S. F., J. Boyer, R. A. Corbin, T. B. Duran, J. R. Fitzpatrick, K. A. Jurgensen, T. P. Ortiz, and B. L. Young, 1996a, Hanford Tank Chemical and Radionuclide Inventories: HDW Model Rev. 3, LA-UR-96-858, Rev. 0, Los Alamos National Laboratory, Los Alamos, New Mexico.

Agnew, S. F., P. Baca, R. A. Corbin, T. B. Duran, and K. A. Jurgensen, 1996b, Waste Status and Transaction Record Summary for the Southwest Quadrant, WHC-SD-WM-TI-614, Rev. 1, Westinghouse Hanford Company, Richland, Washington.

Alstad, A. T., 1993, Riser Configuration Document for Single-Shell Waste Tanks, WHC-SD-RE-TI-053, Rev. 9, Westinghouse Hanford Company, Richland, Washington.

Baldwin, J. H., 1996a, Final Report for Tank 241-U-109, Rotary and Push-Mode Cores 123, 124, and 128, WHC-SD-WM-DP-181, Rev. 1, Westinghouse Hanford Company, Richland, Washington.

Baldwin, J. H., 1996b, Tank 241-U-109 Push Core Sampling and Analysis Plan, WHC-SD-WM-TSAP-052, Rev. 1-A, Westinghouse Hanford Company, Richland, Washington.

Bergmann, L. M., 1991, Single-Shell Tank Isolation Safety Analysis Report, WHC-SD-WM-SAR-006, Rev. 2, Westinghouse Hanford Company, Richland, Washington.

Brevick, C. H., L. A. Gaddis, and E. D. Johnson, 1994, Supporting Document for the Historical Tank Content Estimate for U Tank Farm, WHC-SD-WM-ER-325, Rev. 0, Westinghouse Hanford Company, Richland, Washington.

Brown, R. G., 1996, Compilation of Hydrogen Data for 22 Single-Shell Flammable Gas Watch List Tanks, WHC-SD-WM-ER-576, Rev. 0, Westinghouse Hanford Company, Richland, Washington.

DeLorenzo, D. S., A. T. DiCenso, D. B. Hiller, K. W. Johnson, J. H. Rutherford, D. J. Smith, and B. C. Simpson, 1994, Tank Characterization Reference Guide, WHC-SD-WM-TI-648, Rev. 0, Westinghouse Hanford Company, Richland, Washington.

DOE, 1995, Hanford Analytical Services Quality Assurance Plan, DOE/RL-94-95, Rev. 2, U.S. Department of Energy, Richland, Washington. 
Dukelow, G. T., J. W. Hunt, H. Babad, and J. E. Meacham, 1995, Tank Safety Screening Data Quality Objective, WHC-SD-WM-SP-004, Rev. 2, Westinghouse Hanford Company, Richland, Washington.

Evans, J. C., B. L. Thomas, K. H. Pool, K. B. Olsen, J. S. Fruchter, and K. L. Silves, 1996, Headspace Vapor Characterization of Hanford Waste Tank 24I-U-109: Results from Samples Collected on 8/10/95, PNNL-10959, UC-606, Pacific Northwest National Laboratory, Richland, Washington.

Ecology, EPA, and DOE, 1996, Hanford Federal Facility Agreement and Consent Order, as amended, Washington State Department of Ecology, U.S. Environmental Protection Agency, and U.S. Department of Energy, Olympia, Washington.

Hanlon, B. M., 1996, Waste Tank Summary Report for Month Ending March 31, 1996, WHC-EP-0182-96, Westinghouse Hanford Company, Richland, Washington.

Horton, J.E. to W.R. Christensen, December 15, 1975a, Analysis and Characterization of Sludge From Tank 109-U, ARHCO internal letter, Atlantic Richfield Hanford Company, Richland, Washington.

Horton, J.E. to W.R. Christensen, December, 1975b, Concentration Laboratory Assistance, ARHCO internal report, Budget Number B0651, Atlantic Richfield Hanford Company, Richland, Washington

Kummerer, M., 1994, Topical Report on Heat Removal Characteristics of Waste Storage Tanks, WHC-SD-WM-SARR-010, Rev. 0, Westinghouse Hanford Company, Richland, Washington.

Kupfer, M. J., J. M. Conner, R. A. Kirkbride, and J. R. Mobley, 1994, Interim Data Quality Objectives for Waste Pretreatment and Vitrification, WHC-SD-WM-DQO-001, Rev. 1, Westinghouse Hanford Company, Richland, Washington.

Leach, C. E., and S. M. Stahl, 1993, Hanford Site Tank Farm Facilities Interim Safety Basis, WHC-SD-WM-ISB-001, Rev .0, Westinghouse Hanford Company, Richland, Washington.

Lipnicki, J., 1995, Waste Tank Risers Available for Sampling, WHC-SD-WM-TI-710, Rev. 2, Westinghouse Hanford Company, Richland, Washington.

Meacham, J. E., 1995, Test Plan for Samples From Hanford Waste Tanks 241-BY-103, $B Y-104, B Y-105, B Y-106, B Y-108, B Y-110, T Y-103, U-105, U-107, U-108$, and $U-109$, WHC-SD-WM-TP-378, Rev. 0, Westinghouse Hanford Company, Richland, Washington. 
Osborne, J. W., J. L. Huckaby, E. R. Hewitt, C. M. Anderson, D. D. Mahlum, G. A. Publisher, J. Y. Young, 1995, Data Quality Objectives for Generic In-Tank Health and Safety Vapors Resolution, WHC-SD-WM-DQO-002, Rev. 1, Westinghouse Hanford Company, Richland, Washington.

Rogers, R. D., and H. T. Daniels, 1944, Specifications for Construction of Composite Storage Tanks Bldg. \#241 at Hanford Engineer Works, CVI-73550, E. I. Du Pont de Nemours \& Co., Richland, Washington.

Simpson, B. C., and D. J. McCain, 1995, Historical Model Evaluation Data Requirements, WHC-SD-WM-DQO-018, Rev. 0A, Westinghouse Hanford Company, Richland, Washington.

Tran, T. T., 1993, Thermocouple Status Single-Shell and Double-Shell Waste Tanks, WHC-SD-WM-TI-553, Rev. 0, Westinghouse Hanford Company, Richland, Washington.

Turner, D. A., H. Babad, L. L. Buckley, and J. E. Meacham, 1995, Data Quality Objective to Support Resolution of the Organic Complexant Safety Issue, WHC-SD-WM-DQO-006, Rev. 2, Westinghouse Hanford Company, Richland, Washington.

Vitro Engineering Corporation, 1988, Piping Waste Tank Isolation TK 241-U-109, Drawing H-2-73157, Rev. 4, ICF Kaiser Hanford, Richland, Washington.

WHC, 1996, Surveillance Analysis Computer System database, June 24, 1996, Tank Farm Surveillance Engineering, Westinghouse Hanford Company, Richland, Washington.

Winkelman, W. D., 1996, Technical Basis and Spreadsheet Documentation for Correcting Waste Tank Core Samples for Water Intrusion Based on LiBr Tracers, WHC-SD-WM-CSWD-081, Rev. 0, Westinghouse Hanford Company, Richland, Washington. 
WHC-SD-WM-ER-609 Rev. 0

This page intentionally left blank. 
WHC-SD-WM-ER-609 Rev. 0

APPENDIX A

ANALYTICAL RESULTS FROM 1995/1996 CORE SAMPLING OF SINGLE-SHELL TANK 241-U-109 
WHC-SD-WM-ER-609 Rev. 0

This page intentionally left blank. 


\section{A.0 ANALYTICAL RESULTS FROM 1995/1996 CORE SAMPLING OF SINGLE-SHELL TANK 241-C-109}

\section{A.1 INTRODUCTION}

Appendix A reports the chemical, radiochemical, and physical characteristics of tank 241-U-109 in table form and in terms of the specific concentrations of metals, ions, radionuclides, and physical properties.

Each data table lists the following: laboratory sample identification, sample origin (core/segment/subsegment, or composite), an original and duplicate result for each sample, a sample mean, a mean for the tank in which all three core means are weighted equally, an RSD (mean), and a projected tank inventory for the particular analyte using the weighted mean, the waste volume, the density, and the appropriate conversion factors. The projected tank inventory column is not applicable to the weight percent water, DSC, or density data. The data are listed in standard notation for values greater than 0.001 and less than 100,000. Values outside these limits are listed in scientific notation.

The tables are numbered A-1 through A-27. A description of the units and symbols used in the analyte tables and the references used in compiling the analytical data (Baldwin 1996a) are found in the List of Terms and Section 7.0, respectively. For a description of the sampling event and information on sampling rationale and locations, see Section 3.0.

\section{A.2 ANALYTE TABLE DESCRIPTION}

The "Sample Number" column lists the laboratory sample for which the analyte was measured.

Column two specifies the core and segment from which each sample was derived.

Column three specifies the subsegment or whole segment for which the analyte was measured. If adequate sample was available, the waste from a given segment was split into upper and lower halves, or divided into subsegments (A, B, and C). If inadequate material was recovered to split the segment, it was analyzed as a "whole" segment. The single drainable liquid result is identified as " $\mathrm{DL}$ ".

The "Result" and "Duplicate" columns are self-explanatory. The "Sample Mean" column is the average of the result and duplicate values. If the result and duplicate values were both nondetected or detected, then the mean is expressed as a nondetected or detected value, respectively. If one of the two values is nondetected and one is detected, the sample mean is expressed as a detected result. The result and duplicate values, as well as the result/duplicate 
means, are reported in the tables exactly as found in the original laboratory data package. The means may appear to have been rounded up in some cases and rounded down in others. This is because the analytical results given in the tables may have fewer significant figures than originally reported, not because the means were incorrectly calculated.

The overall (or analyte concentration) means for the waste in tank 241-U-109 are given in column seven, and were calculated as follows.

To obtain the overall weighted mean for the solids portion of the tank contents based on the segment level results, the individual sample result and duplicate pairs within a given subsegment were first averaged to obtain a sample mean. The DSC, TGA, TIC and TOC analyses each had several triplicate runs conducted, and they were averaged into the calculation of the particular subsegment means. The subsegment means within a given segment were then averaged to obtain a segment mean, the segment means within a given core were averaged to obtain a core mean, and finally the three core means were averaged to obtain the overall mean. Not all of these steps were necessary for each analyte or for each subsegment, but the procedure to be followed is the same.

All values, including those below the detection level (indicated by the less-than symbol, <), were used in calculating the overall means. If 50 percent or more of all the individual sample and duplicate results were detected, then the overall mean was expressed as a detected value. If greater than 50 percent of all the individual results were nondetected, then the overall mean was expressed as a nondetected value. The implication associated with nondetected numbers as quantitative observations results in the mean concentrations and inventory estimates being biased. The magnitude of the bias is unknown and the results should be used with caution.

Separate overall means were also calculated for the segment level acid-digestion analyses and the various composite samples following the same detected/nondetected rules specified above. The overall means for segment level acid-digested analytes were weighted in the same manner as the segment level analyses specified above. The overall means for the acid and fusion-digestion composite samples were a simple average of the three core means. As discussed in Section 4-4, drainable liquid means, RSDs, and inventories were not calculated due to HHF contamination, but the analytical results are included in the following tables for information.

The RSD (mean), given in column eight, was computed for applicable analytes using standard ANOVA statistical techniques (nested models). If the overall mean for a given analyte was "detected", then an RSD (mean) was also calculated for that analyte. Because all "detected" means also had all of the individual sample/duplicate results detected, there are no unknown biases in the statistical calculations for tank 241-U-109. 
As discussed in Section 4.1.4, HHF contamination precluded the use of the weight percent water data from core 124 , segment 3 . The results are reported in Table A-25 for information only, and were not used in the overall mean estimates or any other evaluations. The solids data for this subsegment were retained, as a close examination of the data did not reveal any obvious discrepancies with the analytical results from neighboring segments. A low level of HHF contamination occurred in segment 5 of Core 128. The weight percent water results were corrected for the contamination, and the corrected values were used in the overall mean estimate and other evaluations. See Section 4.1 .4 for a more complete discussion.

The projected inventory, given in column nine, is the product of the overall analyte concentration mean, the volume of tank waste $(1,753 \mathrm{~kL}$ [463 kgal]), the density $(1.67 \mathrm{~g} / \mathrm{mL})$, and the appropriate conversion factors. Because the only DL recovered was most likely HHF, it was decided to use the entire tank inventory estimate of 1,753 kL (463 $\mathrm{kgal}$ ) in calculating the solids inventory.

The four quality control parameters assessed on the tank 241-U-109 samples were standard recoveries, spike recoveries, duplicate analyses (RPDs), and blanks. These were summarized in Section 5.1.2. More specific information is provided in the following tables. Sample and duplicate pairs in which any of the QC parameters were outside their specified limits are superscripted in column 6 as follows:

QC:a -- indicates that the standard recovery was below the QC range.

$\mathrm{QC}: \mathrm{b}$ - indicates that the standard recovery was above the QC range.

QC:c -- indicates that the spike recovery was below the QC range.

$\mathrm{QC}: \mathrm{d}$-- indicates that the spike recovery was above the QC range.

QC:e -- indicates that the RPD was greater than the QC limit range.

QC:f -- indicates blank contamination. 
WHC-SD-WM-ER-609 Rev. 0

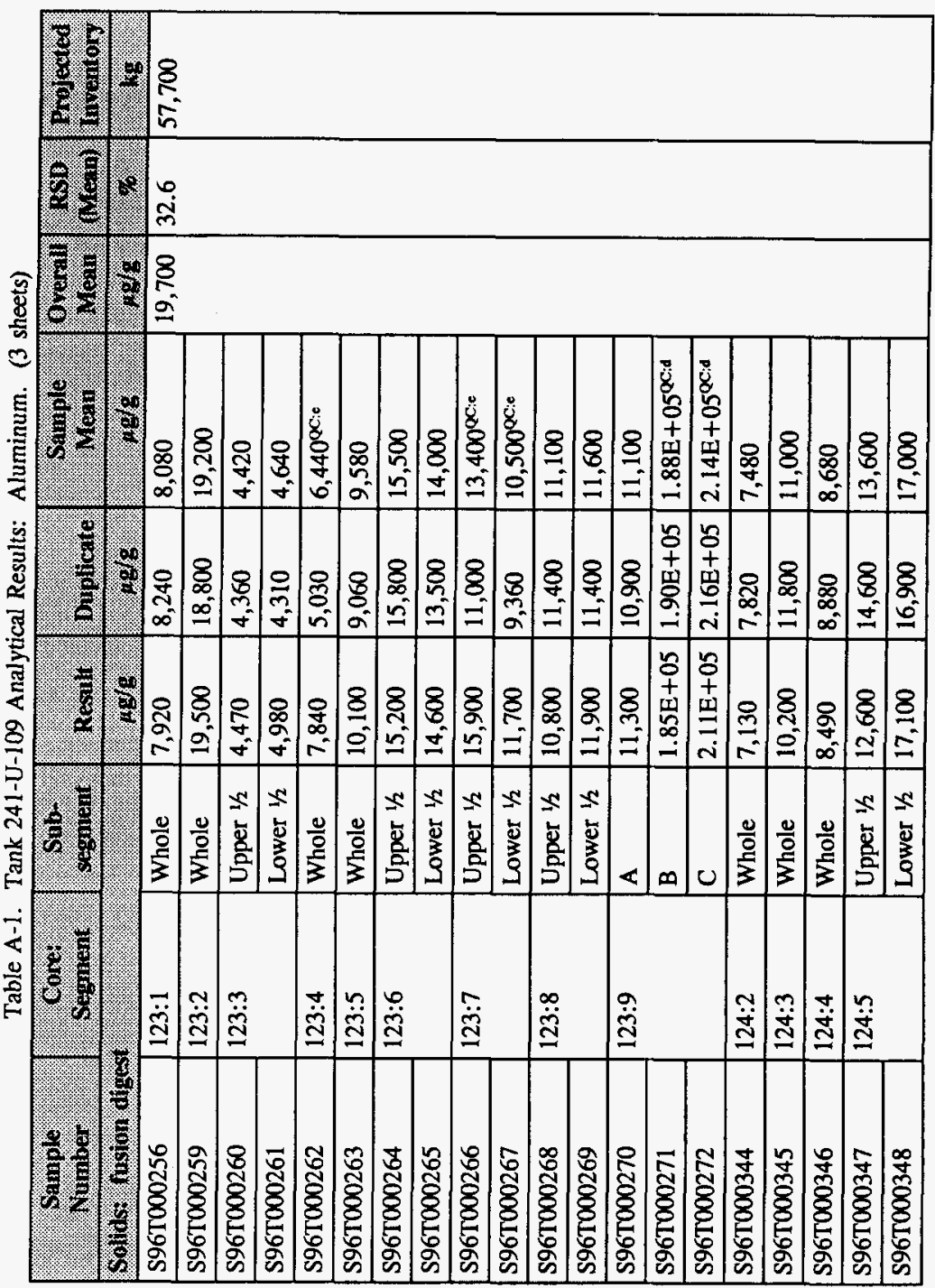




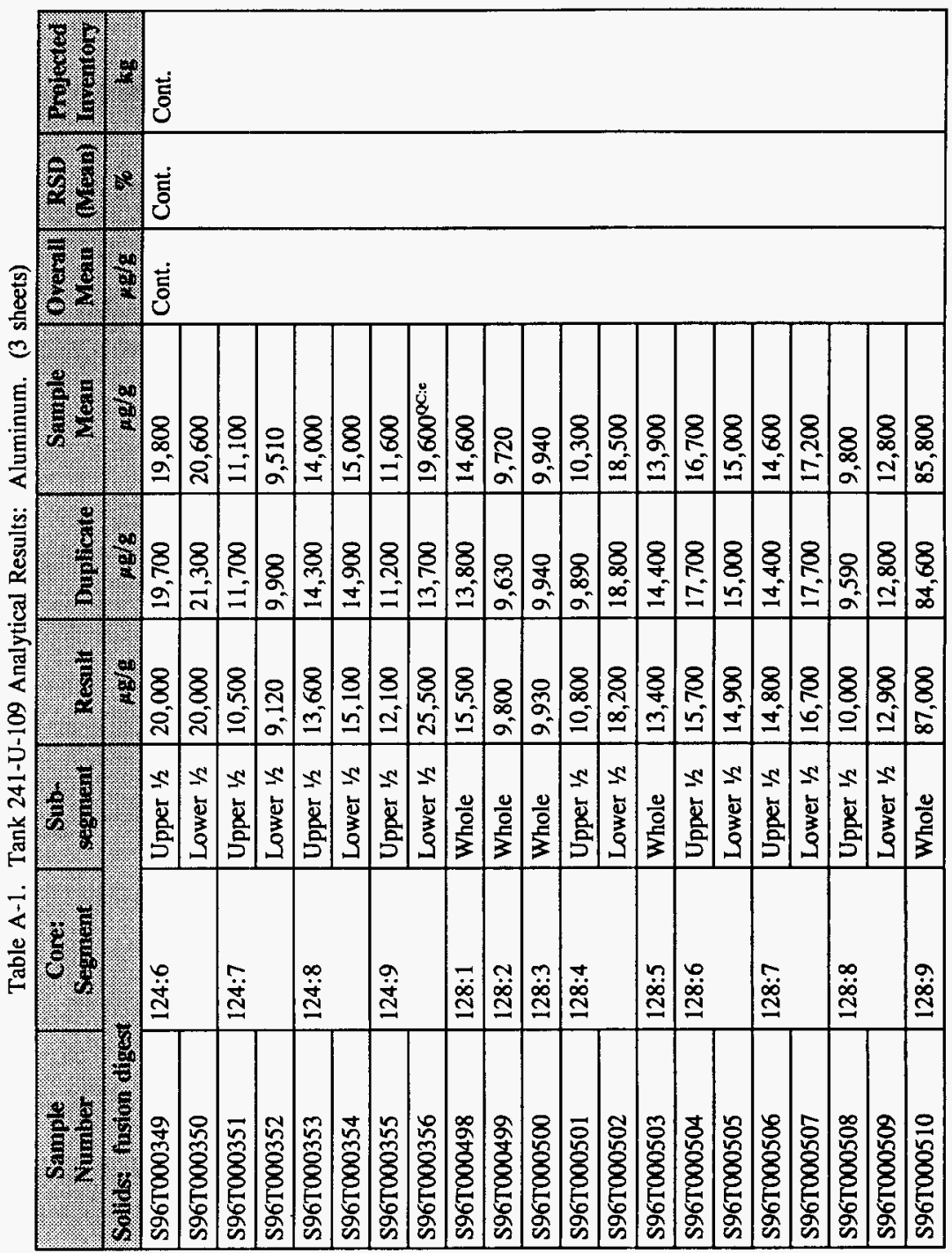


WHC-SD-WM-ER-609 Rev. 0

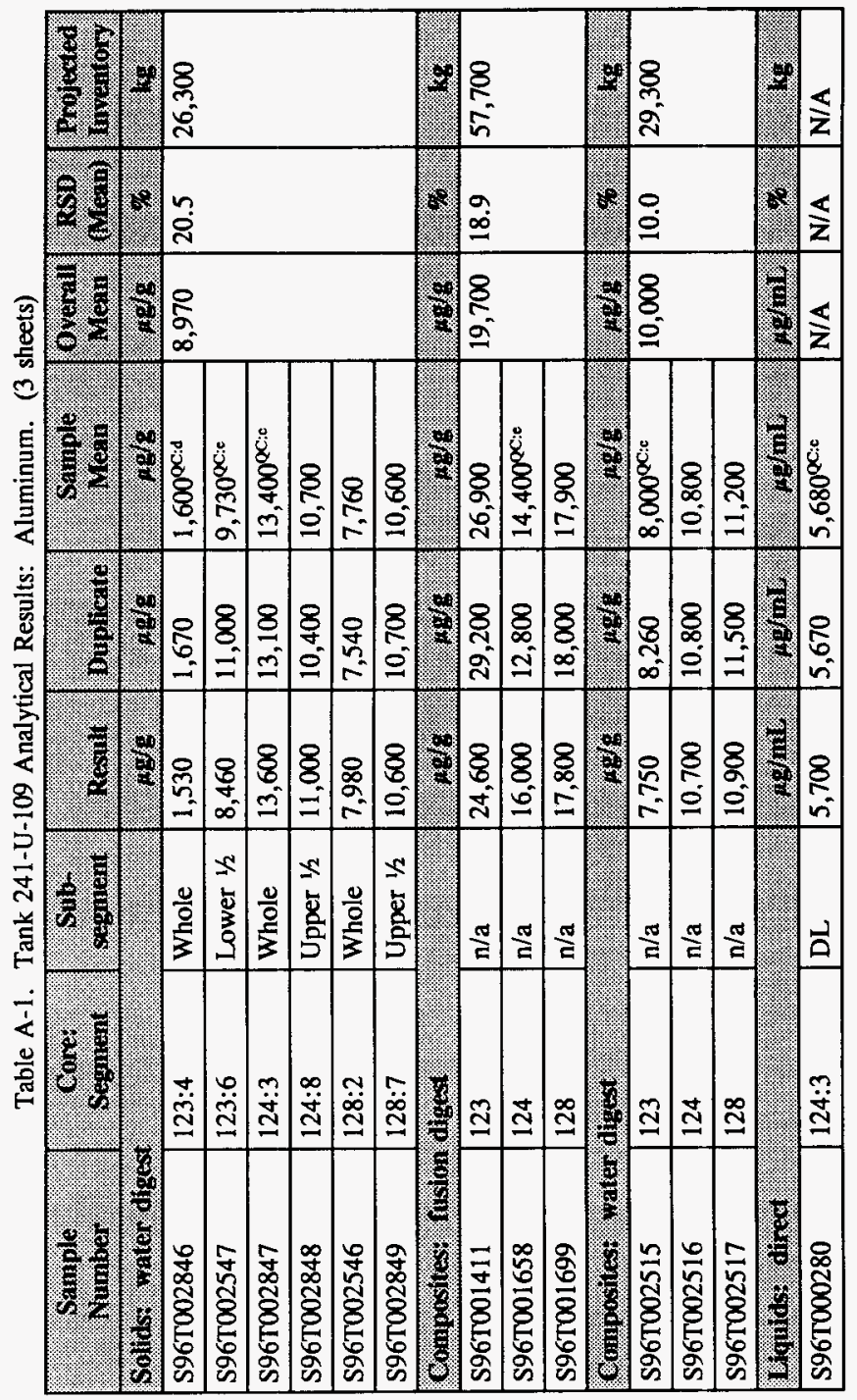


WHC-SD-WM-ER-609 Rev. 0

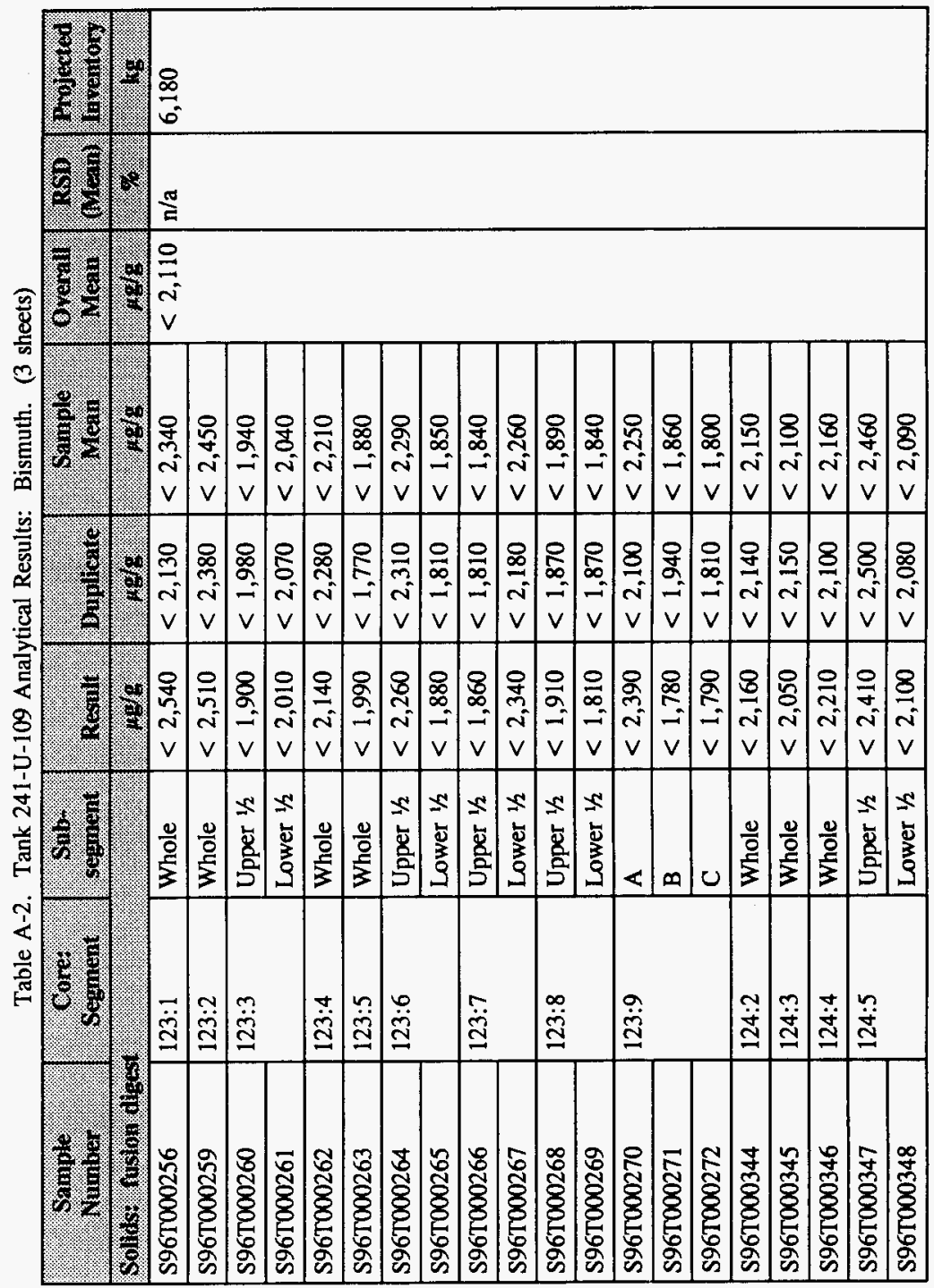


Table A-2. Tank 241-U-109 Analytical Results: Bismuth. (3 sheets)

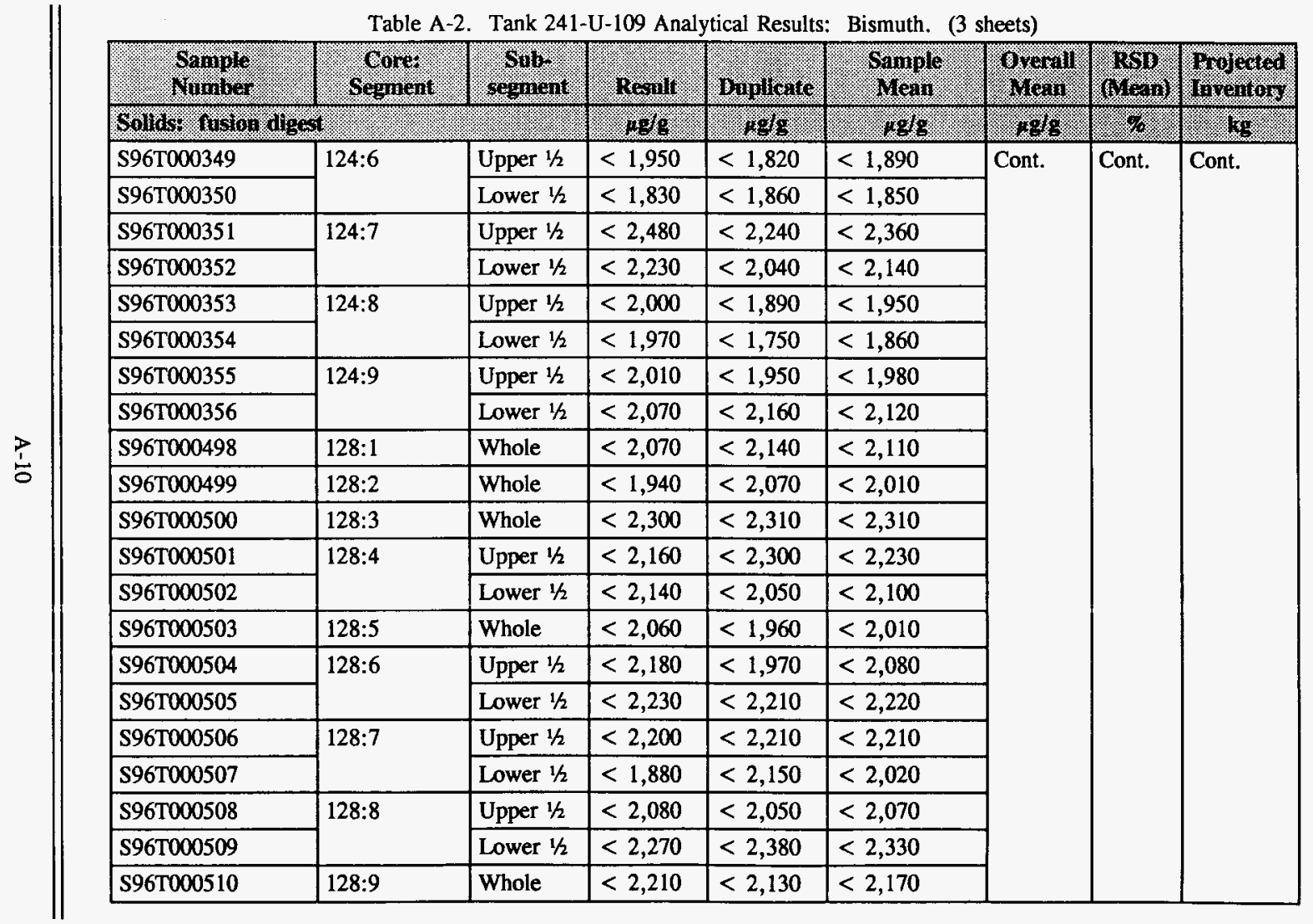




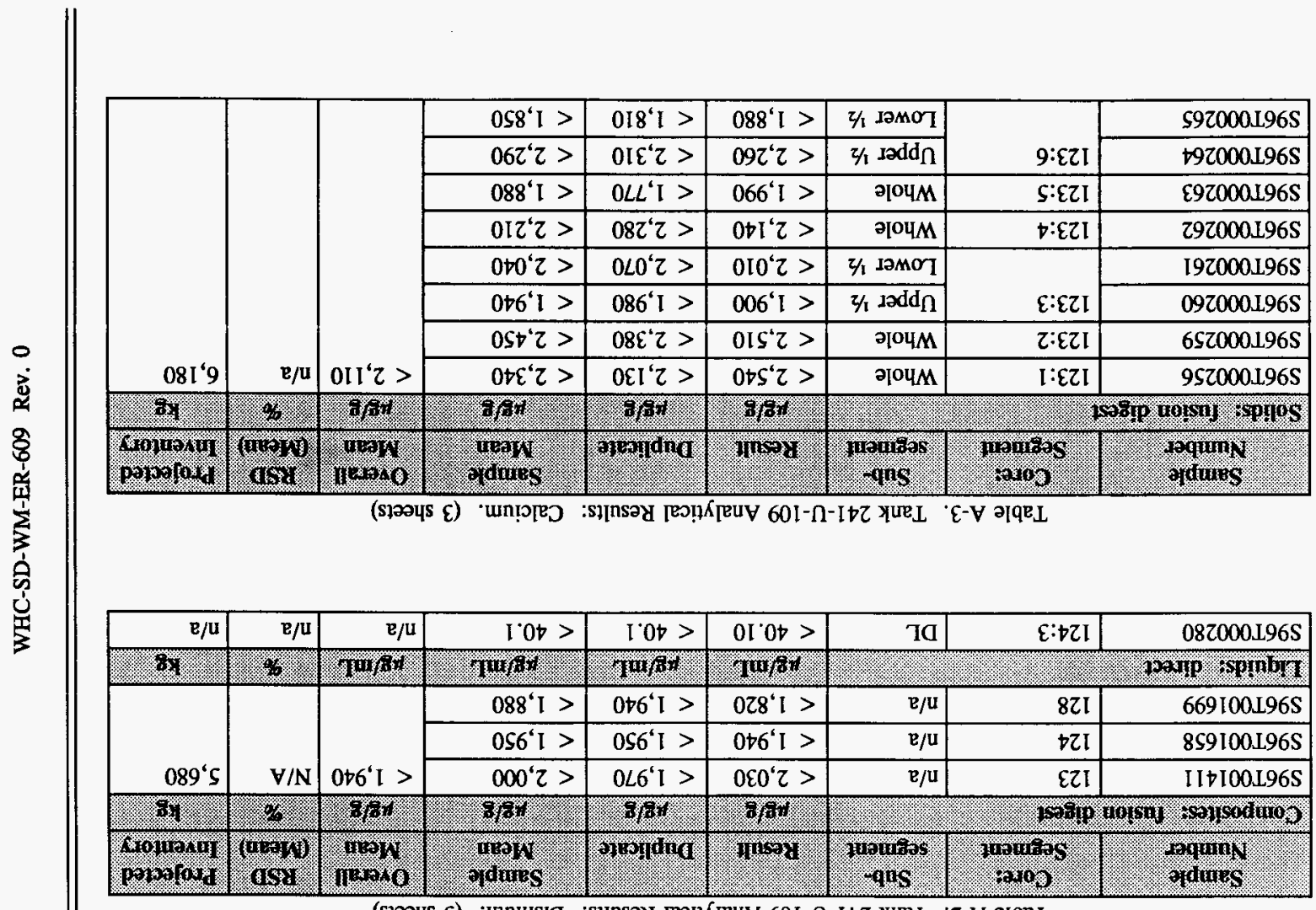

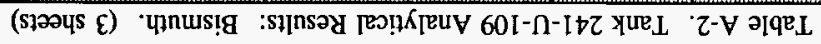




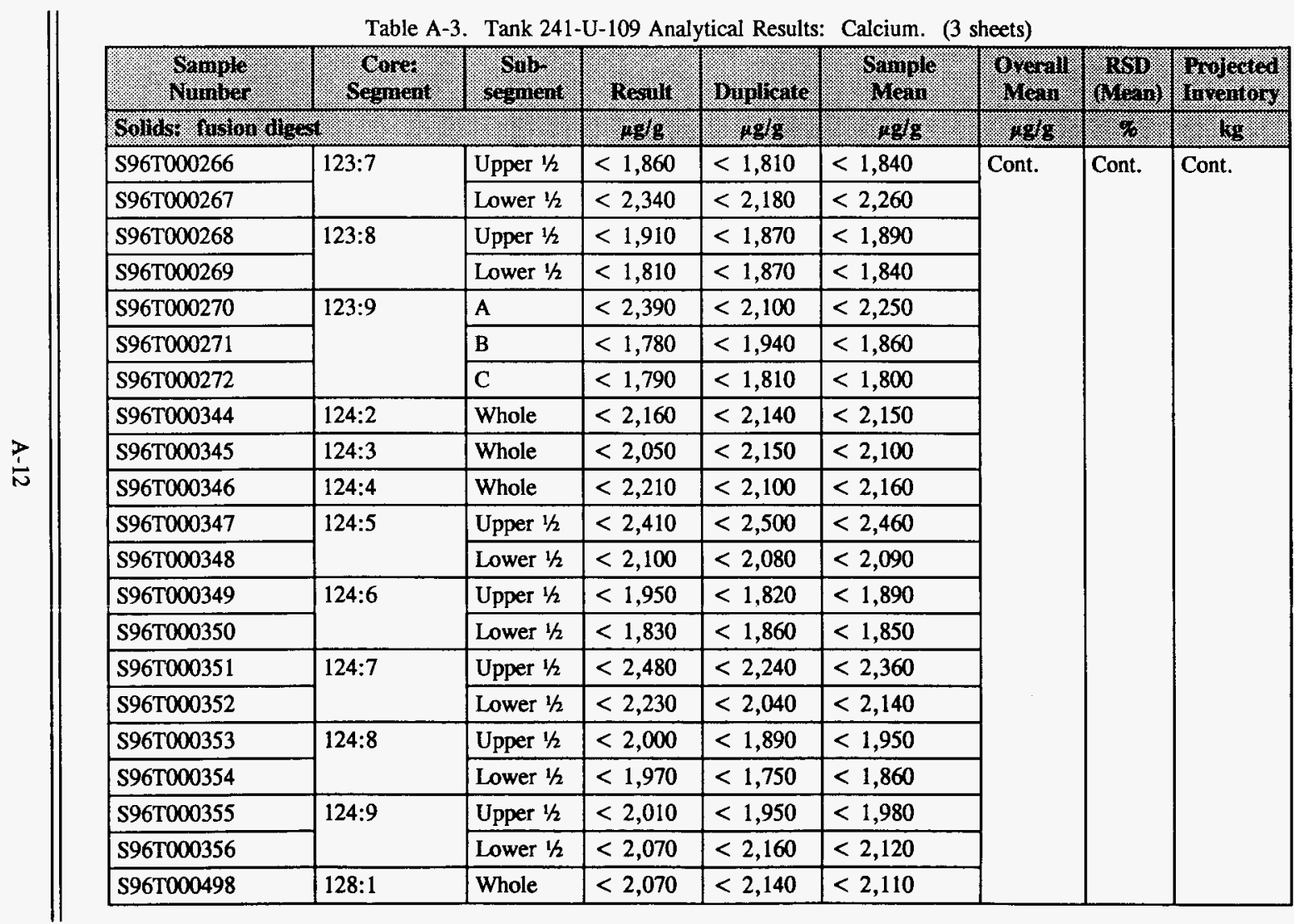


Table A-3. Tank 241-U-109 Analytical Results: Calcium. (3 sheets)

\begin{tabular}{|c|c|c|c|c|c|c|c|c|}
\hline $\begin{array}{l}\text { Sample } \\
\text { Number } \\
\text {. }\end{array}$ & $\begin{array}{l}\text { Core: } \\
\text { Segrent }\end{array}$ & $\begin{array}{l}\text { Sub } \\
\text { sepment: }\end{array}$ & Resall & Buplicate & $\begin{array}{l}\text { Sample } \\
\text { Mrean }\end{array}$ & $\begin{array}{l}\text { Orerall } \\
\text { Ineal }\end{array}$ & 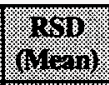 & $\begin{array}{l}\text { Projedted } \\
\text { Inventory }\end{array}$ \\
\hline \multicolumn{3}{|c|}{ Solids: rision digest } & $198 / 8$ & 19g/g. & . 1918 & 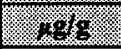 & 8 & 1.8. \\
\hline S96T000499 & $128: 2$ & Whole & $<1,940$ & $<2,070$ & $<2,010$ & \multirow[t]{12}{*}{ Cont. } & \multirow[t]{12}{*}{ Cont. } & \multirow[t]{12}{*}{ Cont. } \\
\hline S96T000500 & $128: 3$ & Whole & $<2,300$ & $<2,310$ & $<2,310$ & & & \\
\hline S96T000501 & \multirow[t]{2}{*}{$128: 4$} & Upper $1 / 2$ & $<2,160$ & $<2,300$ & $<2,230$ & & & \\
\hline S96T000502 & & Lower $1 / 2$ & $<2,140$ & $<2,050$ & $<2,100$ & & & \\
\hline S96T000503 & 128:5 & Whole & $<2,060$ & $<1,960$ & $<2,010$ & & & \\
\hline S96T000504 & \multirow[t]{2}{*}{$128: 6$} & Upper $1 / 2$ & $<2,180$ & $<1,970$ & $<2,080$ & & & \\
\hline S96T000505 & & Lower $1 / 2$ & $<2,230$ & $<2,210$ & $<2,220$ & & & \\
\hline S96T000506 & \multirow[t]{2}{*}{$128: 7$} & Upper $1 / 2$ & $<2,200$ & $<2,210$ & $<2,210$ & & & \\
\hline S96T000507 & & Lower $1 / 2$ & $<1,880$ & $<2,150$ & $<2,020$ & & & \\
\hline S96T000508 & \multirow[t]{2}{*}{ 128:8 } & Upper $1 / 2$ & $<2,080$ & $<2,050$ & $<2,070$ & & & \\
\hline S96T000509 & & Lower $1 / 2$ & $<2,270$ & $<2,380$ & $<2,330$ & & & \\
\hline S96T000510 & $128: 9$ & Whole & $<2,210$ & $<2,130$ & $<2,170$ & & & \\
\hline \multicolumn{3}{|c|}{ Conmpositest fision digest } & $\mu \mathrm{g} / \mathrm{g}$ & $4 \mathrm{~g} / \mathrm{g}$ & $48 \mathrm{~g}$ & $\mu \mathrm{g} / \mathrm{g}$ & 7 & leg \\
\hline S96T001411 & 123 & $n / a$ & $<2,030$ & $<1,970$ & $<2,000$ & \multirow[t]{3}{*}{$<1,940$} & \multirow[t]{3}{*}{$n / a$} & \multirow[t]{3}{*}{5,680} \\
\hline S96T001658 & 124 & $n / a$ & $<1,940$ & $<1,950$ & $<1,950$ & & & \\
\hline S96T001699 & 128 & $n / a$ & $<1,820$ & $<1,940$ & $<1,880$ & & & \\
\hline \multicolumn{3}{|c|}{ Wiguids dircer } & $48 / \mathrm{ni}$ & ig/nit & S 4 gin1 & egini & 8. & $\sqrt{188}$ \\
\hline S96T000280 & $124: 3$ & DL & $<40.10$ & $<40.1$ & $<40.1$ & $\mathrm{n} / \mathrm{a}$ & $\mathrm{n} / \mathrm{a}$ & $n / a$ \\
\hline
\end{tabular}


Table A-4. Tank 241-U-109 Analytical Results: Chromium. (3 sheets)

\begin{tabular}{|c|c|c|c|c|c|c|c|c|}
\hline Sample & Somer & Wol & \%. & Buplicate & Sample & 6romili: & 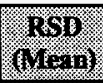 & 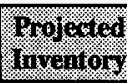 \\
\hline \multicolumn{2}{|c|}{ Sollds } & (2:-3: & 1096 & .989 & 498 & 818 & \% & 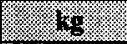 \\
\hline S96T000256 & $123: 1$ & Whole & 2,890 & 3,040 & 2,960 & \multirow{20}{*}{3,690} & \multirow[t]{20}{*}{14.1} & \multirow[t]{20}{*}{10,800} \\
\hline S96T000259 & $123: 2$ & Whole & 1,870 & 1,750 & 1,810 & & & \\
\hline S96T000260 & \multirow[t]{2}{*}{$123: 3$} & Upper $1 / 2$ & 1,330 & 1,360 & 1,340 & & & \\
\hline S96T000261 & & Lower $1 / 2$ & 1,570 & 1,390 & 1,480 & & & \\
\hline S96T000262 & $123: 4$ & Whole & 2,470 & 2,490 & 2,480 & & & \\
\hline S96T000263 & $123: 5$ & Whole & 3,410 & 2,510 & $2,960^{\mathrm{QC:e}}$ & & & \\
\hline S96T000264 & \multirow[t]{2}{*}{$123: 6$} & Upper $1 / 2$ & 3,820 & 3,920 & 3,870 & & & \\
\hline S96T000265 & & Lower $1 / 2$ & 3,460 & 3,530 & 3,500 & & & \\
\hline S96T000266 & \multirow[t]{2}{*}{$123: 7$} & Upper $1 / 2$ & 3,270 & 3,200 & 3,240 & & & \\
\hline S96T000267 & & Lower $1 / 2$ & 3,060 & 2,320 & $2,690^{\alpha c: e}$ & & & \\
\hline S96T000268 & \multirow[t]{2}{*}{$123: 8$} & Upper $1 / 2$ & 3,490 & 3,620 & 3,560 & & & \\
\hline$\$ 96 \mathrm{T000269}$ & & Lower $1 / 2$ & 3,130 & 3,310 & 3,220 & & & \\
\hline S96T000270 & \multirow[t]{3}{*}{$123: 9$} & A & 5,490 & 5,970 & 5,730 & & & \\
\hline S96T000271 & & B & 1,990 & 1,830 & 1,910 & & & \\
\hline S96T000272 & & $\mathrm{C}$ & 1,240 & 1,120 & 1,180 & & & \\
\hline S96T000344 & $124: 2$ & Whole & 2,640 & 3,730 & $3,180^{\alpha C: e}$ & & & \\
\hline S96T000345 & $124: 3$ & Whole & 3,190 & 3,360 & 3,280 & & & \\
\hline S96T000346 & $124: 4$ & Whole & 3,040 & 3,120 & 3,080 & & & \\
\hline S96T000347 & \multirow[t]{2}{*}{$124: 5$} & Upper $1 / 2$ & 4,240 & 5,510 & $4,880^{\alpha C: e}$ & & & \\
\hline S96T000348 & & Lower $1 / 2$ & 4,310 & 4,440 & 4,380 & & & \\
\hline
\end{tabular}


Table A-4. Tank 241-U-109 Analytical Results: Chromium. (3 sheets)

\begin{tabular}{|c|c|c|c|c|c|c|c|c|}
\hline $\begin{array}{l}\text { Sample } \\
\text { Vumper }\end{array}$ & gegrient & $\begin{array}{l}\text { Sub } \\
\text { cegnient }\end{array}$ & Resull & Diplicate & orinoplo & 6ronin & 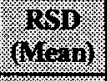 & Wroseorod \\
\hline \multicolumn{2}{|c|}{ 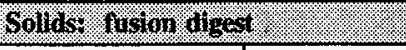 } & (2) & $6 y_{3}$ & 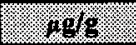 & $3 x_{5}$ & 48 & (6) & y. \\
\hline S96T000349 & \multirow[t]{2}{*}{$124: 6$} & Upper $1 / 2$ & 5,310 & 5,370 & 5,340 & \multirow[t]{21}{*}{ Cont. } & \multirow[t]{21}{*}{ Cont. } & \multirow[t]{21}{*}{ Cont. } \\
\hline S96T000350 & & Lower $1 / 2$ & 5,280 & 5,790 & 5,540 & & & \\
\hline S96T000351 & \multirow[t]{2}{*}{$124: 7$} & Upper $1 / 2$ & 3,150 & 3,220 & 3,180 & & & \\
\hline S96T000352 & & Lower $1 / 2$ & 2,350 & 2,510 & 2,430 & & & \\
\hline \$96T000353 & \multirow[t]{2}{*}{$124: 8$} & Upper $1 / 2$ & 4,020 & 4,180 & 4,100 & & & \\
\hline S96T000354 & & Lower $1 / 2$ & 4,940 & 4,930 & 4,940 & & & \\
\hline S96T000355 & \multirow[t]{2}{*}{$124: 9$} & Upper $1 / 2$ & 4,210 & 4,180 & 4,200 & & & \\
\hline S96T000356 & & Lower $1 / 2$ & 3,090 & 3,150 & 3,120 & & & \\
\hline S96T000498 & 128:1 & Whole & 8,790 & 7,710 & 8,250 & & & \\
\hline S96T000499 & $128: 2$ & Whole & 3,260 & 3,280 & 3,270 & & & \\
\hline S96T000500 & $128: 3$ & Whole & 2,660 & 2,710 & 2,680 & & & \\
\hline S96T000501 & \multirow[t]{2}{*}{$128: 4$} & Upper $1 / 2$ & 2,530 & 2,520 & 2,520 & & & \\
\hline S96T000502 & & Lower $1 / 2$ & 7,560 & 7,110 & 7,340 & & & \\
\hline S96T000503 & $128: 5$ & Whole & 4,280 & 4,560 & 4,420 & & & \\
\hline S96T000504 & \multirow[t]{2}{*}{$128: 6$} & Upper $1 / 2$ & 5,490 & 5,510 & 5,500 & & & \\
\hline S96T000505 & & Lower $1 / 2$ & 5,000 & 5,240 & 5,120 & & & \\
\hline S96T000506 & \multirow[t]{2}{*}{$128: 7$} & Upper $1 / 2$ & 5,350 & 4,850 & 5,100 & & & \\
\hline S96T000507 & & Lower $1 / 2$ & 5,780 & 5,520 & 5,650 & & & \\
\hline S96T000508 & \multirow[t]{2}{*}{$128: 8$} & Upper $1 / 2$ & 3,110 & 3,020 & 3,060 & & & \\
\hline \$96T000509 & & Lower $1 / 2$ & 3,850 & 3,750 & 3,800 & & & \\
\hline S96T000510 & 128:9 & Whole & 3,020 & 3,070 & 3,040 & & & \\
\hline
\end{tabular}


Table A-4. Tank 241-U-109 Analytical Results: Chromium. (3 sheets)

\begin{tabular}{|c|c|c|c|c|c|c|c|c|}
\hline $\begin{array}{l}\text { Simple: } \\
\text { Thumber } \\
\text { The }\end{array}$ & $\begin{array}{l}\text { Corte: } \\
\text { Segrnent }\end{array}$ & $\begin{array}{l}\text { Sult. } \\
\text { segnient }\end{array}$ & Ressili: & Duplisate & $\begin{array}{l}\text { Sampole } \\
\text { Meari }\end{array}$ & $\begin{array}{l}\text { Oreran } \\
\text { Hean }\end{array}$ & $\begin{array}{l}\text { Reso } \\
\text { (Mlcan) }\end{array}$ & $\begin{array}{l}\text { Irojented } \\
\text { Inxentory }\end{array}$ \\
\hline \multicolumn{3}{|c|}{ Sollider water tigest } & 1980 & .498 & (3) 98 & 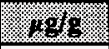 & 8 & 1.38 \\
\hline S96T002846 & $123: 4$ & Whole & 561 & 652 & 606.5 & \multirow[t]{6}{*}{553} & \multirow[t]{6}{*}{17.1} & \multirow[t]{6}{*}{1,620} \\
\hline S96T002547 & $123: 6$ & Lower $1 / 2$ & 196 & 221 & 208.5 & & & \\
\hline S96T002847 & $124: 3$ & Whole & 393 & 366 & 379.5 & & & \\
\hline S96T002848 & $124: 8$ & Upper $1 / 2$ & 898 & 785 & 841.5 & & & \\
\hline S96T002546 & $128: 2$ & Whole & 560 & 532 & 546 & & & \\
\hline S96T002849 & $128: 7$ & Upper $1 / 2$ & 726 & 746 & 736 & & & \\
\hline \multicolumn{3}{|c|}{ Compositest. Tukion aiget } & 1.1818 & 1.968 & $1.96 \mathrm{~g}$ & $18 \mathrm{~g}$ & 8 & 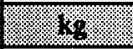 \\
\hline S96T001411 & 123 & $n / a$ & 2,570 & 2,880 & 2,720 & \multirow[t]{3}{*}{3,590} & \multirow[t]{3}{*}{13.5} & \multirow[t]{3}{*}{10,500} \\
\hline S96T001658 & 124 & $\mathrm{n} / \mathrm{a}$ & 3,610 & 3,700 & 3,660 & & & \\
\hline S96T001699 & 128 & $\mathrm{n} / \mathrm{a}$ & 4,350 & 4,440 & 4,400 & & & \\
\hline \multicolumn{3}{|c|}{ Coumposites: vrater digest } & $1.98 / 8$ & 1098 & $\sqrt{18 g / \mathrm{g}}$ & 108 & 8 & Y.8 \\
\hline S96T002515 & 123 & $n / a$ & 497 & 518 & 507.5 & \multirow[t]{3}{*}{530} & \multirow[t]{3}{*}{2.3} & \multirow[t]{3}{*}{1,550} \\
\hline S96T002516 & 124 & $n / a$ & 542 & 540 & 541 & & & \\
\hline S96T002517 & 128 & $n / a$ & 505 & 579 & 542 & & & \\
\hline \multicolumn{3}{|l|}{ Viquins: dinect } & . $19 \mathrm{~g} / \mathrm{mi}$ & rgmil & I. & ingtin! & $\%$ & 1.98 \\
\hline S96T000280 & $124: 3$ & $\mathrm{DL}$ & 127 & 128 & 127.5 & $n / a$ & $n / a$ & $n / a$ \\
\hline
\end{tabular}




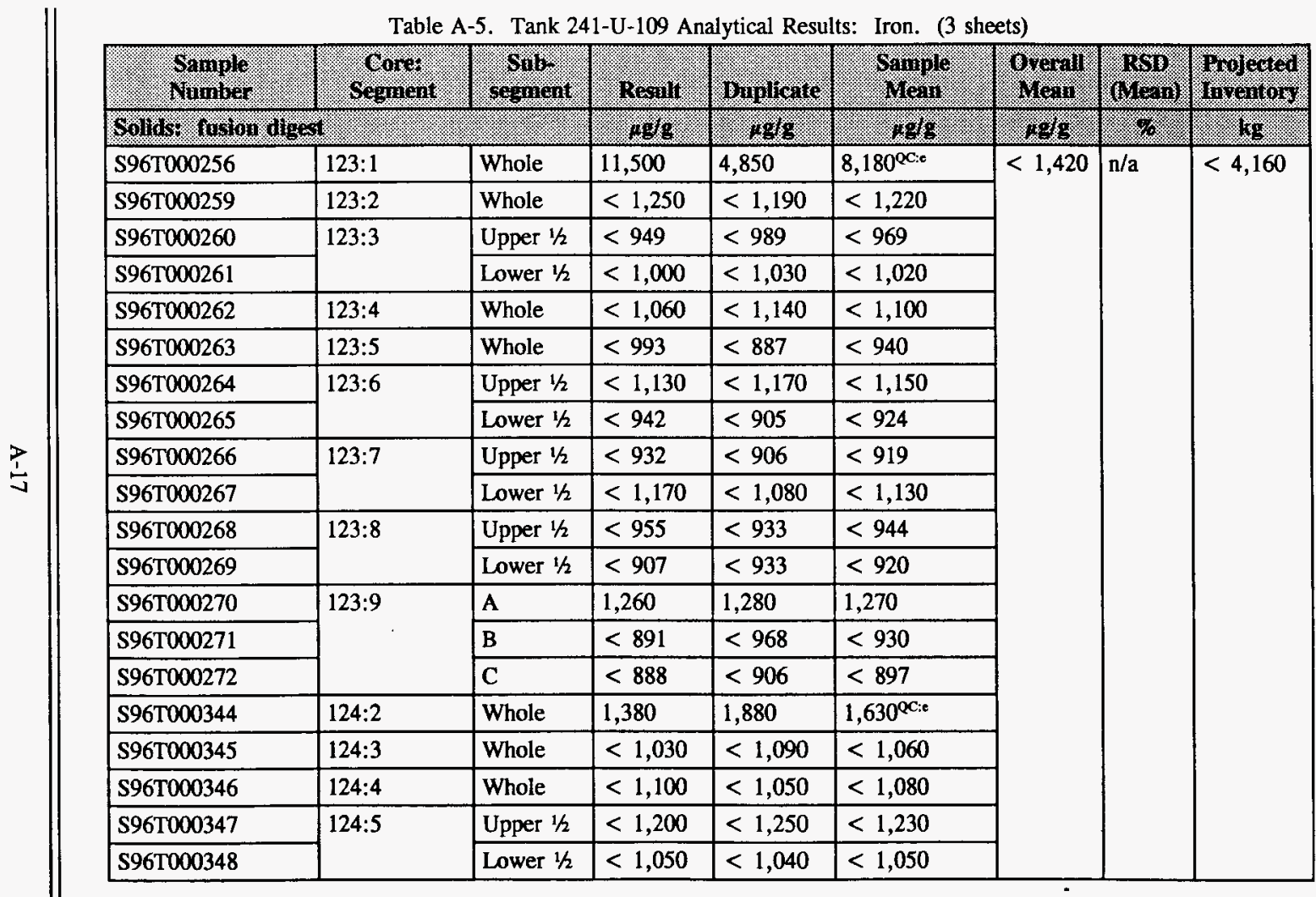




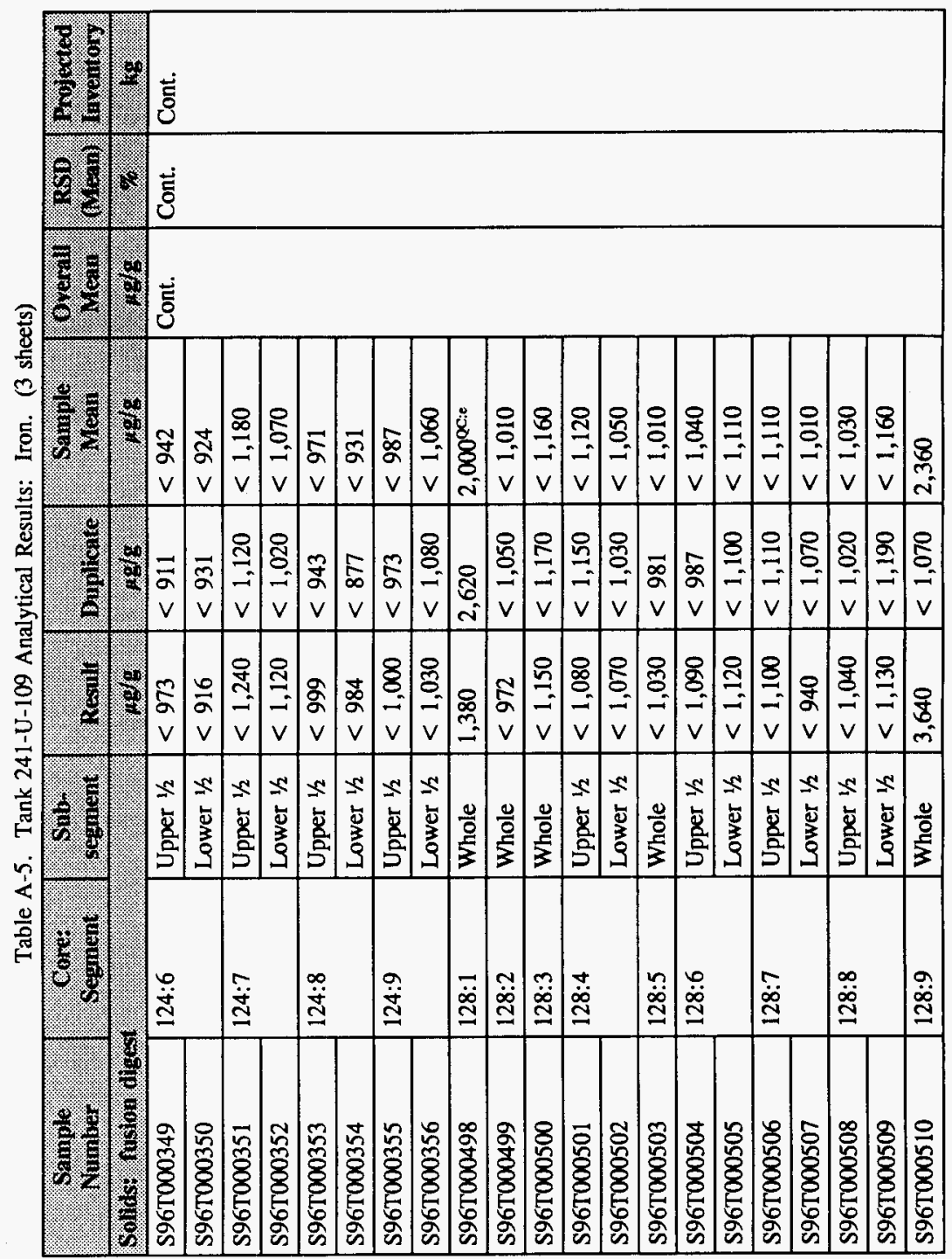


Table A-5. Tank 241-U-109 Analytical Results: Iron. (3 sheets)

\begin{tabular}{|c|c|c|c|c|c|c|c|c|}
\hline $\begin{array}{l}\text { Sample. } \\
\text { Vambier. }\end{array}$ & $\begin{array}{l}\text { Conrit) } \\
\text { Segment }\end{array}$ & $\begin{array}{l}\text { Silb } \\
\text { segrinent }\end{array}$ & Reralt & Mugilicale & $\begin{array}{l}\text { Sample } \\
\text { Mreari }\end{array}$ & $\begin{array}{l}\text { Orrarial } \\
\text { Meari }\end{array}$ & $\begin{array}{l}\text { Rsis: } \\
\text { (wean: }\end{array}$ & $\begin{array}{l}\text { Projected } \\
\text { Inventory }\end{array}$ \\
\hline Cromposings: & tingert & 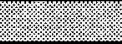 & 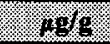 & 48 & 48 & $\operatorname{lng} 8$ & $\sqrt{8.2}$ & (18. \\
\hline S96T001411 & 123 & $\mathrm{n} / \mathrm{a}$ & $<1,010$ & $<987$ & $<999$ & \multirow[t]{3}{*}{$<971$} & \multirow[t]{3}{*}{$\mathrm{n} / \mathbf{a}$} & \multirow[t]{3}{*}{$<2,840$} \\
\hline S96T001658 & 124 & $n / a$ & $<971$ & $<975$ & $<973$ & & & \\
\hline S96T001699 & 128 & $\mathrm{n} / \mathrm{a}$ & $<911$ & $<972$ & $<942$ & & & \\
\hline \multicolumn{3}{|c|}{ Wiguids: direet } & 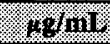 & $8 \mathrm{~g} / \mathrm{mil}$ & 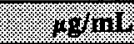 & 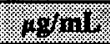 & \%) & kg. \\
\hline S96T000280 & $124: 3$ & $\mathrm{DL}$ & $<20.00$ & $<20.0$ & $<20.0$ & $\mathrm{n} / \mathrm{a}$ & $\mathrm{n} / \mathrm{a}$ & $n / a$ \\
\hline
\end{tabular}

Table A-6. Tank 241-U-109 Analytical Results: Manganese. (3 sheets)

\begin{tabular}{|c|c|c|c|c|c|c|c|c|}
\hline $\begin{array}{l}\text { Sample } \\
\text { Number }\end{array}$ & Cegrit & Sub: & Result & Bupticate & $\begin{array}{c}\text { Sampie } \\
\text { Wean }\end{array}$ & Operal & (793 & $\begin{array}{l}\text { Irojected } \\
\text { Inventory }\end{array}$ \\
\hline \multicolumn{3}{|c|}{ Sollds: fusion digest } & $14 \mathrm{~g} / \mathrm{s}$ & 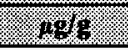 & 98 & $1,88_{18}$ & 6. & 168. \\
\hline S96T000256 & $123: 1$ & Whole & $<254$ & $<213$ & $<234$ & \multirow[t]{10}{*}{$<216$} & \multirow[t]{10}{*}{$n / a$} & \multirow[t]{10}{*}{$<632$} \\
\hline S96T000259 & $123: 2$ & Whole & $<251$ & $<238$ & $<245$ & & & \\
\hline S96T000260 & \multirow[t]{2}{*}{$123: 3$} & Upper $1 / 2$ & $<190$ & $<198$ & $<194$ & & & \\
\hline S96T000261 & & Lower $1 / 2$ & $<201$ & $<207$ & $<204$ & & & \\
\hline S96T000262 & $123: 4$ & Whole & $<214$ & $<228$ & $<221$ & & & \\
\hline S96T000263 & $123: 5$ & Whole & $<199$ & $<177$ & $<188$ & & & \\
\hline S96T000264 & \multirow[t]{2}{*}{$123: 6$} & Upper $1 / 2$ & $<226$ & $<231$ & $<229$ & & & \\
\hline S96T000265 & & Lower $1 / 2$ & $<188$ & $<181$ & $<185$ & & & \\
\hline S96T000266 & \multirow[t]{2}{*}{$123: 7$} & Upper $1 / 2$ & $<186$ & $<181$ & $<184$ & & & \\
\hline S96T000267 & & Lower $1 / 2$ & $<234$ & $<218$ & $<226$ & & & \\
\hline
\end{tabular}


Table A-6. Tank 241-U-109 Analytical Results: Manganese. (3 sheets)

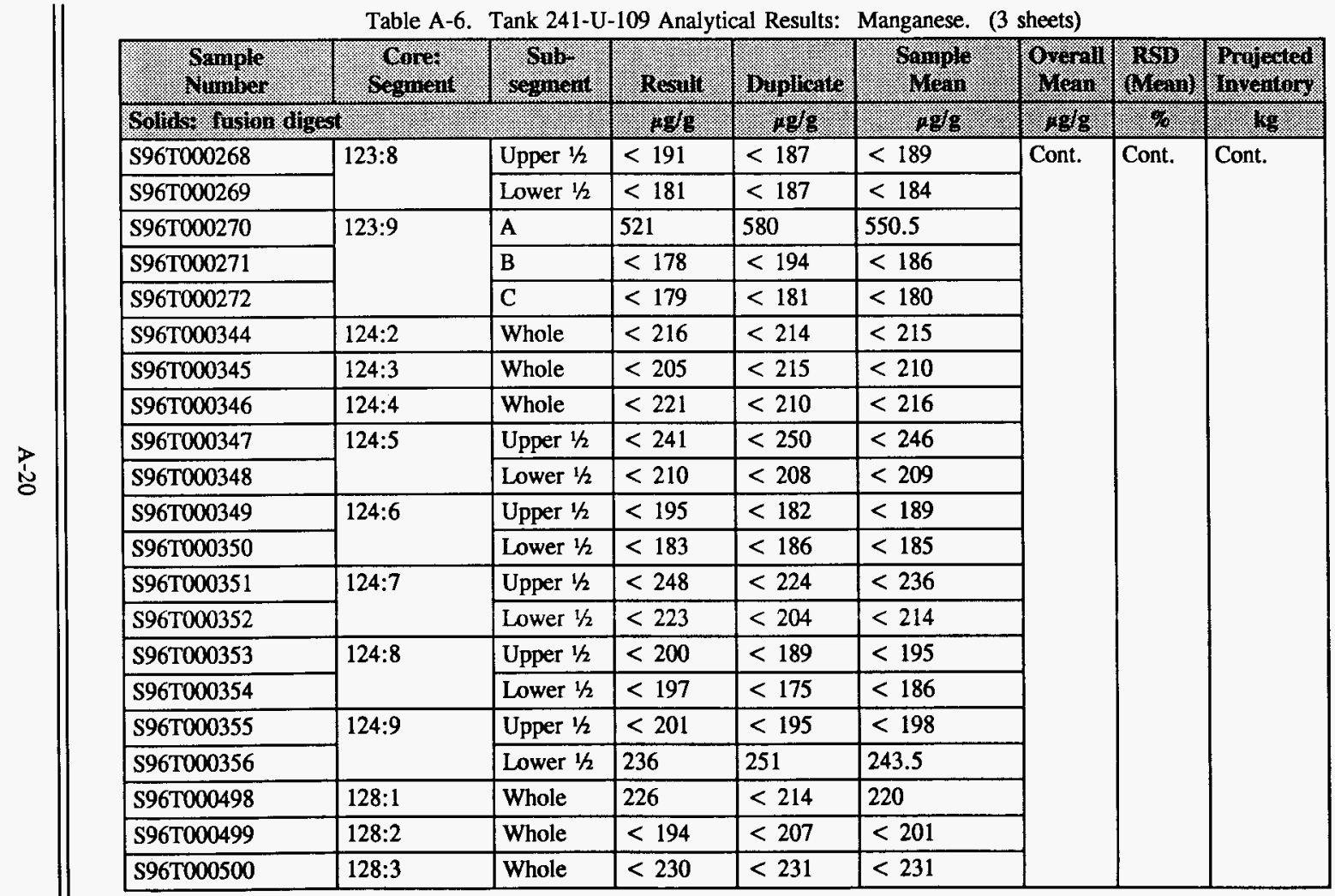


WHC-SD-WM-ER-609 Rev. 0

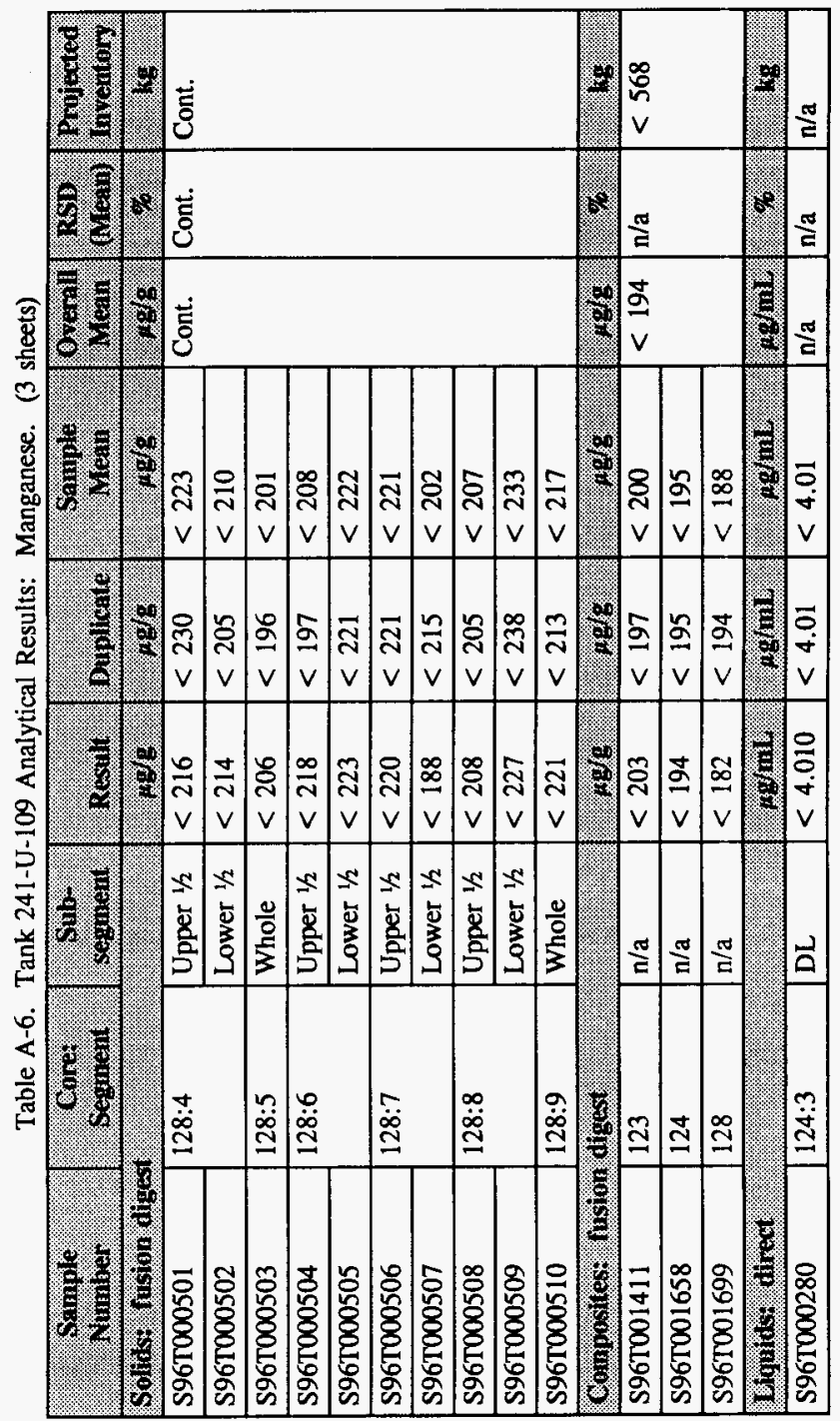


Table A-7. Tank 241-U-109 Analytical Results: Nickel. (3 sheets)

\begin{tabular}{|c|c|c|c|c|c|c|c|c|}
\hline Samplo & oforer & cosingut & Mrosilu & Buplicare & $\begin{array}{l}\text { Mring } \\
\text { mequ }\end{array}$ & 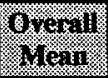 & $\begin{array}{l}\text { (is) } \\
(H, 1)\end{array}$ & $\begin{array}{l}\text { Wweted } \\
\text { montory }\end{array}$ \\
\hline \multicolumn{3}{|c|}{ 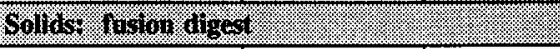 } & 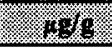 & . & $=1869$ & 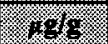 & \% & 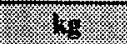 \\
\hline S96T000256 & $123: 1$ & Whole & $<508$ & $<426$ & $<467$ & \multirow[t]{20}{*}{$<421$} & \multirow[t]{20}{*}{$n / a$} & \multirow[t]{20}{*}{$<1,230$} \\
\hline S96T000259 & $123: 2$ & Whole & $<502$ & $<477$ & $<490$ & & & \\
\hline$\$ 96 \mathrm{~T} 000260$ & \multirow[t]{2}{*}{$123: 3$} & Upper $1 / 2$ & $<380$ & $<397$ & $<389$ & & & \\
\hline S96T000261 & & Lower $1 / 2$ & $<401$ & $<414$ & $<408$ & & & \\
\hline S96T000262 & $123: 4$ & Whole & $<425$ & $<457$ & $<441$ & & & \\
\hline S96T000263 & $123: 5$ & Whole & $<397$ & $<355$ & $<376$ & & & \\
\hline \$96T000264 & \multirow[t]{2}{*}{$123: 6$} & Upper $1 / 2$ & $<452$ & $<462$ & $<457$ & & & \\
\hline \$96T000265 & & Lower $1 / 2$ & $<377$ & $<362$ & $<370$ & & & \\
\hline S96T000266 & \multirow[t]{2}{*}{$123: 7$} & Upper $1 / 2$ & $<373$ & $<362$ & $<368$ & & & \\
\hline S96T000267 & & Lower $1 / 2$ & $<468$ & $<433$ & $<451$ & & & \\
\hline S96T000268 & \multirow[t]{2}{*}{$123: 8$} & Upper $1 / 2$ & $<382$ & $<373$ & $<378$ & & & \\
\hline S96T000269 & & Lower $1 / 2$ & $<363$ & $<373$ & $<368$ & & & \\
\hline$\$ 96 T 000270$ & \multirow[t]{3}{*}{$123: 9$} & A & $<477$ & $<419$ & $<448$ & & & \\
\hline S96T000271 & & B & $<356$ & $<387$ & $<372$ & & & \\
\hline S96T000272 & & C & $<355$ & $<362$ & $<359$ & & & \\
\hline S96T000344 & $124: 2$ & Whole & $<432$ & $<428$ & $<430$ & & & \\
\hline S96T000345 & $124: 3$ & Whole & $<411$ & $<430$ & $<421$ & & & \\
\hline \$96T000346 & 124:4 & Whole & $<442$ & $<419$ & $<431$ & & & \\
\hline \$96T000347 & \multirow[t]{2}{*}{$124: 5$} & Upper $1 / 2$ & $<481$ & $<500$ & $<491$ & & & \\
\hline S96T000348 & & Lower $1 / 2$ & $<411$ & $<416$ & $<414$ & & & \\
\hline
\end{tabular}


Table A-7. Tank 241-U-109 Analytical Results: Nickel. (3 sheets)

\begin{tabular}{|c|c|c|c|c|c|c|c|c|}
\hline Tumber & oronting & 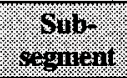 & Renill & Dinplicis & Sample & Whoring & 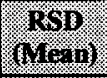 & 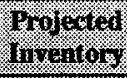 \\
\hline \multicolumn{3}{|c|}{ 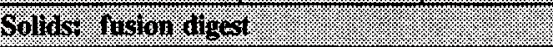 } & 68 & 196 & 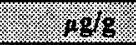 & 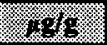 & \% & sy \\
\hline S96T000350 & & Lower $1 / 2$ & $<366$ & $<374$ & $<370$ & \multirow{20}{*}{ Cont. } & \multirow[t]{20}{*}{ Cont. } & \multirow[t]{20}{*}{ Cont. } \\
\hline S96T000351 & \multirow[t]{2}{*}{$124: 7$} & Upper $1 / 2$ & $<495$ & $<448$ & $<472$ & & & \\
\hline S96T000352 & & Lower $1 / 2$ & $<446$ & $<408$ & $<427$ & & & \\
\hline S96T000353 & \multirow[t]{2}{*}{$124: 8$} & Upper $1 / 2$ & $<400$ & $<377$ & $<389$ & & & \\
\hline S96T000354 & & Lower $1 / 2$ & $<394$ & $<351$ & $<373$ & & & \\
\hline$\$ 96 \mathrm{~T} 000355$ & \multirow[t]{2}{*}{$124: 9$} & Upper $1 / 2$ & $<401$ & $<389$ & $<395$ & & & \\
\hline S96T000356 & & Lower $1 / 2$ & $<413$ & $<432$ & $<423$ & & & \\
\hline S96T000498 & $128: 1$ & Whole & $<413$ & $<428$ & $<421$ & & & \\
\hline$\$ 96 \mathrm{~T} 000499$ & 128:2 & Whole & $<389$ & $<414$ & $<402$ & & & \\
\hline S96T000500 & $128: 3$ & Whole & $<460$ & $<462$ & $<461$ & & & \\
\hline S96T000501 & \multirow[t]{2}{*}{$128: 4$} & Upper $1 / 2$ & $<432$ & $<459$ & $<446$ & & & \\
\hline S96T000502 & & Lower $1 / 2$ & $<427$ & $<410$ & $<419$ & & & \\
\hline S96T000503 & $128: 5$ & Whole & $<412$ & $<394$ & $<403$ & & & \\
\hline S96T000504 & \multirow[t]{2}{*}{$128: 6$} & Upper $1 / 2$ & $<437$ & $<395$ & $<416$ & & & \\
\hline S96T000505 & & Lower $1 / 2$ & $<447$ & $<441$ & $<444$ & & & \\
\hline S96T000506 & \multirow[t]{2}{*}{$128: 7$} & Upper $1 / 2$ & $<431$ & $<442$ & $<437$ & & & \\
\hline S96T000507 & & Lower $1 / 2$ & $<376$ & $<430$ & $<403$ & & & \\
\hline S96T000508 & \multirow[t]{2}{*}{$128: 8$} & Upper $1 / 2$ & $<417$ & $<409$ & $<413$ & & & \\
\hline S96T000509 & & Lower $1 / 2$ & $<454$ & $<476$ & $<465$ & & & \\
\hline$\$ 96 \mathrm{~T} 000510$ & $128: 9$ & Whole & $<441$ & $<427$ & $<434$ & & & \\
\hline
\end{tabular}


Table A-7. Tank 241-U-109 Analytical Results: Nickel. (3 sheets)

\begin{tabular}{|c|c|c|c|c|c|c|c|c|}
\hline Sample & 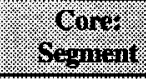 & Sulf & Resull & Buplisale & gampl & Wow11\% & 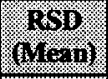 & Proverod \\
\hline \multicolumn{3}{|c|}{ Cromposinest frolon algest } & 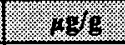 & 28 & $2 \mathrm{gl}$ & 89 & (8) & $\sqrt{1}$ \\
\hline S96T001411 & 123 & $n / a$ & 1,680 & 567 & $1,120^{\mathrm{OC}: \mathrm{e}}$ & \multirow[t]{3}{*}{1,840} & \multirow[t]{3}{*}{30.7} & \multirow[t]{3}{*}{5,390} \\
\hline S96T001658 & 124 & $\mathrm{n} / \mathrm{a}$ & 2,960 & 2,970 & 2,960 & & & \\
\hline S96T001699 & 128 & $n / a$ & 2,260 & 642 & 1,450 & & & \\
\hline \multicolumn{3}{|l|}{ Wquas oined } & 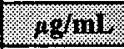 & Yy.ril & $48 / m$ & \% $1 / 111 \%$ & (x) & 48 \\
\hline S96T000280 & $124: 3$ & DL & $<8.020$ & $<8.02$ & $<8.02$ & $n / a$ & $n / a$ & $\mathrm{n} / \mathrm{a}$ \\
\hline
\end{tabular}

Table A-8. Tank 241-U-109 Analytical Results: Phosphorus. (3 sheets)

\begin{tabular}{|c|c|c|c|c|c|c|c|c|}
\hline Sample. & 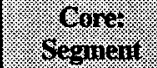 & $\begin{array}{l}\text { Sub } \\
\text { segment }\end{array}$ & Result & Buplica & Thmple & Oyeril & 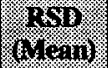 & $\begin{array}{l}\text { Pojected } \\
\text { mentong }\end{array}$ \\
\hline \multicolumn{2}{|c|}{ Solidy , ision diges } & & 40 & $189 / 4$ & 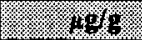 & 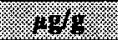 & w & 64 \\
\hline S96T000256 & $123: 1$ & Whole & $<5,080$ & $<4,260$ & $<4,670$ & \multirow[t]{10}{*}{$<8,000$} & \multirow[t]{10}{*}{$\mathrm{n} / \mathrm{a}$} & \multirow[t]{10}{*}{$<23,400$} \\
\hline S96T000259 & $123: 2$ & Whole & $<5,020$ & $<4,770$ & $<4,900$ & & & \\
\hline S96T000260 & \multirow[t]{2}{*}{$123: 3$} & Upper $1 / 2$ & $<3,800$ & $<3,970$ & $<3,890$ & & & \\
\hline S96T000261 & & Lower $1 / 2$ & $<4,010$ & $<4,140$ & $<4,080$ & & & \\
\hline S96T000262 & $123: 4$ & Whole & $<4,250$ & $<4,570$ & $<4,410$ & & & \\
\hline S96T000263 & $123: 5$ & Whole & $<3,970$ & $<3,550$ & $<3,760$ & & & \\
\hline S96T000264 & \multirow[t]{2}{*}{$123: 6$} & Upper $1 / 2$ & $<4,520$ & $<4,620$ & $<4,570$ & & & \\
\hline S96T000265 & & Lower $1 / 2$ & $<3,770$ & $<3,620$ & $<3,700$ & & & \\
\hline S96T000266 & \multirow[t]{2}{*}{$123: 7$} & Upper $1 / 2$ & $<3,730$ & $<3,620$ & $<3,680$ & & & \\
\hline S96T000267 & & Lower $1 / 2$ & $<4,680$ & $<4,330$ & $<4,510$ & & & \\
\hline
\end{tabular}


Table A-8. Tank 241-U-109 Analytical Results: Phosphorus. (3 sheets)

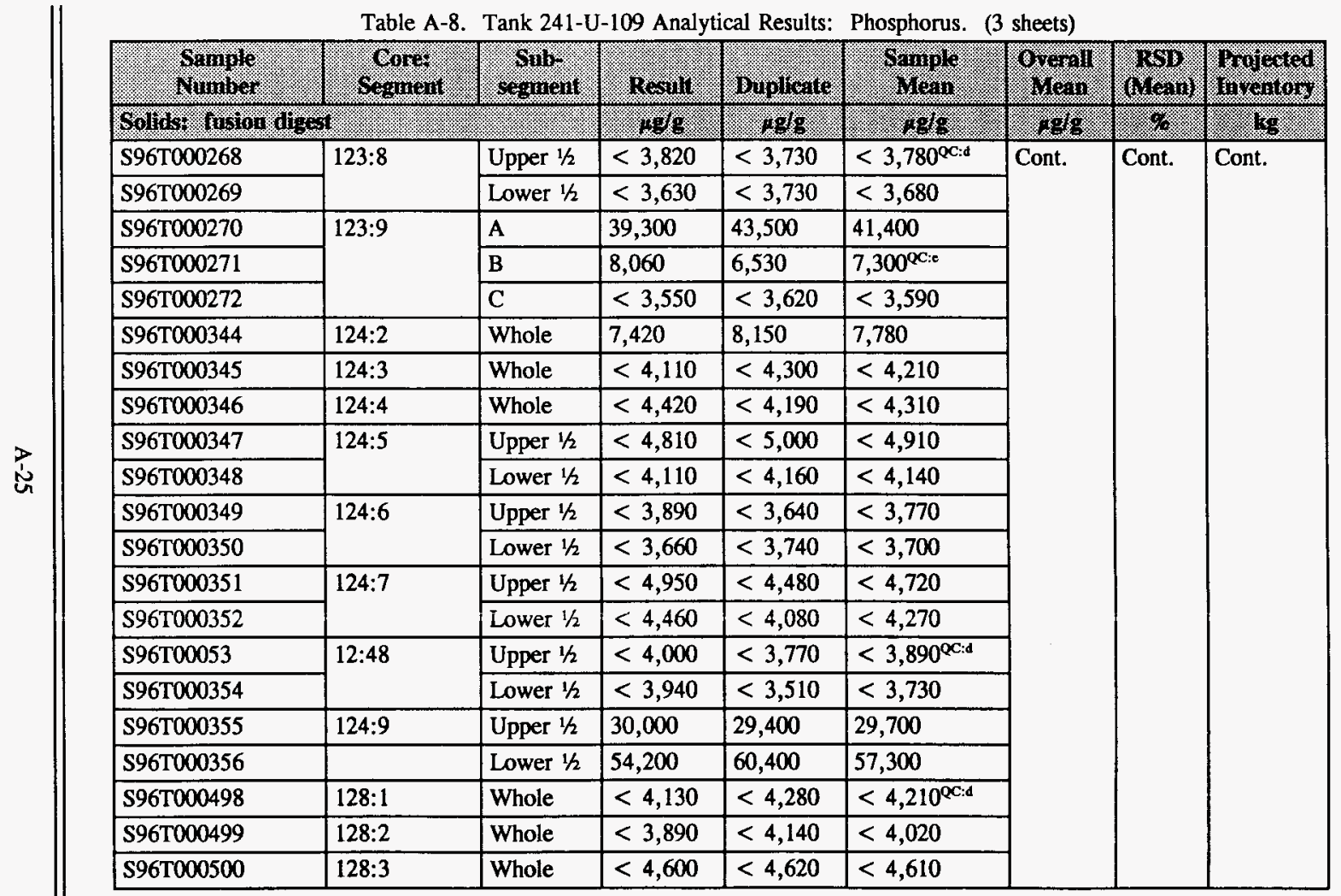


Table A-8. Tank 241-U-109 Analytical Results: Phosphorus. (3 sheets)

\begin{tabular}{|c|c|c|c|c|c|c|c|c|}
\hline $\begin{array}{l}\text { Sample } \\
\text { Miniter }\end{array}$ & Sorineri: & $\begin{array}{l}\text { Gill } \\
\text { setineil }\end{array}$ & $9 \mathrm{R}+\mathrm{sil}$ & Bipicale & 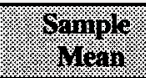 & 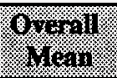 & How1 & 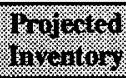 \\
\hline \multicolumn{3}{|c|}{ 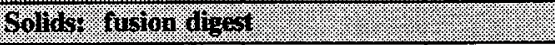 } & He/ & $\lg 18$ & 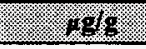 & 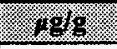 & 8 & 83 \\
\hline S96T000501 & \multirow[t]{2}{*}{$128: 4$} & Upper $1 / 2$ & $<4,320$ & $<4,590$ & $<4,460$ & \multirow[t]{10}{*}{ Cont. } & \multirow[t]{10}{*}{ Cont. } & \multirow[t]{10}{*}{ Cont. } \\
\hline \$96T000502 & & Lower $1 / 2$ & 8,640 & 7,240 & 7,940 & & & \\
\hline S96T000503 & $128: 5$ & Whole & $<4,120$ & $<3,940$ & $<4,030$ & & & \\
\hline S96T000504 & \multirow[t]{2}{*}{$128: 6$} & Upper $1 / 2$ & $<4,370$ & $<3,950$ & $<4,160$ & & & \\
\hline S96T000505 & & Lower $1 / 2$ & $<4,470$ & $<4,410$ & $<4,440$ & & & \\
\hline S96T000506 & \multirow[t]{2}{*}{$128: 7$} & Upper $1 / 2$ & $<4,310$ & $<4,420$ & $<4,370$ & & & \\
\hline \$96T000507 & & Lower $1 / 2$ & $<3,760$ & $<4,300$ & $<4,030$ & & & \\
\hline S96T000508 & \multirow[t]{2}{*}{$128: 8$} & Upper $1 / 2$ & $<4,170$ & $<4,090$ & $<4,130$ & & & \\
\hline S96T000509 & & Lower $1 / 2$ & 11,600 & 9,020 & $10,300^{\infty \mathrm{C}: e}$ & & & \\
\hline S96T000510 & $128: 9$ & Whole & 40,200 & 40,000 & 40,100 & & & \\
\hline \multicolumn{3}{|c|}{ 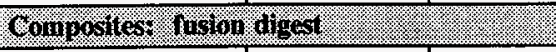 } & $18 \mathrm{gg}$ & 189 & (1. & 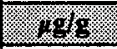 & $\%$ & 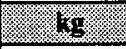 \\
\hline S96T001411 & 123 & $\mathrm{n} / \mathrm{a}$ & 4,260 & 5,720 & 4,990 & \multirow[t]{3}{*}{6,320} & \multirow[t]{3}{*}{12.4} & \multirow[t]{3}{*}{18,500} \\
\hline S96T001658 & 124 & $\mathrm{n} / \mathrm{a}$ & 6,000 & 6,570 & 6,280 & & & \\
\hline S96T001699 & 128 & $n / a$ & 7,580 & 7,810 & 7,700 & & & \\
\hline \multicolumn{3}{|c|}{ Grinds divet } & 49111 & 291113 & . & 28,131 & $\%$ & 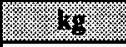 \\
\hline S96T000280 & $124: 3$ & DL & 839 & 838 & 838.5 & $\mathrm{n} / \mathrm{a}$ & $n / a$ & $n / a$ \\
\hline
\end{tabular}




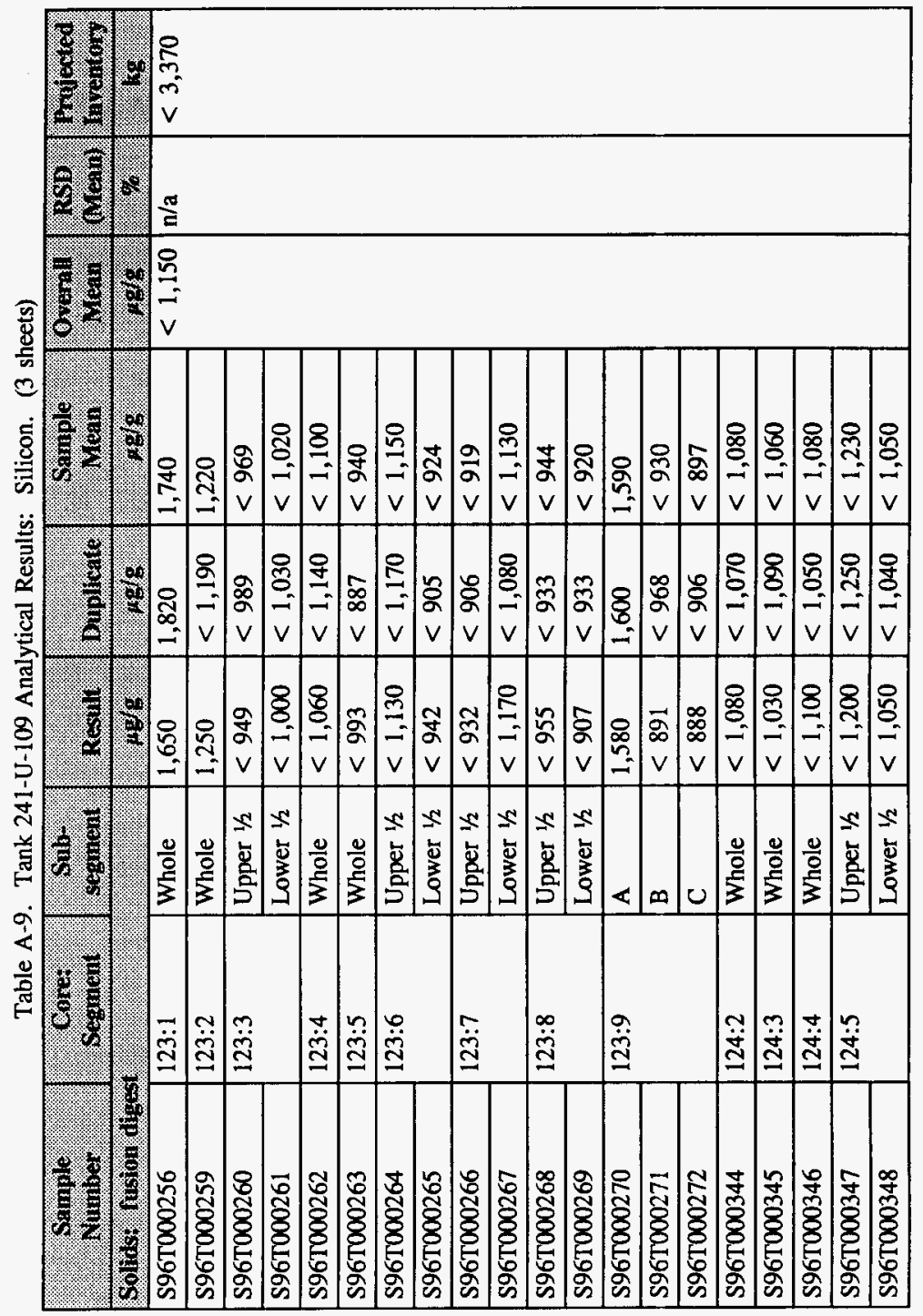


Table A-9. Tank 241-U-109 Analytical Results: Silicon. (3 sheets)

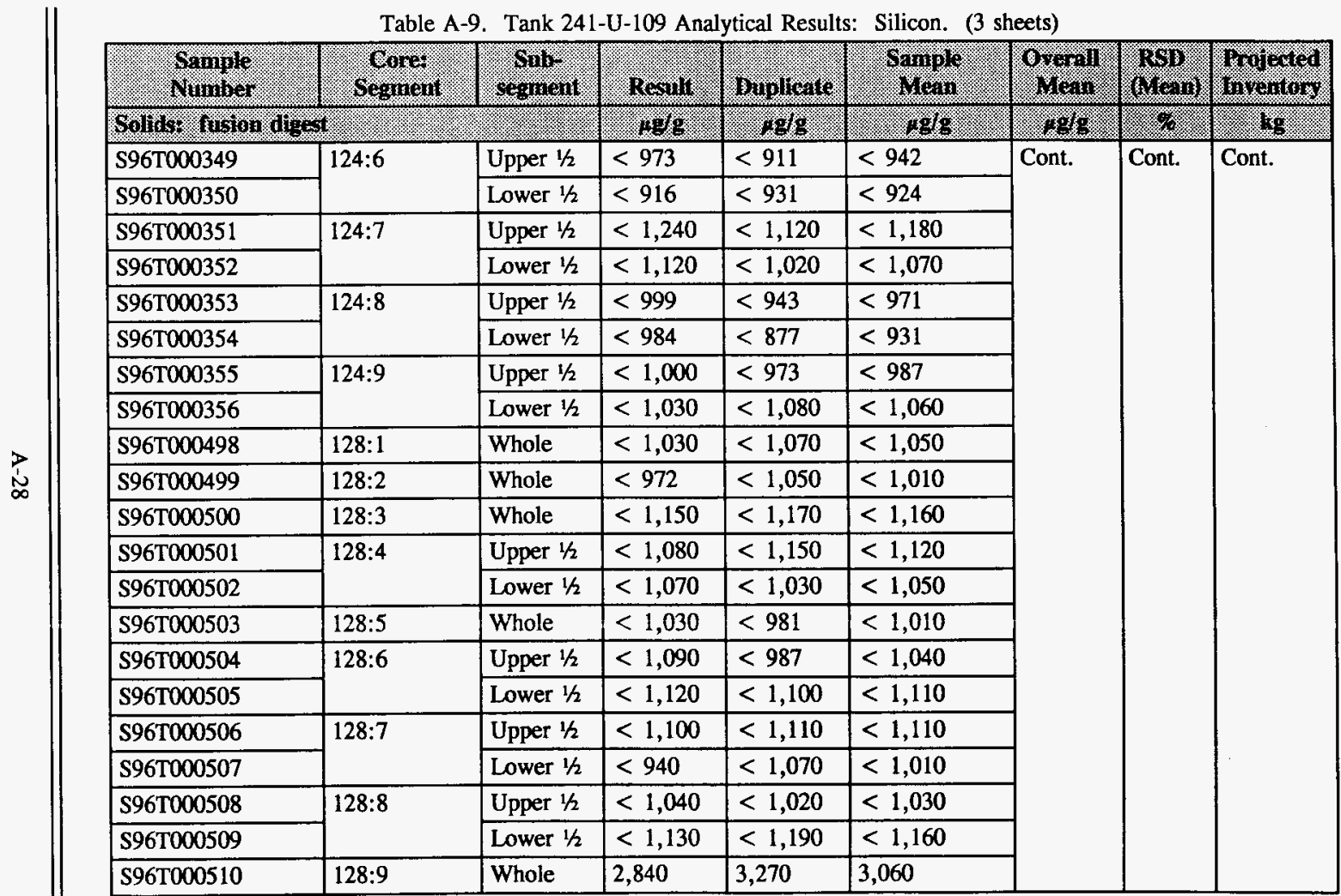


Table A-9. Tank 241-U-109 Analytical Results: Silicon. (3 sheets)

\begin{tabular}{|c|c|c|c|c|c|c|c|c|}
\hline $\begin{array}{l}\text { Gample } \\
\text { Whinost }\end{array}$ & \%oner. & 94911011 & Resuli: & Bupleate & mainel & 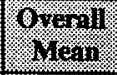 & 紋 & $\begin{array}{l}\text { Profored } \\
\text { molition }\end{array}$ \\
\hline \multicolumn{3}{|c|}{ Conposites r histon algest } & 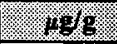 & $19 / 8$ & (19/5 & 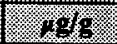 & (2.8. & $18 \mathrm{~g}$ \\
\hline S96T001411 & 123 & $n / a$ & $<1,010$ & $<987$ & $<999$ & \multirow[t]{3}{*}{$<1,580$} & \multirow[t]{3}{*}{$n / a$} & \multirow[t]{3}{*}{$<4,630$} \\
\hline S96T001658 & 124 & $\mathrm{n} / \mathrm{a}$ & 4,530 & $<975$ & 2,750 & & & \\
\hline S96T001699 & 128 & $n / a$ & $<911$ & 1,050 & 981 & & & \\
\hline \multicolumn{3}{|l|}{ Kiguids: dined } & ogg/nit. & oglini & og/mil & (4) & 8 & 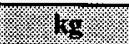 \\
\hline S96T000280 & $124: 3$ & $\mathrm{DL}$ & 56.70 & 57.00 & 56.85 & $n / a$ & $n / a$ & $\mathrm{n} / \mathrm{a}$ \\
\hline
\end{tabular}

Table A-10. Tank 241-U-109 Analytical Results: Sodium. (4 sheets)

\begin{tabular}{|c|c|c|c|c|c|c|c|c|}
\hline $81140 \%$ & 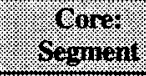 & Sib & 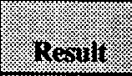 & Buplicate & Mrop & \% & (150 & Wrujerted \\
\hline \multicolumn{3}{|c|}{ 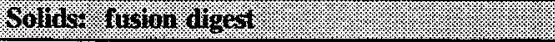 } & 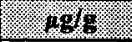 & 45 & 148 & igso & $1.8 \%$ & K8: \\
\hline$\$ 96 T 000256$ & $123: 1$ & Whole & $2.14 \mathrm{E}+05$ & $2.22 \mathrm{E}+05$ & $2.18 \mathrm{E}+05$ & \multirow[t]{10}{*}{$2.21 \mathrm{E}+05$} & \multirow[t]{10}{*}{3.0} & \multirow[t]{10}{*}{$6.47 \mathrm{E}+05$} \\
\hline S96T000259 & $123: 2$ & Whole & $2.40 \mathrm{E}+05$ & $2.31 \mathrm{E}+05$ & $2.36 \mathrm{E}+05$ & & & \\
\hline S96T000260 & \multirow[t]{2}{*}{$123: 3$} & Upper $1 / 2$ & $2.27 \mathrm{E}+05$ & $2.29 E+05$ & $2.28 \mathrm{E}+05$ & & & \\
\hline S96T000261 & & Lower $1 / 2$ & $2.42 \mathrm{E}+05$ & $2.41 \mathrm{E}+05$ & $2.42 \mathrm{E}+05^{\mathrm{QC:d}}$ & & & \\
\hline S96T000262 & $123: 4$ & Whole & $2.30 \mathrm{E}+05$ & $2.33 \mathrm{E}+05$ & $2.32 \mathrm{E}+05$ & & & \\
\hline S96T000263 & 123:5 & Whole & $2.40 \mathrm{E}+05$ & $2.27 \mathrm{E}+05$ & $2.34 \mathrm{E}+05$ & & & \\
\hline S96T000264 & \multirow[t]{2}{*}{$123: 6$} & Upper $1 / 2$ & $2.07 \mathrm{E}+05$ & $2.12 \mathrm{E}+05$ & $2.10 \mathrm{E}+05$ & & & \\
\hline S96T000265 & & Lower $1 / 2$ & $2.14 \mathrm{E}+05$ & $2.08 \mathrm{E}+05$ & $2.11 \mathrm{E}+05$ & & & \\
\hline \$96T000266 & \multirow[t]{2}{*}{$123: 7$} & Upper $1 / 2$ & $2.28 \mathrm{E}+05$ & $2.29 \mathrm{E}+05$ & $2.28 \mathrm{E}+05$ & & & \\
\hline S96T000267 & & Lower $1 / 2$ & $2.50 \mathrm{E}+05$ & $2.29 \mathrm{E}+05$ & $2.40 \mathrm{E}+05^{\mathrm{QC:d}}$ & & & \\
\hline
\end{tabular}




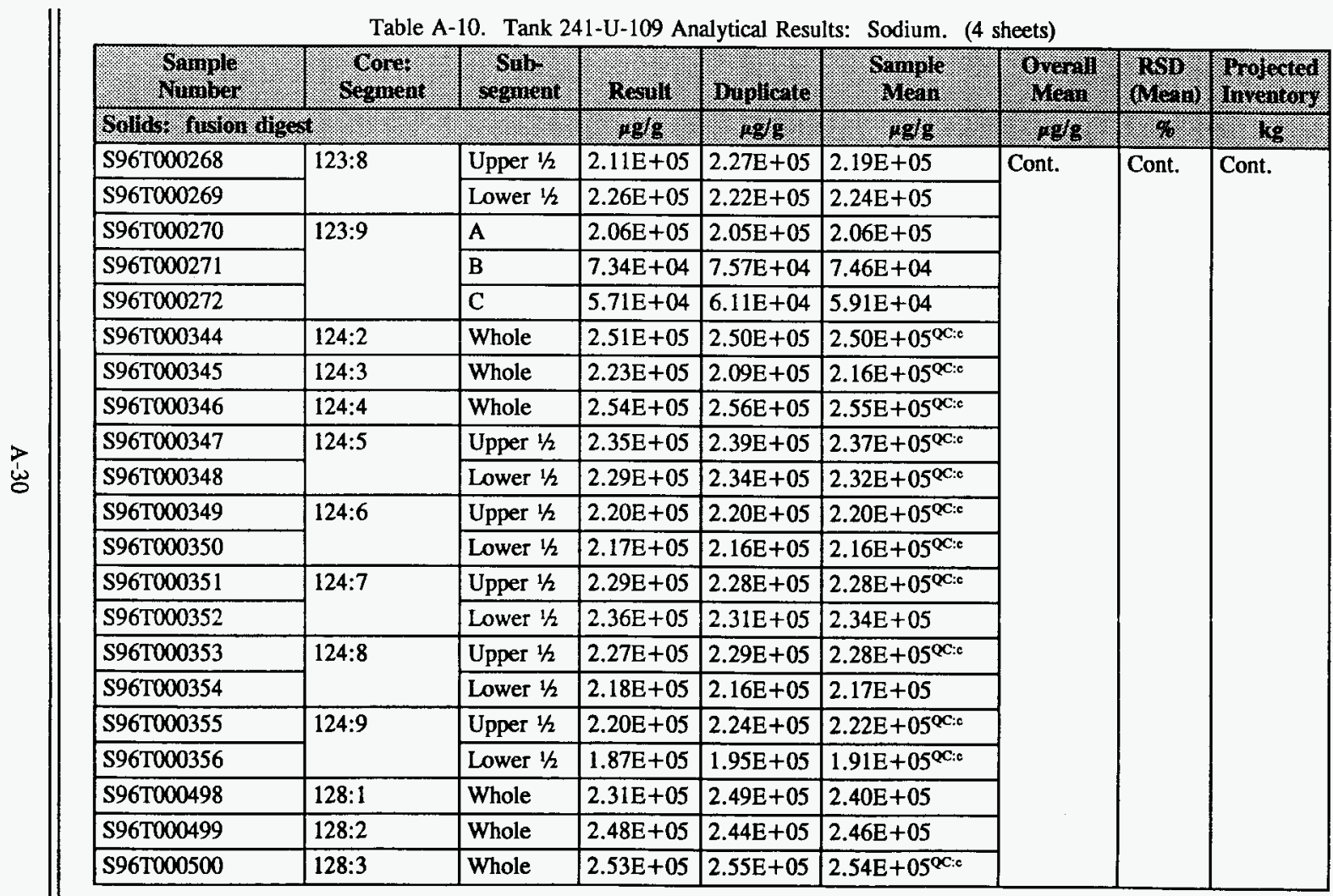




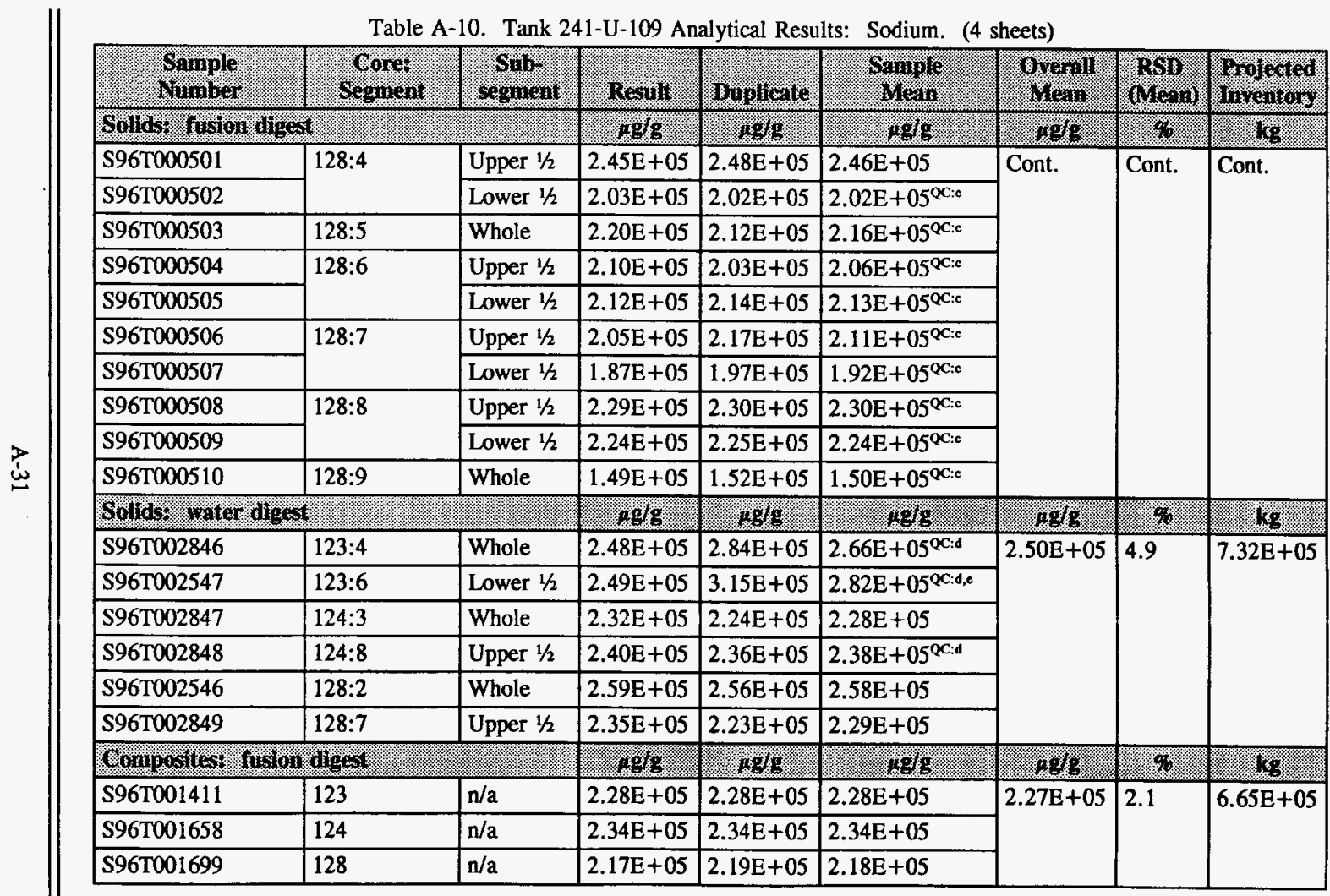


Table A-10. Tank 241-U-109 Analytical Results: Sodium. (4 sheets)

\begin{tabular}{|c|c|c|c|c|c|c|c|c|}
\hline $\begin{array}{c}\text { Sample } \\
\text { Shimber } \\
\end{array}$ & $\begin{array}{l}\text { Corr: } \\
\text { Segranen }\end{array}$ & $\begin{array}{l}\text { Surb } \\
\text { segment }\end{array}$ & Pevil & Duglicute & $\begin{array}{l}\text { Sampie } \\
\text { Mean. }\end{array}$ & $\begin{array}{l}\text { Overall } \\
\text { Viean }\end{array}$ & (2.51) & $\begin{array}{l}\text { Yrojected } \\
\text { Truemouy }\end{array}$ \\
\hline Conposites. & dig $=x$ & 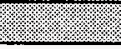 & rgs & $198 \mathrm{~g}$ & $48 \mathrm{~g}$ & .096 & 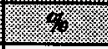 & $1 \%$ \\
\hline S96T002515 & 123 & $n / a$ & $2.45 \mathrm{E}+05$ & $2.37 \mathrm{E}+05$ & $2.41 \mathrm{E}+05$ & \multirow[t]{3}{*}{$2.38 \mathrm{E}+05$} & \multirow[t]{3}{*}{2.0} & \multirow[t]{3}{*}{$6.97 \mathrm{E}+05$} \\
\hline S96T002516 & 124 & $\mathrm{n} / \mathrm{a}$ & $2.43 \mathrm{E}+05$ & $2.44 \mathrm{E}+05$ & $2.44 \mathrm{E}+05$ & & & \\
\hline S96T002517 & 128 & $\mathrm{n} / \mathrm{a}$ & $2.34 \mathrm{E}+05$ & $2.23 \mathrm{E}+05$ & $2.28 \mathrm{E}+05$ & & & \\
\hline \multicolumn{2}{|l|}{ Thuids: direct } & 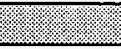 & optint & rgimi. & 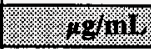 & 40,101 & 4 & $1 \%$ \\
\hline S96T000280 & $124: 3$ & DL & $1.77 \mathrm{E}+05$ & $1.76 \mathrm{E}+05$ & $1.76 \mathrm{E}+05$ & $\mathrm{n} / \mathrm{a}$ & $\mathbf{n} / \mathbf{a}$ & $\mathrm{n} / \mathrm{a}$ \\
\hline
\end{tabular}

Table A-11. Tank 241-U-109 Analytical Results: Uranium. (3 sheets)

\begin{tabular}{|c|c|c|c|c|c|c|c|c|}
\hline $\begin{array}{l}\text { Sample: } \\
\text { Vumber }\end{array}$ & $\begin{array}{l}\text { Corre: } \\
\text { Segruent }\end{array}$ & $\begin{array}{l}\text { Suib } \\
\text { segnient }\end{array}$ & Tesul: & Buplicates & $\begin{array}{c}\text { Sample: } \\
\text { Yean }\end{array}$ & $\begin{array}{c}\text { Operal } \\
\text { Venn }\end{array}$ & (MAO) & $\begin{array}{l}\text { Projouted } \\
\text { mernentor }\end{array}$ \\
\hline \multicolumn{3}{|c|}{ Solids rusion diges } & 198 & 489 & - & 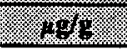 & $2 \%$ & 8 \\
\hline S96T000256 & 123:1 & Whole & $<12,700$ & $<10,800$ & $<11,800$ & \multirow[t]{10}{*}{$<10,600$} & \multirow[t]{10}{*}{$n / a$} & \multirow[t]{10}{*}{$<31,000$} \\
\hline S96T000259 & $123: 2$ & Whole & $<12,500$ & $<11,900$ & $<12,200$ & & & \\
\hline S96T000260 & \multirow[t]{2}{*}{$123: 3$} & Upper $1 / 2$ & $<9,490$ & $<9,890$ & $<9,690$ & & & \\
\hline S96T000261 & & Lower $1 / 2$ & $<10,000$ & $<10,300$ & $<10,200$ & & & \\
\hline S96T000262 & 123:4 & Whole & $<10,600$ & $<11,400$ & $<11,000$ & & & \\
\hline S96T000263 & $123: 5$ & Whole & $<9,930$ & $<8,870$ & $<9,400$ & & & \\
\hline S96T000264 & \multirow[t]{2}{*}{$123: 6$} & Upper $1 / 2$ & $<11,300$ & $<11,700$ & $<11,500$ & & & \\
\hline S96T000265 & & Lower $1 / 2$ & $<9,420$ & $<9,050$ & $<9,240$ & & & \\
\hline S96T000266 & \multirow[t]{2}{*}{$123: 7$} & Upper $1 / 2$ & $<9,320$ & $<9,060$ & $<9,190$ & & & \\
\hline S96T000267 & & Lower $1 / 2$ & $<11,700$ & $<10,800$ & $<11,300$ & & & \\
\hline
\end{tabular}




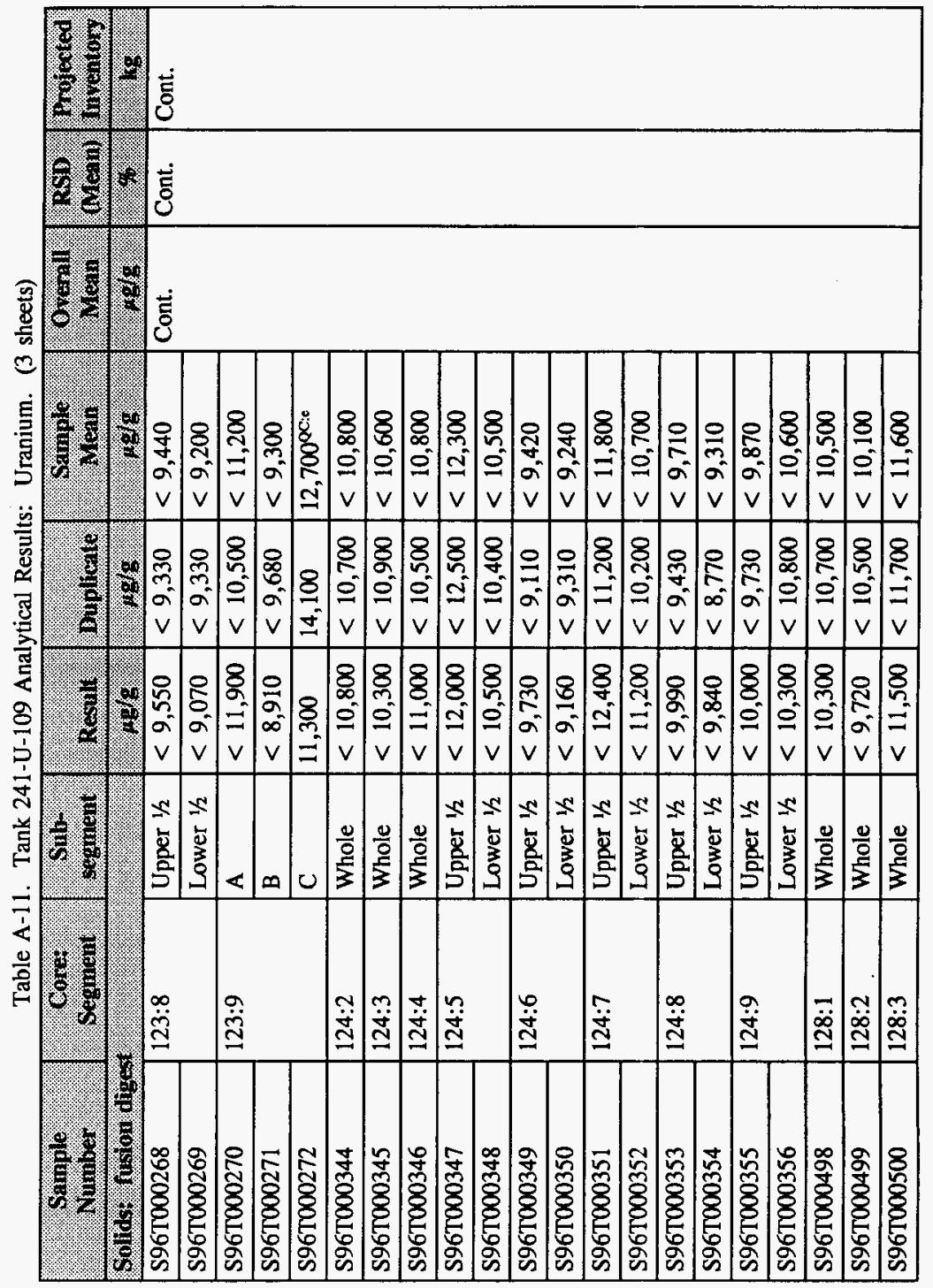


Table A-11. Tank 241-U-109 Analytical Results: Uranium. (3 sheets)

\begin{tabular}{|c|c|c|c|c|c|c|c|c|}
\hline $\begin{array}{l}\text { Sample } \\
\text { Number } \\
\text { nom }\end{array}$ & $\begin{array}{l}\text { Corr: } \\
\text { Segrient } \\
\end{array}$ & $\begin{array}{l}\text { Sulb: } \\
\text { segminat }\end{array}$ & Resul: & Buplicale & $\begin{array}{l}\text { Sample } \\
\text { Mean }\end{array}$ & $\begin{array}{l}\text { Orerail } \\
\text { Mean }\end{array}$ & $\begin{array}{l}\text { Tsis } \\
(\text { Menan }\end{array}$ & $\begin{array}{l}\text { Trojected } \\
\text { irrentory }\end{array}$ \\
\hline \multicolumn{2}{|c|}{ Solids: rusion aligest: } & 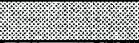 & ngle & 1098 & 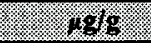 & igls: & 4 & sis \\
\hline S96T000501 & \multirow[t]{2}{*}{$128: 4$} & Upper $1 / 2$ & $<10,800$ & $<11,500$ & $<11,200$ & \multirow[t]{10}{*}{ Cont. } & \multirow[t]{10}{*}{ Cont. } & \multirow[t]{10}{*}{ Cont. } \\
\hline S96T000502 & & Lower $1 / 2$ & $<10,700$ & $<10,300$ & $<10,500$ & & & \\
\hline S96T000503 & $128: 5$ & Whole & $<10,300$ & $<9,810$ & $<10,100$ & & & \\
\hline S96T000504 & \multirow[t]{2}{*}{$128: 6$} & Upper $1 / 2$ & $<10,900$ & $<9,870$ & $<10,400$ & & & \\
\hline S96T000505 & & Lower $1 / 2$ & $<11,200$ & $<11,000$ & $<11,100$ & & & \\
\hline S96T000506 & \multirow[t]{2}{*}{$128: 7$} & Upper $1 / 2$ & $<11,000$ & $<11,100$ & $<11,100$ & & & \\
\hline S96T000507 & & Lower $1 / 2$ & $<9,400$ & $<10,700$ & $<10,100$ & & & \\
\hline S96T000508 & \multirow[t]{2}{*}{$128: 8$} & Upper $1 / 2$ & $<10,400$ & $<10,200$ & $<10,300$ & & & \\
\hline S96T000509 & & Lower $1 / 2$ & $<11,300$ & $<11,900$ & $<11,600$ & & & \\
\hline S96T000510 & $128: 9$ & Whole & $<11,000$ & $<10,700$ & $<10,900$ & & & \\
\hline \multicolumn{3}{|c|}{ Conivusitor. ICP (fusion diget) } & $.8 \mathrm{~g} g$ & 198. & 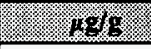 & 488. & 8. & (196. \\
\hline S96T001411 & 123 & $\mathrm{n} / \mathrm{a}$ & $<10,100$ & $<9,870$ & $<9,990$ & \multirow[t]{3}{*}{$<9,710$} & \multirow[t]{3}{*}{$\mathrm{n} / \mathrm{a}$} & \multirow[t]{3}{*}{$<28,400$} \\
\hline S96T001658 & 124 & n/a & $<9,710$ & $<9,750$ & $<9,730$ & & & \\
\hline S96T001699 & 128 & $n / a$ & $<9,110$ & $<9,720$ & $<9,420$ & & & \\
\hline \multicolumn{6}{|c|}{ Camposites phosphorescence (rusion digesi) } & & & \\
\hline S96T001411 & 123 & $\mathrm{n} / \mathrm{a}$ & 697 & 761.0 & 729.0 & \multirow[t]{3}{*}{428} & \multirow[t]{3}{*}{35.3} & \multirow[t]{3}{*}{1,250} \\
\hline S96T001658 & 124 & $\mathrm{n} / \mathrm{a}$ & 270 & 256.0 & 263.0 & & & \\
\hline S96T001699 & 128 & $\mathrm{n} / \mathrm{a}$ & 284 & 298.0 & 291.0 & & & \\
\hline \multicolumn{3}{|c|}{ Wiguids: direat } & (4) & egrme & $8 g \mathrm{ml}$ & gont & 8 & 16r: \\
\hline S96T000280 & $124: 3$ & DL & $<200$ & $<200$ & $<200$ & $n / a$ & $n / a$ & $n / a$ \\
\hline
\end{tabular}


Table A-12. Tank 241-U-109 Analytical Results: Chloride.

\begin{tabular}{|c|c|c|c|c|c|c|c|c|}
\hline $\begin{array}{l}\text { Sample. } \\
\text { Nimiber. }\end{array}$ & $\begin{array}{l}\text { Eoret } \\
\text { sepment }\end{array}$ & sulo & Re;111 & Bulpilate & Sarple & Groul & ThI & $\begin{array}{l}\text { proferted } \\
\text { meritory }\end{array}$ \\
\hline Whatus almor & 4 & & uprim. & grmit. & $98 / \mathrm{mL}$ & of 101 & 8 & 18. \\
\hline S96T000280 & $124: 3$ & DL & 3,540 & 3,580 & 3,560 & $n / a$ & $\mathrm{n} / \mathrm{a}$ & $\mathrm{n} / \mathrm{a}$ \\
\hline
\end{tabular}

Table A-13. Tank 241-U-109 Analytical Results: Fluoride.

\begin{tabular}{|c|c|c|c|c|c|c|c|c|}
\hline $\begin{array}{l}\text { Sanplo } \\
\text { Tumber }\end{array}$ & 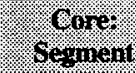 & sesine & Resili & Buplicate & 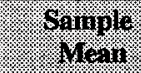 & Whon & 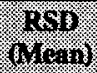 & 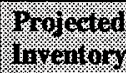 \\
\hline Gigains dines & & & 4 grinil & spini. & Ag/int & (28) & 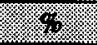 & 48 \\
\hline S96T000280 & $124: 3$ & DL & 374 & 223 & $298.4^{\text {QC:e }}$ & $n / a$ & $\mathrm{n} / \mathrm{a}$ & $n / a$ \\
\hline
\end{tabular}

Table A-14. Tank 241-U-109 Analytical Results: Nitrate. (3 sheets)

\begin{tabular}{|c|c|c|c|c|c|c|c|c|}
\hline Gample & Qorser & . & $\mathrm{R}=31 \mathrm{~m}$ & Buplicase & oniniple & 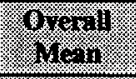 & MAB & 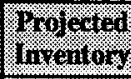 \\
\hline \multicolumn{2}{|c|}{ Solids water diger/ } & & 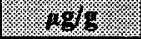 & 218 & 49 & $28 \mathrm{~g}$ & $\%$ & 18 \\
\hline \$96T000229 & $123: 1$ & Whole & $3.50 \mathrm{E}+05$ & $4.02 \mathrm{E}+05$ & $3.76 \mathrm{E}+05^{\alpha \mathrm{C} c}$ & \multirow[t]{6}{*}{$3.08 \mathrm{E}+05$} & \multirow[t]{6}{*}{12.8} & \multirow[t]{6}{*}{$9.02 \mathrm{E}+05$} \\
\hline \$96T000230 & $123: 2$ & Whole & $2.22 \mathrm{E}+05$ & $2.54 \mathrm{E}+05$ & $2.38 \mathrm{E}+05$ & & & \\
\hline S96T000231 & \multirow[t]{2}{*}{$123: 3$} & Upper $1 / 2$ & $5.92 \mathrm{E}+05$ & $5.80 \mathrm{E}+05$ & $5.86 \mathrm{E}+05^{\mathrm{QC:c}}$ & & & \\
\hline S96T000232 & & Lower $1 / 2$ & $5.90 \mathrm{E}+05$ & $5.95 \mathrm{E}+05$ & $5.92 \mathrm{E}+05$ & & & \\
\hline S96T000233 & 123:4 & Whole & $5.86 \mathrm{E}+05$ & $6.01 \mathrm{E}+05$ & $5.94 \mathrm{E}+05$ & & & \\
\hline S96T000234 & $123: 5$ & Whole & $4.80 \mathrm{E}+05$ & $5.38 \mathrm{E}+05$ & $5.09 \mathrm{E}+05$ & & & \\
\hline
\end{tabular}


Table A-14. Tank 241-U-109 Analytical Results: Nitrate. (3 sheets)

\begin{tabular}{|c|c|c|c|c|c|c|c|c|}
\hline $\begin{array}{l}\text { Sample } \\
\text { V Nmber }\end{array}$ & Oogrof & $\begin{array}{l}\text { Sijio } \\
\operatorname{segnou}\end{array}$ & Resin: & Baplicate & Wimple & \%oral & \% 1610 & Projerted \\
\hline \multicolumn{3}{|c|}{ Sollo, ware olger } & ralg & 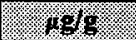 & 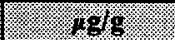 & 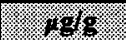 & S. & 138 \\
\hline S96T000235 & \multirow[t]{2}{*}{$123: 6$} & Upper $1 / 2$ & $2.64 \mathrm{E}+05$ & $3.06 \mathrm{E}+05$ & $2.85 \mathrm{E}+05$ & \multirow[t]{16}{*}{ Cont. } & \multirow[t]{16}{*}{ Cont. } & \multirow[t]{16}{*}{ Cont. } \\
\hline S96T000236 & & Lower $1 / 2$ & $3.11 \mathrm{E}+05$ & $2.89 \mathrm{E}+05$ & $3.00 \mathrm{E}+05$ & & & \\
\hline S96T000237 & $123: 7$ & Upper $1 / 2$ & $4.13 \mathrm{E}+05$ & $4.16 \mathrm{E}+05$ & $4.15 \mathrm{E}+05^{\alpha \mathrm{C}: c}$ & & & \\
\hline S96T000239 & \multirow[t]{2}{*}{$123: 8$} & Upper $1 / 2$ & $3.33 \mathrm{E}+05$ & $3.34 \mathrm{E}+05$ & $3.34 \mathrm{E}+05$ & & & \\
\hline S96T000240 & & Lower $1 / 2$ & $3.59 \mathrm{E}+05$ & $3.57 \mathrm{E}+05$ & $3.58 \mathrm{E}+05$ & & & \\
\hline S96T000241 & \multirow[t]{2}{*}{$123: 9$} & $\mathbf{A}$ & $1.05 \mathrm{E}+05$ & $1.06 \mathrm{E}+05$ & $1.06 \mathrm{E}+05$ & & & \\
\hline \$96T000242 & & B & 42,700 & 46,200 & $44,500^{\mathrm{Qc:d}}$ & & & \\
\hline S96T000359 & $124: 4$ & Whole & $4.01 \mathrm{E}+05$ & $4.30 \mathrm{E}+05$ & $4.16 \mathrm{E}+05$ & & & \\
\hline S96T000360 & \multirow[t]{2}{*}{$124: 5$} & Upper $1 / 2$ & $3.96 \mathrm{E}+05$ & $3.99 \mathrm{E}+05$ & $3.98 \mathrm{E}+05$ & & & \\
\hline S96T000361 & & Lower $1 / 2$ & $2.86 \mathrm{E}+05$ & $3.01 \mathrm{E}+05$ & $2.93 E+05$ & & & \\
\hline S96T000362 & \multirow[t]{2}{*}{$124: 6$} & Upper $1 / 2$ & $1.60 \mathrm{E}+05$ & $1.77 \mathrm{E}+05$ & $1.69 \mathrm{E}+05$ & & & \\
\hline S96T000363 & & Lower $1 / 2$ & $1.48 \mathrm{E}+05$ & $1.61 \mathrm{E}+05$ & $1.55 \mathrm{E}+05$ & & & \\
\hline S96T000364 & \multirow[t]{2}{*}{$124: 7$} & Upper $1 / 2$ & $3.92 \mathrm{E}+05$ & $3.81 \mathrm{E}+05$ & $3.86 \mathrm{E}+05$ & & & \\
\hline S96T000365 & & Lower $1 / 2$ & $4.58 \mathrm{E}+05$ & $4.41 \mathrm{E}+05$ & $4.49 \mathrm{E}+05$ & & & \\
\hline S96T000366 & \multirow[t]{2}{*}{$124: 8$} & Upper $1 / 2$ & $3.28 \mathrm{E}+05$ & $3.38 \mathrm{E}+05$ & $3.33 \mathrm{E}+05$ & & & \\
\hline S96T000367 & & Lower $1 / 2$ & $2.87 \mathrm{E}+05$ & $2.86 \mathrm{E}+05$ & $2.86 \mathrm{E}+05$ & & & \\
\hline
\end{tabular}




\begin{tabular}{|c|c|c|c|c|c|c|c|c|}
\hline $\begin{array}{l}\text { Sample: } \\
\text { Number. }\end{array}$ & $\begin{array}{l}\text { Corrt } \\
\text { Stgrnent }\end{array}$ & $\begin{array}{l}\text { Suit } \\
\text { segunent }\end{array}$ & Resmin & Diplicate & $\begin{array}{l}\text { Simple } \\
\text { Muan }\end{array}$ & $\begin{array}{l}\text { Oreran } \\
\text { Mcan }\end{array}$ & (Meso & $\begin{array}{l}\text { Irrojected } \\
\text { lavenuoy }\end{array}$ \\
\hline Solids water dige & 4. & (2:- & og/g & $48 / 8$ & $(18 / g$ & 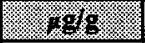 & 4 & 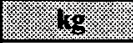 \\
\hline S96T000368 & \multirow[t]{2}{*}{$124: 9$} & Upper $1 / 2$ & $1.04 \mathrm{E}+05$ & 87,800 & 95,700 & \multirow[t]{15}{*}{ Cont. } & \multirow[t]{15}{*}{ Cont. } & \multirow[t]{15}{*}{ Cont. . } \\
\hline S96T000369 & & Lower $1 / 2$ & 38,900 & 46,800 & 42,800 & & & \\
\hline S96T000511 & $128: 1$ & Whole & $1.41 \mathrm{E}+05$ & $1.95 \mathrm{E}+05$ & $1.68 \mathrm{E}+05^{\mathrm{QC}: c}$ & & & \\
\hline S96T000512 & $128: 2$ & Whole & $4.46 \mathrm{E}+05$ & $4.67 \mathrm{E}+05$ & $4.56 \mathrm{E}+05$ & & & \\
\hline S96T000513 & $128: 3$ & Whole & $5.19 \mathrm{E}+05$ & $4.61 \mathrm{E}+05$ & $4.90 \mathrm{E}+05$ & & & \\
\hline S96T000514 & \multirow[t]{2}{*}{$128: 4$} & Upper $1 / 2$ & $4.92 \mathrm{E}+05$ & $3.04 \mathrm{E}+05$ & $3.98 \mathrm{E}+05^{Q \mathrm{C}: e}$ & & & \\
\hline S96T000515 & & Lower $1 / 2$ & $1.20 \mathrm{E}+05$ & $1.67 \mathrm{E}+05$ & $1.44 \mathrm{E}+05^{\mathrm{QC}: \mathrm{c}}$ & & & \\
\hline S96T000516 & $128: 5$ & Whole & $2.57 \mathrm{E}+05$ & $2.55 \mathrm{E}+05$ & $2.56 \mathrm{E}+05^{Q \mathrm{C}: 6}$ & & & \\
\hline S96T000517 & \multirow[t]{2}{*}{$128: 6$} & Upper $1 / 2$ & $1.42 \mathrm{E}+05$ & $1.79 \mathrm{E}+05$ & $1.60 \mathrm{E}+05^{\mathrm{QC}: \mathrm{e}}$ & & & \\
\hline S96T000518 & & Lower $1 / 2$ & $1.91 \mathrm{E}+05$ & $1.80 \mathrm{E}+05$ & $1.85 \mathrm{E}+05$ & & & \\
\hline S96T000519 & \multirow[t]{2}{*}{$128: 7$} & Upper $1 / 2$ & $1.96 \mathrm{E}+05$ & $2.16 \mathrm{E}+05$ & $2.06 \mathrm{E}+05$ & & & \\
\hline S96T000520 & & Lower $1 / 2$ & $1.06 \mathrm{E}+05$ & $1.05 \mathrm{E}+05$ & $1.06 \mathrm{E}+05$ & & & \\
\hline S96T000521 & \multirow[t]{2}{*}{$128: 8$} & Upper $1 / 2$ & $3.45 \mathrm{E}+05$ & $3.50 \mathrm{E}+05$ & $3.48 \mathrm{E}+05$ & & & \\
\hline S96T000522 & & Lower $1 / 2$ & $1.99 \mathrm{E}+05$ & $2.60 \mathrm{E}+05$ & $2.29 \mathrm{E}+05^{\mathrm{QC}: c, \mathrm{e}}$ & & & \\
\hline S96T000523 & 128:9 & Whole & 30,800 & 32,700 & 31,800 & & & \\
\hline Composites: vate & digest & (3) & 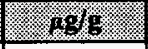 & 1.8ge & 2.80 & 1.geg & 80 & Igge \\
\hline S96T001412 & 123 & $n / a$ & $4.37 \mathrm{E}+05$ & $4.65 \mathrm{E}+05$ & $4.51 \mathrm{E}+05$ & \multirow[t]{3}{*}{$3.31 \mathrm{E}+05$} & \multirow[t]{3}{*}{18.4} & \multirow[t]{3}{*}{$9.69 \mathrm{E}+05$} \\
\hline S96T001659 & 124 & $\mathrm{n} / \mathrm{a}$ & $3.01 \mathrm{E}+05$ & $2.71 \mathrm{E}+05$ & $2.86 \mathrm{E}+05$ & & & \\
\hline S96T001700 & 128 & $\mathrm{n} / \mathrm{a}$ & $2.65 \mathrm{E}+05$ & $2.46 \mathrm{E}+05$ & $2.55 \mathrm{E}+05$ & & & \\
\hline Wraids direer & (1) & 4 & $182 / \mathrm{mu}$ & agrimi. & uglail & $18 \%$ mit. & 8 & he \\
\hline S96T000280 & $124: 3$ & DL & $3.64 \mathrm{E}+05$ & $3.55 \mathrm{E}+05$ & $3.59 \mathrm{E}+05$ & $n / a$ & $n / a$ & $\mathrm{n} / \mathrm{a}$ \\
\hline
\end{tabular}


Table A-15. Tank 241-U-109 Analytical Results: Nitrite.

\begin{tabular}{|c|c|c|c|c|c|c|c|c|}
\hline Sample. & Seponent & seprost & Resull & Duplicale & Womple & Horal & wes & moreror \\
\hline Haning olired & & & ng/nut & (19/m) & 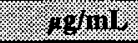 & gyinit. & 8 & 18 \\
\hline S96T000280 & $124: 3$ & DL & 43,900 & 41,900 & 42,900 & $\mathrm{n} / \mathrm{a}$ & $n / a$ & $\mathrm{n} / \mathrm{a}$ \\
\hline
\end{tabular}

Table A-16. Tank 241-U-109 Analytical Results: Oxalate.

\begin{tabular}{|c|c|c|c|c|c|c|c|c|}
\hline Gample & Sogringil & Sognent & Resull & ouplicate & oullo & 94oril & mos & minged \\
\hline I Iquids olred & & & $18 / 11$ & $16 \%$ min. & \%g/g11. & 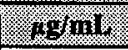 & $1 \%$ & $\sqrt{3}, 80$ \\
\hline S96T000280 & $124: 3$ & DL & $<1,070$ & $<1,070$ & $<1,070$ & $n / a$ & $n / a$ & $n / a$ \\
\hline
\end{tabular}

Table A-17. Tank 241-U-109 Analytical Results: Phosphate.

\begin{tabular}{|c|c|c|c|c|c|c|c|c|}
\hline $\begin{array}{l}\text { Gample } \\
\text { Numiver. }\end{array}$ & Segrient & sepmen & pering: & Quplicate & Solnow & $6 \%$ \% & $\frac{1+3 B}{(1 \% 213)}$ & Whold \\
\hline Whatist oficot & & & Hefris & 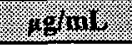 & 18111 & $49 \mathrm{~min}$ & 3 & 18 \\
\hline S96T000280 & $124: 3$ & DL & 5,850 & 6,090 & 5,970 & $\mathrm{n} / \mathbf{a}$ & $\mathrm{n} / \mathrm{a}$ & $\mathrm{n} / \mathrm{a}$ \\
\hline
\end{tabular}

Table A-18. Tank 241-U-109 Analytical Results: Sulfate.

\begin{tabular}{|c|c|c|c|c|c|c|c|c|}
\hline Shinolo & sedicin & orion & Result & Bupligato & $4 x^{2}$ & $64 \%$ & $\frac{1910}{(20)}$ & 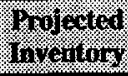 \\
\hline 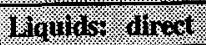 & & & rgmin: & $849 \mathrm{mi}$ & $18.5 \mathrm{mil}$. & (4g/ini. & 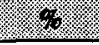 & 80 \\
\hline \$96T000280 & $124: 3$ & $\overline{D L}$ & 11,200 & 11,000 & 11,100 & $\mathrm{n} / \mathrm{a}$ & $n / a$ & $n / a$ \\
\hline
\end{tabular}


Table A-19. Tank 241-U-109 Analytical Results: Cesium-137. (3 sheets)

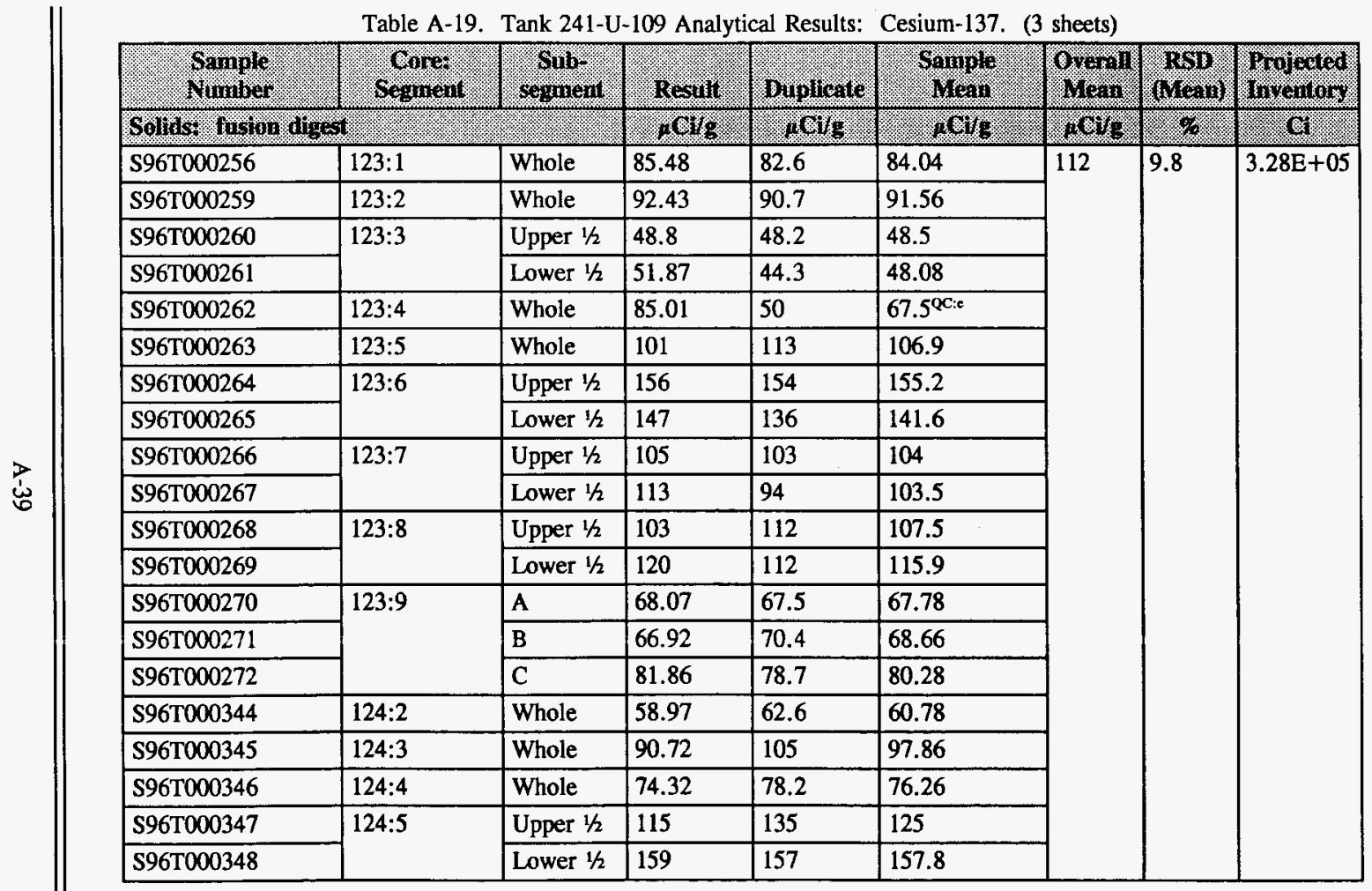


Table A-19. Tank 241-U-109 Analytical Results: Cesium-137. (3 sheets)

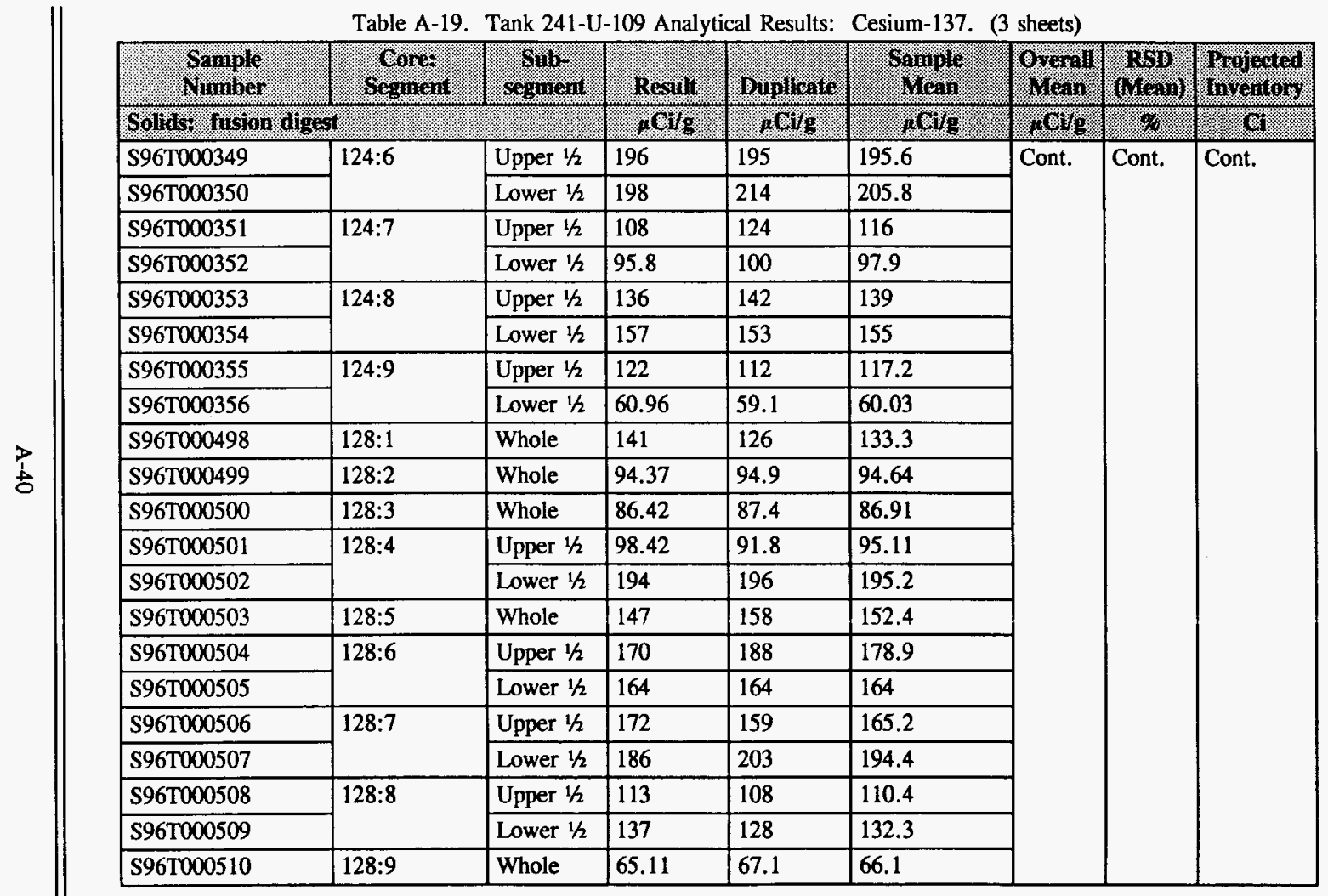




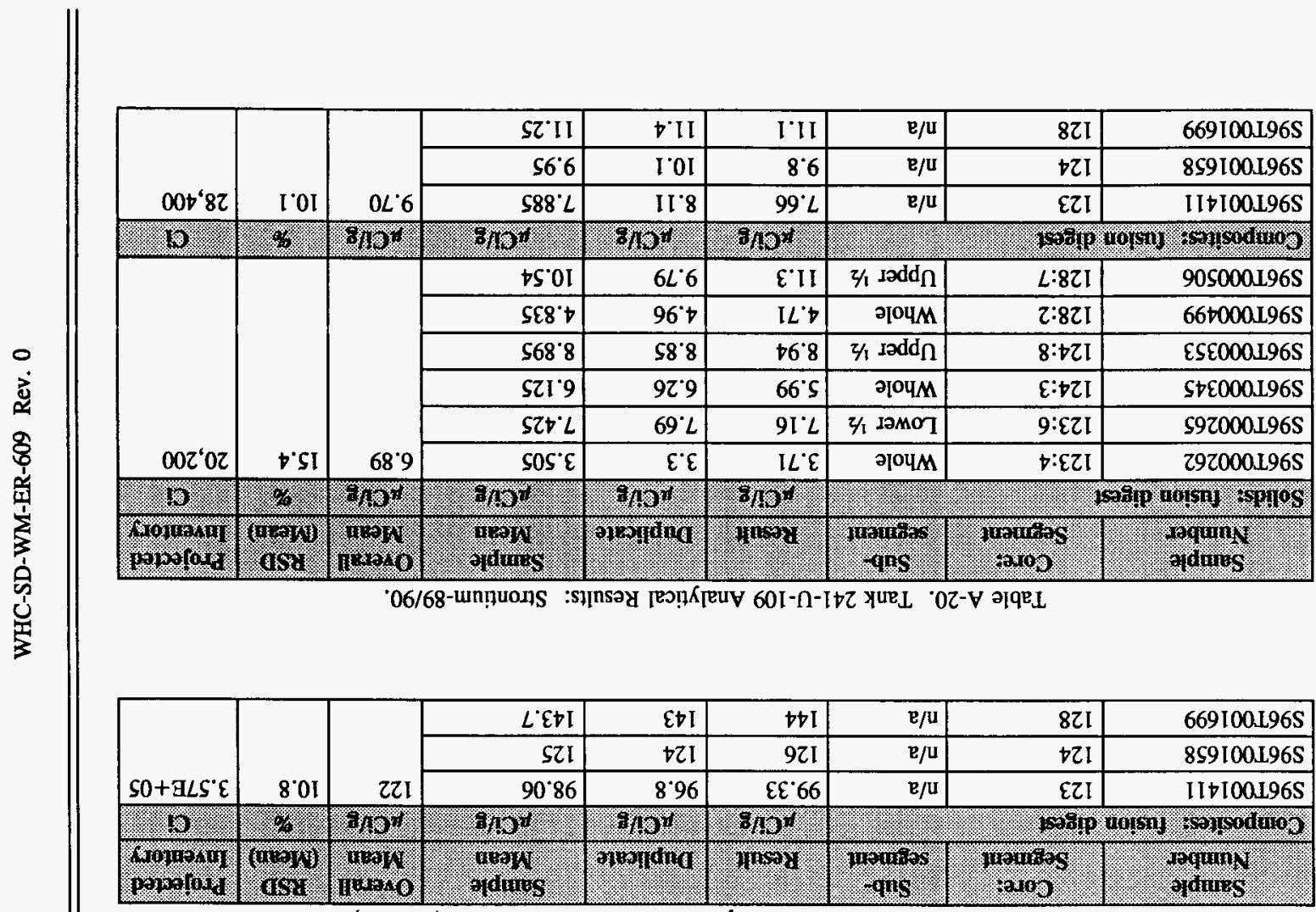

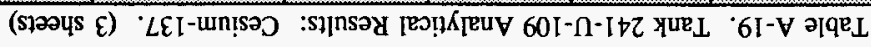




\begin{tabular}{|c|c|c|c|c|c|c|c|c|}
\hline $\begin{array}{l}\text { Somple } \\
\text { Number }\end{array}$ & $\begin{array}{l}\text { Comer } \\
\text { Segment. }\end{array}$ & $\begin{array}{l}\text { Sulb - } \\
\text { segment }\end{array}$ & Resilt: & Duplicate & $\begin{array}{l}\text { Sample } \\
\text { Mean }\end{array}$ & orerall & $\begin{array}{c}\text { Rop } \\
\text { Mean }\end{array}$ & $\begin{array}{l}\text { Prolichtal } \\
\text { Inventory }\end{array}$ \\
\hline \multicolumn{3}{|c|}{ Sollosi fusion digest } & 1418 & (2) 19 & 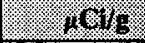 & 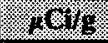 & . & (1) \\
\hline S96T000256 & 123:1 & Whole & 0.0236 & 0.0267 & $0.0251^{Q C: c}$ & \multirow[t]{21}{*}{0.0371} & \multirow[t]{21}{*}{20.9} & \multirow[t]{21}{*}{109} \\
\hline S96T000259 & 123:2 & Whole & 0.0157 & 0.0222 & $0.0190^{Q C: c, c}$ & & & \\
\hline S96T000260 & \multirow[t]{2}{*}{$123: 3$} & Upper $1 / 2$ & 0.0124 & 0.0129 & 0.0126 & & & \\
\hline S96T000261 & & Lower $1 / 2$ & 0.0124 & 0.00540 & $0.00890^{\alpha C:}$ & & & \\
\hline S96T000262 & $123: 4$ & Whole & 0.0553 & 0.0302 & $0.0428^{Q C: c}$ & & & \\
\hline S96T000263 & $123: 5$ & Whole & 0.0324 & 0.0261 & $0.0292^{Q C: e}$ & & & \\
\hline \$96T000265 & 123:6 & Lower $1 / 2$ & 0.0282 & 0.0292 & 0.0287 & & & \\
\hline S96T000267 & $123: 7$ & Lower $1 / 2$ & 0.0163 & 0.0110 & $0.0136^{\alpha C: c, e}$ & & & \\
\hline S96T000269 & 123:8 & Lower $1 / 2$ & 0.0158 & 0.0160 & 0.0159 & & & \\
\hline S96T000272 & $123: 9$ & $\mathrm{C}$ & 0.0114 & 0.0114 & $0.0114^{Q \mathrm{C}: \mathrm{c}}$ & & & \\
\hline S96T000344 & $124: 2$ & Whole & 0.0655 & 0.0713 & 0.0684 & & & \\
\hline S96T000345 & $124: 3$ & Whole & 0.0452 & 0.0513 & 0.0483 & & & \\
\hline S96T000346 & $124: 4$ & Whole & 0.0321 & 0.0307 & 0.0314 & & & \\
\hline S96T000347 & \multirow[t]{2}{*}{$124: 5$} & Upper $1 / 2$ & 0.0243 & 0.0461 & $0.0352^{\mathrm{QC}: \mathrm{e}}$ & & & \\
\hline S96T000348 & & Lower $1 / 2$ & 0.0203 & 0.0195 & 0.0199 & & & \\
\hline S96T000349 & \multirow[t]{2}{*}{$124: 6$} & Upper $1 / 2$ & 0.0363 & 0.0417 & 0.0390 & & & \\
\hline S96T000350 & & Lower $1 / 2$ & 0.0393 & 0.0393 & 0.0393 & & & \\
\hline S96T000351 & \multirow[t]{2}{*}{$124: 7$} & Upper $1 / 2$ & 0.0192 & 0.0215 & 0.0204 & & & \\
\hline S96T000352 & & Lower $1 / 2$ & 0.0175 & 0.0125 & $0.0150^{\alpha C: e}$ & & & \\
\hline S96T000353 & \multirow[t]{2}{*}{$124: 8$} & Upper $1 / 2$ & 0.0247 & 0.0250 & 0.0249 & & & \\
\hline S96T000354 & & Lower $1 / 2$ & 0.0428 & 0.0496 & 0.0462 & & & \\
\hline
\end{tabular}




\begin{tabular}{|c|c|c|c|c|c|c|c|c|}
\hline 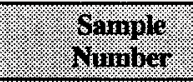 & $\begin{array}{l}\text { Corti } \\
\text { Segrient }\end{array}$ & $\begin{array}{l}\text { Surt } \\
\text { segment }\end{array}$ & Resily & Ouplicate: & $\begin{array}{l}\text { Sample } \\
\text { Nern }\end{array}$ & $\begin{array}{c}\text { orerall } \\
\text { Mern }\end{array}$ & $\begin{array}{l}\text { ass } \\
\text { (Mrean }\end{array}$ & $\begin{array}{l}\text { irolocted } \\
\text { inzentory }\end{array}$ \\
\hline \multicolumn{3}{|c|}{ Solids rusion digert } & reve & $101 / g$ & $1 \mathrm{Cl}_{\mathrm{s}}$ & (a) & 8. & (3) \\
\hline S96T000355 & \multirow[t]{2}{*}{$124: 9$} & Upper $1 / 2$ & 0.0476 & 0.0596 & $0.0536^{\mathrm{QC:e}}$ & \multirow[t]{15}{*}{ Cont. } & \multirow[t]{15}{*}{ Cont. } & \multirow[t]{15}{*}{ Cont. } \\
\hline S96T000356 & & Lower $1 / 2$ & 0.0870 & 0.0881 & 0.0875 & & & \\
\hline S96T000498 & 128:1 & Whole & 0.149 & 0.151 & 0.150 & & & \\
\hline S96T000499 & $128: 2$ & Whole & 0.0345 & 0.0419 & $0.0382^{\alpha C: c}$ & & & \\
\hline S96T000500 & $128: 3$ & Whole & 0.0259 & 0.0193 & $0.0226^{\mathrm{QC:e}}$ & & & \\
\hline S96T000501 & \multirow[t]{2}{*}{$128: 4$} & Upper $1 / 2$ & 0.0473 & 0.0348 & $0.0411^{Q C: e}$ & & & \\
\hline S96T000502 & & Lower $1 / 2$ & 0.0576 & 0.0659 & 0.0617 & & & \\
\hline S96T000503 & $128: 5$ & Whole & 0.0161 & 0.0135 & 0.0148 & & & \\
\hline S96T000504 & \multirow[t]{2}{*}{$128: 6$} & Upper $1 / 2$ & 0.0229 & 0.0286 & $0.0258^{\mathrm{QC}: \mathrm{e}}$ & & & \\
\hline S96T000505 & & Lower $1 / 2$ & 0.0256 & 0.0151 & $0.0204^{\mathrm{QC:c}}$ & & & \\
\hline S96T000506 & \multirow[t]{2}{*}{$128: 7$} & Upper $1 / 2$ & 0.0272 & 0.0210 & $0.0241^{\text {OC:ce,e }}$ & & & \\
\hline S96T000507 & & Lower $1 / 2$ & 0.0341 & 0.0324 & 0.0333 & & & \\
\hline S96T000508 & \multirow[t]{2}{*}{$128: 8$} & Upper $1 / 2$ & 0.0252 & 0.0224 & 0.0238 & & & \\
\hline S96T000509 & & Lower $1 / 2$ & 0.0481 & 0.0613 & $0.0547^{Q C: E}$ & & & \\
\hline S96T000510 & $128: 9$ & Whole & 0.0642 & 0.0480 & $0.0561^{\mathrm{QC:c}}$ & & & \\
\hline \multicolumn{3}{|c|}{ Conposilost fision diget: } & 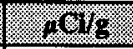 & $\sqrt{16} 18$ & $1=1.618$ & 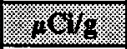 & 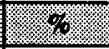 & 9. \\
\hline S96T001411 & 123 & $\mathrm{n} / \mathrm{a}$ & 0.0378 & 0.0285 & $0.0331^{\mathrm{QC}: \mathrm{e}}$ & \multirow[t]{3}{*}{0.0350} & \multirow[t]{3}{*}{4.6} & \multirow[t]{3}{*}{102} \\
\hline S96T001658 & 124 & $n / a$ & 0.0349 & 0.0337 & 0.0343 & & & \\
\hline S96T001699 & 128 & $\mathrm{n} / \mathrm{a}$ & 0.0402 & 0.0353 & 0.0377 & & & \\
\hline \multicolumn{3}{|c|}{ 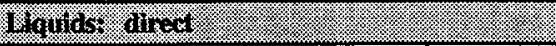 } & G. & $4 \mathrm{CV}$ mi & y & Eint & (2) & (1) \\
\hline S96T000280 & $124: 3$ & $\mathrm{DL}$ & 0.00107 & $<9.27 \mathrm{E}-04$ & $9.99 \mathrm{E}-04$ & $n / a$ & $n / a$ & $n / a$ \\
\hline
\end{tabular}


WHC-SD-WM-ER-609 Rev. 0

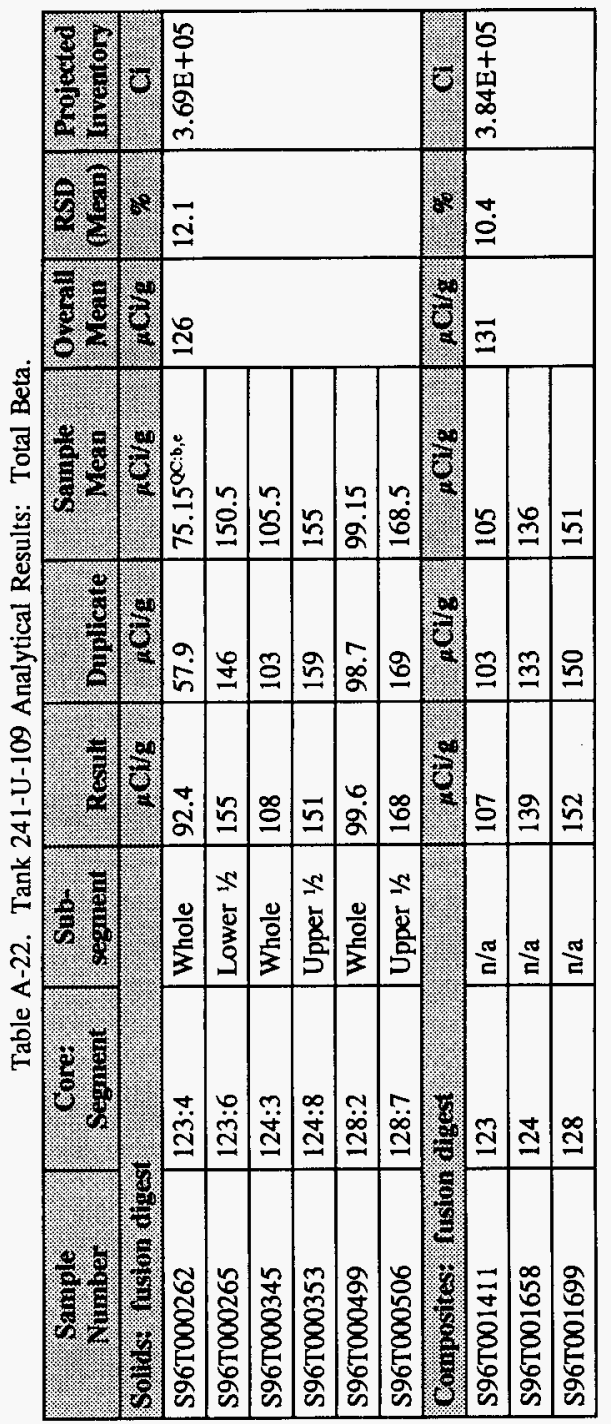


WHC-SD-WM-ER-609 Rev. 0

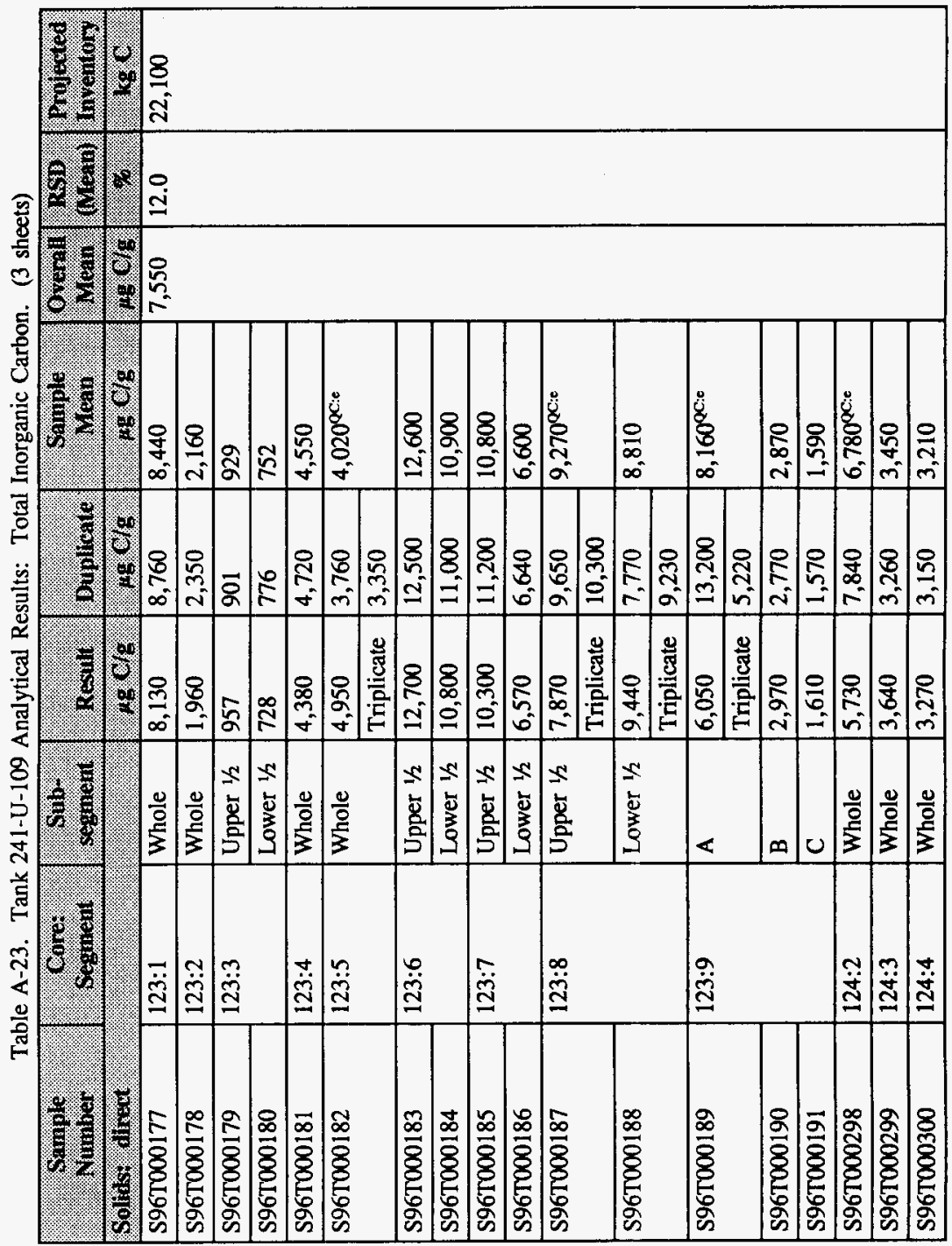


Table A-23. Tank 241-U-109 Analytical Results: Total Inorganic Carbon. (3 sheets)

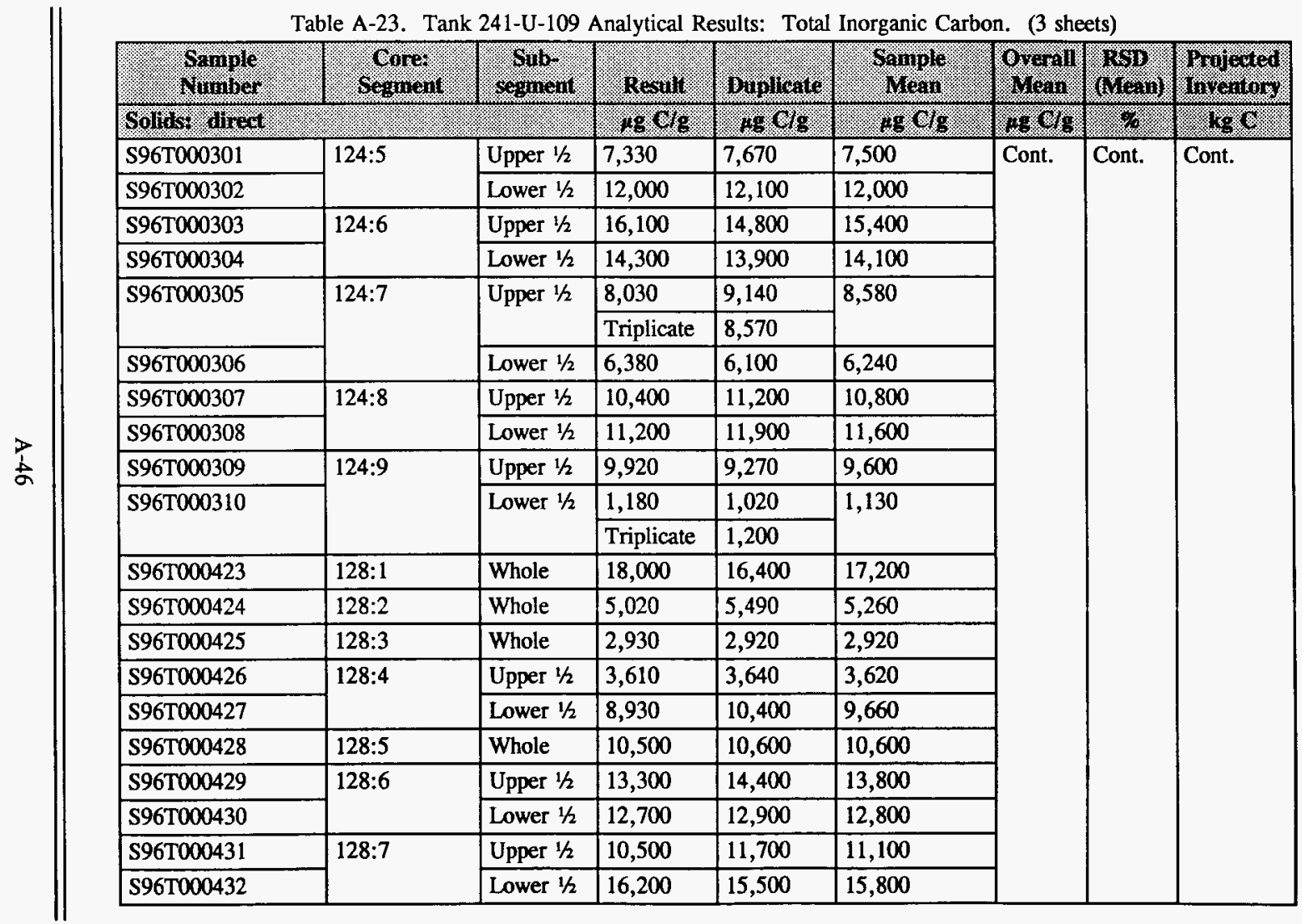




\begin{tabular}{|c|c|c|c|c|c|c|c|c|}
\hline \multirow[b]{8}{*}{$00 S^{6} 0 \mathrm{I}$} & \multirow[b]{8}{*}{$8 . L$} & \multirow[b]{8}{*}{$009^{\circ} \varepsilon$} & $001^{\prime} t$ & $0 \mathrm{II} t$ & $080^{\circ} t$ & $z / 1$ Iәмо & \multirow[b]{2}{*}{ 9:EZI } & t81000I96S \\
\hline & & & $09 L^{\prime} t$ & $0 \varepsilon 8^{\prime \prime}$ & $069^{\circ} t$ & $z / 1 \operatorname{Iadd} \Lambda$ & & E8I000I.96S \\
\hline & & & $08 t^{6} \tau$ & $O E E^{\prime} Z$ & $029^{\circ} \mathrm{Z}$ & әо०М & s:EZI & $281000 \mathrm{~L} 96 \mathrm{~S}$ \\
\hline & & & $0 z 0^{\circ} z$ & $0+00^{\prime} z$ & $000^{\circ} \mathrm{Z}$ & ગ०ЧМ & $t: \varepsilon Z I$ & $181000 \mathrm{~L} 96 \mathrm{~S}$ \\
\hline & & & $0 E I^{\prime} \mathrm{I}$ & OLI'I & $060^{\circ} \mathrm{I}$ & z/1 IOMOI & \multirow[b]{2}{*}{$\varepsilon: \varepsilon Z I$} & 081000.196S \\
\hline & & & $00 E^{6} I$ & OIE'I & $00 \varepsilon^{6} \mathrm{I}$ & $z / 1 \operatorname{Iadd} \Pi$ & & $6 L 1000 \mathrm{~L} 96 \mathrm{~S}$ \\
\hline & & & OSE' & $087^{\circ} z$ & $0 z z^{\prime} z$ & गО्पМ & $Z: \varepsilon Z I$ & $8 L 1000 \mathrm{~L} 96 \mathrm{~S}$ \\
\hline & & & $069^{\prime} z$ & $0 \varepsilon 9^{\circ} Z$ & $0 S L^{\prime} Z$ & ग०ЧМ & \multirow{2}{*}{$\frac{[: \varepsilon Z \mid]}{4}$} & LLIO00L96S \\
\hline . & 8 & 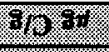 & 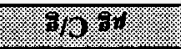 & ofo for & 8 . & 8 & & 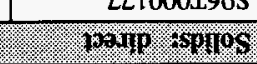 \\
\hline 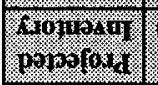 & 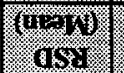 & 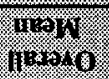 & uraht & omoritina & mpord & $\begin{array}{l}\text { wowars } \\
\text { quss }\end{array}$ & ? wawars & $\begin{array}{l}\text { Tiquino } \\
\text { jodnes }\end{array}$ \\
\hline & & 2045 t) $\cdot u$ & 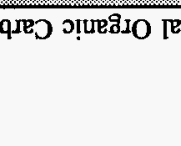 & 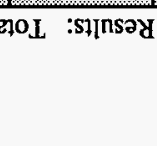 & [es! KГRuV & $-\Pi-I t z$ XL & $\diamond z-\forall$ ә૧૯ & \\
\hline \multirow[b]{3}{*}{$00 t^{i} \triangleright \tau$} & \multirow[b]{3}{*}{$8 . \mathrm{L}$} & \multirow[b]{3}{*}{$0+\varepsilon^{\prime} 8$} & $012^{\prime} 6$ & $059 \div 6$ & $0 L L^{\prime} 8$ & $\mathrm{e} / \mathrm{u}$ & $8 \mathrm{ZI}$ & $869100 \mathrm{~L} 96 \mathrm{~S}$ \\
\hline & & & $0 Z L^{\prime} 8$ & $025^{\prime} 8$ & $0 \varepsilon 6^{\prime} 8$ & $\mathrm{e} / \mathrm{u}$ & $\nabla Z I$ & LS9I00L96S \\
\hline & & & $060^{\circ} \mathrm{L}$ & $00 L^{\prime} L$ & $08 t^{\prime} 9$ & $\mathrm{e} / \mathrm{u}$ & $\varepsilon Z I$ & LODIO0L $96 \mathrm{~S}$ \\
\hline 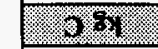 & 8 & $6 / 28$ & 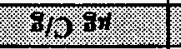 & ofor & $808 \%$ & 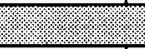 & & pourp solsodirop \\
\hline \multirow{4}{*}{ (3) } & & & $S \cdot+0 L$ & 899 & $I t L$ & әоОчМ & $6: 8 \mathrm{ZI}$ & SEt000LL66S \\
\hline & & & $00 t^{\prime} I I$ & $009^{\prime} \mathrm{II}$ & $00 \varepsilon^{\prime} I I$ & $z / 1$ LәMOT & \multirow[b]{2}{*}{$8: 8 \mathrm{ZI}$} & $\downarrow \mathcal{E} t 000 \mathrm{~L} 96 \mathrm{~S}$ \\
\hline & & & $02 t^{6} 6$ & $059^{4} 6$ & $06 I^{\prime} 6$ & $z_{1}$ ladd $\Omega$ & & EEt000L96S \\
\hline & 48. & $8 / 3.8 \%$ & 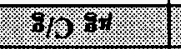 & $8 / 2$. In & 3.7 $3 \%$ & 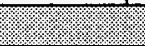 & \multicolumn{2}{|c|}{ 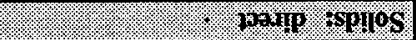 } \\
\hline 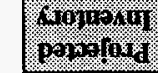 & mas & $\begin{array}{l}1000 \% \\
113020\end{array}$ & $\begin{array}{l}\text { mow } \\
\text { idines: }\end{array}$ & ojuginina & 11098 & Inomos:s & 1970moss & 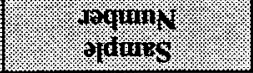 \\
\hline
\end{tabular}

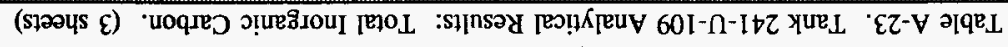


Table A-24. Tank 241-U-109 Analytical Results: Total Organic Carbon. (4 sheets)

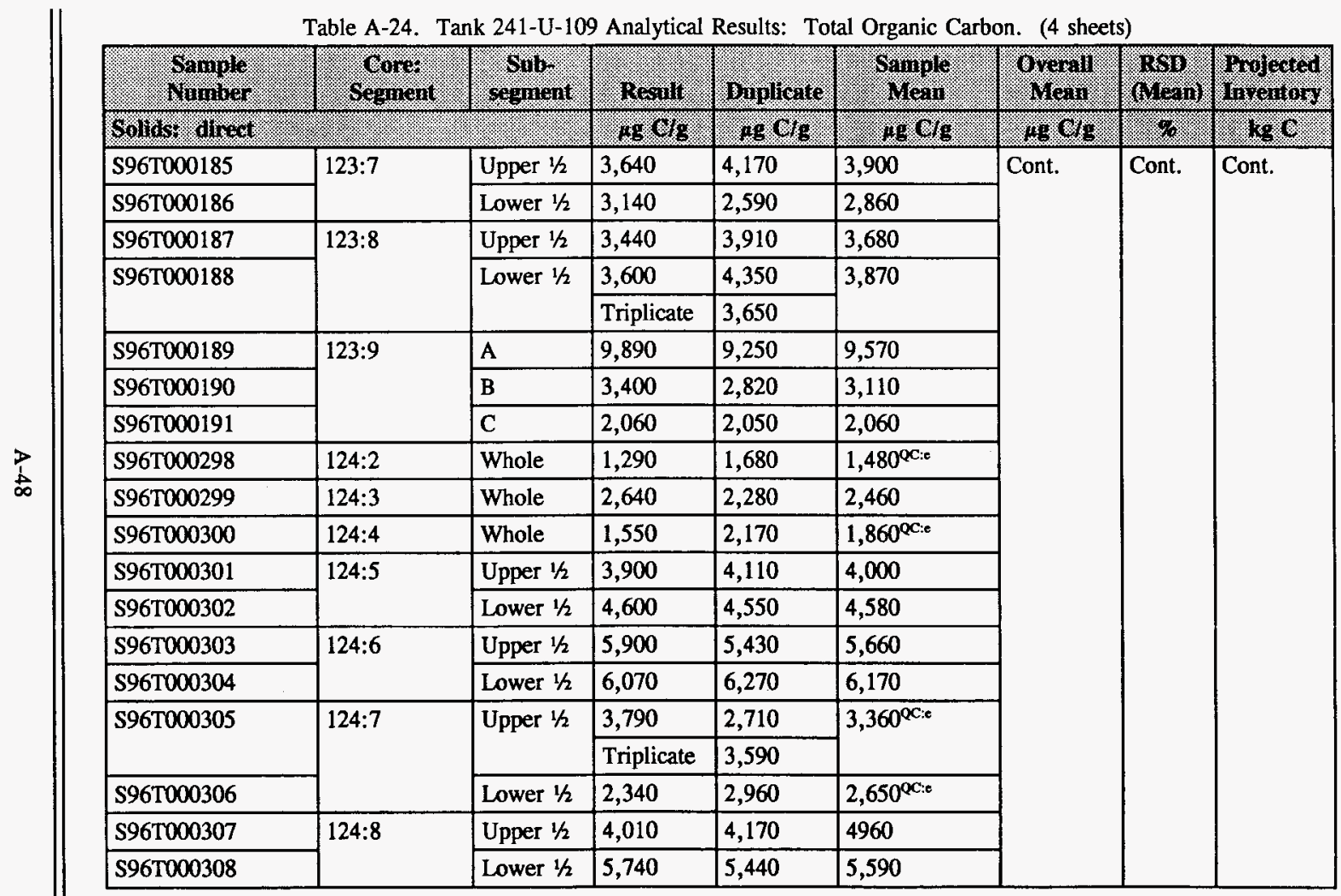


Table A-24. Tank 241-U-109 Analytical Results: Total Organic Carbon. (4 sheets)

\begin{tabular}{|c|c|c|c|c|c|c|c|c|}
\hline Sample & Sores & gons. & mitil & Orplicate & Mampla & Wyan & 16\% & 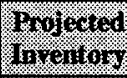 \\
\hline Solidst direot & (3) & (3. & 18.6 & of & 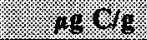 & 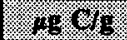 & 16. & . $6 \mathrm{~g}$. \\
\hline S96T000309 & \multirow[t]{2}{*}{$124: 9$} & Upper $1 / 2$ & 4,570 & 5,470 & 5,020 & \multirow[t]{11}{*}{ Cont. } & \multirow[t]{11}{*}{ Cont. } & \multirow[t]{11}{*}{ Cont. } \\
\hline S96T000310 & & Lower $1 / 2$ & 6,070 & 4,930 & $5,310^{\text {oc:c }}$ & & & \\
\hline S96T000424 & $128: 2$ & Whole & 2,500 & 2,670 & 2,580 & & & \\
\hline S96T000425 & $128: 3$ & Whole & 2,710 & 2,660 & 2,680 & & & \\
\hline S96T000426 & \multirow[t]{2}{*}{$128: 4$} & Upper $1 / 2$ & 2,680 & 2,610 & 2,640 & & & \\
\hline S96T000427 & & Lower $1 / 2$ & 6,820 & 5,900 & 6,360 & & & \\
\hline S96T000431 & \multirow[t]{2}{*}{$128: 7$} & Upper $1 / 2$ & 4,390 & 4,210 & $4,300^{\mathrm{QC:c}}$ & & & \\
\hline S96T000432 & & Lower $1 / 2$ & 5,740 & 5,790 & 5,760 & & & \\
\hline S96T000433 & \multirow[t]{2}{*}{$128: 8$} & Upper $1 / 2$ & 3,350 & 3,410 & 3,380 & & & \\
\hline S96T000434 & & Lower $1 / 2$ & 4,820 & 5,120 & 4,970 & & & \\
\hline S96T000435 & $128: 9$ & Whole & 3,850 & 3,510 & 3,680 & & & \\
\hline
\end{tabular}




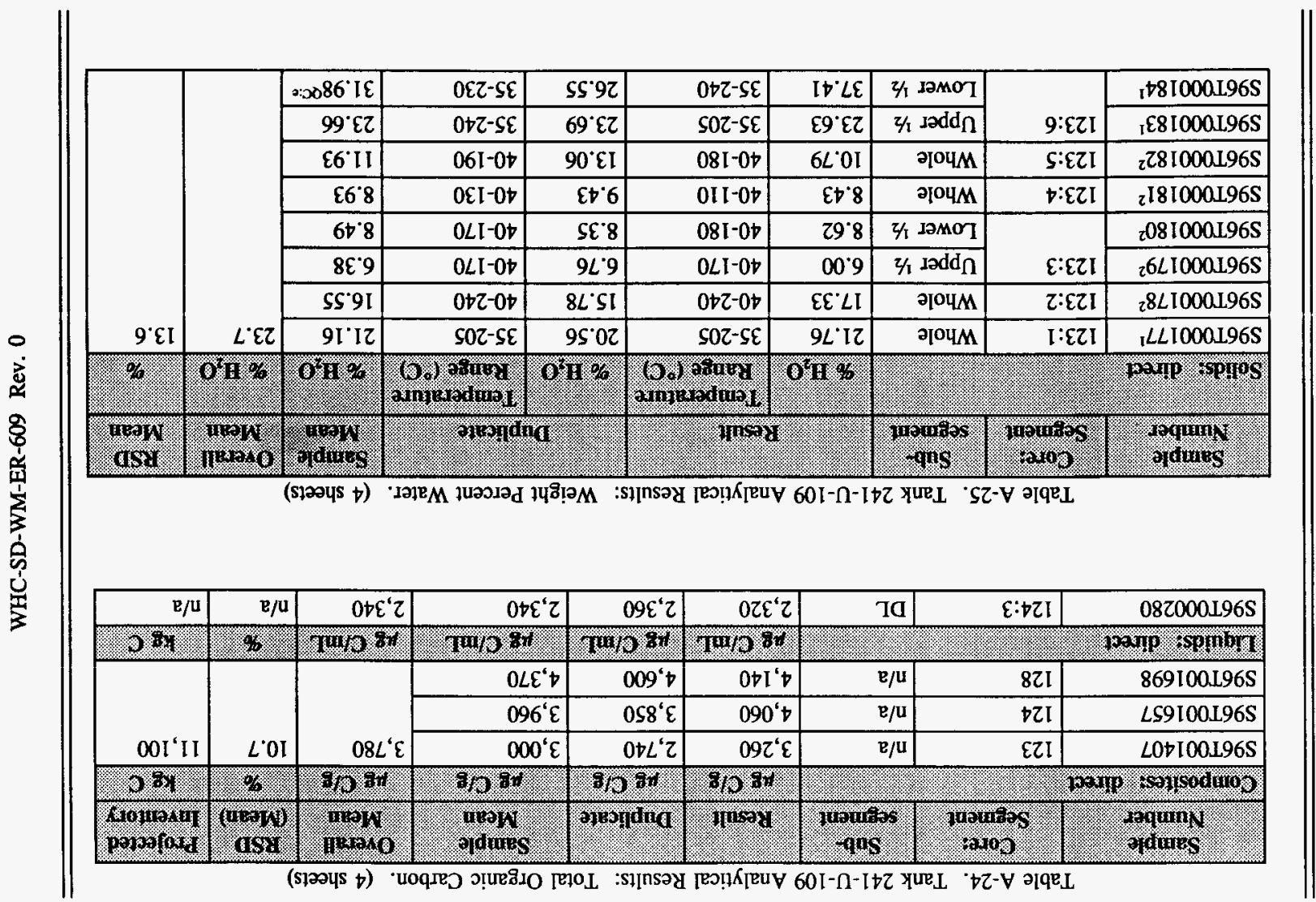


Table A-25. Tank 241-U-109 Analytical Results: Weight Percent Water. (4 sheets)

\begin{tabular}{|c|c|c|c|c|c|c|c|c|c|}
\hline $\begin{array}{l}\text { Sample. } \\
\text { Number }\end{array}$ & $\begin{array}{c}\text { Cores } \\
\text { Segarent }\end{array}$ & $\begin{array}{l}\text { Suti: } \\
\text { segminent }\end{array}$ & \multicolumn{2}{|c|}{ Resuly } & \multicolumn{2}{|c|}{ Buplinatc. } & \multirow{2}{*}{ 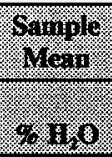 } & \multirow{2}{*}{ 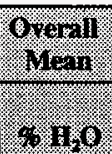 } & \multirow{2}{*}{$\begin{array}{l}\text { molo } \\
\text { Mean } \\
\end{array}$} \\
\hline Sollds: atred & (3: & & 28140 & $\begin{array}{l}\text { Temperaturs } \\
\text { range (oc) }\end{array}$ & $\%$ HO & $\begin{array}{l}\text { Temperamix } \\
\text { ringe ( }(\mathrm{C})\end{array}$ & & & \\
\hline S96T000185 & \multirow[t]{2}{*}{$123: 7$} & Upper $1 / 2$ & 19.84 & $40-170$ & 19.21 & $40-170$ & 19.52 & \multirow[t]{18}{*}{ Cont. } & \multirow[t]{18}{*}{ Cont. } \\
\hline S96T000186 ${ }^{2}$ & & Lower $1 / 2$ & 15.24 & $40-160$ & 20.01 & $40-170$ & 17.62 & & \\
\hline S96T000187 ${ }^{2}$ & \multirow[t]{2}{*}{$123: 8$} & Upper $1 / 2$ & 22.27 & $40-150$ & 24.96 & $40-160$ & 23.62 & & \\
\hline S96T000188 & & Lower $1 / 2$ & 17.54 & $40-155$ & 20.29 & $40-150$ & 18.91 & & \\
\hline S96T000189 & \multirow[t]{3}{*}{$123: 9$} & A & 37.02 & $40-130$ & 38.33 & $40-150$ & 37.67 & & \\
\hline S96T000190 & & B & 17.91 & $40-100$ & 23.86 & $40-160$ & 20.88 & & \\
\hline S96T000191 ${ }^{1}$ & & C & 17.38 & $35-180$ & 16.80 & $35-230$ & 17.09 & & \\
\hline S96T000298 & $124: 2$ & Whole & 15.85 & $35-200$ & 19.64 & $24-230$ & 17.75 & & \\
\hline S96T000299' & $124: 3$ & Whole & 42.89 & $35-250$ & 41.08 & $35-250$ & $41.98^{3}$ & & \\
\hline S96T000300 ${ }^{1}$ & $124: 4$ & Whole & 11.69 & $35-210$ & 10.33 & $35-180$ & 11.01 & & \\
\hline S96T000301 ${ }^{2}$ & \multirow[t]{2}{*}{$124: 5$} & Upper $1 / 2$ & 20.73 & $40-180$ & 24.35 & $40-180$ & 22.54 & & \\
\hline S96T000302 ${ }^{2}$ & & Lower $1 / 2$ & 19.66 & $40-180$ & 23.16 & $40-160$ & 21.41 & & \\
\hline S96T0003032 & \multirow[t]{2}{*}{$124: 6$} & Upper $1 / 2$ & 30.97 & $40-170$ & 26.65 & $40-170$ & 28.81 & & \\
\hline S96T000304 ${ }^{2}$ & & Lower $1 / 2$ & 36.39 & $40-170$ & 35.57 & $40-170$ & 35.98 & & \\
\hline S96T000305 ${ }^{2}$ & \multirow[t]{2}{*}{$124: 7$} & Upper $1 / 2$ & 15.78 & $40-170$ & 15.98 & $40-160$ & 15.88 & & \\
\hline S96T000306 2 & & Lower $1 / 2$ & 17.25 & $35-160$ & 20.84 & $40-160$ & 19.05 & & \\
\hline S96T000307 ${ }^{1}$ & \multirow[t]{2}{*}{$124: 8$} & Upper $1 / 2$ & 35.18 & $24-200$ & 34.01 & $35-240$ & 34.59 & & \\
\hline S96T000308 & & Lower $1 / 2$ & 34.90 & $40-200$ & 33.06 & $27-210$ & 33.98 & & \\
\hline
\end{tabular}




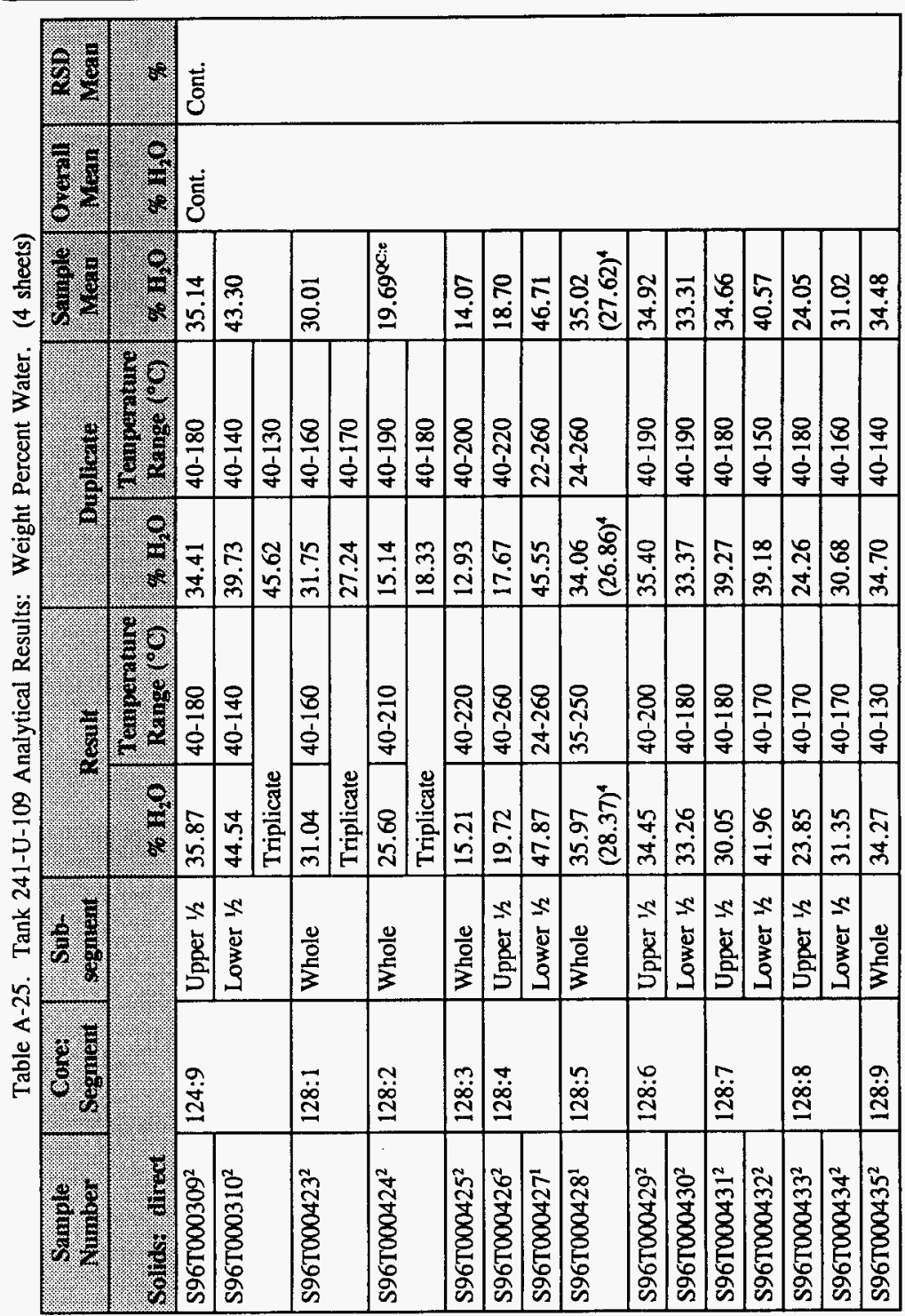


Table A-25. Tank 241-U-109 Analytical Results: Weight Percent Water. (4 sheets)

\begin{tabular}{|c|c|c|c|c|c|c|c|c|c|}
\hline $\begin{array}{l}\text { Sample } \\
\text { Number }\end{array}$ & Hegran & opin & \multicolumn{2}{|c|}{$\mathrm{res}=31$} & \multicolumn{2}{|c|}{ Buplie } & (Y) & W\%, & 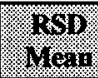 \\
\hline \multicolumn{3}{|c|}{ 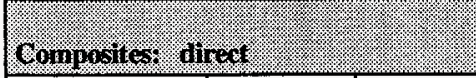 } & \% $10 \%$ & mang wror & c. 3. & 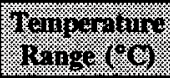 & 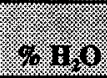 & 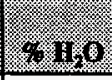 & . \\
\hline S96T0014072 & 123 & $\mathrm{n} / \mathrm{a}$ & 18.19 & $40-170$ & 21.53 & $40-160$ & 19.86 & \multirow[t]{3}{*}{25.3} & \multirow[t]{3}{*}{12.4} \\
\hline S96T0016572 & 124 & $\mathrm{n} / \mathrm{a}$ & 26.27 & $35-170$ & 24.46 & $35-180$ & 25.37 & & \\
\hline S96T0016982 & 128 & $\mathrm{n} / \mathrm{a}$ & 30.13 & $35-180$ & 31.23 & $35-200$ & 30.68 & & \\
\hline \multicolumn{3}{|c|}{ Brinible Tiquids dired } & 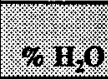 & 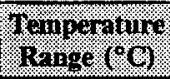 & 7. 110 & hompromor & (1) 810 & 4011,0 & 89 \\
\hline S96T0002802 & $124: 3$ & $\mathrm{DL}$ & 53.37 & $40-190$ & 53.03 & $40-190$ & 53.20 & $n / a$ & $n / a$ \\
\hline
\end{tabular}

Notes:

${ }^{1}$ Analysis performed on Perkin-Elmer ${ }^{\mathrm{TM}}$ equipment.

${ }^{2}$ Analysis performed on Mettler ${ }^{\mathrm{TM}}$ equipment.

${ }^{3}$ Due to HHF contamination, the results from this segment were not used in the mean, RSD (mean), or inventory calculations.

The data are presented for informational purposes only.

This sample showed a low level of HHF contamination. The corrected weight percent water results are given in parentheses (27.62\%), and

these values were utilized in the mean, RSD (mean), and inventory calculations. 
Table A-26. Tank 241-U-109 Analytical Results: Energetics by DSC. (5 sheets)

\begin{tabular}{|c|c|c|c|c|c|c|c|c|c|c|}
\hline \multirow{2}{*}{$\begin{array}{l}\text { Samples } \\
\text { Number } \\
\text { Solios allew }\end{array}$} & \multirow{2}{*}{ Segrient } & \multirow{2}{*}{$\frac{\text { Sub }}{\text { segrnerin }}$} & \multirow[t]{2}{*}{ Rruin } & \multirow{2}{*}{$\begin{array}{l}\text { Sample } \\
\text { Weight } \\
\\
\end{array}$} & \multicolumn{2}{|c|}{ Transition 1} & \multicolumn{2}{|c|}{ Transition 2} & \multicolumn{2}{|c|}{ Thansition 3} \\
\hline & & & & & $\begin{array}{l}\text { Iral } \\
\text { reno. } \\
180\end{array}$ & $\begin{array}{l}411 \\
108\end{array}$ & 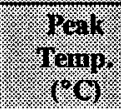 & $\frac{411}{810}$ & $\begin{array}{l}\text { ival } \\
\text { remp. } \\
\text { (a) }\end{array}$ & $\frac{\Delta n}{(1 / 1)}$ \\
\hline \multirow[t]{2}{*}{ S96T000177 } & \multirow[t]{2}{*}{ 123:1 } & \multirow[t]{2}{*}{ Whole } & 1 & 32.05 & 132.0 & 905.5 & 279.2 & 70.34 & --- & -- \\
\hline & & & 2 & 48.71 & 143.3 & 375.9 & --- & --- & --- & --- \\
\hline \multirow[t]{2}{*}{ S96T000178 ${ }^{2}$} & \multirow[t]{2}{*}{$123: 2$} & \multirow[t]{2}{*}{ Whole } & 1 & 45.05 & 144.7 & 455.8 & 283.5 & 59.0 & $-\cdots$ & $-\cdots$ \\
\hline & & & 2 & 49.95 & 143.8 & 317.8 & 283.8 & 73.0 & $\cdots$ & -- \\
\hline \multirow[t]{2}{*}{ S96T000179² } & \multirow[t]{4}{*}{$123: 3$} & \multirow[t]{2}{*}{ Upper $1 / 2$} & 1 & 35.07 & 126.1 & 161.1 & 201.3 & 0.8 & 291.9 & 160.3 \\
\hline & & & 2 & 35.30 & 115.1 & 91.8 & 198.0 & 4.1 & 288.9 & 121.0 \\
\hline \multirow[t]{2}{*}{ S96T0001802 } & & \multirow[t]{2}{*}{ Lower $1 / 2$} & 1 & 40.00 & 121.5 & 134.1 & 196.9 & 1.0 & 296.7 & 176.5 \\
\hline & & & 2 & 22.68 & 106.5 & 300.3 & 197.4 & 2.3 & 298.4 & 179.7 \\
\hline \multirow[t]{2}{*}{ S96T000181 12,3} & \multirow[t]{2}{*}{$123: 4$} & \multirow[t]{2}{*}{ Whole } & 1 & 18.81 & 121.3 & 201.1 & 287.5 & 160.3 & 338.5 & 6.3 \\
\hline & & & 2 & 26.86 & 116.4 & 192.2 & 191.7 & 9.7 & 288.8 & 140.7 \\
\hline \multirow[t]{2}{*}{ S96T000182 2,4 } & \multirow[t]{2}{*}{$123: 5$} & \multirow[t]{2}{*}{ Whole } & 1 & 24.54 & 128.6 & 223.3 & 275.1 & 166.7 & 364.5 & 2.8 \\
\hline & & & 2 & 38.43 & 139.5 & 273.5 & 276.6 & 98.4 & 326.2 & 2.5 \\
\hline \multirow[t]{3}{*}{ S96T0001842 } & \multirow[t]{3}{*}{$123: 6$} & \multirow[t]{3}{*}{ Lower $1 / 2$} & 1 & 43.86 & 145.8 & 519.5 & 242.3 & -68.7 & -- & -- \\
\hline & & & 2 & 42.66 & 149.5 & 547.5 & 240.0 & -9.8 & 350.0 & \begin{tabular}{|l|}
-78.7 \\
\end{tabular} \\
\hline & & & 3 & 53.19 & 139.3 & 407.5 & 341.9 & -52.9 & $-\cdots$ & $\ldots$ \\
\hline \multirow[t]{2}{*}{ S96T000186 ${ }^{2}$} & \multirow[t]{2}{*}{$123: 7$} & \multirow[t]{2}{*}{ Lower $1 / 2$} & 1 & 24.52 & 110.8 & 476.8 & 284.5 & 94.6 & $\ldots$ & -- \\
\hline & & & 2 & 19.62 & 103.0 & 458.1 & 272.7 & 104.7 & --. & $\ldots$ \\
\hline
\end{tabular}


Table A-26. Tank 241-U-109 Analytical Results: Energetics by DSC. (5 sheets)

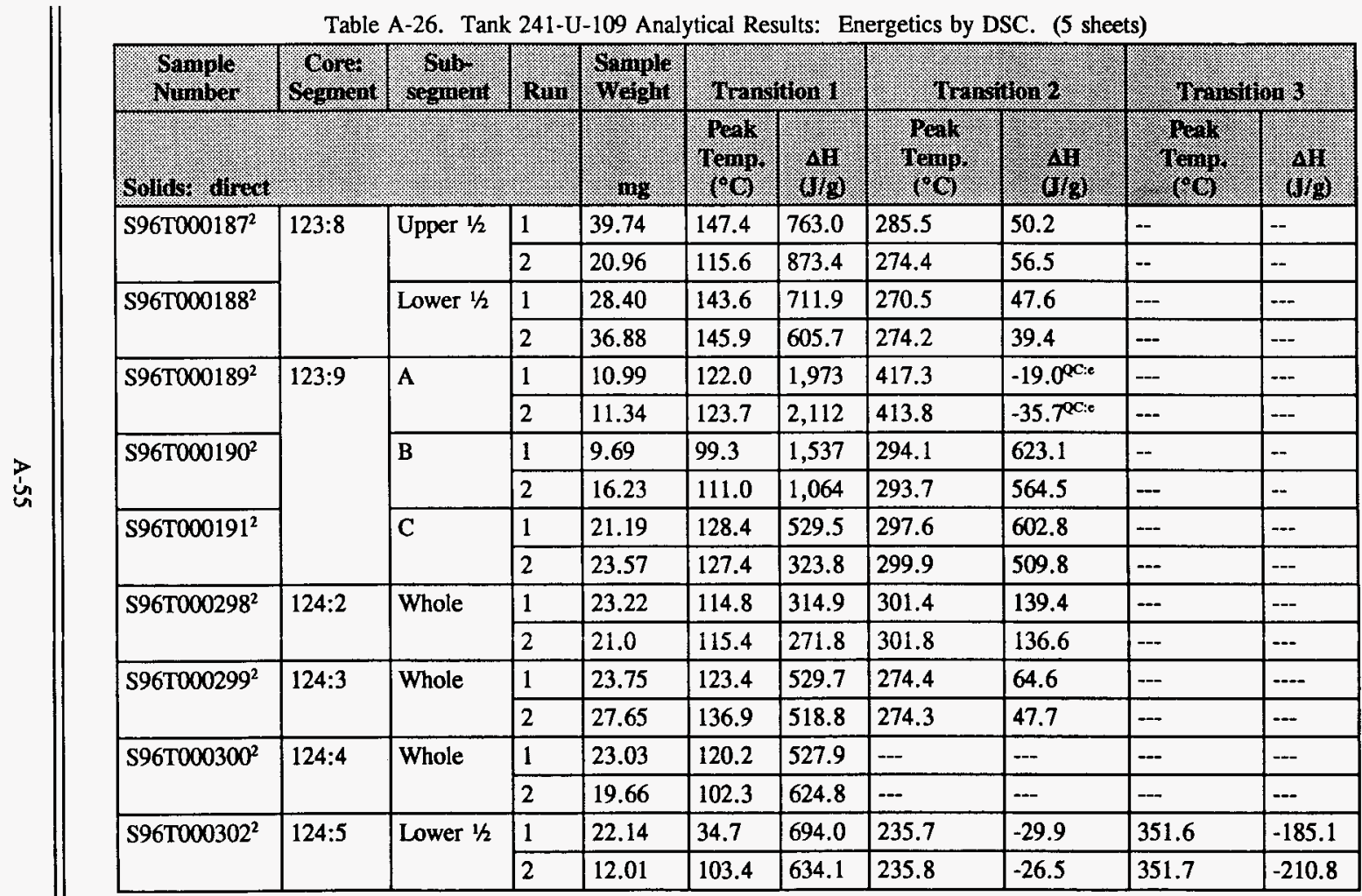


Table A-26. Tank 241-U-109 Analytical Results: Energetics by DSC. (5 sheets)

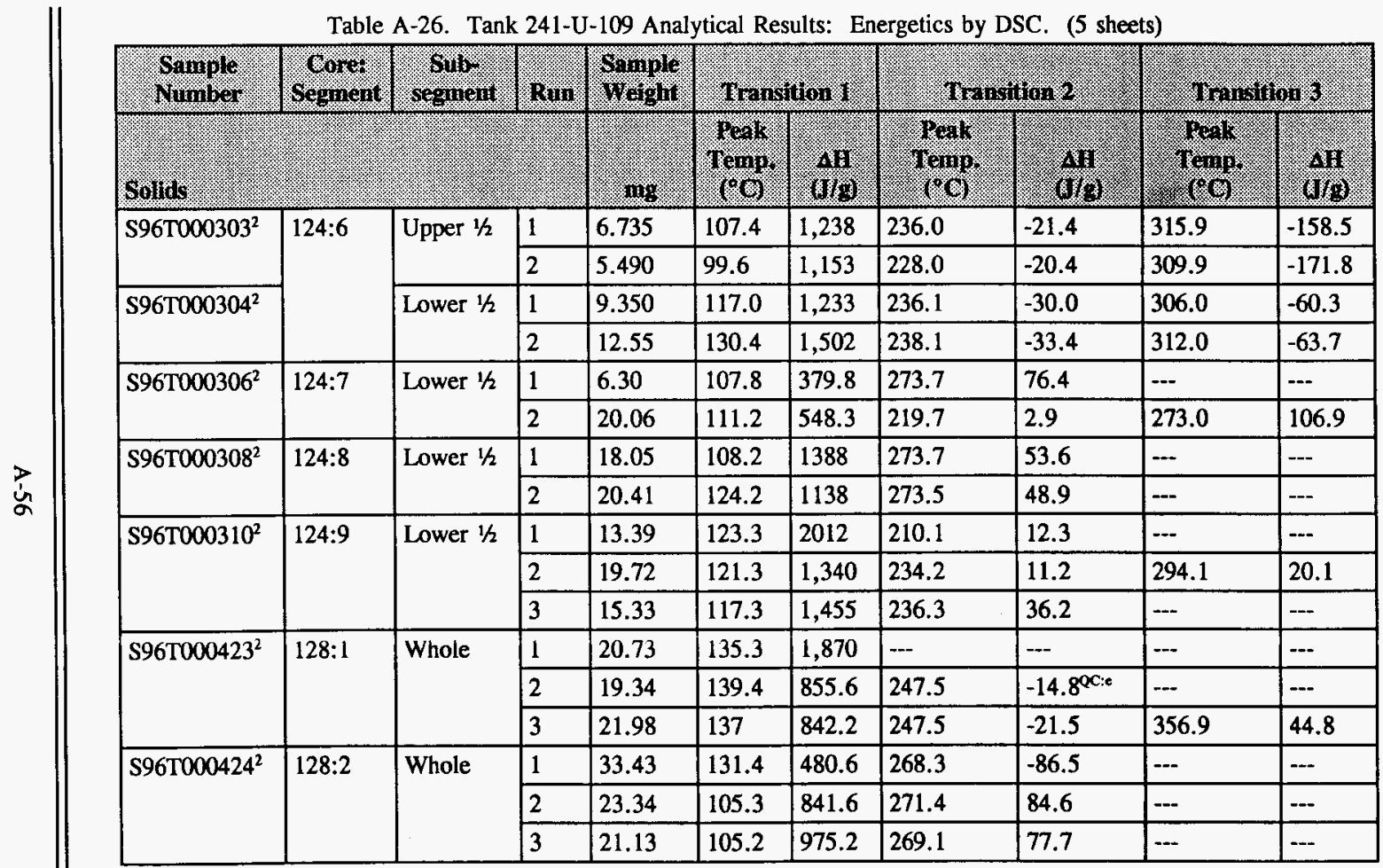


Table A-26. Tank 241-U-109 Analytical Results: Energetics by DSC. (5 sheets)

\begin{tabular}{|c|c|c|c|c|c|c|c|c|c|c|}
\hline \multirow[t]{2}{*}{$\begin{array}{l}\text { Samples } \\
\text { Sumber }\end{array}$} & \multirow{2}{*}{ Gegment } & \multirow{2}{*}{ segunentil } & \multirow[t]{2}{*}{ Ron } & \multirow{2}{*}{$\begin{array}{l}\text { Sample } \\
\text { Weight } \\
\text { mag: }\end{array}$} & \multicolumn{2}{|c|}{ Transition I } & \multicolumn{2}{|c|}{ Transition ? } & \multicolumn{2}{|c|}{ Transinion 3} \\
\hline & & & & & $\begin{array}{l}\text { Ters } \\
\text { remp. } \\
(96)\end{array}$ & ur & $\begin{array}{l}\text { Perl } \\
\text { Terrip } \\
(180)\end{array}$ & $\frac{\Delta 11}{048}$ & 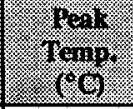 & $\begin{array}{l}411 \\
(119)\end{array}$ \\
\hline \multirow[t]{2}{*}{ S96T000425 } & \multirow[t]{2}{*}{$128: 3$} & \multirow[t]{2}{*}{ Whole } & 1 & 42.08 & 139.3 & 788.1 & $-\cdots$ & $-\cdots$ & -- & -- \\
\hline & & & 2 & 78.30 & 141.3 & 611.1 & -- & $\ldots$ & -- & -- \\
\hline \multirow[t]{2}{*}{ S96T000426 } & \multirow[t]{4}{*}{$128: 4$} & \multirow[t]{2}{*}{ Upper $1 / 2$} & 1 & 21.40 & 141.9 & 556.7 & 268.5 & 60.8 & $-\cdots$ & -- \\
\hline & & & 2 & 42.05 & 138.5 & 646.7 & 274.9 & 96.4 & -- & -- \\
\hline \multirow[t]{2}{*}{ S96T000427 } & & \multirow[t]{2}{*}{ Lower $1 / 2$} & 1 & 27.91 & 131.3 & 1,599 & 324.4 & $-142.6^{\mathrm{OC}: e}$ & & \\
\hline & & & 2 & 26.46 & 133.3 & 1,539 & 246.0 & $-97.3^{\mathrm{QC}: \mathrm{e}}$ & -- & $-\cdots$ \\
\hline \multirow[t]{2}{*}{ S96T000428 } & \multirow[t]{2}{*}{$128: 5$} & \multirow[t]{2}{*}{ Whole } & 1 & 22.81 & 114.5 & 1,356 & 239.7 & $-8.9^{9 \mathrm{C}: \mathrm{e}}$ & $\ldots$ & -- \\
\hline & & & 2 & 25.23 & 145.8 & 1,346 & \begin{tabular}{|l|}
243.8 \\
\end{tabular} & $-13.8^{\mathrm{QC}: e}$ & $\cdots$ & -- \\
\hline \multirow[t]{2}{*}{ S96T0004302 } & \multirow[t]{2}{*}{$128: 6$} & \multirow[t]{2}{*}{ Lower $1 / 2$} & 1 & 12.17 & 122.5 & 1,210 & \begin{tabular}{|l|}
236.2 \\
\end{tabular} & -25.1 & 302.1 & -49.2 \\
\hline & & & 2 & 17.85 & 123.8 & 1,519 & 238.2 & -26.7 & 308.1 & -50.7 \\
\hline \multirow[t]{2}{*}{ S96T000432² } & \multirow[t]{2}{*}{$128: 7$} & \multirow[t]{2}{*}{ Lower $1 / 2$} & 1 & 19.57 & 121.8 & 1,117 & 226.2 & -33.1 & 310.0 & -44.8 \\
\hline & & & 2 & 10.85 & 122.6 & 1,302 & 234.2 & -28.2 & 300.1 & -51.7 \\
\hline \multirow[t]{3}{*}{ S96T000434² } & \multirow[t]{3}{*}{$128: 8$} & \multirow[t]{3}{*}{ Lower $1 / 2$} & 1 & 5.630 & 34.6 & 1,549 & \begin{tabular}{|l|}
271.8 \\
\end{tabular} & 76.4 & $-\cdots$ & --- \\
\hline & & & 2 & 8.232 & 105.4 & 1,146 & 228.1 & -4.9 & 326.0 & -72.5 \\
\hline & & & 3 & 8.820 & 107.0 & 1,206 & 226.2 & -8.7 & 308.1 & -39.8 \\
\hline \multirow[t]{2}{*}{ S96T000435 } & \multirow[t]{2}{*}{ 128:9 } & \multirow[t]{2}{*}{ Whole } & 1 & 27.34 & 115.3 & 972.6 & 297.6 & 182.1 & -- & --- \\
\hline & & & 2 & 14.11 & 131.6 & 804.2 & 304.7 & 144.8 & --- & $\cdots$ \\
\hline
\end{tabular}




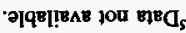

$8 / \mathrm{C} L \cdot \dagger Z$ J0 HV

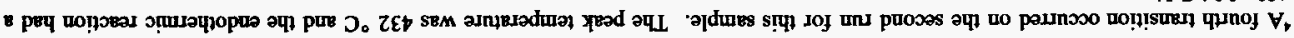

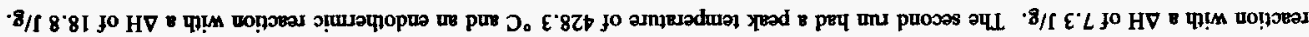
эпщuәq)

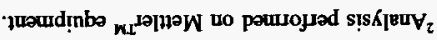

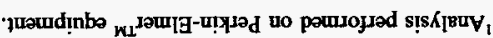

\begin{tabular}{|c|c|c|c|c|c|c|c|c|c|c|}
\hline 728 & 5062 & $b^{\circ} I 2$ & $0^{\circ} \varepsilon \neq Z$ & $200^{\prime} 1$ & I'80I & 19.91 & $\tau$ & \multirow[b]{2}{*}{$\mathrm{T} ם$} & \multirow[b]{2}{*}{$\varepsilon: \triangleright Z I$} & \multirow[b]{2}{*}{${ }_{2082000 L 96 S}$} \\
\hline $0.9 \mathfrak{E Z}$ & 0.162 & $0 \div I$ & $\nabla^{\circ} \varepsilon \neq Z$ & $\nabla 6 L 8$ & $8^{\circ}+2 I$ & $\nabla I^{\circ} S I$ & $I$ & & & \\
\hline ely & $\frac{6}{64}$ & 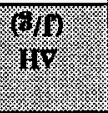 & 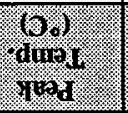 & (1) & 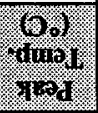 & काin: & & & & 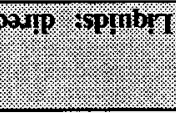 \\
\hline & & & & & & & $z$ & \multirow[b]{2}{*}{$\mathrm{E} / \mathrm{u}$} & \multirow[b]{2}{*}{$82 I$} & \multirow[b]{2}{*}{ s'z869I00L96S } \\
\hline & & & & & & & $\mathrm{I}$ & & & \\
\hline & & & & & & & 2 & \multirow[b]{2}{*}{$\mathrm{E} / \mathrm{u}$} & \multirow[b]{2}{*}{$\nabla Z I$} & \multirow[b]{2}{*}{${ }^{\star} z L 59 I 00 L 96 \mathrm{~S}$} \\
\hline & & & & & & & I & & & \\
\hline $6 \mathrm{SI}^{-}$ & $\tau^{\circ} \mathcal{E} 6 \varepsilon$ & $6.0 \varepsilon$ & 6.882 & 5.889 & $8^{\circ}$ IEI & $z Z \angle Z$ & $z$ & \multirow[b]{2}{*}{$\mathrm{e} / \mathrm{u}$} & \multirow[b]{2}{*}{$\varepsilon Z I$} & \multirow[b]{2}{*}{${ }_{z} L 0+100 L 96 S$} \\
\hline$I^{\circ} \mathcal{E} I^{-}$ & $9^{\circ} \mathrm{S} 6 \mathcal{E}$ & $8: \angle S$ & $\mathrm{I}^{\prime} \mathrm{S} 8 \mathrm{Z}$ & $I^{\circ} 6 \angle 9$ & $S+I I$ & $87^{\circ} \varsigma Z$ & I & & & \\
\hline$(8)$ & $(6)$ & 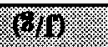 & $(8.6)$ & OF & $(x)$ & $8 \%$ & & & \multirow[t]{2}{*}{ 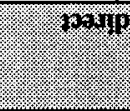 } & \multirow[t]{2}{*}{18.99159010} \\
\hline ilv & 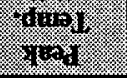 & $y_{1} y^{2}$ & 91101 & iv & $\begin{array}{l}\text { 1110\% } \\
115 \%\end{array}$ & & & & & \\
\hline & 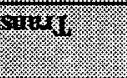 & \multicolumn{2}{|c|}{ 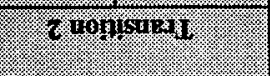 } & \multicolumn{2}{|c|}{ 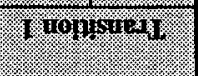 } & $10 \% 4$ & iny & $19110 \%$ & homos & (5) \\
\hline
\end{tabular}

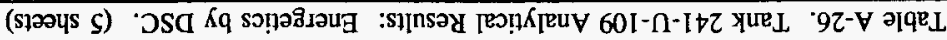


Table A-27. Tank 241-U-109 Analytical Results: Bulk Density/Specific Gravity. (3 sheets)

\begin{tabular}{|c|c|c|c|c|c|c|c|}
\hline K. & . Gever & scensentir & thenil & Bupligate & Golph & $x_{1,4}$ & 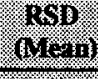 \\
\hline Sollors olirect & (3. & & 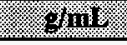 & ginl: & gring & grint & \% \\
\hline S96T000207 & 123:1 & Whole & 1.85 & $\mathrm{n} / \mathrm{a}$ & 1.85 & \multirow[t]{21}{*}{1.67} & \multirow[t]{21}{*}{1.6} \\
\hline S96T000208 & $123: 2$ & Whole & 1.81 & $n / a$ & 1.81 & & \\
\hline S96T000209 & \multirow[t]{2}{*}{$123: 3$} & Upper $1 / 2$ & 1.24 & $n / a$ & 1.24 & & \\
\hline S96T000210 & & Lower $1 / 2$ & 1.30 & $n / a$ & 1.30 & & \\
\hline S96T000211 & $123: 4$ & \begin{tabular}{|l|} 
Whole \\
\end{tabular} & 1.67 & $\mathrm{n} / \mathrm{a}$ & 1.67 & & \\
\hline \$96T000212 & $123: 5$ & Whole & 1.59 & $n / a$ & 1.59 & & \\
\hline \$96T000213 & \multirow[t]{2}{*}{$123: 6$} & Upper $1 / 2$ & 1.68 & $\mathrm{n} / \mathrm{a}$ & 1.68 & & \\
\hline S96T000172 & & Lower $1 / 2$ & 1.75 & $\mathrm{n} / \mathrm{a}$ & 1.75 & & \\
\hline S96T000214 & \multirow[t]{2}{*}{$123: 7$} & Upper $1 / 2$ & 1.82 & $n / a$ & 1.82 & & \\
\hline S96T000173 & & Lower $1 / 2$ & 1.87 & $\mathrm{n} / \mathrm{a}$ & 1.87 & & \\
\hline \$96T000215 & \multirow[t]{2}{*}{$123: 8$} & Upper $1 / 2$ & 1.82 & $n / a$ & 1.82 & & \\
\hline S96T000174 & & Lower $1 / 2$ & 1.84 & $n / a$ & 1.84 & & \\
\hline S96T000216 & \multirow[t]{3}{*}{$123: 9$} & A & 1.42 & $n / a$ & 1.42 & & \\
\hline S967000175 & & B & - & $n / a$ & $--^{1}$ & & \\
\hline S96T000176 & & $\mathrm{C}$ & 1.97 & $n / a$ & 1.97 & & \\
\hline \$96T000282 & $124: 3$ & Whole & 1.66 & $n / a$ & 1.66 & & \\
\hline S96T000283 & $124: 4$ & Whole & 1.62 & $n / a$ & 1.62 & & \\
\hline S96T000284 & \multirow[t]{2}{*}{$124: 5$} & Upper $1 / 2$ & 1.73 & $n / a$ & 1.73 & & \\
\hline S96T000285 & & Lower $1 / 2$ & 1.72 & $n / a$ & 1.72 & & \\
\hline S96T000286 & \multirow[t]{2}{*}{$124: 6$} & Upper $1 / 2$ & 1.68 & $n / a$ & 1.68 & & \\
\hline S96T000287 & & Lower $1 / 2$ & 1.66 & $n / a$ & 1.66 & & \\
\hline
\end{tabular}


WHC-SD-WM-ER-609 Rev. 0

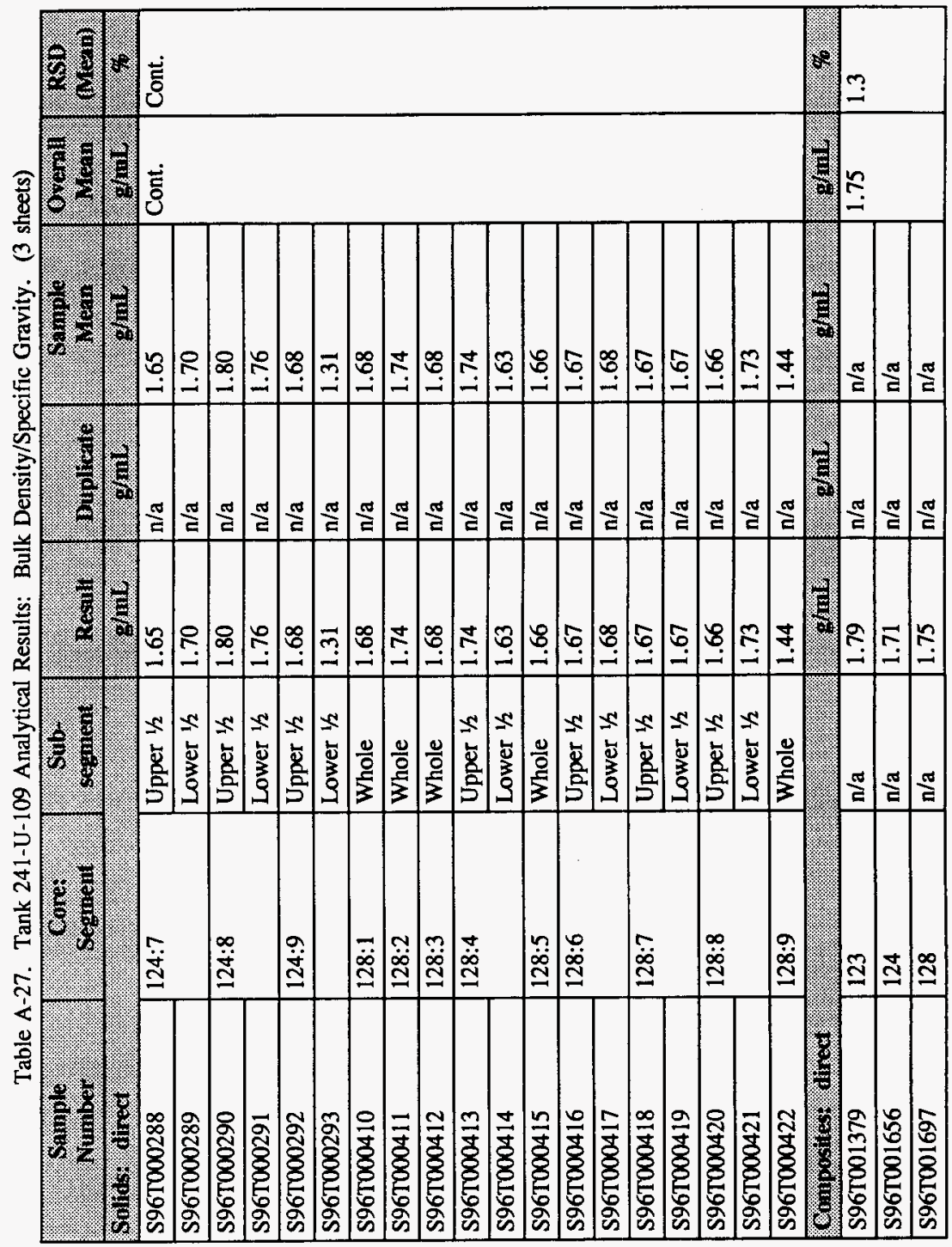


Table A-27. Tank 241-U-109 Analytical Results: Bulk Density/Specific Gravity. (3 sheets)

\begin{tabular}{|c|c|c|c|c|c|c|c|}
\hline $\begin{array}{l}\text { Ganple } \\
\text { Nouriber }\end{array}$ & \% & setingin: & Mesilit & Bupliate & onger & (x) & $\begin{array}{l}\text { RS1 } \\
(1+2.13)\end{array}$ \\
\hline Wruiks riledt & & & $9 / \mathrm{mil}$ & ginl & 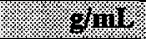 & 24 in & 18 \\
\hline S96T000280 & $124: 3$ & DL & 1.397 & 1.398 & 1.397 & $n / a$ & $n / a$ \\
\hline
\end{tabular}

Note:

${ }^{1}$ The laboratory did not report any results for this subsegment. 
WHC-SD-WM-ER-609 Rev. 0

This page intentionally left blank. 
WHC-SD-WM-ER-609 Rev. 0

APPENDIX B

ANALYTICAL RESULTS OF HYDROSTATIC HEAD FLUID

CONTAMINATION CHECK FOR SINGLE-SHELL TANK 241-U-109 
WHC-SD-WM-ER-609 Rev. 0

This page intentionally left blank. 


\section{B.0 ANALYTICAL RESULTS OF HYDROSTATIC HEAD FLUID CONTAMINATION CHECK FOR TANK 241-U-109}

\section{B.1 INTRODUCTION AND ANALYTE TABLE DESCRIPTION}

Appendix B reports the results of the HHF contamination check for the 1995/1996 push-mode core sampling and analysis event. Lithium and bromide were measured to detect any contamination of the waste samples by the HHF. For a description of the sampling event and information on sampling rationale and locations, see Section 3.0. A more detailed description of the HHF results is presented in Section 4.1.4.

Column one lists the laboratory sample identification number for which each of the two analytes was measured.

Column two specifies the core and segment from which each sample was derived.

Column three specifies the subsegment for which the analyte was measured. If adequate sample was available, the waste from a given segment was split into upper and lower halves, or divided into "quarter" segments (A, B, and C). If inadequate material was recovered to split the segment, it was analyzed as a "whole" segment. The single liquid result is identified as "DL".

The "Result" and "Duplicate" columns are self-explanatory. All values below the detection level (i.e., "nondetected") are indicated by the less than symbol, <. The "Sample Mean" column is the average of the result and duplicate values. If the result and duplicate values were both nondetected or detected, then the mean is expressed as a nondetected or detected value, respectively. The result and duplicate values, as well as the result/duplicate means, are reported in the tables exactly as found in the original laboratory data package. The means may appear to have been rounded up in some cases and rounded down in others. This is because the analytical results given in the tables may have fewer significant figures than originally reported, not because the means were incorrectly calculated.

Overall means, RSDs (mean), and projected inventories were not calculated for these two analytes because they are not inherent constituents of the tank waste.

The four QC parameters assessed on the tank 241-U-109 HHF samples were standard recoveries, spike recoveries, duplicate analyses (RPDs), and blanks. Only bromide had any QC results outside the parameters specified in the SAP (Baldwin 1996b). Two samples had low spike recoveries, and these are identified in the sample mean column of Table B-1 with a superscripted "QC:c". 
WHC-SD-WM-ER-609 Rev. 0

Table B-1. Tank 241-U-109 Analytical Results: Bromide. (2 sheets)

\begin{tabular}{|c|c|c|c|c|c|}
\hline 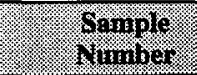 & 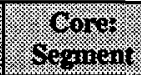 & S. & hrovil & $\begin{array}{l}3 \\
301\end{array}$ & 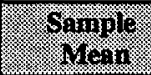 \\
\hline Solvop & \% & ;) & 86 & 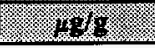 & 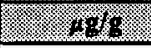 \\
\hline S96T000229 & 123:1 & Whole & $<1,180$ & $<1,290$ & $<1,240$ \\
\hline S96T000230 & $123: 2$ & Whole & $<1,050$ & $<1,150$ & $<1,100$ \\
\hline S96T000231 & \multirow[t]{2}{*}{$123: 3$} & Upper $1 / 2$ & $<980$ & $<1,000$ & $<990$ \\
\hline S96T000232 & & Lower $1 / 2$ & $<1,020$ & $<1,020$ & $<1,020$ \\
\hline S96T000233 & $123: 4$ & Whole & $<1,490$ & $<1,560$ & $<1,530$ \\
\hline S96T000234 & $123: 5$ & Whole & $<1,480$ & $<1,480$ & $<1,480$ \\
\hline S96T000235 & \multirow[t]{2}{*}{$123: 6$} & Upper $1 / 2$ & $<2,920$ & $<2,780$ & $<2,850$ \\
\hline S96T000236 & & Lower $1 / 2$ & $<2,270$ & $<2,190$ & $<2,230$ \\
\hline S96T000237 & \multirow[t]{2}{*}{$123: 7$} & Upper 1/2 & $<1,300$ & $<1,290$ & $<1,300$ \\
\hline S96T000238 & & Lower $1 / 2$ & $<1,390$ & $<1,420$ & $<1,410$ \\
\hline S96T000239 & \multirow[t]{2}{*}{$123: 8$} & Upper $1 / 2$ & $<1,030$ & $<1,010$ & $<1,020$ \\
\hline S96T000240 & & Lower $1 / 2$ & $<1,040$ & $<984$ & $<1,010$ \\
\hline S96T000241 & \multirow[t]{3}{*}{$123: 9$} & A & $<494$ & $<499$ & $<497$ \\
\hline S96T000242 & & B & $<142$ & $<139$ & $<141$ \\
\hline S96T000243 & & $\mathrm{C}$ & $<244$ & $<258$ & $<251$ \\
\hline S96T000357 & $124: 2$ & Whole & $<2,750$ & $<2,690$ & $<2,720^{\mathrm{QC}: \mathrm{c}}$ \\
\hline \$96T000358 & $124: 3$ & Whole & 6,110 & 6,570 & $6,340^{\mathrm{Qc}: c}$ \\
\hline S96T000359 & $124: 4$ & Whole & $<2,230$ & $<2,370$ & $<2,300$ \\
\hline$\$ 96 \mathrm{~T} 000360$ & \multirow[t]{2}{*}{$124: 5$} & Upper $1 / 2$ & $<1,310$ & $<1,200$ & $<1,260$ \\
\hline S96T000361 & & Lower $1 / 2$ & $<922$ & $<990$ & $<956$ \\
\hline S96T000362 & \multirow[t]{2}{*}{$124: 6$} & Upper $1 / 2$ & $<485$ & $<491$ & $<488$ \\
\hline S96T000363 & & Lower $1 / 2$ & $<510$ & $<482$ & $<496$ \\
\hline S96T000364 & \multirow[t]{2}{*}{$124: 7$} & Upper $1 / 2$ & $<1,150$ & $<1,280$ & $<1,220$ \\
\hline \$96T000365 & & Lower $1 / 2$ & $<2,840$ & $<1,330$ & $<2,090$ \\
\hline \$96T000366 & \multirow[t]{2}{*}{$124: 8$} & Upper $1 / 2$ & $<956$ & $<946$ & $<951$ \\
\hline$\$ 96 \mathrm{~T} 000367$ & & Lower $1 / 2$ & $<1,120$ & $<1,130$ & $<1,130$ \\
\hline \$96T000368 & \multirow[t]{2}{*}{$124: 9$} & Upper $1 / 2$ & $<1,120$ & $<1,120$ & $<1,120$ \\
\hline \$96T000369 & & Lower $1 / 2$ & $<1,090$ & $<1,240$ & $<1,170$ \\
\hline \$96T000511 & 128:1 & Whole & $<1,040$ & $<984$ & $<1,010$ \\
\hline
\end{tabular}


WHC-SD-WM-ER-609 Rev. 0

Table B-1. Tank 241-U-109 Analytical Results: Bromide. (2 sheets)

\begin{tabular}{|c|c|c|c|c|c|}
\hline $\begin{array}{l}\text { Samples } \\
\text { Nimanter }\end{array}$ & $\begin{array}{l}\text { Corgi } \\
\text { Segronen }\end{array}$ & $\begin{array}{l}\text { Sub } \\
\text { orgunent }\end{array}$ & Resilil & Buplicate & Sarnole. \\
\hline 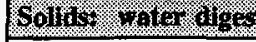 & 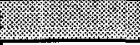 & 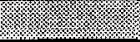 & 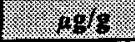 & $\sqrt{1218}$ & 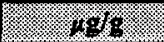 \\
\hline S96T000512 & 128:2 & Whole & $<978$ & $<1,020$ & $<999$ \\
\hline S96T000513 & $128: 3$ & Whole & $<1,460$ & $<1,520$ & $<1,490$ \\
\hline S96T000514 & \multirow[t]{2}{*}{$128: 4$} & Upper $^{1 / 2}$ & $<1,480$ & $<1,550$ & $<1,520$ \\
\hline S96T000515 & & Lower $1 / 2$ & $<474$ & $<482$ & $<478$ \\
\hline S96T000516 & $128: 5$ & Whole & 1,230 & 1,330 & 1,280 \\
\hline S96T000517 & \multirow[t]{2}{*}{$128: 6$} & Upper $1 / 2$ & $<461$ & $<460$ & $<461$ \\
\hline S96T000518 & & Lower $1 / 2$ & $<489$ & $<454$ & $<472$ \\
\hline S96T000519 & \multirow[t]{2}{*}{$128: 7$} & Upper $1 / 2$ & $<551$ & $<513$ & $<532$ \\
\hline S96T000520 & & Lower $1 / 2$ & $<485$ & $<443$ & $<464$ \\
\hline S96T000521 & \multirow[t]{2}{*}{$128: 8$} & Upper $1 / 2$ & $<966$ & $<923$ & $<945$ \\
\hline S96T000522 & & Lower $1 / 2$ & $<501$ & $<508$ & $<505$ \\
\hline S96T000523 & $128: 9$ & Whole & $<262$ & $<280$ & $<271$ \\
\hline \multicolumn{3}{|c|}{ Conpesites: rater digest } & $.19 \mathrm{gg}$ & $=08 \mathrm{~g}$ & 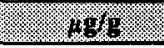 \\
\hline S96T001412 & 123 & $\mathrm{n} / \mathrm{a}$ & $<914$ & $<974$ & $<944$ \\
\hline S96T001659 & 124 & $\mathrm{n} / \mathrm{a}$ & $<1,020$ & $<928$ & $<974$ \\
\hline S96T001700 & 128 & $\mathrm{n} / \mathrm{a}$ & $<1,220$ & $<1,230$ & $<1,230$ \\
\hline \multicolumn{3}{|l|}{ Grguids? water digest } & $1.9 \mathrm{~min}$ & Hgrmi. & setni. \\
\hline S96T000280 & $124: 3$ & DL & 9,100 & 8,920 & 9,010 \\
\hline
\end{tabular}


Table B-2. Tank 241-U-109 Analytical Results: Lithium. (2 sheets)

\begin{tabular}{|c|c|c|c|c|c|}
\hline (6) & o. & (2) & 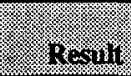 & Bungritis & . 63919 \\
\hline \multicolumn{2}{|c|}{ 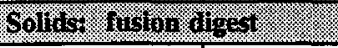 } & (2) & 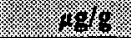 & 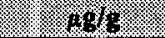 & 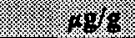 \\
\hline S96T000256 & 123:1 & Whole & $<254$ & $<213$ & $<234$ \\
\hline S96T000259 & $123: 2$ & Whole & $<251$ & $<238$ & $<245$ \\
\hline S96T000260 & \multirow[t]{2}{*}{$123: 3$} & Upper $1 / 2$ & $<190$ & $<198$ & $<194$ \\
\hline S96T000261 & & Lower $1 / 2$ & $<201$ & $<207$ & $<204$ \\
\hline \$96T000262 & $123: 4$ & Whole & $<214$ & $<228$ & $<221$ \\
\hline S96T000263 & $123: 5$ & Whole & $<199$ & $<177$ & $<188$ \\
\hline$\$ 96 \mathrm{~T} 000264$ & \multirow[t]{2}{*}{$123: 6$} & Upper $1 / 2$ & $<226$ & $<231$ & $<229$ \\
\hline S96T000265 & & Lower $1 / 2$ & $<188$ & $<181$ & $<185$ \\
\hline S96T000266 & \multirow[t]{2}{*}{$123: 7$} & Upper $1 / 2$ & $<186$ & $<181$ & $<184$ \\
\hline S96T000267 & & Lower $1 / 2$ & $<234$ & $<218$ & $<226$ \\
\hline S96T000268 & \multirow[t]{2}{*}{$123: 8$} & Upper $1 / 2$ & $<191$ & $<187$ & $<189$ \\
\hline S96T000269 & & Lower $1 / 2$ & $<181$ & $<187$ & $<184$ \\
\hline S96T000270 & \multirow[t]{3}{*}{$123: 9$} & A & $<239$ & $<210$ & $<225$ \\
\hline S96T000271 & & $\mathbf{B}$ & $<178$ & $<194$ & $<186$ \\
\hline$\$ 96 T 000272$ & & $\mathrm{C}$ & $<179$ & $<181$ & $<180$ \\
\hline S96T000344 & $124: 2$ & Whole & $<216$ & $<214$ & $<215$ \\
\hline \$96T000345 & $124: 3$ & Whole & $<205$ & $<215$ & $<210$ \\
\hline S96T000346 & $124: 4$ & Whole & $<221$ & $<210$ & $<216$ \\
\hline$\$ 96 \mathrm{~T} 000347$ & \multirow[t]{2}{*}{$124: 5$} & Upper $1 / 2$ & $<241$ & $<250$ & $<246$ \\
\hline S96T000348 & & Lower $1 / 2$ & $<210$ & $<208$ & $<209$ \\
\hline S96T000349 & \multirow[t]{2}{*}{$124: 6$} & Upper $1 / 2$ & $<195$ & $<182$ & $<189$ \\
\hline$\$ 96 \mathrm{~T} 000350$ & & Lower $1 / 2$ & $<183$ & $<186$ & $<185$ \\
\hline S96T000351 & \multirow[t]{2}{*}{$124: 7$} & Upper $1 / 2$ & $<248$ & $<224$ & $<236$ \\
\hline \$96T000352 & & Lower $1 / 2$ & $<223$ & $<204$ & $<214$ \\
\hline S96T000353 & \multirow[t]{2}{*}{$124: 8$} & Upper $1 / 2$ & $<200$ & $<189$ & $<195$ \\
\hline S96T000354 & & Lower $1 / 2$ & $<197$ & $<175$ & $<186$ \\
\hline S96T000355 & \multirow[t]{2}{*}{$124: 9$} & Upper $1 / 2$ & $<201$ & $<195$ & $<198$ \\
\hline \$96T000356 & & Lower $1 / 2$ & $<207$ & $<216$ & $<212$ \\
\hline S96T000498 & $128: 1$ & Whole & $<207$ & $<214$ & $<211$ \\
\hline
\end{tabular}




\begin{tabular}{|c|c|c|c|c|c|}
\hline $10^{\circ} t>$ & $10 \div>$ & $010^{\circ} t>$ & Td & $\mathcal{E}: \nabla Z I$ & 082000.L96S \\
\hline 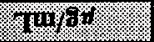 & Woff & rimfor & & & 15ame repunbu \\
\hline $88 \mathrm{I}>$ & $t 6 I>$ & $28 \mathrm{I}>$ & $\mathrm{E} / \mathrm{U}$ & $82 I$ & $669100196 S$ \\
\hline S6I $>$ & S6I > & $56 I>$ & $\mathbf{E} / \mathrm{U}$ & $\nabla Z I$ & 8S9LOOLL6S \\
\hline $002>$ & L6I $>$ & $\varepsilon 0 Z>$ & $\mathbf{E} / \mathrm{u}$ & $\varepsilon 21$ & I ItI00.196S \\
\hline SWhi: & 3ht & Shot: & & Isomo nowsin & ny sonsodoriog \\
\hline$\angle I Z>$ & $\varepsilon I Z>$ & $I 2 Z>$ & วЮЧМ & $6: 82 I$ & 0IS000I96S \\
\hline $\mathcal{E E Z}>$ & $8 E Z>$ & $\angle Z Z>$ & $z_{1}$ IOMOT & \multirow[b]{2}{*}{$8: 8 Z I$} & 60S000L96S \\
\hline$\angle O Z>$ & soz > & $80 z>$ & $z / \tau$ Iədd $\Lambda$ & & 80 S000L96S \\
\hline $202>$ & sIZ $>$ & $88 \mathrm{I}>$ & $2 / 1$ IOMOI & \multirow[b]{2}{*}{$L: 8 Z I$} & LOSO00LI96S \\
\hline$I z Z>$ & IZZ $>$ & $0 z z>$ & $z_{1}$ Iodd $\Omega$ & & 90S000L96S \\
\hline$z z z>$ & IZZ > & $\varepsilon Z Z>$ & Z/r JәMO & \multirow[b]{2}{*}{ 9:8ZI } & SOS000.L96S \\
\hline $80 z>$ & $\angle 6 \mathrm{I}>$ & $8 I Z>$ & $z_{1} \operatorname{rodd}_{n}$ & & t0S000L96S \\
\hline $\mathrm{IOZ}>$ & $961>$ & $902>$ & गๆО५М & $S: 8 Z I$ & E0SO00L96S \\
\hline $0 \mathrm{II}>$ & $\mathrm{s} 0 \mathrm{z}>$ & $\pm I Z>$ & $z / 1$ IәMO 1 & \multirow[b]{2}{*}{$t: 8 Z I$} & Z0S000L96S \\
\hline$\varepsilon z \tau>$ & $0 \varepsilon Z>$ & $9 I 2>$ & $z / 1$ Iədd $n$ & & I0S000L96S \\
\hline IEZ $>$ & IEZ > & $0 \varepsilon Z>$ & ग०पМ & $\varepsilon: 8 Z \mathrm{I}$ & 00S000I96S \\
\hline $102>$ & $\angle O Z>$ & $66 I>$ & गОчМ & $Z: 8 Z I$ & $66+000.196 \mathrm{~S}$ \\
\hline 8) & Bow: & 6 & & \multicolumn{2}{|c|}{ 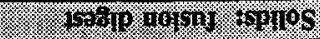 } \\
\hline ingul & 9ivoling & 198\% & 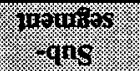 & 1001060\% & 196inims. \\
\hline
\end{tabular}

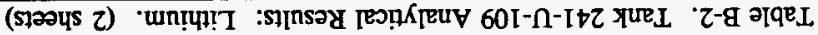


WHC-SD-WM-ER-609 Rev. 0

This page intentionally left blank. 
WHC-SD-WM-ER-609 Rev. 0

APPENDIX C

ANALYTICAL RESULTS FROM HISTORICAL SAMPLING EVENTS FOR SINGLE-SHELL TANK 241-U-109 
WHC-SD-WM-ER-609 Rev. 0

This page intentionally left blank. 


\section{C.0 ANALYTICAL RESULTS FROM HISTORICAL SAMPLING EVENTS OF SINGLE-SHELL TANK 21-U-109}

\section{C.1 INTRODUCTION}

Appendix C presents analytical results from the 1975 historical sampling event for tank 241-U-109. A description of this event was provided in Section 3.4. As explained in that section, because of the active process history of the tank, these results are not representative of the current tank contents. Thus, these data are presented for information only. Because of the lack of proper QA/QC procedures, the data presented in these tables may not be reliable and should be used with caution. Further detail regarding this sampling event can be found in the source document (Horton 1975a). 
WHC-SD-WM-ER-609 Rev. 0

Table C-1. 1975 Supernatant Sample from Tank 241-U-109.,2

\begin{tabular}{|c|c|c|}
\hline 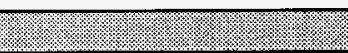 & Imosichl bath: & 1) \\
\hline Conponient & 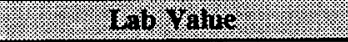 & Silo vinis: \\
\hline Density & 1.24 & $\mathrm{~g} / \mathrm{mL}$ \\
\hline Water content & 63.3 & Weight percent \\
\hline কיয & Chemilot Bats & 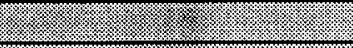 \\
\hline : Canpoliger. & Molning & Weigh rerment: \\
\hline $\mathrm{Na}_{2} \mathrm{CO}_{3}$ & 0.243 & 2.1 \\
\hline $\mathrm{NaNO}_{2}$ & 0.628 & 3.5 \\
\hline $\mathrm{NaNO}_{3}$ & 3.08 & 21.1 \\
\hline $\mathrm{NaOH}$ & 1.31 & 2.5 \\
\hline $\mathrm{NaAlO}_{2}$ & 0.342 & 2.3 \\
\hline $\mathrm{Na}_{3} \mathrm{PO}_{4}$ & 0.0476 & 0.6 \\
\hline $\mathrm{Si}$ & 0.0111 & 2.5 \\
\hline $\mathrm{Fe}$ & $8.24 \mathrm{E}-04$ & $<1.0$ \\
\hline$\overline{\mathrm{Mg}}$ & $4.13 \mathrm{E}-04$ & $<1.0$ \\
\hline $\mathrm{Mn}$ & $8.55 \mathrm{E}-04$ & 0.3 \\
\hline $\mathrm{Pu}$ & $5.86 \mathrm{E}-05$ & $n / a$ \\
\hline 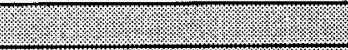 & Tadiological bata & 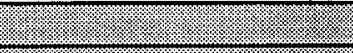 \\
\hline Component: & Lab Yalue & Tio Int \\
\hline${ }^{137} \mathrm{Cs}$ & 75.42 & $\mu \mathrm{Ci} / \mathrm{L}$ \\
\hline${ }^{89 / 90} \mathrm{Sr}$ & 3,150 & $\mu \mathrm{Ci} / \mathrm{L}$ \\
\hline
\end{tabular}

Note:

'Horton (1975a)

${ }^{2}$ Because of the lack of proper QA/QC procedures, the data presented in these tables may not be reliable and should be used with caution. 


\section{WHC-SD-WM-ER-609 Rev. 0}

Table C-2. 1975 Sludge Sample from Tank 241-U-109.1,2

\begin{tabular}{|c|c|c|}
\hline 1. & 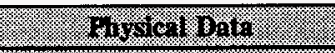 & 28 \\
\hline Compondin & 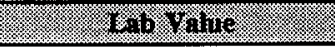 & Tho W11 \\
\hline Bulk density & 1.05 & $\mathrm{~g} / \mathrm{mL}$ \\
\hline Particle density & 2.73 & $\mathrm{~g} / \mathrm{mL}$ \\
\hline 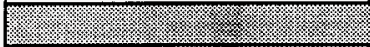 & obeniol 802 & 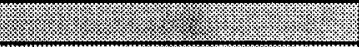 \\
\hline 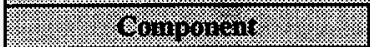 & 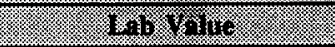 & 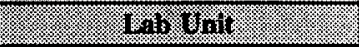 \\
\hline $\mathrm{H}_{2} \mathrm{O}$ & 36.7 & Weight percent \\
\hline $\mathrm{Al}_{2} \mathrm{O}_{3}$ & 17.4 & Weight percent \\
\hline $\mathrm{FeOOH}$ & 10 & Weight percent \\
\hline $\mathrm{Na}_{2} \mathrm{CO}_{3}$ & 2.4 & Weight percent \\
\hline $\mathrm{NaNO}_{2}$ & 0.8 & Weight percent \\
\hline $\mathrm{NaNO}_{3}$ & 4 & Weight percent \\
\hline $\mathrm{NaOH}$ & 1 & Weight percent \\
\hline $\mathrm{SiO}_{3}$ & 0.7 & Weight percent \\
\hline $\mathrm{Na}_{3} \mathrm{PO}_{4}$ & 21.9 & Weight percent \\
\hline $\mathbf{M g}$ & 0.03 & Weight percent \\
\hline $\mathrm{Mn}$ & 0.1 & Weight percent \\
\hline $\mathrm{Pu}$ & 63.3 & $\mu \mathrm{g} / \mathrm{g}$ \\
\hline (1) & Radiological Bata & 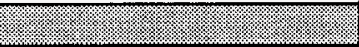 \\
\hline Conporent: & Iab Varie:-s: & (19il Jnit \\
\hline${ }^{137} \mathrm{Cs}$ & 325.5 & $\mu \mathrm{Ci} / \mathrm{g}$ \\
\hline${ }^{8990} \mathrm{Sr}$ & 128.6 & $\mu \mathrm{Ci} / \mathrm{g}$ \\
\hline
\end{tabular}

Note:

'Horton (1975a)

${ }^{2}$ Because of the lack of proper $\mathrm{QA} / \mathrm{QC}$ procedures, the data presented in these tables may not be reliable and should be used with caution. 
WHC-SD-WM-ER-609 Rev. 0

This page intentionally left blank. 